F2nwmpa

1996 (

1996 (n)
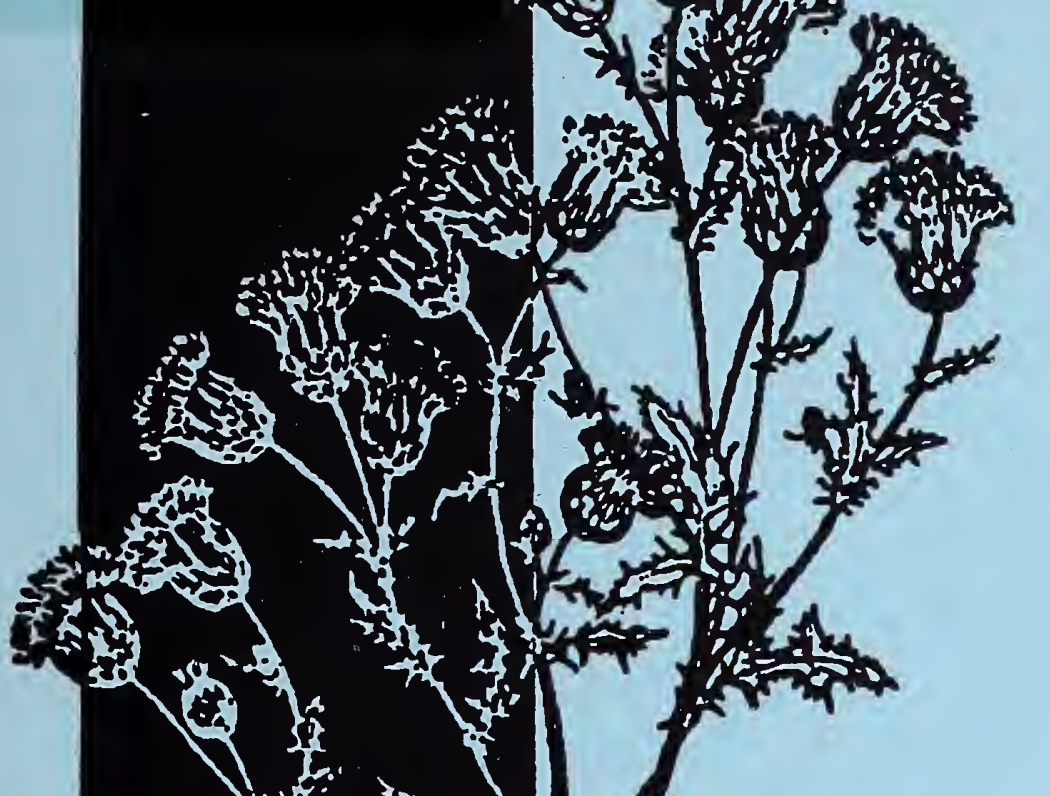

w

$+2$

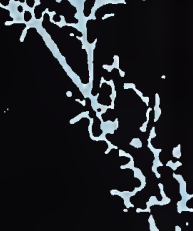

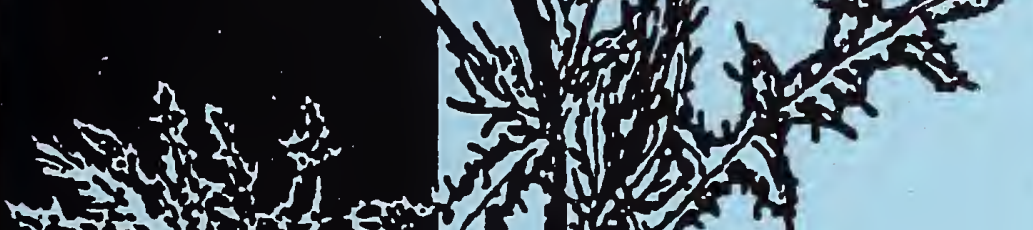

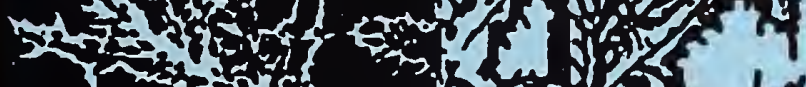

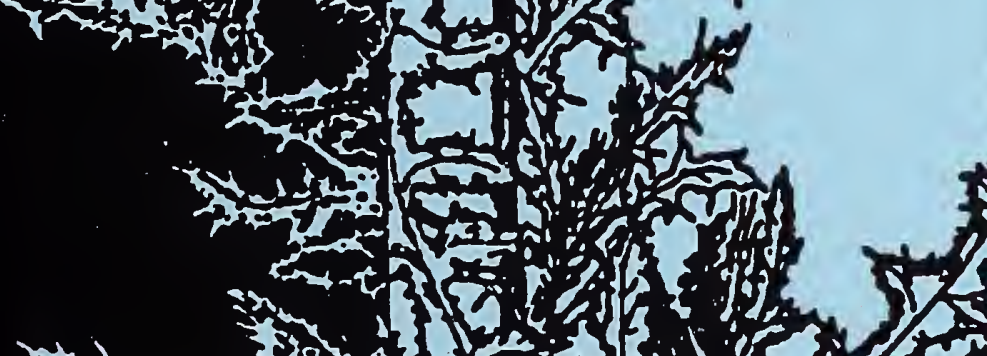

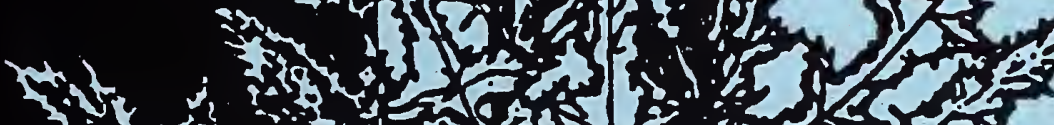

- no rut +2 th

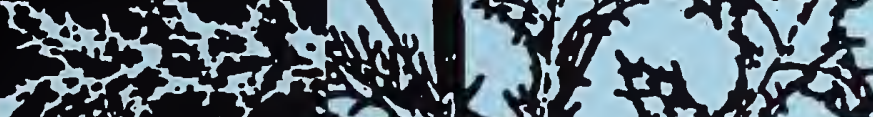
(1)

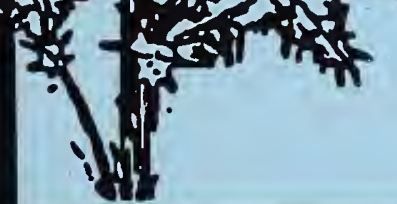

\section{DRAFT}

August - 1996

\section{Noxious Weed}

Management Plan and

\section{Environmental Assessment}

\section{crist SMontana Tish.

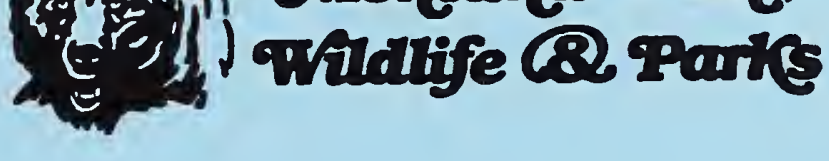 \\ Region 7}

STATE DOCUMENTS COLLECTION

\section{FFB 112002}

MONTANA STATE LIBRARY 1515 E. 6th AVE.
HELENA, MONTANA 59620 


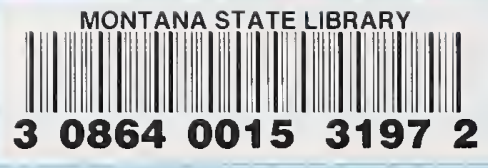




\title{
Noxious Weed
}

Management Plan

Montana Fish, Wildlife \& Parks Region Seven

\author{
Prepared by \\ State Parks Division \\ P. O. Box 1630 \\ Miles City, MT 59301
}

August 1996 



\section{TABLE OF CONTENTS}

Page

LIST OF TABLES $\ldots \ldots \ldots \ldots \ldots \ldots \ldots \ldots \ldots \ldots \ldots \ldots \ldots \ldots$ iv

LIST OF FIGURES $\ldots \ldots \ldots \ldots \ldots \ldots \ldots \ldots \ldots \ldots \ldots \ldots \ldots \ldots$

1.0 INTRODUCTION $\ldots \ldots \ldots \ldots \ldots \ldots \ldots \ldots \ldots \ldots \ldots \ldots \ldots \ldots$

1.1 Noxious Weed Management Program Guidance and Objectives ....... 1

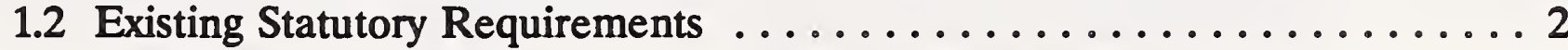

1.3 Overview and Setting $\ldots \ldots \ldots \ldots \ldots \ldots \ldots \ldots \ldots \ldots \ldots \ldots \ldots \ldots \ldots \ldots \ldots$

1.3.1 Property Groups ........................ 4

2.0 NOXIOUS WEED MANAGEMENT STRATEGIES . . . . . . . . . . . . 14

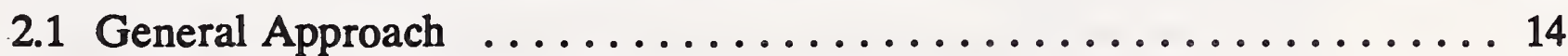

2.2 Conceptual Framework to Prioritize Activities . . . . . . . . . . . 14

2.2.1 Species Specific Directives ................... 14

2.2.2 Location and Population Size ................ 15

2.2.3 Special Management Zones .................. 16

2.3 Treatment Methods and Techniques ................. 20

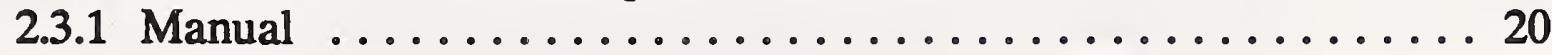

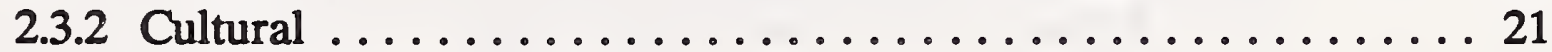

2.3 .3 Biological ........................... 22

2.3 .4 Chemical ............................ 23

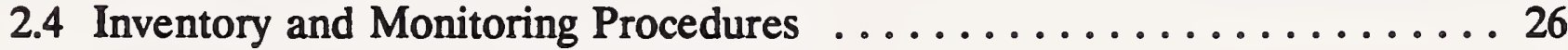

2.5 Assignment of Plan Responsibilities . . . . . . . . . . . . . . 26

2.5.1 Oversight of Plan Implementation $\ldots \ldots \ldots \ldots \ldots \ldots$

2.5.2 DFWP R-7 Applicators, Licenses and Record Keeping . . . . . 26

2.5 .3 Contracted Services . . . . . . . . . . . . . . . 27

2.6 Other Subjects of Concern ...................... 31

2.6.1 Threatened, Endangered, and Sensitive Species ........ 31

2.6.2 Herbicide Labels . . . . . . . . . . . . . . . . . . 31

3.0 PROPERTY GROUP TREATMENT PLANS $\ldots \ldots \ldots \ldots \ldots \ldots \ldots \ldots \ldots \ldots$

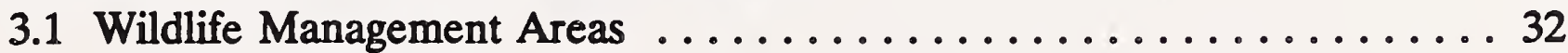

3.1 .1 Introduction . . . . . . . . . . . . . . . . . 32

3.1.2 Former Glacier Park Co. Parcels ................. 34

3.1.3 F Island and Fort Keogh Islands . . . . . . . . . . 36

3.1 .4 Elk Island. . . . . . . . . . . . . . . . . . . . 37

3.1 .5 Isaac Homestead. . . . . . . . . . . . . . . . . . 39

3.1 .6 Seven Sisters . . . . . . . . . . . . . . . . . 41 


\section{TABLE OF CONTENTS, continued}

Page

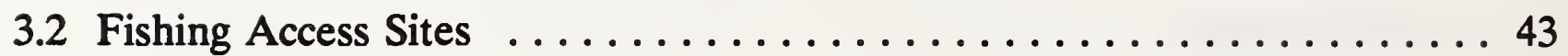

3.2 .1 Introduction ....................... 43

3.2.2 Yellowstone River Drainage ................ 45

3.2.3 Tongue River Drainage $\ldots \ldots \ldots \ldots \ldots \ldots \ldots \ldots \ldots \ldots$

3.2 .4 Powder River Drainage . . . . . . . . . . . . . . . 50

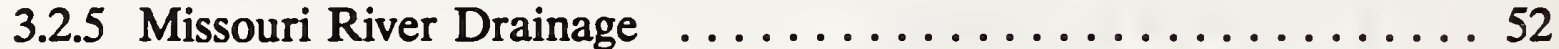

3.2 .6 Ponds and Lakes .................... 53

3.3 State Parks and Administrative Sites ................ 55

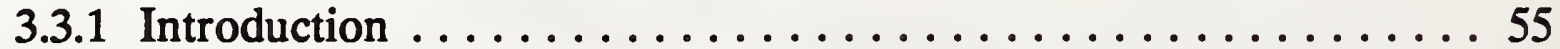

3.3 .2 Makoshika ....................... 57

3.3.3 Rosebud Battlefield ................... 60

3.3 .4 Medicine Rocks. . . . . . . . . . . . . . . . 62

3.3 .5 Pirogue Island. . . . . . . . . . . . . . . . 64

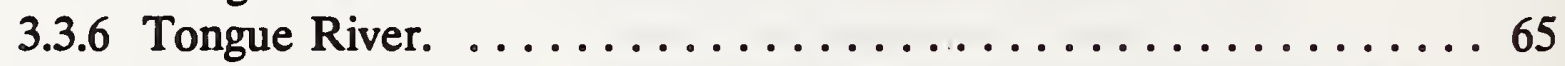

3.3.7 Hell Creek. . . . . . . . . . . . . . . . . . 68

3.3.8 Miles City Fish Hatchery $\ldots \ldots \ldots \ldots \ldots \ldots \ldots \ldots \ldots$

3.3.9 Region Seven Administrative Sites . . . . . . . . . . 71

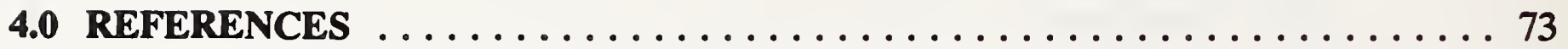




\section{TABLE OF CONTENTS, continued}

\section{APPENDICES}

Appendix A County Noxious Weed Control Act of 1979

Appendix B Synopsis of Noxious Weed Species

Appendix C Laws and Policies Relating to the Management of Noxious Weeds

Appendix D Biological Control Agents Available in Montana and Those Released on Department of Fish, Wildlife and Parks Properties

Appendix E Herbicide Emergency Response Plan

Appendix F Sensitive Species Occurring in the Vicinity of Montana Department of Fish, Wildlife and Parks Region 7 Properties

Appendix G Herbicides Proposed for Use on Department of Fish, Wildlife and Parks Region 7 Properties

Appendix $\mathbf{H} \quad$ Herbicide Label Instructions and Safety Precautions 


\section{Digitized by the Internet Archive in 2016}




\section{LIST OF TABLES}

Page

Table 1. Noxious weed species present and status on Department of Fish, Wildlife and Parks Wildlife Management Areas in Region 7

Table 2. Noxious weed species present and status on Department of Fish, Wildlife and Parks Fishing Access Sites in Region 7 by

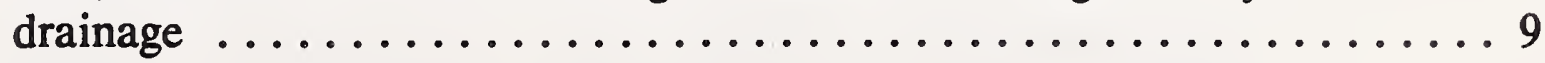

Table 3. Noxious weed species present and status on Department of Fish, Wildlife and Parks State Parks in Region 7 ........... 12

Table 4. Soil index values, risk classes, and soil descriptions used to identify groundwater areas sensitive to chemical contamination 



\section{LIST OF FIGURES}

Page

Figure 1 Properties owned by or leased to Montana Department of Fish, Wildlife and Parks in Region 7 ................... 5

Figure 2 Assignment of Plan Responsibilities, Department of Fish, Wildlife and Parks in Region 7 ............... 28-30

Figure 3 Wildlife Management Areas (WMA's) administered by Montana Department of Fish, Wildlife and Parks in Region

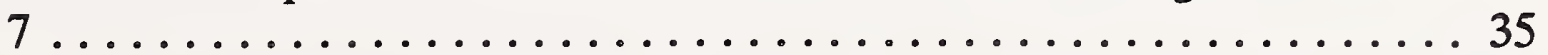

Figure 4 Fishing Access Sites administered by Montana Department of Fish, Wildlife and Parks in Region $7 \ldots \ldots \ldots \ldots \ldots \ldots$

Figure 5 State Parks administered by Montana Department of Fish, Wildlife and Parks in Region $7 \ldots \ldots \ldots \ldots \ldots \ldots \ldots$ 



\subsection{INTRODUCTION}

\subsection{Noxious Weed Management Program Guidance and Objectives}

The Montana Department of Fish, Wildlife and Parks (DFWP) recently adopted its Vision document which describes the direction in which the Department is heading and how the goals articulated within that document will be reached (DFWP 1992). The basic Mission of the agency is:

"to provide for the stewardship of the fish, wildlife, parks, and recreational resources of Montana, while contributing to the quality of life for present and future generations."

A key element of all DFWP programs is to consider how policies and programs affect adjacent lands, and in turn, how adjacent lands affect DFWP properties. This perspective is rooted in a strong commitment to public involvement in management decisions. In 1983, the Department adopted a Noxious Weed Control Program (NWMP) for lands managed by the agency (DFWP 1983). The objective of the program is:

"to prevent, to the greatest extent possible, the reproduction, proliferation, and distribution of agriculturally undesirable plant species throughout department lands or from department lands onto adjacent lands."

Overall direction for regional implementation of the NWMP is provided by the Vision document and statutory requirements based in state law and local ordinances. The purpose of DFWP Region 7's Noxious Weed Management Plan (Plan) is to describe the strategies and management actions necessary for the prevention, stabilization, control, or eradication of noxious weed populations on DFWP lands.

Management actions must be appropriate to land classification and use, and must satisfy DFWP's legal mandate to serve as steward of specific natural and recreational lands within southeastern Montana. This Plan outlines an integrated approach to noxious weed management based on site conditions by employing a variety of methods and techniques, including manual, cultural, biological, and chemical treatments will be applied. More specifically, the objectives of the Plan are to:

- Meet legal requirements (including the County Noxious Weed Control act and the Montana Environmental Policy Act) to manage plants declared as noxious weeds by the State, and by the Big Horn, Carter, Custer, Dawson, Fallon, Garfield, Prairie, Richland, Rosebud and Treasure county weed boards.

- Develop and implement an integrated approach to noxious weed management and a strategy to prioritize treatment areas. 
- Attempt to contain, reduce or eradicate noxious weed populations, depending on the location and density and to discourage the introduction of new noxious weed species.

- Work cooperatively with adjacent landowners and the County Weed Boards to enable consistent and sound weed treatment efforts.

- Conduct treatments in an ecologically responsible manner to protect and maintain fish, wildlife, vegetation, and recreation resources and to ensure human health and safety.

- Involve the public in the planning process.

- Update the plan every six years.

\subsection{Existing Statutory Requirements}

The State of Montana has recognized the damaging effects of noxious weeds in laws and regulations. The County Noxious Weed Control Act of 1979 (MCA 7-22-21-1 et seq., as amended 1991, Appendix A) defines "noxious weeds" as "any exotic plant species established or that may be introduced in the state which may render land unfit for agriculture, forestry, livestock, wildlife, or other beneficial uses or that may harm native plant communities..." Administered at the county level, this law requires counties to develop weed control districts to plan and implement a weed control program. County commissioners appoint a district weed board which is responsible for the administration and enforcement of the district's noxious weed control efforts. The law provides for the promulgation of rules to list statewide noxious weeds and, it allows for county-wide listing of additional species. In addition, this law also gives specific direction to counties for cooperation with state and federal-aid programs. Furthermore, the law states that "it is unlawful for any person to permit any noxious weed to propagate or go to seed on his [or her] land" (7-22-2115) and, it encourages landowners to file weed control plans (7-22-2116).

This Plan has also been prepared in anticipation of the encouragement state agency weed control efforts will receive from the 1995 Montana Legislature's House Bill \#395 (MCA 722-2151). The measure in a broad sense, requires state agencies to enter into cooperative agreements with local weed district boards for the purpose of integrated noxious weed management on state lands. The measure also requires agencies to formulate 6 year weed management plans for lands administered by each agency. The DFWP R-7 Weed Management Plan will serve as the "umbrella" document for R-7's cooperative agreements and 6 year plans under (MCA 7-22-2151). This Plan and accompanying Environmental Assessment (EA), will provide the guidelines and objectives for weed control management, including treatments, selected in the 6 year plans. 
The weed species declared as noxious by the State of Montana (through the Department of Agriculture) and by the individual county weed boards within the administrative boundaries of DFWP Region 7 are listed in Appendix B. The treatment of noxious weeds, particularly through the use of herbicides, is also subject to other state and federal laws as well as the policies and programs of other agencies. These are summarized in Appendix C.

\subsection{Overview and Setting}

Exotic (non-native) "weedy" plants have been noted in Montana throughout this century. DFWP draws a distinction between "weedy" species and "noxious" species. DFWP recognizes the value of some weed species to wildlife as food and/or cover. For example, some "weedy" species in the composite family (e.g. dandelion, Prickly lettuce, and Goat's beard) are important components of upland game bird summer diets. As declared in law, "noxious" weeds are those non-native species which are very aggressive and successful competitors for nutrients, moisture, and space. In the past few decades, some noxious weed species have become significant components of local vegetation communities, actually dominating some sites. Noxious weeds may reduce vegetation biodiversity and may limit the diversity of wildlife. Native vegetation species are also more desirable for providing erosion control and visual aesthetics.

Noxious weeds occur on many sites currently administered by DFWP, although most invasions occurred prior to DFWP acquisition. The number of species and the total coverage vary considerably by site and the nature of land use. Important factors influencing noxious weed establishment include proximity to water, previous overgrazing practices, human activities, site disturbance and seed dispersal -- the latter two of which can be aggravated by road access.

This Plan considers the treatment and management of noxious weeds on 42 separate properties totaling approximately 18,000 acres owned by or leased to DFWP Region 7 within Big Horn, Carter, Custer, Dawson, Fallon, Garfield, Prairie, Richland, Rosebud and Treasure Counties (DFWP 1994). Figure 1 illustrates the location of these properties. In certain instances, on properties leased to or leased out by the department, weed control responsibilities have been retained by the private or public lessee or leaseholder. This Plan will note the location of such properties, but will not address noxious weed management as individual leases may specifically address the topic. Also, this Plan does not address Block Management lands or Fishing Pond and Reservoir Program agreements with private and public owners, as weed control responsibilities are retained by those entities. Chapter 2.0 identifies strategies to prioritize treatment activities and reviews methods and techniques of noxious weed treatments. Chapter 3.0 outlines specific weed management programs for the groups of properties outlined below. 


\subsubsection{Property Groups}

Lands administered by DFWP can be classified according to the Department Land Classification Manual (DFWP 1988) based on management, uses and funding sources.

The Wildlife Division oversees the Wildlife Management Areas (WMA's) and Wildlife Habitat Protection Areas (WHPA's). These areas are set aside primarily to preserve wildlife habitat and secondarily to provide opportunities for both consumptive and nonconsumptive outdoor recreation. Within Region 7, there are 8 WMA's and 2 WHPA's totaling $3,208.3$ acres.

The Fisheries Division oversees the management of State Fish Hatcheries. Weed control responsibilities are carried out by personnel at each unit. There is one Fish hatchery in Region 7 totalling 245.6 acres.

The Parks Division manages State Parks (SP's) classified as either: natural, historic, or recreational. SP's are established for the purpose of conserving the scenic, historic, archaeologic, scientific and recreational resources of the state and providing for their use and enjoyment, thereby contributing to the cultural, recreational and economic life of the people and their health (23-1-101 MCA). There are 6 SP's totaling 13,316.5 acres in Region 7.

The Parks Division also oversees the management of Fishing Access Areas and/or Sites (for purposes of this report, all will be referred to as FAS's). The primary goal of the FAS system in Montana, is to provide the public with access to high-quality fishing opportunities. FAS's also provide secondary recreational opportunities, including picnicking, camping, and wildlife viewing opportunities among others. There are 23 access sites in Region 7, totalling 1,120 acres.

The Region 7 headquarters complex is comprised of two sites totalling 7.6 acres. The Parks Division oversees the weed control activities on these sites.

Because of differences in land use, site disturbance, and the degree of noxious weed establishment, these lands have different opportunities and constraints for the management of noxious weeds. Therefore, this Plan will examine groups of properties where similarities merit and will direct appropriate management strategies accordingly. Site specific management strategies will be outlined for property groups, while recognizing that some deviations will occur. These differences will be highlighted and addressed more specifically in Part 3.0 of this document. The following discussion describes the groupings in general, whereas Tables 1, 2 and 3 outline the property groups, list discrete properties by name, and report the findings of the most recent noxious weed inventories conducted on the majority of sites during spring, 1993. 


\section{Master Legend for Department Property}

Fishing Access Sites

1. Diamond Willow

2. Sidney Bridge

3. Gartside Dam

4. Intake

5. Hollecker Pond

6. Johnson Reservoir

7. Fallon Bridge

8. Powder River Depot

9. Bonfield

10. Kinsey Bridge

11. Roche Juane
12. Far West

13. East Rosebud

14. West Rosebud

15. Amelia Island

16. Myers Bridge

17. South Sandstone

18. Twelve Mile Dam

19. Broadus Bridge

20. Little Powder River

21. Rush Hall Reservoir

22. Culbertson Bridge

Key to the Wildlife Management Areas

1. F Island

2. Seven Sisters

3. Elk Island

4. War Dance

5. Three Mile Island
6. Badlands

7. Fort Keogh Islands (2)

8. Howard Valley

9. Sanders

10. Issac Homestead

\section{State Parks and Administrative Sites}

1. Makoshika

2. Medicine Rocks

3. Pirogue Island

4. Miles City Fish Hatchery \&

Region Seven Headquarters
5. Hell Creek

6. Rosebud Battlefield

7. Tongue River Reservoir 
Table 1. Noxious weed species present and status on Department of Fish, Wildlife and Parks (DFWP) Wildlife Management Areas in Region 7.

\begin{tabular}{|c|c|c|c|c|}
\hline $\begin{array}{l}\text { MAP KEY } \\
\text { NUMBER }\end{array}$ & $\begin{array}{l}\text { DFWP PROPERTY } \\
\text { NAME and ACREAGE }\end{array}$ & $\begin{array}{l}\text { WEED SPECIES } \\
\text { PRESENT }\end{array}$ & $\begin{array}{l}\text { WEED } \\
\text { SIZE }^{1}\end{array}$ & $\begin{array}{l}\text { STATUS } \\
\text { DENSITY }^{2}\end{array}$ \\
\hline 6 & Badlands (2.3) & none & & \\
\hline \multirow[t]{4}{*}{3} & \multirow{4}{*}{$\begin{array}{l}\text { Elk Island } \\
(1,208.5)\end{array}$} & Canada thistle & 3 & LDB \\
\hline & & $\begin{array}{l}\text { Russian } \\
\text { knapweed }\end{array}$ & 18 & MD \\
\hline & & Leafy spurge & $1 / 8$ & LDA \\
\hline & & Field bindweed & 3 & LDA \\
\hline 1 & F Island $(94.7)$ & none & & \\
\hline 7 & $\begin{array}{l}\text { Fort Keogh Islands } \\
\text { (79) }\end{array}$ & none & & \\
\hline 8 & Howard Valley $(.18)$ & none & & \\
\hline \multirow[t]{4}{*}{10} & \multirow[t]{4}{*}{$\begin{array}{c}\text { Issac Homestead } \\
(1,168.5)\end{array}$} & $\begin{array}{c}\text { Russian } \\
\text { knapweed }\end{array}$ & 2 & LDB \\
\hline & & Canada thistle & 5 & MD \\
\hline & & Poison hemlock & $1 / 64$ & LDA \\
\hline & & $\begin{array}{l}\text { other weed } \\
\text { species }\end{array}$ & 14 & LDB \\
\hline 9 & Sanders (.26) & none & & \\
\hline \multirow[t]{3}{*}{2} & \multirow[t]{3}{*}{ Seven Sisters (635.3) } & Leafy spurge & $1 / 16$ & LDA \\
\hline & & Canada thistle & 2 & LDB \\
\hline & & Field bindweed & 2 & LDA \\
\hline 5 & $\begin{array}{l}\text { Three Mile Island } \\
(8.1)\end{array}$ & none & & \\
\hline 4 & War Dance (11.5) & none & & \\
\hline
\end{tabular}

Size - page 8

Density - page 8 
1 SIZE: total acres or partial acres for each species, respectively:
1 acre $=43,560 \mathrm{ft}^{2}\left(200^{\prime} \times 200^{\prime}\right)$
$1 / 2$ acre $=21,780 \mathrm{ft}^{2}$
$1 / 4$ acre $=10,890 \mathrm{ft}^{2}\left(100^{\prime} \times 100^{\prime}\right)$
$1 / 16$ acre $=2,722 \mathrm{ft}^{2}\left(50^{\prime} \times 50^{\prime}\right)$
$1 / 8$ acre $=5,445 \mathrm{ft}^{2}$
$1 / 32$ acre $=1,361 \mathrm{ft}^{2}$
$1 / 64$ acre $=680 \mathrm{ft}^{2}\left(25^{\prime} \times 25^{\prime}\right)$
$<1 / 64$ acre estimation in square feet

2 DENSITY: number of weed stems in the population, respectively:

$V L D:$ very low density--one or a few individual plants, accounting for a very small proportion of the vegetative ground cover; native species well represented

LDA: low density-A --individual plants clumped in small areas, accounting for a small proportion of the vegetative ground cover; native species well represented

LDB: low density - B -- individual plants scattered throughout site, accounting for a small proportion of the vegetative ground cover; native species well represented

MD: moderate density --individual plants numerous, accounting for a moderate proportion of the vegetative ground cover; native species present

HD: high density --individual plants abundant, accounting for a high proportion of the ground cover; native species present but not well represented

VHD: very high density --individual plants very abundant,accounting for almost all of the vegetative ground cover; native species almost absent 
Table 2. Noxious weed species present and status on Department of Fish, Wildlife and Parks (DFWP) Fishing Access Sites in Region 7, by drainage.

\begin{tabular}{|c|c|c|c|c|}
\hline $\begin{array}{l}\text { MAP KEY } \\
\text { NUMBER }\end{array}$ & $\begin{array}{l}\text { DFWP PROPERTY } \\
\text { NAME and ACREAGE }\end{array}$ & $\begin{array}{l}\text { WEED SPECIES } \\
\text { PRESENT }\end{array}$ & \multicolumn{2}{|c|}{$\begin{array}{l}\text { WEED STATUS } \\
\text { SIZE }^{1} \text { DENSITY }^{2}\end{array}$} \\
\hline \multicolumn{5}{|c|}{ YELLOWSTONE RIVER DRAINAGE } \\
\hline \multirow[t]{3}{*}{16} & \multirow[t]{3}{*}{ Meyer's Bridge (15) } & $\begin{array}{c}\text { Russian } \\
\text { knapweed }\end{array}$ & $1 / 8$ & LDA \\
\hline & & Canada thistle & $1 / 4$ & LDA \\
\hline & & $\begin{array}{l}\text { other weed } \\
\text { species }\end{array}$ & $1 / 4$ & LDA \\
\hline 15 & $\begin{array}{c}\text { Amelia Island } \\
(238.8) \\
\end{array}$ & $\begin{array}{c}\text { other weed } \\
\text { species }\end{array}$ & $1 / 4$ & LDA \\
\hline \multirow[t]{2}{*}{14} & \multirow[t]{2}{*}{ Rosebud, West (8.6) } & Canada thistle & $1 / 4$ & MD \\
\hline & & $\begin{array}{c}\text { Russian } \\
\text { knapweed }\end{array}$ & $1 / 64$ & VLD \\
\hline \multirow[t]{2}{*}{13} & \multirow[t]{2}{*}{ Rosebud, East (29) } & Canada thistle & $1 / 64$ & LDA \\
\hline & & $\begin{array}{l}\text { other weed } \\
\text { species }\end{array}$ & .5 & LDA \\
\hline 12 & Far West (32.8) & $\begin{array}{l}\text { other weed } \\
\text { species }\end{array}$ & $1 / 64$ & VLD \\
\hline 11 & Roche Juane (1) & $\begin{array}{l}\text { other weed } \\
\text { species }\end{array}$ & $1 / 16$ & LDA \\
\hline \multirow[t]{4}{*}{10} & \multirow[t]{4}{*}{ Kinsey Bridge (27.7) } & $\begin{array}{c}\text { purple } \\
\text { loosestrife }\end{array}$ & $1 / 4$ & MD \\
\hline & & Field bindweed & $1 / 16$ & LDA \\
\hline & & Leafy spurge & $1 / 16$ & LDB \\
\hline & & $\begin{array}{l}\text { other weed } \\
\text { species }\end{array}$ & $1 / 2$ & LDA \\
\hline
\end{tabular}

1 Size - page 8

2 Density - page 8 
Table 2. (cont.)

\begin{tabular}{|c|c|c|c|c|}
\hline $\begin{array}{c}\text { MAP KEY } \\
\text { NUMBER }\end{array}$ & $\begin{array}{c}\text { DFWP PROPERTY } \\
\text { NAME and ACREAGE }\end{array}$ & $\begin{array}{c}\text { WEED SPECIES } \\
\text { PRESENT }\end{array}$ & $\begin{array}{c}\text { WEED SPECIES } \\
\text { SIZE }^{1}\end{array}$ \\
DENSITY
\end{tabular}

1 Size - page 8

2 Density - page 8 
Table 2. (cont.)

\begin{tabular}{|c|c|c|c|c|}
\hline $\begin{array}{l}\text { MAP KEY } \\
\text { NUMBER }\end{array}$ & $\begin{array}{l}\text { DFWP PROPERTY } \\
\text { NAME and ACREAGE }\end{array}$ & $\begin{array}{c}\text { WEED SPECIES } \\
\text { PRESENT }\end{array}$ & $\begin{array}{l}\text { WEED } \\
\text { SIZE }^{1}\end{array}$ & $\begin{array}{l}\text { SPECIES } \\
\text { DENSITY }^{2}\end{array}$ \\
\hline \multicolumn{5}{|c|}{ PONDS AND RESERVOIR'S } \\
\hline 3 & Gartside Dam (160) & Canada thistle & 1 & MD \\
\hline 5 & $\begin{array}{c}\text { Hollecker Pond (24.4) } \\
\text { leased owner } \\
\text { responsible for } \\
\text { weed control }\end{array}$ & Canada thistle & $1 / 4$ & VLD \\
\hline \multirow[t]{2}{*}{6} & \multirow[t]{2}{*}{$\begin{array}{l}\text { Johnson Reservoir } \\
\qquad(60)\end{array}$} & $\begin{array}{c}\text { other weed } \\
\text { species }\end{array}$ & $1 / 16$ & LDA \\
\hline & & Canada thistle & 1 & LDA \\
\hline 21 & $\begin{array}{c}\text { Rush Hall Reservoir } \\
\text { (24.8) } \\
\text { leased, owner } \\
\text { responsible for } \\
\text { for weed control } \\
\end{array}$ & \multicolumn{3}{|c|}{$\begin{array}{l}\text { Leafy spurge } \\
\text { Canada thistle }\end{array}$} \\
\hline \multirow[t]{3}{*}{17} & \multirow{3}{*}{$\begin{array}{c}\text { South Sandstone } \\
\text { Reservoir } \\
(360)\end{array}$} & Canada thistle & $1 / 32$ & LDA \\
\hline & & Field bindweed & $1 / 32$ & LDA \\
\hline & & $\begin{array}{c}\text { Spotted } \\
\text { knapweed }\end{array}$ & $X<1 / 64$ & VLD \\
\hline
\end{tabular}

1 Size - page 8

2 Density - page 8 
Table 3

Noxious weed species present and status on Department of Fish, Wildlife and Parks (DFWP) State Parks in Region 7.

\begin{tabular}{|c|c|c|c|c|}
\hline \multirow{3}{*}{$\begin{array}{l}\text { MAP KEY } \\
\text { NUMBER } \\
5\end{array}$} & \multirow{3}{*}{$\begin{array}{c}\text { DFWP PROPERTY } \\
\text { NAME and ACREAGE } \\
\text { Hell Creek (260) }\end{array}$} & \multirow{2}{*}{$\begin{array}{c}\text { WEED SPECIES } \\
\text { PRESENT } \\
\text { Canada thistle } \\
\end{array}$} & \multicolumn{2}{|c|}{$\begin{array}{r}\text { WEED SPECIES } \\
\text { SIZE }^{1} \text { DENSITY }^{2} \\
\end{array}$} \\
\hline & & & $1 / 4$ & HD \\
\hline & & $\begin{array}{l}\text { other weed } \\
\text { species }\end{array}$ & $1 / 16$ & LDA \\
\hline \multirow[t]{3}{*}{1} & \multirow[t]{3}{*}{ Makoshika (8832.4) } & Leafy spurge & 15 & MD \\
\hline & & Canada thistle & 1 & MD \\
\hline & & $\begin{array}{c}\text { other weed } \\
\text { species }\end{array}$ & 12 & LDA \\
\hline \multirow[t]{2}{*}{2} & \multirow{2}{*}{$\begin{array}{l}\text { Medicine Rocks } \\
\text { (320) }\end{array}$} & Canada thistle & $1 / 4$ & MD \\
\hline & & $\begin{array}{c}\text { other weed } \\
\text { species }\end{array}$ & $1 / 4$ & LDA \\
\hline \multirow[t]{3}{*}{3} & \multirow{3}{*}{$\begin{array}{l}\text { Pirogue Island } \\
\quad(210.3)\end{array}$} & Leafy spurge & 5 & MD \\
\hline & & Canada thistle & 2 & LDA \\
\hline & & $\begin{array}{l}\text { other weed } \\
\text { species }\end{array}$ & .5 & LDB \\
\hline \multirow[t]{5}{*}{6} & \multirow[t]{5}{*}{$\begin{array}{c}\text { Rosebud Battlefield } \\
\text { (3052) }\end{array}$} & $\begin{array}{c}\text { Spotted } \\
\text { knapweed }\end{array}$ & $1 / 8$ & LDB \\
\hline & & $\begin{array}{c}\text { Dalmatian } \\
\text { toadflax }\end{array}$ & $1 / 16$ & LDA \\
\hline & & Common burdock & 30 & LDA \\
\hline & & Canada thistle & 30 & LDB \\
\hline & & $\begin{array}{c}\text { other weed } \\
\text { species }\end{array}$ & 3.5 & LDB \\
\hline 7 & $\begin{array}{c}\text { Tongue River } \\
\text { Reservoir (641.8) }\end{array}$ & $\begin{array}{c}\text { other weed } \\
\text { species }\end{array}$ & $1 / 8$ & LDA \\
\hline 4 & $\begin{array}{c}\text { Miles City } \\
\text { Fish Hatchery (245.6) }\end{array}$ & other weed species & 5 & LDB \\
\hline 4 & $\begin{array}{c}\text { Region Seven } \\
\text { Administrative Sites } \\
\text { (7.6) }\end{array}$ & none & & \\
\hline
\end{tabular}

1 Size - page 8

2 Density-page 8 


\section{Wildlife Management Areas}

DFWP manages WMA's with the needs of wildlife and the maintenance of habitat as primary objectives. Secondary objectives include providing recreational opportunities for the public. Each WMA is a unique portrait of landscape features, vegetation communities, and the environmental forces which shape them. For purposes of this report, R-7 WMA's have been broken down into three separate groups. Large, primarily mainland WMA's, Issac Homestead, Elk Island and Seven Sisters will each be considered separately. The two other groups consist of 1) small islands and wetlands areas in and/or adjacent to the Yellowstone River; and 2) large islands in the Yellowstone River.

\section{Fishing Access Sites}

DFWP manages FAS's to provide public access to high-quality fishing opportunities as well as to provide reasonable accommodations for vehicle parking, boat launching, and general recreation. As noted earlier, proximity to water and seed dispersal influence the degree and success of noxious weed establishment. Water courses disperse and transport seeds quite effectively. A small, localized weed population will be a seed source for downstream lands if seeds are introduced into a waterway. For that reason, FAS's for a particular drainage will constitute a property group.

In Region 7, several FAS's grant access to ponds or reservoirs and for purposes of this report, will be considered together.

\section{State Parks and Administrative Sites}

SP's attract visitors because of their natural, cultural, recreational, and historical resources. Picnicking and overnight camping opportunities also attract many visitors. Although there are similar opportunities and constraints for the treatment and management of noxious weeds in some SP's, each park was established for its unique features. Thus, groups, where possible, are based on broad cultural, historical, or natural resource similarities.

For purposes of this report, all Region 7 SP's will be considered separately. Differences in facility development and human use will be discussed in greater detail in Part 3.0. The Region 7 Headquarters complex will be included in the section with SP's as well as the one DFWP fish hatchery. 


\subsection{NOXIOUS WEED MANAGEMENT STRATEGIES}

\subsection{General Approach}

It is the goal of DFWP to be in compliance with state laws and county ordinances concerning noxious weeds where they are established. Furthermore, DFWP hopes to discourage the establishment of noxious weeds through the application of good land management principles and to reduce noxious weed populations over time with as few negative impacts to the State's resources as possible. To achieve these goals, DFWP crafted this Plan based on the concept of Integrated Noxious Weed Management (INWM). INWM is a multifaceted approach which tailors weed management activities to the treatment needs and site characteristics of a particular weed population. First, weed management priorities are established. Then, management methods and techniques are selected, including natural predators and parasites, environmental modifications, and chemical herbicides when necessary and appropriate. INWM allows for the most flexibility in managing noxious weeds as site conditions change, treatment methods improve, and funding opportunities arise. This approach is consistent with state law and the noxious weed plans developed by the counties. DFWP has been practicing some form of INWM informally since the early 1980's. This Plan formally adopts this approach.

\subsection{Conceptual Framework to Prioritize Activities}

Within the context of INWM, there are several ways to prioritize noxious weed management activities. These approaches include species-specific directives based in state law, treatment objectives based on location or size of weed populations, special management zones which require modification of general (area-wide) techniques, and property groups based on watershed or political boundaries. In using INWM, DFWP has adopted an approach which utilizes all of these concepts.

\subsubsection{Species Specific Directives}

As a state law, the County Noxious Weed Control Act mandates the management of certain species declared as "noxious." Thus, DFWP must attempt to treat and manage those species declared by the state as well as those species declared by the individual counties. On DFWP Region 7 sites, Canada thistle and Leafy spurge are the most prevalent noxious weeds, but other species are treated as well. Thus, efforts which have primarily been focused on these species will continue, but additional species may need to be added as the state and county noxious weed lists are amended. 


\subsubsection{Location and Population Size}

Noxious weed treatment priorities depend on the location and size of a weed population. Factors to consider are: the potential impact on site values in the absence of weed treatment, potential of weed spread, and the difficulty of satisfactory weed control. These same factors are considered by the state and counties during the process of listing weeds as "noxious." Priorities based on location and population size described below (Lolo National Forest 1989).

\section{Prevention}

Prevention describes the implementation of policies, programs, or activities that will minimize the possibility of introduction of noxious weeds or their seeds to DFWP sites from lands nearby. This approach will have a high priority for DFWP since the long term cost effectiveness is high. Attempts will be made to prevent the establishment of a new noxious weed species or new populations on Region 7 properties. Where newly discovered populations are small, the objective is immediate treatment to prevent any increase in size beyond manageable limits. Preventative measures under consideration include, but are not limited to, the following:

- Regulate or limit the use of vehicles that could spread and carry noxious weed seeds into an area.

- Require or promote the use of weed seed free materials for livestock feed, landscaping, revegetation, and construction activities, including topsoil, gravel, hay mulch, and seed mixes.

- Require the thorough cleaning of all heavy equipment used on Region 7 lands, where feasible.

- Cooperate in education programming initiated by other organizations, where feasible, concerning the problems caused by noxious weeds, how weeds spread, and how the spread can be curtailed.

\section{Eradication}

Eradication is an attempt to totally eliminate a noxious weed species or a particular weed patch from DFWP properties. Eradication is preferred where weed populations are small but have the potential to spread rapidly. However, this approach has limitations. Long term efforts may be required where the seed source is established; current technologies may not be adequate or practical; or total eradication efforts may result in unacceptable environmental consequences. When appropriate, eradication efforts would continue as long as detectable levels of the weed were present. For small populations, the cost effectiveness of eradication efforts is high. 


\section{Reduction or Suppression}

Reduction or suppression is an attempt to prevent seed production and distribution throughout the treatment area and reduce the coverage of the weed. Reduction will prevent the weed from dominating the vegetation of the area but will require the public and land managers to accept noxious weed presence at low levels since complete elimination would not be feasible. Reduction is preferred in most instances when light to moderate noxious weed populations exist in accessible areas.

\section{Containment}

Containment is an attempt to prevent (through eradication or die off) the spread of the weed beyond the perimeter of a weed patch or treatment area. Managers and the public must tolerate weeds within established areas, but not beyond current boundaries. Containment is the preferred approach when weed populations have grown so large or dense that reduction is not practical or possible. In some situations, weeds may exist in settings where all methods of treatment are either unacceptable or ineffective so that containment is the only practical course of action.

\section{Tolerance}

Tolerance is to accept the continued presence of established weed populations and the probable spread to ecological limits for a particular species. Tolerance should only be applied in the context of containment. Tolerance is only acceptable if noxious weeds are contained within an area and not allowed to spread beyond the ecosystem. Like containment, tolerance situations usually exist where noxious weeds are beyond control or are in environments where all methods of treatment are either unacceptable or ineffective. The manager must identify these situations and try to discourage weed encroachment through preventive practices.

\subsubsection{Special Management Zones}

Although weed treatment needs may be similar from site to site or within the boundaries of one particular site, each site is a unique juxtaposition of environmental features, visitor facility development, and level of human use. For these reasons, individual sites or groups of sites may be distinguished into management zones based on the following: presence of surface water or shallow groundwater, threatened, endangered, or sensitive species, intensity of human use, weed treatment objectives, or other factors. The framework of management zones permits the identification of weed treatment methods and techniques amenable to a particular weed patch should it require the modification of general area-wide weed treatments. Three zones have been identified: surface and groundwater, sensitive species, and high human use. Because of the sensitive nature of these special management zones, herbicide use will be somewhat limited. A discussion of each zone and guidelines for their protection follow. 


\section{Surface and Groundwater Zone}

Sensitive surface and groundwater zones constitute locations of aquatic vegetation, surface water, shallow groundwater, and groundwater recharge. Examples include wetlands or marshes, riparian areas, lakes or ponds, springs, rivers, flood plain, and pathways of overland runoff. Because of their high moisture content and abundant nutrients, these environments are highly productive, yielding valuable fishery and wildlife habitats, recreation areas, and livestock foraging areas. Such zones occur on a significant portion of DFWP properties in Region 7. Noxious weeds exist within many sensitive surface and groundwater areas. The weed management goal is to attempt to protect riparian areas and wetlands from encroachment by noxious weeds while preventing chemical contamination of surface and groundwater if weeds are treated in these zones.

Surface water zones can be determined by studying topographic features of a site. After surveying the presence and location of surface water, high water marks, and associated overland runoff contours, a chemical applicator can discover and avoid avenues of potential surface water contamination. In addition, a preliminary soil analysis will determine soil textures. Coarse, gravelly soils tend to have higher infiltration rates, which imply the potential to transport chemicals. The opposite is true of fine textured, clayey soils.

Sensitive groundwater zones could be identified on a soils map using a procedure developed for the Lewis \& Clark County Conservation District (Lacey 1991). Risk of chemical contamination of water resources is determined for a site based on depth to the seasonal or permanent water table, soil permeability, soil organic matter content, flooding hazard, and percent slope. A risk index based on these variables was calculated on a scale of 1 to 100 and divided into 4 categories or classes of risk. Risk factors and classes were then indicated on a map of soil units (Table 4). Until maps identifying sensitive groundwater zones become available and some of the other variables are quantified, the following guidelines are suggested to protect surface and groundwater from chemical contamination:

- Target noxious weeds encroaching upon sensitive surface and groundwater environments (e.g. Purple loosestrife) so weeds don't become well established.

- Avoid applying herbicides directly to standing or running water; maintain a 50 foot distance from surface waters when applying chemicals; when applying chemicals within 50 feet of a surface water, use a wick applicator; because manufacturer label restrictions are not always restrictive enough, more restrictive guidelines could be established as site conditions merit.

- Mix and load herbicides off-site as much as possible; mixing, if done on site, should be at least 500 feet from open water or shallow groundwater; water for tank mixing should be obtained off-site. 
- Avoid applying picloram on the immediate banks of a water body, below the high water line, or in high groundwater risk class areas.

- Encourage manual, cultural, and biological methods; if chemical methods are used, design and schedule herbicide treatments to have the least impact on fish, wildlife, non-target vegetation, and water quality.

- Avoid using boom sprayers where noxious weed plants and seeds are mixed with desirable woody vegetation; biological, cultural, or manual methods which target individual plants (e.g. wick applicator) are preferred in these settings.

- Avoid broadscale applications with high herbicide rates on areas where fractured bedrock lies close to the soil surface.

Table 4. Soil index values, risk classes, and soil descriptions used to identify groundwater areas sensitive to chemical contamination (Lacey 1991).

\begin{tabular}{lll}
\hline Index & Class & \multicolumn{1}{c}{ Soils Descriptions } \\
\hline $100+$ & $\begin{array}{r}\text { 1-Very } \\
\text { High }\end{array}$ & $\begin{array}{l}\text { Soils with water tables within 3 feet and moderately rapid to very } \\
\text { rapid permeability; herbicide use not recommended on these } \\
\text { sites. }\end{array}$
\end{tabular}

80-99 2-High Soils with water tables within 3-6 feet, moderate to rapid permeability, no flooding risk; or soils with water tables within 15 feet, moderately rapid to very rapid permeability, high flooding risk, and low organic matter; spot treatments with herbicides may be utilized in some areas; reduce herbicide rates and application frequency to decrease contamination risk; low leach potential and short residual herbicides recommended for any large scale applications.

60-79 3-Moderate Soils with water tables within 6-10 feet and moderately slow to very slow permeability; or soils with water tables within 15 feet and rapid to very rapid permeability; these soils often occur in association with high water table soils; herbicides can be used for spot treatments on these sites; large broadscale applications with high herbicide rates not recommended; decrease application frequency to reduce risk.

40-59 4-Slight Soils with water tables within 15-25 feet and moderate to moderately rapid permeability; soils occur where landscape features resemble those with high water table soils; may be located on benches and terraces adjacent to perennial or intermittent streams; few restrictions for herbicide use. 


\section{Sensitive Species Zone}

Sensitive species zones possess physical and biological features essential to the conservation or survival of plants or animals. Typically, these zones support animal or plant populations which may be adversely affected by the presence of noxious weeds or efforts to treat them. More specifically, they might provide vital habitat for species designated threatened or endangered under the Endangered Species Act or as sensitive by the Montana Natural Heritage Program. Noxious weeds occur in many sensitive species zones. The overall weed management goal within this zone is to protect existing, diverse habitats from encroachment by noxious weeds, while ensuring that threatened, endangered, rare or unique species are not adversely affected by their infestations and subsequent treatment activities. However, when sensitive species habitats are invaded by noxious weeds, special consideration should be given to treatment types and objectives. This consideration is critical when the sensitive species are plants themselves and where broadscale treatments, for example herbicide spraying or cultivation, could unknowingly kill all the sensitive plants in an infested area. In this instance, treatment objectives would first include containment of the infestation. Following that, information would be developed on how best to proceed. In Sensitive Species Zones, the following guidelines are offered:

- Determine sensitive species zones or identify and locate sensitive species populations for each property or group of properties and establish treatment buffers if necessary.

- Direct management towards weed populations in the vicinity of sensitive species zones before weeds become established in the sensitive zone.

- Encourage manual treatments, although some cultural and spot herbicide treatments may be considered where appropriate.

- Design and schedule herbicide treatments to have the least impact on wildlife, fisheries, and non-target vegetation.

- Avoid using boom sprayers in sensitive species zones where weeds are closely mixed with desirable woody vegetation.

- Consider revegetation or rehabilitation of treated wildlife habitat areas as part of the treatment plan to ensure that desirable ground cover is established without affecting sensitive plant species.

\section{High Human Use Zone}

High human use zones are areas which have concentrated and frequent recreationist or DFWP employee use. Examples include picnic table areas, tent sites, restrooms, drinking water well sites, interpretive sites, and boat launch areas. Because of the high degree of ground disturbance and the intense activity level, these areas are very susceptible to the 
encroachment and rapid spread of noxious weeds. Once invaded, these areas require aggressive treatment actions. The weed management goal is to reduce noxious weed populations in areas which are continually or heavily used by people, while simultaneously ensuring public health and safety. In the majority of situations, a buffer zone of at least 50 feet is maintained from such zones during chemical application. Weed management guidelines for this zone follow:

- Emphasize prevention as the key component of management efforts, primarily by cooperating with educational programming initiated by other organizations to increase public awareness of noxious weeds.

- Encourage manual, cultural, or biological treatments; consider the plausibility of spot herbicide treatments on a site by site basis.

- Post signs in high human use zones prior to and for 24 hours after herbicide applications to notify the public that spraying activities will/have occurred.

- Wash and rinse residue from surfaces used by the public for food handling if herbicides are applied within 50 feet.

- Use only those chemicals with label designations specifying permission for use in human occupation areas (e.g. glyphosate, clopyralid, and 2,4-D).

\subsection{Treatment Methods and Techniques}

Within the framework of INWM, there are four general weed treatment methods, each with several specific techniques or agents. Manual, cultural, biological, and chemical methods for the treatment and management of noxious weeds are described below, with specific techniques or agents identified. Additional methods and techniques will be considered in the future as they become available.

\subsubsection{Manual}

Manual techniques involve grubbing with hand tools (shovel, hoe, pulaski etc...), topping (shears, clippers, and "weed-whackers"), and hand-pulling to treat noxious weeds. These techniques can effectively reduce small populations of annual or biennial noxious weed species, primarily by reducing seed production. Periodic re-treatment is required. Because these techniques are labor intensive, their application would be mostly limited to environmentally or culturally sensitive areas. 


\subsubsection{Cultural}

Cultural techniques include burning, mowing, tilling, reseeding, and grazing. These techniques effectively reduce some noxious weed species, although implementation is often limited by topography and access. These techniques can also be costly and time consuming. Furthermore, some techniques disturb the soil which can contribute to noxious weed proliferation if revegetation does not occur rapidly.

\section{Burning}

As a treatment technique, burning alone is generally of limited effectiveness. It may be considered in the future in conjunction with other treatment techniques such as reseeding.

\section{Mowing and Tilling}

Mowing and tilling can prevent noxious weed plants from producing seeds when treated in the bud stage or earlier. Repeated efforts during a single growing season can deplete the underground food supply of some perennial species. These treatments would need to be repeated over at least a five-year period to attain satisfactory results since they do not eliminate weed plants themselves. These methods may also weaken non-target species. Mowing and tilling opportunities are often limited because of steep slopes and rugged terrain. Mowing would be considered on level or nearly level slopes, where suitable soils exist and where a small percentage of the vegetation consists of shrubs. Mowing is also an alternative in environmentally sensitive areas where other treatment methods are unsuitable. Tilling would be considered only for areas that had previously been or are currently under cultivation because ground disturbance may increase the likelihood of noxious weed establishment beyond the potential benefits of tilling. However, tilling combined with a reseeding program would be considered when economically feasible. Other treatment methods would also be considered in conjunction with tilling such as alternate cropping systems, grazing systems, or chemical applications.

\section{Reseeding}

Reseeding is required where plant communities are completely disturbed by facility construction. It may also be advisable where vegetation communities are dominated entirely by noxious weeds. Such revegetation projects require considerable effort to eliminate existing weeds, prepare a seedbed, re-seed and fertilize. In radically disturbed areas, it is imperative to plan and execute the re-vegetation project as soon as possible. Topsoil should be salvaged and replaced on the disturbed site immediately to encourage native species to sprout from seed, rhizomes, or other plant parts in the salvaged soil. Consideration should also be given to, topsoil protection, native seed selection and fertilization. Despite the significant expense, dramatic results can be achieved. 


\section{Grazing}

Grazing by domestic sheep and goats have effectively controlled the spread of Leafy spurge in certain situations in Montana as well as in North Dakota. Other weed species were often selected early in the growing season since they tend to green up earlier than native plants. Controlled livestock grazing incorporating adequate vegetative rest is utilized on several of the WMA's and one SP, to maintain and/or improve range condition thereby discouraging weed proliferation. Many Leafy spurge populations on Region 7 properties occur where careful herding and/or installation of temporary fences would be necessary. When considering this treatment technique, the effect of grazing on soils, water, and riparian areas will be considered.

\subsubsection{Biological}

Biological control methods are those which introduce natural enemies (insect pathogens) to a noxious weed population. Biological control agents stress noxious weeds, severely reducing seed production and/or plant viability. Biological agents will not eliminate the species, but can reduce the population to a tolerable level, particularly when used in combination with other treatment techniques. Biological control methods may be the only treatment possible in areas where manual, cultural, or chemical methods are not feasible.

Biocontrol agents are currently being developed and screened by universities and the USDA Animal, Plant and Health Inspection Service (APHIS). There are also commercial sources for a number of agents. Several biological agents have been released in the counties of Region 7. Release of biological control agents onto DFWP properties will be in cooperation with the counties, the Montana Agricultural and Experiment Station at Montana State University, and APHIS. DFWP personnel in Region 7 will work with APHIS to encourage the establishment of insectaries on certain properties which meet selected criteria. Over the long term, biological control agents are cost effective because expenses are limited to the collection and release of new agents and periodic monitoring to insure spread and infection. However, it remains to be seen whether biocontrol agents can keep pace with the rate of spread of certain noxious weed species, whether on DFWP properties or elsewhere.

With any biocontrol program, it is necessary to maintain a viable host population for the biological control organism. Areas selected for release of these agents will be screened with respect to location and plant community and an area determined to be necessary for the maintenance of a healthy biocontrol agent population will be precluded from weed eradiction objectives. Outside this area, weed infestations will be treated as necessary. Appendix D summarizes biological control agents currently available in Montana, and those which have been released on DFWP properties in Region 7. 


\subsubsection{Chemical}

Chemical methods involve the use of herbicides to kill weeds directly or the application of soil sterilants which prevent the germination of noxious weed seeds. Over the past halfcentury, chemical herbicides have been developed to treat a variety of weed species. While the benefits of chemical techniques include efficacy and low cost, there are valid concerns about any application of chemicals to the landscape. In addition to concerns about the effects of chemical exposure on human health and the environment, attention has also focused on chemical storage, handling, use, and disposal procedures. Herbicide manufacturers have responded to these issues with attempts to develop products that are: (a) more pest specific to reduce effects on non-target species; (b) less toxic to humans, birds, fish and other animals; and (c) less likely to impact the environment, particularly water quality. The following discussion highlights these points in greater detail.

\section{Efficacy and Cost}

Properly used chemical herbicides are usually effective against their targets. Variation in effectiveness is attributable to environmental conditions, skill of the applicator, condition of the equipment, application rates, and the target species. For example, Leafy spurge is difficult to eradicate with chemicals, whereas Spotted knapweed can be successfully eradicated in the short-term. Herbicides are relatively inexpensive to obtain and apply.

\section{Human Health Effects}

A definitive evaluation of human health risks from exposure to herbicides is beyond the scope of this Plan. The long-term health effects of chemical herbicides continue to be researched. Short-term health effects can be serious for sensitive individuals. Health effects are most commonly reported among herbicide applicators. Due to uncertainty over health and environmental effects, DFWP hopes to reduce the use of chemical herbicides over time.

\section{Environmental Concerns}

Environmental concerns over the storage, handling, use, and disposal of chemicals are based on four issues: persistence, potential for movement, contamination of surface and groundwater, and the potential for chemical spills.

Persistence refers to the longevity of a chemical's integrity. It is usually expressed as halflife or the length of time required for half of the substance to become inert. Herbicides are degraded by physical, chemical and biological processes. Many herbicides degrade to very low levels in soil after several weeks or months, whereas others persist for several months to years. Most herbicides are broken down and adsorbed in the uppermost 12 inches of the soil profile. 
Potential for movement describes the transport of chemicals through the environment as solids, liquids, and gases. Once applied, herbicides are absorbed, accumulated, degraded, diluted, inactivated, and/or mobilized. Solubility in water gives a preliminary indication of chemical mobility. The ultimate fate is heavily influenced by the type of herbicide, the application rate, environmental conditions at the time of application, and site characteristics. Individual properties or characteristics of herbicides also affect persistence and potential for movement due to the interaction of active ingredients with soil organic matter and clay particles. Research has been conducted on most common herbicides to establish environmental pathways and final fate. Research findings are incorporated into herbicide label instructions distributed with chemicals at purchase. These instructions are an important component of herbicide use and safety and will be discussed later.

Contamination of surface and groundwater results from improper use and application of chemical herbicides. Sandy and gravelly soils, having high infiltration and hydraulic conductivity rates, may transport chemicals directly to surface or groundwater. Transport may also occur where fractured bedrock lies close to the surface. Drainage paths, whether natural or artificially created, could also transport chemicals. These mechanisms of transport involve relatively low chemical concentrations, though some level of contamination may still result if appropriate applications guidelines are not followed.

In contrast, the potential for high chemical concentration levels exists in the event of a spill, with the extent of contamination depending of the nature of the spill. Many spills occur during transport, resulting from auto accidents. However, spills may also occur during application or storage. For these reasons, this Plan also outlines emergency response procedures in the event of an accidental spill. The Herbicide Emergency Response Plan is in Appendix E.

Because of the aforementioned concerns, DFWP intends to minimize the reliance on chemical methods as much as possible, while still meeting its legal responsibility to manage and treat noxious weeds on its properties. However, because the proliferation of noxious weeds does not appear to be decelerating, chemical methods remain a necessary component of this Plan. Therefore, it will be under the following guidelines that DFWP applies chemical herbicides to its properties:

- Consider the treatment objective, season of application, stage of plant growth, topography, species present, expected cost, equipment limitations, and potential environmental impacts during site specific planning.

- Determine rates of application from label instructions, taking into account target species, other vegetation in the area including desirable vegetation species, soil type, human occupation, wildlife, and the presence of surface waters or shallow groundwater. 
- Conduct and supervise all applications with an applicator licensed by the State of Montana, whether that individual is a Department employee or contractor.

- Use vehicle-mounted spray applicators (hand-gun, boom, injector etc...) in open areas that are readily accessible and where vehicle operation will not damage soil or vegetation; the boom will only be used for concentrated weed patches.

- Use hand applicators (backpacks or wipers) on small, scattered patches in rough terrain or environmentally sensitive areas.

- Monitor weather conditions during application periods to ensure effectiveness of the application and to reduce drift; spraying would cease when rainfall is expected within 24 hours, air temperatures exceed $85^{\circ} \mathrm{F}$, or wind speeds exceed 8 m.p.h.

- Dismiss the possibility of aerial herbicide applications for the present time. This is due to the relatively small size of DFWP sites (out of 39, 26 are 100 acres or less), or due to the constraints to chemical use on the majority of acreage within the sites. Chemical use constraints would include the presence of surface water (36 of 39), and the presence of desirable flora and fauna species and communities, including species of special concern.

- Design and adjust spray equipment to deliver a median drop diameter of 200-800 microns to reduce excessive drift.

- Conduct calibration checks at the beginning of the spraying season and periodically to ensure that equipment is functioning properly and that the desired applications rates are achieved, when feasible.

- Attempt to apply herbicides during the optimum stage of plant growth to achieve maximum effect using the least amount of herbicide; this is usually in the spring and/or fall when adequate soil moisture is available for plant growth and herbicide uptake.

- Mix a dye, when feasible, with the herbicide solution to aid in identifying where spraying has occurred in order to prevent "double-spraying" and to provide a means of checking coverage for monitoring purposes.

- Avoid applying picloram to dense stands of noxious weeds in sequential years to prevent overuse of a persistent chemical capable of leaching into groundwater.

- Follow all herbicide label instructions, observing restrictions; additional precautions may also be taken. 


\subsection{Inventory and Monitoring Procedures}

Prior to the preparation of this Plan, a comprehensive field inventory of weed infestations was conducted during the summer of 1993. Prior to- and following 1993, inventories have consisted of field reconnaissance by DFWP personnel or DFWP contractors. In all three instances, efforts have noted the weed species present, location, approximate acreage and density of the infestation. See Tables 1, 2, and 3 for a summary. Based on this information, weed treatment activities are prioritized using the conceptual framework presented previously. Subsequently, work plans for the following field season are outlined. Monitoring on a yearly basis will be conducted through similar informal field reconnaissance methods. Priorities and treatment methods can be adjusted as necessary, due to the dynamic nature of noxious weed seed germination and plant growth.

\subsection{Assignment of Plan Responsibilities}

\subsubsection{Oversight of Plan Implementation}

As the result of ongoing DFWP efforts to decentralize decision making and return this responsibility to the field regions, the ultimate responsibility for implementation of this Plan rests with the R-7 Regional Supervisor. ' However, the most direct oversight of field personnel or contractors conducting weed treatments is the responsibility of the Regional Park Maintenance Supervisor, the area Wildlife Biologist(s) and the Fish Hatchery Manager for the lands under their jurisdiction, respectively. For example, the Regional Park Maintenance Supervisor would directly oversee activities on all SP's, Administrative Sites and FAS properties; whereas, the area Wildlife Biologist(s) would oversee weed treatments on WMA's. Figure 2, on pages $28-30$, outlines where weed management responsibilities lie within Region 7.

\subsubsection{DFWP R-7 Applicators, Licenses and Record Keeping}

Applicators of restricted use herbicides must be licensed by the State of Montana. To obtain a license, the applicator must take training courses and pass an exam. To retain that license, the applicator must earn re-certification credits in government-approved courses. Because Parks Division personnel apply herbicides to SP and FAS properties, the Regional Park Maintenance Supervisor is required to obtain and hold a pesticide applicators license. Through re-certification and other training opportunities, continuing access to current weed control information including integrated weed management practices are encouraged. On WMA's, pesticide applications are made by private agricultural lessees and contractors who are required by law to secure there own applicators licenses. Area Wildlife Managers draw on their extensive knowledge of botany and soil science to guide weed management activities on WMA's. State law also requires that applicators record their use of restricted herbicides. 
Records must indicate the location's legal description, the chemical applied, rate of mixing, the applicators, the weather conditions at the time of application, and the number of acres treated. These records must be submitted to the State Department of Agriculture one out of every five years. In addition, the records must be made available to state investigative officers at any time following an herbicide application. All aspects of applicator licensing, re-certification training and record keeping regulations administered by the State are supervised by the United States Environmental Protection Agency. Appendix G outlines herbicides used in Region 7.

In addition to all State and Federal reporting requirements, DFWP policy also requires the annual reporting of all measurable weed treatment activities conducted on any Department property, regardless of the methods and techniques employed. All cultural, manual, biological, and chemical treatments are recorded according to county and site name, type of action, species treated, numbers of acres treated, application rate, frequency of treatment and total cost. Periodically, the Department produces summary reports of all noxious weed management activities statewide. Region 7 reports are filed at the Regional Headquarters Office, please consult Figure 2, on pages 28-30, where specific reports are located.

\subsubsection{Contracted Services}

Some weed management activities in Region 7, especially herbicide applications, have and will continue to be contracted to private individuals and the county weed control departments. All contractors must be licensed by the State and knowledgeable concerning the specific weeds to be treated and chemicals to be used. Contractors must also sign and comply with a State Personal Services Contract or other appropriate agreement - for example, a WMA agricultural lease. Contractors should be familiar with all components of this Plan, especially those regarding safety and emergency response. Contractors must be provided with clear information and directions and be supervised to insure compliance with contract specifications and this plan.

Contractors with the DFWP will be required to keep detailed records concerning applications. This will be coordinated with other herbicide use and reporting programs required by, and of, the DFWP. Contractors utilizing non-chemical methods of weed treatment would also be provided with the necessary information and direction to meet the specifications of the contract and this Plan. Their activities will also be recorded and filed. Please consult Figure 2, on pages 28-30, to find where specific reports are located. 


\title{
REGIONAL SUPERVISOR
}

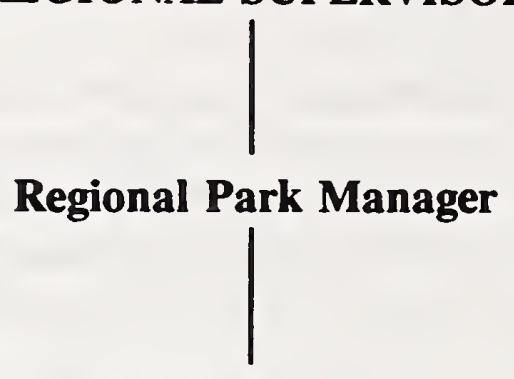

Regional Park Maintenance Supervisor

\author{
All State Parks (6), \\ All Fishing Access Sites (21) \\ R-7 Administrative Sites (2)
}

Secure Pesticide Applicators License - Restricted-Use Pesticides, Regulatory Weed Retain Pesticide Applicators License through required accumulation of CEC's

Site survey and inventory for weed infestations

Preparation of biennial weed control workplans

Preparation of biennial weed control budget requests

Supervise DFWP application, other methods \& treatments

Purchase, rent and maintain control equipment

Preparation of weed control contracts

Supervision of weed control contracts

Solicit, enter and collaborate in supervision of Weed Management Cooperative

Agreements

Prepare DFWP applicator/application records

Request applicator/application records from DFWP contractors, Cooperative partners

File and maintain all records per State and Federal rules

Procurement and handling of chemicals

Procurement and handling of bio-control agents

Monitor weed treatment sites for results

Bi-annual meetings with County Weed Supervisors

Preparation of biennial weed control activity reports

Annual weed control activity reports - DFWP

5 year MT Dept. of Agriculture pesticide use reports

Training of DFWP applicators (operators)

Attend/participate in County Extension Field Days

Attend/participate in annual SE Montana Weed Control Association Meetings

Review, assess and implement new weed control methods and techniques

Review, assess and implement new safety considerations

Update management plans

Figure 2. Assignment of Plan Responsibilities in Region 7 
REGIONAL SUPERVISOR

Miles City Fish Hatchery Manager

Fish Hatchery Complex

Secure Pesticide Applicators License - Restricted-Use Pesticides, Regulatory Weed

File and maintain all records per State and Federal rules

Retain Pesticide Applicators License through required accumulation of CEC's

Procurement and handling of chemicals

Site survey and inventory for weed infestations

Procurement and handling of bio-control agents

Preparation of biennial weed control workplans

Monitor weed treatment sites for results

Preparation of biennial weed control budget requests

Bi-annual meetings with County Weed Supervisors

Supervise DFWP application, other methods and treatments

Preparation of biennial weed control activity reports

Purchase or rent and maintain control equipment

Annual weed control activity reports - DFWP

Preparation of weed control contracts

5 year MT Dept. of Agriculture pesticide use reports

Supervision of weed control contracts

Training of DFWP applicators (operators)

Solicit, enter and collaborate in supervision of Weed Management Cooperative Agreements

Review, assess and implement new weed control methods and techniques

Prepare DFWP applicator/application records

Review, assess and implement new safety considerations

Request applicator/application records from DFWP contractors, Cooperative partners

Update management plans

Figure 2 (cont). Assignment of Plan Responsibilities in Region 7 


\section{REGIONAL SUPERVISOR}

Regional Wildlife Manager

Area Wildlife Biologist's ( 3 areas)

\#1. Isaac Homestead, Sanders, Howard Valley WMA's

\#2. Elk Island, Seven Sisters, F Island, War Dance, Three Mile Island WMA's

\#3. Fort Keogh Islands, Badlands WMA's

Site Survey and inventory for weed infestations

Preparation of biennial weed control workplans

Preparation of biennial weed control budget requests

Preparation of weed control contracts

Supervision of weed control contracts

Solicit, enter and collaborate in supervision of Weed Management Cooperative Agreements

Request applicator/application records from DFWP contractors, cooperative partners

File and maintain all records per State and Federal rules

Bi-annual meetings with County Weed Supervisors

Preparation of biennial weed control activity reports

Annual weed control activity reports - DFWP

5 year Mt. Department of Agriculture pesticide use reports

Update management plans

Figure 2 (cont). Assignment of Plan Responsibilities in Region 7 


\subsection{Other Subjects of Concern}

\subsubsection{Threatened, Endangered and Sensitive Species}

One goal of this Plan is the preservation of fisheries, wildlife, and vegetation resources under the stewardship of DFWP in Region 7. Land management agencies and conservation organizations have developed lists of threatened, endangered, or sensitive plant and animal species. Those species listed in Montana are of concern due to relatively small population sizes and/or limited distributions. Appendix F summarizes reported occurrences of such species on or near DFWP sites in Region 7 (Montana Natural Heritage Program 1995). Properties in this Region include aquatic, dry forest types and shrub grasslands; some with similar environmental and site conditions as habitats supporting listed species. DFWP personnel involved in weed management activities will consult the region's list (Appendix F) on a periodic basis.

DFWP personnel involved in weed management activities should be aware of this list. In addition, this list will be updated with input from the DFWP Plant Ecologist and the Endangered Species Program Coordinator.

\subsubsection{Herbicide Labels}

Herbicide labels are an important component of chemical use and safety, and are supplied with each container of product. The detailed information provided by the label meets four important goals of herbicide regulation, including: chemical identification, protection of human health and the environment, special practices and legal requirements. Herbicide labels have the force of law and should be an integral part of any chemical weed management program. Appendix $\mathrm{H}$ contains manufacturer labels for those herbicides proposed for use in Region 7. 


\subsection{PROPERTY GROUP TREATMENT PLANS}

In most cases, existing information is sufficient to define the conditions of DFWP Region 7 properties with respect to noxious weeds. Property group treatment plans were prepared based on this data. Plan preparation was also guided by the following factors, each of which stems from the conceptual framework to prioritize weed management activities discussed in Part 2.0 of this Plan:

- weed species present

- size and density of weed populations

- management objectives

- potential for successful treatment

- potential for spread on DFWP property

- potential for spread beyond DFWP property

- public concern over weeds or weed management efforts

- existing local weed management projects

- budget and personnel constraints

\subsection{Wildlife Management Areas}

\subsubsection{Introduction}

Wildlife Management Areas (WMA's) and Wildlife Habitat Protection Areas" (WHPA's) are managed to meet the needs of wildlife, preserve wildlife habitat, and provide recreational opportunities to hunt, fish, or view wildlife in their natural habitats. Site specific, integrated resource management plans are in various stages of development and/or revision and will be filed at the Regional Headquarters Office as they are finalized. These management plans describe overall management direction and specify certain activities to be undertaken to reach some desired future condition. Common to every WMA management plan is the application of proper land management practices to maintain or enhance healthy, vigorous vegetation communities. To the degree that vegetation communities are healthy and vigorous, they will be able to resist noxious weed encroachment. Furthermore, the quality of wildlife habitat is directly linked to the health and stability of vegetation communities. Thus, the prevention of noxious weed encroachment is inherent in the administration of these properties.

In Region 7 for all intent and purposes, WMA's and WHPA's are treated the same for the purpose of noxious weed management. For purposes of this report; hereafter, both will be referred to as WMA's. 
On WMA's, good land management begins with protecting the soil and vegetation resources. All WMA's have vehicle restrictions intended to prevent excessive soil disturbance and/or erosion. Motorized vehicles are restricted to established roads or trails and designated parking areas. Vegetation and soil resources are also protected by requiring the use of certified weed seed free hay to prevent the introduction of noxious weed seeds to WMA's.

WMA's are a small part of a larger landscape in which, unfortunately, noxious weeds occur, and noxious weeds have been documented on the WMA's in Region 7. DFWP is required by law to attempt to manage noxious weeds on its properties. As such, any noxious weed management should be approached on the landscape level, considering neighboring landowners, land use practices, and mechanisms of noxious weed seed dispersal. To that end, noxious weed management on the WMA's will center around maintaining healthy vegetation communities, deterring seed dispersal, and the detection and treatment of noxious weed outbreaks before they become well established.

Quick detection and treatment of small patches is the most efficient approach to managing noxious weed outbreaks. As populations increase, the number of potential treatment methods dwindles as other considerations come into play. For example, chemicals could be applied to a 1/10 acre patch with some risk to other vegetation, but they could not be applied broadscale to a 10 acre patch without potential impacts on non-target vegetation or other resource values. In addition, seed production influences the long term success of weed treatments. The volume of seeds produced on a $1 / 10$ acre patch is much less than that of a 10 acre patch; thus, making it easier to confine or eradicate the smaller one.

Budget and personnel constraints necessitate the implementation (when necessary) of treatment methods which maximize the ratio of expedient, successful noxious weed treatment to cost. Of the methods currently available, chemical treatments offer the most cost effective means of weed management. However, there are circumstances where chemical methods are not feasible, such as near surface waters or where weeds cover a wide area. Manual methods are not practical in most cases because of budget and personnel limitations. Cultural methods, though effective in certain situations, sometimes result in additional soil and vegetation disturbances, two factors contributing to the spread of noxious weeds. Biocontrol methods offer a cost effective alternative though they are not appropriate in all settings. Furthermore, biocontrol agents are not yet readily available. Only a few sources dispense agents commercially, at a premium price; otherwise, agents must be obtained from APHIS.

Of the ten WMA's in Region 7, five are small islands or marsh lands in/or adjacent to the Yellowstone River. These properties are similar enough in their physical aspects that they can be discussed together. Two WMA's are larger Yellowstone River islands which also are similar enough to be discussed together. Each of the three remaining WMA's will be discussed individually with respect to the status of noxious weeds and management strategies. It should be noted here that all three areas: Elk Island, Issac Homestead and Seven Sisters WMA's currently have formal noxious weed management plans in effect (the 
plans are on file in the R-7 Regional Wildlife Manager's office), and upon adoption, this plan will supersede these older documents. Recall that Table 1 summarizes the noxious weed species present and status for WMA's in Region 7. It should be pointed out that the estimated area (in acres) presented in Table 1 is cumulative for an entire site, since weeds are not continuously distributed throughout a WMA. That is, estimated acres of weeds along roadways are added to estimated acres in remote locations to obtain a total amount of acres. Figure 3 illustrates the location of the WMA's in Region 7.

\subsubsection{Former Glacier Park Co. Parcels}

\section{Existing Environment}

As the title to this section implies, this group of six land parcels were previously owned by the Glacier Park Co. and were donated to the State of Montana, DFWP in 1990. All of the parcels are located in or adjacent to the Yellowstone River, two are small islands and the remainder riparian or marsh areas. Five of the six parcels are less than 12 acres in size, the remaining one 32 acres in size. In accepting this gift, the DFWP agreed to manage the sites as WMA's, thus, providing for a limited amount of habitat and hunting opportunities. The sites are completely undeveloped and are not signed as public land. Public use is estimated to be very limited and consists primarily of hunting and the occasional visit by anglers.

Of the six WMA's in this group, land types consist of varying amounts of riverwash areas and undifferentiated river bottom land consisting of riparian vegetation dominated by either a Cottonwood tree overstory, various tall shrubs (primarily willow), short shrubs (rose, snowberry) and a few may feature small grassy areas. One of the areas, War Dance WMA, is an 11 acre marsh adjacent to the Yellowstone River, consisting primarily of cattails, rushes and sedges.

\section{Weed Status}

At the present time, no known infestations exist on these parcels. Since these parcels are in or adjacent to the Yellowstone River there is an increased potential for noxious weed introduction from adjacent and upstream lands in the river corridor.

\section{Site Constraints}

Chemical treatment of noxious weeds on this property group is constrained by the presence of surface waters (Yellowstone River) and by moderately permeable soil textures which could transport chemicals to shallow, seasonal groundwater tables. Riparian vegetation consisting of cottonwood/willow bottoms with a shrub and herbaceous understory component and wetlands areas may also preclude certain chemical treatments. 


\section{Weed Management Strategies and Methods}

The parcels contained in this property group have been checked for weed infestations on a frequent basis in the past. As of this date, no noxious weed infestations have been noted. This is due in no small part to the relatively "pristine" nature of the parcels and resulting resistance to weed infestations. Another possible factor in this is the relatively light public use these parcels receive.

Weed management goals for these properties will be to prevent infestations from occurring and the control methods will continue much as they have, with annual inspections for noxious weeds. If weeds are found, control methods will consist primarily of a combination of biological and manual techniques. Any weed management actions will be conducted subject to the guidelines presented in this Plan.

\subsubsection{F Island and Fort Keogh Islands}

\section{Existing Environment}

F Island WHPA is a Department of Natural Resources (DNRC) lease, located in the Yellowstone River approximately 3 miles upriver from State Highway Bridge 23 in Richland County. The island is approximately 95 acres in size and lies adjacent to the west bank of the Yellowstone in this section of the river.

Fort Keogh Islands WHPA is a DNRC lease, located in the Yellowstone River approximately $11 / 2$ miles upriver from Miles City. The set of two islands is approximately 79 acres in size and are located immediately down river from the abandoned Milwaukee St. Paul and Pacific Railway bridge.

Both islands provide public hunting opportunities via boat access and primarily serve hunters in and around the Sidney area for F Island and the Miles City area for the Fort Keogh Islands. Both are completely undeveloped and are not signed as public land. Public use of these WHPA's is probably limited and consists primarily of hunting and the occasional visit by anglers.

Land types for both islands consist primarily of river wash areas and undifferentiated river bottom land containing riparian vegetation dominated by a Cottonwood tree overstory, tall shrubs (willow), Russian olive, and various short shrubs (snowberry and wild rose).

\section{Weed Status}

At the present time, no known infestations exist on either F Island or Fort Keogh Islands WHPA's. Since both areas are Yellowstone River islands, there is an increased potential for noxious weed introduction from adjacent and upstream lands in the river corridor. 


\section{$\underline{\text { Site Constraints }}$}

Chemical treatment of noxious weeds on these WHPA's is constrained by the presence of surface waters (Yellowstone River) and by moderately permeable soil textures which could transport chemicals to shallow, seasonal groundwater tables. Riparian vegetation consisting of cottonwood/willow bottoms with a shrub and herbaceous understory component may also preclude certain chemical treatments.

\section{Weed Management Strategies and Methods}

Both F Island and Fort Keogh Islands WHPA's have been checked for weed infestations on a frequent basis in the past and at the current time, no noxious weed infestations have been noted. This is due in no small part to the relatively "pristine" nature of the islands and their resulting resistance to weed infestations. Another possible factor in this is the relatively light public use both areas receive.

Weed management goals for F Island and Fort Keogh Islands WHPA's will be to prevent infestations from occurring and control methods will continue much as they have, with annual inspections for noxious weeds. If weeds are found, control methods will consist primarily of a combination of biological and manual techniques. Any weed management actions will be conducted subject to the guidelines presented in this Plan.

\subsubsection{Elk Island}

\section{Existing Environment}

The initial land acquisition for Elk Island WMA occurred in 1975. Since that time, additional land has been acquired through lease so that presently DFWP administers 656 acres of deeded land and 552.5 acres of land leased from DNRC, BLM and the BN/Santa Fe Railroad. Elk Island WMA, located in Richland County near the community of Savage, is surrounded for the most part by private land, although it shares a small boundary with BLM lands on the south side of the Yellowstone River and BN/Santa Fe Railroad on the west/southwest border of the property. The site provides opportunities for wildlife habitat enhancement and protection and recreational use including hunting, fishing, hiking, and berry picking among others. In addition, 656 acres of Elk Island WMA is leased to a private farm/ranch cooperator who currently both farms and grazes livestock on the lease. Access to the area is provided by a county road leading southeast from Savage and by a small road system within the WMA developed by the DFWP. Recreational developments, in addition to the access roads, include a boat ramp and parking area on the Yellowstone River.

Elk Island WMA consists of mainland and island properties in and adjacent to the Yellowstone River. Land types for the area consist primarily of river wash areas, undifferentiated river bottom land containing riparian vegetation dominated by a 
Cottonwood tree overstory, tall shrubs (willow), Russian olive, and various short shrubs (snowberry and wild rose) and marsh areas consisting of cattails, rushes and sedges. Croplands in the area consist of hay and grain fields.

The management goals of Elk Island WMA are to benefit current and future generations of Montanan's by providing high quality outdoor recreational opportunities. At Elk Island, the focus is primarily on deer and upland game bird hunting opportunities. By providing public access to the property, and by utilizing and manipulating current farming and grazing practices to produce crops, livestock and wildlife, land management practices at Elk Island seek to provide an example of sustainable multiple use of agricultural land.

One aspect of the land management responsibilities at Elk Island WMA is noxious weed control. Control of noxious weeds on all agricultural leased land within a WMA is the responsibility of the lessees and is agreed upon in the lease document. The area wildlife biologist oversees the lessee's weed control activities, providing assistance in weed control management goals, survey and inventories, selection of treatments, and in some instances help in the actual control work. For those WMA lands outside the agriculture lease, responsibility for control rests with the DFWP. In the past, weed control efforts on the non-lease lands have been carried out by the agriculture lease holder under contract with the DFWP.

\section{Weed Status}

In total, approximately 30 acres of knapweed, Canada thistle, and Leafy spurge occur on Elk Island WMA (Table 1). Knapweed accounts for approximately 25 acres of the total, occurring at low densities in a 29 acre crop field and 4 small patches ( $X<1,000$ sq.ft.) on native range sites. Leafy spurge is limited to small woodland site totalling less than 2,500 sq.ft. Canada thistle is a weed infesting approximately 3 acres, primarily found in cropland sites. At the present time, weeds on the WMA are contained or being reduced from their current levels through a combination of annual chemical treatments, mowing and tillage operations on cropland sites. Possible sources for weed infestations into Elk Island include adjacent and upriver private lands, a large irrigation canal and railroad corridor both which traverse a small corner of the property and visitor use of the site.

\section{Site Constraints}

Chemical treatments of weeds on Elk Island WMA are constrained by the presence of surface waters from the Yellowstone River which is braided into a number of river channels and sloughs which contain wetland areas and riparian vegetation consisting of cottonwood/willow bottoms with a shrub and herbaceous understory component. Also present is a large irrigation canal, although confined to an existing corridor. 


\section{Weed Management Strategies and Methods}

Currently, patches of knapweed in the cropland area are controlled by a combination of mechanical and biological grazing which stimulates competing vegetation and by chemical applications. Knapweed in the native range sites is being controlled by chemical, mowing and hand pulling methods. Canada thistle is being controlled through normal field tillage operations followed by appropriate chemical methods to cropland.

The DFWP will also attempt to curtail the spread of established weed species by restricting vehicles to established roads. However, due to the mobility of our society and to the fact that the public is welcome to (and does) use public resources like Elk Island WMA, noxious weeds will likely persist. Therefore, the weed management goals are to attempt to reduce, or eradicate if possible; or contain weeds at their current levels and locations to prevent weeds from spreading to or from adjacent lands and to comply with county ordinances and state law concerning noxious weeds. The primary treatment method will be chemical, subject to the guidelines outlined previously in Part 2.0 of this Plan. Where use of chemicals is inappropriate, manual, cultural, or biological methods will be used. Where possible, weed management efforts will be coordinated with adjacent landowners including private, BLM and the railroad $\mathrm{BN} / \mathrm{Santa} \mathrm{Fe}$ in recognition of the landscape aspect of noxious weeds and seed dispersal.

\subsubsection{Isaac Homestead}

\section{Existing Environment}

The initial land acquisition for Isaac Homestead WMA occurred in 1969. Since that time, additional land has been acquired so that presently DFWP administers 1,168.5 acres of deeded land. Isaac Homestead WMA is located in Treasure County near the community of Meyer's. It is surrounded for the most part by private agricultural land, although it shares a common boundary (Yellowstone River) with BLM lands on the southeast side of the property. All lands within the WMA are mainland properties adjacent to the Yellowstone River. The site provides opportunities for wildlife habitat enhancement and protection and recreational use including hunting, fishing, hiking, and berry picking among others. In addition, 660 acres of Isaac Homestead WMA is leased to a private farm/ranch cooperator who currently both farms and grazes livestock on the lease. Access to the area is provided by a county road leading northeast from the Meyer's area and by a very limited road system within the WMA. There are no recreational developments on the property.

The management goals of Isaac Homestead WMA are to benefit current and future generations of Montanan's by providing high quality outdoor recreational opportunities. At Isaac Homestead, the focus is primarily on deer and upland game bird hunting opportunities. By providing public access to the property, by utilizing and manipulating current farming and grazing practices to produce crops, livestock and wildlife, land management practices at Isaac Homestead seek to provide an example of sustainable multiple use of agricultural land. 
Land types for the area consist primarily of river wash areas, undifferentiated river bottom land containing riparian vegetation dominated by a Cottonwood tree overstory, tall shrubs willow, Russian olive, and various short shrubs snowberry and wild rose and marsh areas consisting of cattails, rushes and sedges. Croplands in the area consist of hay and grain fields.

One aspect of the land management responsibilities at Isaac Homestead WMA is noxious weed control. Control of noxious weeds on all agricultural leased land within a WMA is the responsibility of the lessees and is agreed upon in the lease document. The area wildlife biologist oversees the lessee's weed control activities, providing assistance in weed control management goals, survey/inventories and selection of treatments. For those WMA lands outside the agricultural leases, responsibility for control rests with the DFWP. In the past, weed control efforts on the non-lease lands has been carried out by the agricultural lease holder under contract with the DFWP.

\section{Weed Status}

In total, approximately 7 acres of knapweed and Canada thistle occur on Isaac Homestead WMA (Table 1). In addition, there are approximately 14 acres of other weed species found at Isaac Homestead including Common burdock, Poison hemlock and Field bindweed. Knapweed accounts for approximately 2 acres of the total, occurring at low densities in two isolated rangeland patches of about 1 acre each. Canada thistle and Field bindweed are weeds infesting approximately 5 acres, primarily found in cropland sites. Common burdock and Poison hemlock are infesting two small rangeland sites $(X<500$ sq.ft.). At the present time, weeds on the WMA are contained or being reduced from their current levels through a combination of annual chemical treatments, hand pulling and mowing and tillage operations on cropland sites. Possible sources for weed infestations into Isaac Homestead include adjacent private lands and the river corridor.

\section{Site Constraints}

Chemical treatment of noxious weeds on this property group is constrained by the presence of surface waters (Yellowstone. River) and by moderately permeable soil textures which could transport chemicals to shallow, seasonal groundwater tables. Riparian vegetation consisting of cottonwood/willow bottoms with a shrub and herbaceous understory component and wetlands areas may also preclude certain chemical treatments.

\section{Weed Management Strategies and Methods}

Currently the patches of knapweed in the isolated rangeland sites are being controlled by a combination of hand pulling and chemical applications. Control of Canada thistle and Field bindweed located in agricultural fields is by a combination of normal field tillage operations and chemical applications. Control of Common burdock and Poison hemlock has been by a combination of hand pulling and chemical applications. 
The DFWP will also attempt to curtail spread of established weed species by restricting vehicles to established roads. However, due to the mobility of our society and to the fact that the public is welcome to (and does) use public resources like Isaac Homestead WMA, noxious weeds will likely persist. Therefore, the weed management goals are an attempt to reduce or eradicate if possible or contain weeds at their current levels and locations to prevent weeds from spreading to or from adjacent lands, and to comply with county ordinances and state law concerning noxious weeds. The primary treatment method will be chemical, subject to the guidelines outlined previously in Part 2.0 of this Plan. Where use of chemicals is inappropriate, manual, cultural, or biological methods will be used. Where possible, weed management efforts will be coordinated with adjacent landowners in recognition of the landscape aspect of noxious weeds and seed dispersal.

\subsubsection{Seven Sisters}

\section{Existing Environment}

The initial land acquisition for Seven Sisters WMA occurred in 1974. Since that time, additional land has been purchased and leased so that presently DFWP administers 597 acres of deeded land and 38 acres of land lease from the DNRC. The site is located in Richland County east of the community of Crane and is surrounded for the most part by private agricultural land, although it shares a corner boundary with BLM lands off the NE boundary and is adjacent to the BN/Santa Fe rail corridor along the western boundary. Seven Sisters provides opportunities for wildlife habitat enhancement and protection and recreational use including hunting, fishing, hiking, and berry picking among others. In addition, 38 acres of the site is leased to a private farm/ranch cooperator who currently both farms and grazes livestock on the lease. Access to Seven Sisters is provided by a county road leading east from Crane and by a limited road system within the WMA, developed by the DFWP. Recreational developments, in addition to access roads, include a boat ramp and parking area on the Yellowstone River.

Seven Sisters WMA consists of lands adjacent to the Yellowstone River. Land types for the area consist primarily of river wash areas, undifferentiated river bottom land containing riparian vegetation dominated by a Cottonwood tree overstory, tall shrubs - willow, Russian olive, and various short shrubs snowberry and wild rose, and marsh areas consisting of cattails, rushes and sedges. Croplands in the area consist of hay and grain fields.

The management goals of Seven Sister's WMA are to benefit current and future generations of Montanan's by providing high quality outdoor recreational opportunities. At Seven Sister's, the focus is primarily on deer and upland game bird hunting opportunities. By providing public access to the property, by utilizing and manipulating current farming and grazing practices to produce crops, livestock and wildlife, land management practices at Seven Sister's seek to provide an example of sustainable multiple use of agricultural land. 
One aspect of the land management responsibilities at Seven Sister's WMA is noxious weed control. Control of noxious weeds on all agricultural leased land within a WMA is the responsibility of the lessees and is agreed upon in the lease document. The area wildlife biologist oversees the lessee's weed control activities, providing assistance in weed control management goals, survey/inventories and selection of treatments. For those WMA lands outside the agricultural leases, responsibility for control rests with the DFWP. In the past, weed control efforts on the non-lease lands, has been carried out by the agricultural lease holder under contract with the DFWP.

\section{Weed Status}

Approximately 2 acres of Leafy spurge and Canada thistle occur on Seven Sisters WMA (Table 1). Leafy spurge is found at low densities in a few isolated rangeland patches totalling less than 2,000 square feet. Canada thistle and Field bindweed are weeds infesting approximately 2 acres of primarily cropland sites. At the present time, weeds on the WMA are contained or being reduced from their current levels through a combination of annual chemical treatments, hand pulling and mowing and tillage operations on cropland sites. Possible sources for weed infestations into Seven Sisters WMA include adjacent private lands, the river corridor, a railroad corridor which borders the western boundary and visitor use of the site.

\section{Site Constraints}

Chemical treatment of noxious weeds on this property group is constrained by the presence of surface waters (Yellowstone River) and by moderately permeable soil textures which could transport chemicals to shallow, seasonal groundwater tables. Riparian vegetation consisting of cottonwood/willow bottoms with a shrub and herbaceous understory component and wetlands areas may also preclude certain chemical treatments.

\section{Weed Management Strategies and Methods}

Currently the patches of Leafy spurge in isolated rangeland sites are being controlled by a combination of hand pulling, mowing followed by spot chemical applications. Control of Canada thistle and Field bindweed located in agricultural fields is by a combination of normal field tillage operations and chemical applications.

The DFWP will also attempt to curtail spread of established weed species by restricting vehicles to established roads. However, due to the mobility of our society and to the fact that the public is welcome to (and does) use public resources like Seven Sisters WMA, noxious weeds will likely persist. Therefore, the weed management goals are an attempt to reduce or eradicate if possible or contain weeds at their current levels and locations to prevent weeds from spreading to or from adjacent lands, and to comply with county ordinances and state law concerning noxious weeds. The primary treatment method will be chemical, subject to the guidelines outlined previously in Part 2.0 of this Plan. Where use 
of chemicals is inappropriate, manual, cultural, or biological methods will be used. Where possible, weed management efforts will be coordinated with adjacent landowners in recognition of the landscape aspect of noxious weeds and seed dispersal.

\section{Fishing Access Sites}

\subsubsection{Introduction}

Fishing and related pursuits are significant components of eastern Montana's recreational industry. Angling pressure in DFWP's Region 7 (total days of fishing per year) approached 200,000 angler days during the 1995 season (Phil Stewart, DFWP). Region 7 contains approximately 909 miles of major fishing rivers and creeks, along with public fishing reservoirs and ponds. Public enjoyment of such resources would not be possible without access.

FAS's are properties owned by or leased to DFWP along surface watercourses or lakes. Through this ownership, FAS's provide access to river areas for the general public to engage in primarily angling pursuits. Watercourses with their associated vegetation communities (riparian zones) are some of the most diverse, productive habitats available to wildlife. For example, riparian woodlands in the west support the greatest diversity and abundance of neotropical migrant songbirds both during the breeding season and during migration (Dobkin 1992). These species are particularly dependent on the complexity and density of vegetation structure, especially in the shrub and herbaceous layers. Furthermore, riparian zones add tremendous diversity to the surrounding landscape.

In addition to their significant value to wildlife, FAS's are also valued by outdoor recreationists. Public use occurs during all seasons, although it is more concentrated during the angling season. The setting and visitor use facilities at a typical FAS's include the following: surface water body (stream or lake), access roads, parking areas, outhouse, and a boat ramp or launch. Additional facilities may include picnic tables, cooking grills, a designated group use area, and camp sites.

Several rivers in southeast Montana have noteworthy historical significance beyond their present day recreational values. Trappers, William Clark (Lewis \& Clark) and later steamships supplying early-day soldiers and forts all used the Yellowstone as their highway through this part of the state. Although much in the drainage has changed since then, access to the river is still guaranteed at DFWP access sites.

It is the goal of DFWP to administer FAS's by enacting good land management policies which protect vegetative and soil sources. To the degree that vegetation communities are healthy and vigorous, they will resist noxious weed encroachment. However, FAS's are a small part of a larger landscape in which, unfortunately, noxious weeds occur, and noxious weeds have been documented on FAS's in Region 7. Therefore, any noxious weed 
management should be approached on the landscape level, considering neighboring landowners, land use practices, and mechanisms of noxious weed seed dispersal. Noxious weed management strategies must take into account the natural resource and human use values of these sites.

To that end, noxious weed management on FAS's will center around maintaining healthy vegetation communities, deterring seed dispersal, and the detection and treatment of noxious weed outbreaks before they become well established. Healthy vegetation communities can be promoted by limiting excessive soil disturbance which facilitates weed establishment. Soil disturbance can be prevented by confining the use of motorized vehicles to established roads and trails and by not disturbing vegetation unnecessarily during the development of visitor use facilities. After the development of visitor use facilities, the disturbed areas will be reseeded. By restricting vehicular traffic to established routes, seed dispersal is also confined to areas where weeds can be easily detected and treated. Quick detection and treatment of small patches is the most efficient approach to manage noxious weed outbreaks. As populations increase, potential treatment methods and techniques dwindle as other considerations come into play. Given the number of FAS's in Region 7, budget and personnel constraints require the implementation of methods which maximize the ratio of successful weed management to cost. The management of noxious weeds on FAS's will be accomplished using the concept of INWM. Manual, cultural, chemical, and biological methods will all be used. Specific techniques will vary as individual circumstances require.

In the realization that effective weed management of large areas with complex landownership patterns such as river corridors is a cooperative effort, and to accomplish weed management goals (Noxious Weed Management Strategies, 2.0 of this document), the DFWP will place top priority on entering into weed management agreements with other governmental agencies, weed districts and private landowners.

The DFWP will also train and update its employees and agents in noxious weed identification, appropriate eradication methods and expand on detection and reporting of infestations on DFWP properties. For example, in managing FAS properties, the DFWP employs local residents in caretaking work at a group of sites within an area. Park caretakers are often the DFWP's first line of defense against noxious weed problems as they visit and work at the sites on a frequent basis. Weed training and updates will be included at annual caretaker meetings, which the DFWP has used for many years to disseminate information to field personnel. DFWP will also continue and expand its cooperation with local county weed control supervisors, which serve as the focal point for county-wide weed control efforts.

Lastly, the DFWP will attempt to inform the public on ways to reduce the spread of noxious weeds to and from department lands. - The DFWP will continue to promote vehicle use only on established roads and eventually signs may be developed linking this management option to helping reduce weed seed spread. Another example of public education efforts could include "inserts" into FAS guides, etc. 
FAS treatment plans, organized by major river drainage, follow. All access sites in that particular drainage will be discussed in common. Unique circumstances will be pointed out as necessary. Access sites are located on the following rivers: Yellowstone, Tongue, Powder and Missouri rivers. Additionally, FAS ponds and reservoirs will be discussed in common. Figure 4 illustrates the locations of FAS's in Region 7.

Recall that Table 2 summarizes the noxious weed species present and status for FAS's in Region 7. It should be pointed out that the estimated area (in acres) presented in Table 2 is cumulative for an entire site, since weeds are not continuously distributed throughout a FAS. That is, estimated acres of weeds along roadways are added to estimated acres in remote locations to obtain a total amount of acres. Figure 4 illustrates the location of the FAS's in Region 7.

\subsubsection{Yellowstone River Drainage}

\section{Existing Environment}

Almost 400 miles downriver from its headwaters in Yellowstone National Park, the Yellowstone River in Region 7 flows easterly from its confluence with the Bighorn River to the Montana/North Dakota border. Land ownership along the river corridor is mostly private and agriculture is the predominant land use. The river corridor is also home to the majority of the larger towns in eastern Montana, including Forsyth, Miles City, Glendive and Sidney. Federal lands also occur in proximity to the river at certain points within this reach. The Yellowstone River is nationally recognized for its natural resource values, whether for the angling, the vistas, or the unaltered river course. There are 13 FAS's on the Yellowstone in R-7, totaling approximately 602 acres. This particular stretch of the Yellowstone River logged approximately 30,330 angler-days during the 1993 angling season from March 1993 to February 1994 (where 1 angler-day is 1 angler fishing for approximately 4 hours).

The Yellowstone River corridor is seasonal or year-round habitat for an abundance of wildlife. Game and nongame species alike depend on its cottonwood riparian bottoms. All varieties of waterfowl use the Yellowstone during the breeding season and annual migrations.

Although there are 13 FAS's on the approximately 295 mile stretch of Yellowstone River in Region 7, the physical characteristics of the sites are similar enough to group together. Yellowstone River FAS's consist primarily of mainland properties in and adjacent to the Yellowstone River. Two islands are also included in this property group, Amelia Island in Treasure County and a portion of Joe's Island in Dawson County. The general land types contained in the Yellowstone FAS consist of undifferentiated river bottom lands and to a lesser degree marsh and river wash areas similar to those described previously in the section on Yellowstone River WMA's. 


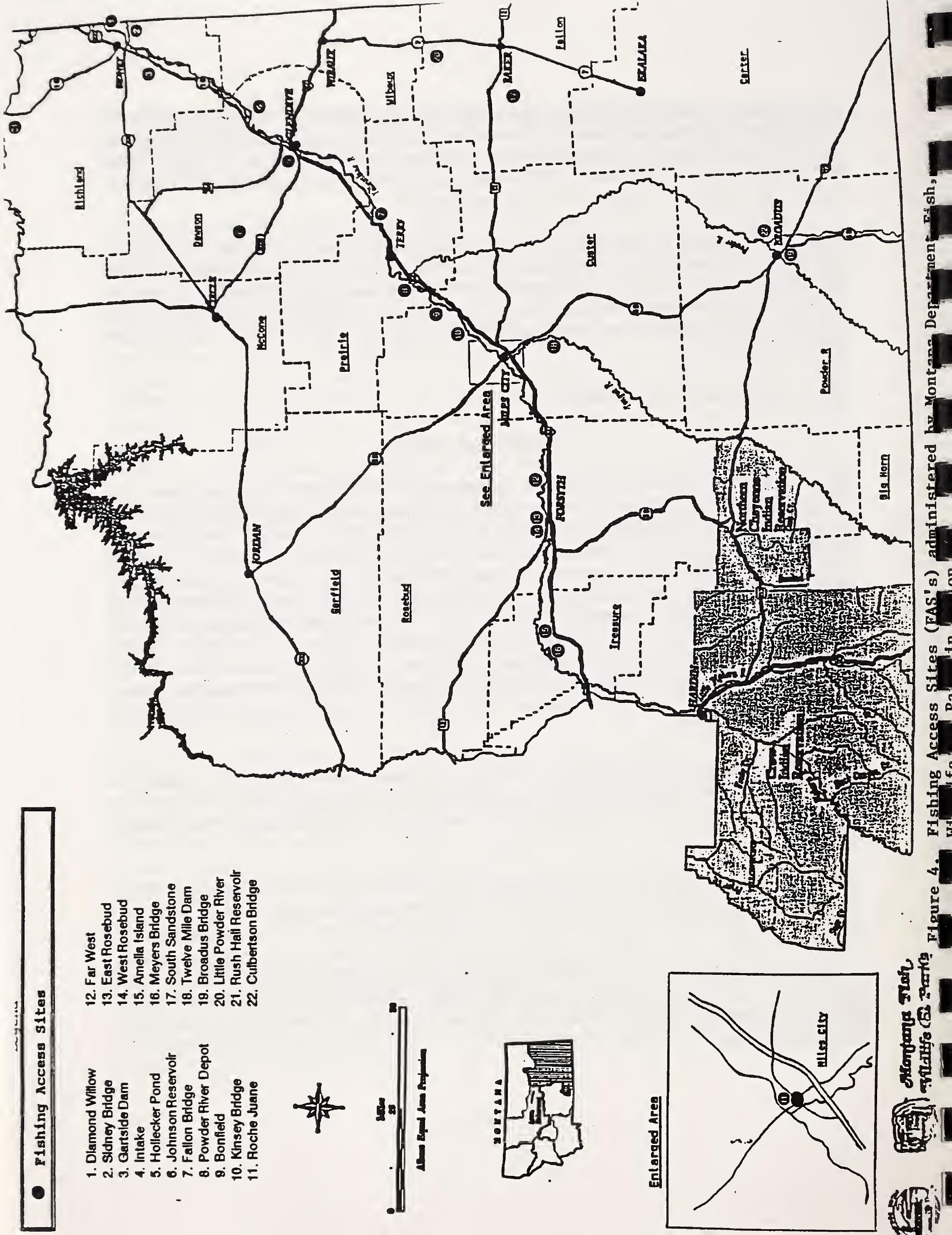


With such high resource values and the Yellowstone River's location adjacent to the majority of the population in southeastern Montana, it's only fitting that DFWP maintains the greatest number of FAS's on the Yellowstone than any other river in the Region. They are:

Meyers. Bridge

Amelia Island

Rosebud, East

Rosebud, West
Far West

Roche Jaune

Kinsey Bridge

Bonfield
Fallon Bridge

Intake

Sidney Bridge

Diamond Willow

\section{Weed Status}

The most common noxious weed species on FAS's along the Yellowstone River are Canada thistle, and Leafy spurge. Other noxious weed species include Spotted and Russian knapweed occurring in smaller patches (Table 2) on two of the sites (Meyer's Bridge and West Rosebud) and a small patch of Purple loosestrife occurs at Kinsey Bridge. Field bindweed is also known to occur at a number of FAS's (Roche Jaune, Kinsey Bridge, South Sandstone and Diamond Willow). Combinations of other weed species, including kochia, Showy milkweed and Russian thistle among others, are common on most of the sites along roadsides and in disturbed areas. The largest noxious weed populations occur at Meyer's Bridge, Kinsey Bridge, Intake and Diamond Willow FAS's.

Possible sources for weed infestations onto Yellowstone River FAS's include adjacent and upriver lands. Also the proximity of Yellowstone River FAS's to the well-travelled I-94 corridor, numerous state highways, and county roads adds to the potential spread of weeds to and from FAS sites. Another potential source for weed infestations include the active BN/Santa Fe and abandoned Milwaukee Road railroad corridors adjacent to a few FAS's.

\section{Site Constraints}

Chemical treatment of noxious weeds at all FAS's on the Yellowstone is constrained by the presence of surface waters and moderately permeable soil textures which could possibly transport chemicals to shallow, seasonal groundwater tables. Also influencing chemical use are the high levels of human use at a few sites, particularly during the summer months possibly limiting the use of chemicals even in those areas where they can be safely applied without risk to water resources. Riparian vegetation consisting of cottonwood/willow bottoms with a shrub and herbaceous understory component and numerous wetlands areas may also preclude certain chemical treatments.

\section{Weed Management Strategies and Methods}

Past weed control efforts on Yellowstone FAS's have been a combination of manual, cultural, biological and chemical treatments. Emphasis has been on chemical treatment of weeds where the appropriate site conditions exist. This has been due to relatively small size 
of the infestations and the cost effectiveness of chemical treatments. Manual and cultural methods have been applied on the majority of the FAS's on an annual basis. Hand-pulling and weed trimmers are used on small patch infestations that are noted by park personnel and roadsides have been in some instances mowed on an annual basis, helping to reduce seed head formation. Biological control agents have been released at one Yellowstone River site, Intake FAS.

As mentioned previously, past weed management efforts on Yellowstone River FAS's have focused on chemical treatments, although DFWP has begun to move away from a total reliance on chemical treatment methods on its FAS's. Chemical methods will be used for those sites (or weed patches on a site) where their application will ensure they are not transported off the target species or site (for example, by water, through soil, etc.) and will not impair site values and resources. Manual and cultural methods of weed control will continue to be used in areas that pose site constraints to chemical use, in areas of high public use such as formal campgrounds, etc. and in instances of where these methods also serve other purposes such as mowing roadsides to define road surfaces, for fire control or mowing of large camp areas. Due to the location of FAS's adjacent surface water sources and the resulting large areas where chemical use is constrained, the use of biocontrol techniques will be relied upon more in the future as biocontrol agents become more readily available through governmental and commercial sources.

In addition to treating established weeds, DFWP will attempt to curtail noxious weed spread by restricting vehicles to established roads through traffic control devices such as fences, rock barriers, etc. and by clearly designating road/trail/parking surfaces by providing signs and mowing right-of-ways. The DFWP will also monitor it's development activities before and after construction projects take place. Disturbance to soil and vegetation communities during facility development and maintenance will be minimized. Sites disturbed during development will be reseeded and closely monitored for possible weed introductions.

\subsubsection{Tongue River Drainage}

\section{Existing Environment}

The Tongue River flows almost 300 miles from its headwaters in Wyoming's Bighorn Mountains to its confluence with the Yellowstone River at Miles City. Upon exiting the Tongue River Reservoir on the Wyoming state border, the river flows through a scenic canyon area for approximately 20 miles before settling into a shallow, narrow valley to its confluence with the Yellowstone River. The primary land use is agricultural, with minor residential areas near the town of Ashland and in the immediate vicinity of Miles City. The 209 miles of river in Region 7 provided 7,030 angler days of fishing (not including the Tongue River Reservoir) in the 1993 season from March 93 to February 94. The department has one FAS on the Tongue River, 12 Mile Dam. 
12 Mile Dam FAS consists of mainland properties adjacent to the Tongue River just below the site of 12 mile Dam, a large irrigation diversion located upriver of Miles City. Land types for this area consist primarily of undifferentiated river bottom land containing riparian vegetation dominated by a Cottonwood tree overstory, tall shrubs - willow, Russian olive, and various short shrubs snowberry and wild rose. A significant feature of the property is the T\&Y diversion Dam and entrance works to the T\&Y irrigation canal, which borders the site on the eastern side. The dam, entrance works and section of canal are fenced off from the public, and are the private property of the T\&Y Ditch Company. Weed control responsibilities in this area are retained by the Ditch Company.

\section{Weed Status}

12 Mile Dam has a small infestation of Canada thistle (1/4 acre), and has patches of other weed species most notably Showy milkweed and Curly dock. Possible sources for weed infestations onto 12 Mile Dam FAS include adjacent and upriver lands and the proximity of the site to a well-traveled county road connecting Ashland to Miles City. The property is bordered to the east by a number of residential sites and by the T\&Y diversion entrance works and irrigation canal, both of which, if lacking adequate noxious weed management efforts, could serve as potential sources of noxious weed seeds for 12 Dam and the river corridor.

\section{Site Constraints}

Chemical treatment of noxious weeds at 12 Mile Dam is constrained by the presence of surface waters and by moderately permeable soil textures which could transport chemicals to shallow, seasonal groundwater tables. Riparian vegetation consisting of cottonwood and willow bottoms with a shrub and herbaceous understory component and wetlands areas may also preclude certain chemical treatments.

\section{Weed Management Strategies and Methods}

Manual and cultural methods have been applied on this site regularly in the past. Handpulling, cutting and mowing (usually confined to roadsides and camp areas) were administered at least once during any one growing season and this will continue. Chemical control of Canada thistle has occurred on an intermittent basis at 12 Mile Dam and will continue in areas appropriate for chemical use. Although no biological control agents have been released in the past at this site, the possibility exists for their use in the control of Canada thistle.

Some weed management on 12 Mile Dam FAS has been by chemical means, although DFWP has begun to move away from a total reliance on chemical treatment methods on its FAS's. Chemical methods will be used for those sites (or weed patches on a site) where 
their application will ensure they are not transported off the target species or site (for example, by water, through soil, etc.) and will not impair site values and resources. Manual, cultural, and biological methods will be emphasized on areas unsuitable for chemical treatments.

In addition to treating established weeds, DFWP will attempt to curtail noxious weed spread by restricting vehicles to established roads through traffic control devices such as rock barriers. Disturbance to soil and vegetation communities during facility development and maintenance will be minimized. Sites disturbed during facility development will be reseeded.

\subsubsection{Powder River Drainage}

The Powder River originates in Wyoming, draining the Southeast flank of the Bighorn Mountains and a large prairie basin area stretching as far south as Casper, WY. Upon entering Montana, it flows north some 217 miles to meet the Yellowstone River near the town of Terry. The Powder River provided an estimated 598 angler days in the 1993 season. In addition to it's fishery values, the Powder River corridor is also home to an abundance of big game, upland bird and nongame species. Riparian zones vegetated with cottonwood, willow, and various shrubs provide cover for deer and wild turkey among others, providing a wealth of hunting opportunities.

Land types for this area consist primarily of undifferentiated river bottom land containing riparian vegetation dominated by a Cottonwood tree overstory, tall shrubs - willow, Russian olive, and various short shrubs- snowberry and wild rose.

There are three DFWP access sites located on the river: 1) Little Powder River, 2) Broadus Bridge and 3) Powder River Depot.

As noted earlier in this document, at Little Powder River FAS, which is leased by the DFWP, the lessor has retained the responsibility for weed control. Therefore, discussion will be limited to the two remaining sites.

\section{Existing Environment and Weed Status}

It is unknown if noxious weeds are present at the small undeveloped site (2.9 acres) of Broadus Bridge FAS, a MDOT lease of the Mt. Highway 59 bridge right-of-way immediately south of Broadus. Except for boundary fencing, the site lacks any developments including signs marking the site. Because of this and the relative remoteness of the site, it is estimated the site receives very little visitation at the present time. The site is surrounded by private agricultural lands. Possible sources of weed infestation include adjacent and upriver properties and the proximity of this site to Montana Highway 59. 
At the historic site of Powder River Depot FAS, the DFWP leases a road easement through BLM and private property (approximately 3 acres in size). The site, where the Powder empties into the Yellowstone River, was one of General Alfred Terry's supply depots during his campaign against the Sioux and Cheyenne Indians in 1876. It was here that Custer's 7th Calvary loaded supplies onto mules before riding to the Battle of the Little Bighorn.

Adjacent landowners to the site include private agriculture, BN/Santa Fe Railroad, BLM and DNRC. Developments include boundary fencing and entrance signs. The easement and surrounding area has a large infestation of Leafy spurge. Possible sources for weed infestations onto Powder River Depot FAS include adjacent and upriver lands, it is a well known fact that the Powder River corridor has extensive infestations of Leafy spurge. The proximity of the site to US Highway 10 and the BN/Santa Fe Railroad corridor could serve as potential sources of noxious weed infestation to and from the site.

\section{$\underline{\text { Site Constraints }}$}

Chemical treatment of noxious weeds on Powder River FAS's is constrained by the presence of surface waters and by moderately permeable soil textures which could transport chemicals to shallow, seasonal groundwater tables. Riparian vegetation consisting of cottonwood/willow bottoms with a shrub and herbaceous understory component may also preclude certain chemical treatments.

\section{Weed Management Strategies and Methods}

At the Broadus Bridge FAS, there is the immediate need for a weed survey of the site. Although no noxious weed infestations have been reported or documented since the DFWP leased the site, the potential exists as outlined in the previous section. If needed, control efforts will be a mix of manual, cultural, biological and chemical methods.

Past weed control efforts at Powder River Depot have focused on chemical treatments primarily on BLM ground (and FWP lease inclusion). These have occurred for the most part, on an annual basis by the BLM with some contributions by the DFWP. These treatments will continue with more cooperative efforts from the DFWP.

For both FAS's chemical methods will be used (or weed patches on a site) where their application will ensure they are not transported off the target species or site (for example, by water, through soil, etc.) and will not impair site values and resources. Manual, cultural, and biological methods. will be emphasized on areas unsuitable for chemical treatments.

In addition to treating established weeds, DFWP will attempt to curtail noxious weed spread by restricting vehicles to established roads through traffic control devices such as rock barriers. Disturbance to soil and vegetation communities during facility development and maintenance will be minimized. Sites disturbed during facility development will be reseeded. 


\subsubsection{Missouri River Drainage}

\section{Existing Environment}

The Missouri River (and Fort Peck Reservoir) forms the northern boundary of DFWP Region 7 in Garfield and Richland counties. Below Fort Peck Reservoir the river flows more than 185 miles to the North Dakota border. Upon exiting the Fort Peck Reservoir the river flows through a wide valley area. The primary land use is agricultural, with population centers near the town of Wolf Point, Poplar and Culbertson. The 185 miles of river in Region 7 provided 4,022 angler days of fishing (not including the Fort Peck Reservoir) in the 1993 season from March 93 to February 94. Region 7 has one FAS on the Missouri River, Culbertson Bridge.

Culbertson Bridge FAS is a 1.35 acre MDOT highway bridge lease located south of the city of Culbertson where Mt. Highway 16 crosses the Missouri River. The site is on the south side of the river and bordered by private agricultural lands and the Mt. Highway 16 right of way. Land types for this area consist primarily of undifferentiated river bottom land containing riparian vegetation dominated by a Cottonwood tree overstory, tall shrubs willow, Russian olive, and various short shrubs snowberry and wild rose. Improvements at the site include a boat ramp and small parking area, and signs marking the site.

\section{Weed Status}

As of this date, Culbertson Bridge FAS has not been surveyed for noxious weeds and it is not known if noxious weeds exist on the property. Possible sources of weed infestation include adjacent and upriver properties and the proximity of this site to Montana Highway 16.

\section{Site Constraints}

Chemical treatment of noxious weeds at Culbertson Bridge is constrained by the presence of surface waters and by moderately permeable soil textures which could transport chemicals to shallow, seasonal groundwater tables. Riparian vegetation consisting of cottonwood/willow bottoms with a shrub and herbaceous understory component and wetlands areas may also preclude certain chemical treatments.

\section{Weed Management Strategies and Methods}

At Culbertson Bridge FAS, there is the immediate need for a weed survey of the site. Although no noxious weed infestations have been reported or documented since the DFWP leased the site, the potential exists as outlined in the previous section. If needed, control efforts will be a mix of manual, cultural, biological and chemical methods. 
Chemical methods will be used for those sites (or weed patches on a site) where their application will ensure they are not transported off the target species or site (for example, by water, through soil, etc.) and will not impair site values and resources. Manual, cultural, and biological methods will be emphasized on areas unsuitable for chemical treatments.

In addition to treating established weeds, DFWP will attempt to curtail noxious weed spread by restricting vehicles to established roads through traffic control devices such as rock barriers. Disturbance to soil and vegetation communities during facility development and maintenance will be minimized. Sites disturbed during facility development will be reseeded.

\subsubsection{Ponds and Lakes}

\section{Existing Environment}

South Sandstone Reservoir, an irrigation storage facility constructed on the S. Fork of Sandstone Creek near the town of Plevna, was acquired by the DFWP in 1975. The DFWP administers a 360 acre site with the majority in deeded land. The site has several improvements including access roads, parking areas, a boat ramp, latrines and picnic shelters and tables. South Sandstone Reservoir is surrounded on all sides by private agricultural lands and two rural county roads form the north and east boundaries of the property. Land type for this site consists of upland rangelands with vegetation predominately mid to tall grasses, forbs and shrubs. The reservoir supports a popular northern pike and walleye fishery for residents primarily from the nearby Fallon and Carter County area. Outdoor recreation opportunities associated with the Reservoir include angling, waterfowl hunting, picnicking, and wildlife viewing.

Johnson Reservoir is a small water impoundment located on Deer Creek north of Lindsay. The DFWP leases the 60 acre site from the DNRC, which includes a narrow perimeter strip around the reservoir, a parking lot and the dam outlet area. The DFWP has responsibility for weed control on that portion. The site is surrounded on all sides by private agricultural lands. Land type for this site consists of upland rangelands with vegetation predominately mid to tall grasses, forbs and shrubs. The site has minimal improvements including an access road and fenced parking area. Outdoor recreation opportunities include angling, waterfowl hunting, wildlife viewing and outdoor photography.

Hollecker Pond is a small recreational impoundment located just northwest of the city of Glendive. The DFWP has a recreational lease on the site from Dawson County and the County retains responsibility for weed control. Outdoor recreation opportunities include angling, picnicking, wildlife viewing and outdoor photography. Hollecker Pond will not be discussed below due to the Dawson County responsibility for weed control. 
Gartside Dam is a recreational impoundment located at the lower end of the Crane Creek drainage, west of the community of Crane. The DFWP owns half and leases half of the 160 acre site from the DNRC. The site is surrounded on all sides by private agricultural lands. Land type for this site consists of upland rangelands with vegetation predominately mid to tall grasses, forbs and shrubs. The site has minimal improvements which are located adjacent to the reservoir and include, an access road, latrines, two picnic shelters and tables.

Rush Hall Reservoir is a small livestock water impoundment located in the Cabin Creek drainage north of Baker. The DFWP leases this site and the private owner retains responsibility for weed control. The lease stipulates seasonal public access from approximately January to October of the year, essentially limiting the public to angling, wildlife viewing and outdoor photography use of the reservoir. Rush Hall will not be discussed below due to the lessors' responsibility for weed control.

\section{Weed Status}

Small, low-density infestations of Canada thistle occur at both South Sandstone Reservoir and Gartside Dam. In addition, South Sandstone has a small infestation of Field Bindweed. Johnson Reservoir was recently brought back as a DFWP FAS due to the rebuilding of the dam. The site has not been inventoried for weeds as of this date.

\section{Site Constraints}

On all three sites, chemical treatment of noxious weeds is constrained by the presence of surface waters and by soil textures of varying permeability, which could transport chemicals to shallow seasonal groundwater tables or in the instance of Gartside Dam with steep terrain partially surrounding the water body, could possibly transport chemicals to the water body by runoff events. Riparian vegetation consisting of cottonwood/willow bottoms with a shrub and herbaceous understory component may also preclude certain chemical treatments.

\section{Weed Management Strategies}

At Gartside Dam, no recent control activities have been noted on the Canada thistle patches inventoried on the site. Control efforts will be scheduled for the 96 season and will be a mix of manual, cultural, biological and chemical methods.

At Johnson Reservoir, the site will be inventoried this season (96) and if needed, control efforts will be a mixture of manual, cultural, biological and chemical methods.

At South Sandstone, the Canada thistle patches and when located Field bindweed patches, have received annual chemical treatments by Fallon County crews under contract with the DFWP. This will continue in areas appropriate for chemical use. 
Manual and cultural methods have been applied on some of these sites in the past. Handpulling and cutting treatments were usually administered at least once during any one growing season. Target weed species include Canada thistle and other weed species including kochia.

Some weed management on these sites was by chemical means, although DFWP has begun to move away from the use of chemical treatment methods on its FAS's. Chemical methods will be reserved for those sites (or weed patches on a site) where application will not impair site values and resources. Manual, cultural, biological, and chemical methods will all be used, although the first three will be emphasized.

In addition to treating established weeds, DFWP will attempt to curtail noxious weed spread by restricting vehicles to established roads through traffic control devices such as rock barriers. Disturbance to soil and vegetation communities during facility development and maintenance will be minimized. Sites disturbed during facility development will be reseeded.

\subsection{State Parks \& Administrative Sites}

\subsubsection{Introduction}

Preserved for their cultural, historical, recreational, and natural features, Montana's State Parks (SP's) add a new dimension to recreational opportunities in Montana. As a compliment to the natural resources of Montana, SP's offer visitors a glimpse into Montana's past, the discovery of unique natural landscape features and the enjoyment of leisure time spent outdoors.

In Region 7, there are 6 SP's, encompassing 13,316.5 acres. They are: Makoshika, Rosebud Battlefield, Medicine Rocks, Hell Creek, Tongue River and Pirogue Island. These properties provide natural settings to camp, hike, boat, picnic, view wildlife, take pictures, etc; however, the majority of the parks in Region 7 have a historical significance beyond their present day recreational values. For example, Rosebud Battlefield commemorates this large battle just 8 days before the Battle of the Little Bighorn. William Clark possibly stopped on Pirogue Island on their return journey through Montana. Medicine Rocks was prominent enough to warrant a special visit from Theodore Roosevelt in the late 1800's. Reaching farther back into the past, there is evidence of use of these sites by native peoples including, a pishkin or buffalo jump at Rosebud Battlefield SP and ceremonial use of Medicine Rocks SP.

The setting and visitor use facilities at a typical state park include the following: access roads, parking areas, boat ramps, restrooms, camp grounds, and picnic areas. Additional facilities may include cooking grills, a designated group use area, hiking trails, and drinking water. 
The goal of DFWP is to administer SP's by enacting good land management policies which protect vegetation and soil resources. To the degree that vegetation communities are healthy and vigorous, they will resist noxious weed encroachment. However, SP's are a small part of a larger landscape, in which unfortunately, noxious weeds occur and noxious weeds have been documented on most SP's in Region 7. DFWP is required by law to treat noxious weeds. Any NWMP undertaken should be approached at the landscape level, considering neighboring landowners, land use practices, and mechanisms of seed dispersal. Noxious weed management strategies must take into account the high natural resource and human use values of these sites. To that end, weed management in SP's will center around maintaining healthy vegetation communities, deterring seed dispersal, and the detection and treatment of noxious weed outbreaks before they become well established.

Healthy vegetation communities can be promoted by limiting excessive soil disturbance which facilitates noxious weed establishment. Soil disturbance can be prevented by confining the use of motorized vehicles to established roads and trails and by not disturbing vegetation unnecessarily during the development or maintenance of visitor use facilities. By restricting vehicular traffic to established routes, seed dispersal is also confined to areas where weeds can be easily detected and treated.

Preventing noxious weed dispersal is the ultimate goal. The mobility of our society makes that a difficult goal to attain. Quick detection and treatment of noxious weed outbreaks is the most efficient approach to managing weeds and keeping their dispersal rate at a manageable level. As weed patches increase in size, potential treatment methods and techniques dwindle as other considerations come into play. Given the amount of acreage contained within SP's in Region 7, budget and personnel constraints require the implementation of methods which maximize the ratio of successful weed management to cost. The management of noxious weeds in SP's will be accomplished using the concept of INWM. Where appropriate, chemicals will be applied. Other methods and techniques such as hand-pulling, mowing, and biological control agents will also be emphasized.

In the realization that effective weed management of large areas with complex landownership patterns is a cooperative effort, and to accomplish weed management goals (Noxious Weed Management Strategies, 2.0 of this document), the DFWP will place top priority on entering into weed management cooperative agreements with other governmental agencies, weed districts and private landowners.

The DFWP will also train/update its employees and agents in noxious weed identification, appropriate eradication methods and expand on detection and reporting of infestations on DFWP properties. Park caretakers are often the DFWP's first line of defense against noxious weed problems as they visit and work at the sites on a frequent basis. Weed training and updates will be included at annual caretaker meetings, which the DFWP has used for many years to disseminate information to field personnel. DFWP will also continue and expand its cooperation with local county weed control supervisors, which serve as a county focal point for county-wide weed control efforts. 
Lastly, the DFWP will attempt to inform the public on ways to reduce the spread of noxious weeds to and from department lands. For example, the DFWP will continue to promote vehicle use only on established roads and eventually signs may be developed linking this management option to reducing weed seed spread. Other examples of public information could include "inserts" into SP site guides/etc.

Noxious weed treatment plans for SP's follow. Makoshika, Rosebud Battlefield, Medicine Rocks, and Pirogue will be discussed individually; whereas Hell Creek and Tongue River will be discussed together. Figure 5 illustrates the locations of these parks in Region 7.

This section also discusses the State Fish Hatchery and Regional Headquarters complex (2 sites), all located near Miles City.

\subsubsection{Makoshika}

\section{Existing Environment}

Montana's largest SP sits atop pine and juniper-studded badlands formations overlooking the Yellowstone River near Glendive. To the Lakota Sioux Indians, Makoshika meant "bad earth" or "bad land". Makoshika was added to the SP system in 1953, when Dawson County donated 160 acres and leased an additional 80 acres to the then Montana Department of Highways, State Park Division. Subsequent acquisitions, the bulk coming from Dawson County and the BLM, now place the park at 8,832 acres. Of this amount, 4,174 acres are deeded land and the remaining 4,658 are leased primarily from Dawson County and the BLM.

Land ownership patterns, in and around the park, are a combination of checkerboard ownership between the park, private agriculture, Dawson County, and the BLM. Makoshika also has numerous tracts of private inholdings, most notably the Glendive Lion's Youth Camp site. Surrounding lands and private inholdings are used for livestock grazing and private recreational purposes. Within the boundaries of the park are numerous radio towers, which are leased to both public and private organizations by the DFWP and an existing powerline corridor. The BLM has completed a Management Framework Plan for the lands they manage adjacent to Makoshika. The entire park was identified as a Visual Resource Management Class II area, representing unique or quality visual elements which deserve protection to maintain the quality of existing features. 


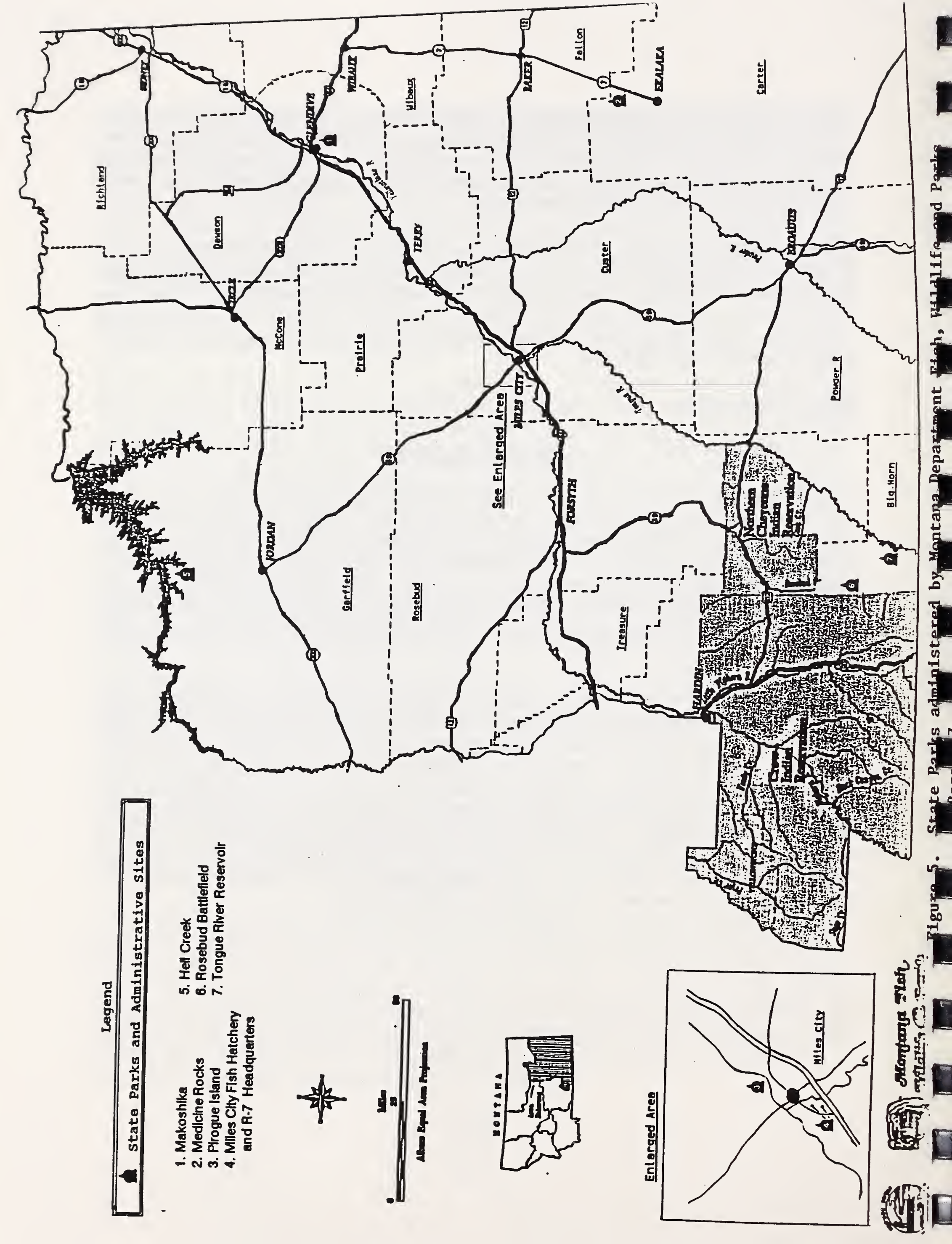


Access to Makoshika SP is provided by a county road which bisects the park from northwest to southeast. A small system of roads has been developed by the DFWP to provide access to some park features. With the completion of a visitor's center at the park in 1994, Makoshika is eastern Montana's premier park at the eastern gateway to the state along the I-94 corridor. For the calendar year of 1994, approximately 45,000 people visited Makoshika SP. Visitor use facilities include, access roads, parking areas, picnic areas, scenic turnouts, a campground, amphitheater, hiking trails, and a visitor center.

The Makoshika SP area contains intermittent Ponderosa pine and Rocky mountain juniper woodland areas, mainly confined to north-facing slopes and adjacent to coulee bottoms. Another interesting vegetative type are the hardwood draws consisting mainly of Green ash and Box elder. The majority of the vegetation is rolling grasslands covered with sagebrush, greasewood, rabbitbrush and various wheatgrassses. It is interesting to note that within these vegetative types over 225 species of wildflowers have been identified.

\section{Weed Status}

Due to Makoshika's large size (8,832 acres) and partially checkerboard land ownership pattern, weed status at the park is a complex issue. The most significant infestation is Leafy spurge. Approximately 15 acres of Leafy spurge patch infestations have been documented, although it is estimated there are many more "patches" throughout the park's back country and surrounding private and public lands. (Chuck Carbert, Park Manager, 1995). There is also a small infestation of Canada thistle and there are minor infestations of other weed species.

Although the park does not lie along any major highway routes, with its large annual visitation, there is an increased potential for noxious weed introduction and spread from Makoshika. Potential also exists for spread of weeds to and from neighboring grazing lands and private inholdings and leases including private recreational, tower lease sites and powerline corridor.

\section{Site Constraints}

Although Makoshika is primarily an dry, upland site, chemical methods of weed control are constrained by the presence of a desirable vegetation type (intermittent Ponderosa pine and Rocky mountain juniper areas) and in a few areas by riparian areas on or near various coulee bottoms and near areas were buman use is high.

\section{Weed Management Strategies and Methods}

Past weed control methods at Makoshika have been primarily chemical treatments under contract with Dawson County. The majority of the applications were on patches located close to the county road through the park. Follow-up treatments, under contract with Dawson County, will continue. The park has also been the release site for the biological 
control agent Aphthona nigriscutis on Leafy spurge. With the park's large size and backcountry areas, the potential exists for biological control methods including the continuing use of insects and the possibility of selective grazing treatments. A component of the weed control plan for Makoshika that will be accomplished in the 96 season is a thorough weed survey of the park. Once a better picture of the weed infestation (Leafy spurge) on Makoshika and surrounding lands is known, treatment methods can be selected and prioritized. The size and remoteness of the park bring into focus the need for a cooperative effort to control spurge in this area of the county. The DFWP will investigate cooperative efforts with the Dawson County Weed District, BLM and adjacent private landowners.

As DFWP has begun to move away from a total reliance on chemical treatment methods on its SP's, chemical methods will be reserved for those weed patches where application of chemicals will not impair site values and resources. Should weeds spread to areas where chemical methods are no longer appropriate, cultural, manual, and biocontrol methods will be used.

In addition to treating established weeds, DFWP will attempt to curtail noxious weed spread by restricting vehicles to established roads through traffic control devices such as rock barriers. Disturbance to soil and vegetation communities during facility development and maintenance will be minimized. Sites disturbed during facility development will be reseeded.

\subsubsection{Rosebud Battlefield}

\section{Existing Environment}

On June 17, 1876, over 1300 soldiers, scouts and miners were met in battle by an equal number of Sioux and Cheyenne warriors. These rocky outcroppings overlooking Rosebud Creek were the setting for one of the most intense battles ever waged between Native Americans and the US Army under the leadership of General George Crook. The Indian victory at Rosebud was a prelude to and directly led to a still greater victory 8 days later on June 25, 1876, when LT. Col. George A. Custer and his immediate command was wiped out to a man by these same warriors who opposed Crook on the Rosebud. In addition to the historical significance of the site the land is abundant in archeological remains. These include a 3,500 - 4,000 year old buffalo jump with man-made drive lines marked by rock cairns and some rare petroglyphs.

Rosebud Battlefield was added to the SP system in 1978 when the state purchased the battlefield with coal tax revenues. It is comprised of 3,052 acres of deeded land; land ownership surrounding the park is privately owned agricultural lands in a checkerboard pattern, with livestock grazing and production of hay the primary crops. To improve 
rangeland health and enhance wildlife habitat on Rosebud Battlefield SP, a rest-rotation grazing system plan was instituted and is carried out by a private grazing lease. Access to the park is provided by a county road which heads west from County Highway \#314, approximately 20 miles north of Decker.

The majority of Rosebud Battlefield. SP consists of sedimentary uplands, utilized as rangeland with the majority of vegetation mid to short grasses with sagebrush, greasewood and rabbitbrush the dominant shrubs. Also included in the uplands is a small amount of intermittent Ponderosa pine/Rocky mountain juniper woodland areas, mostly confined to north-facing slopes. In the Rosebud Creek area, agricultural production of hay forage has replaced some of the riparian vegetation which includes willow, chokecherry, Green ash and various shrubs including, snowberry and rose.

For the calendar year of 1994, an estimated $1500+$ people visited Rosebud Battlefield SP. Visitor use facilities include minor access roads, including a tour loop; an information display and the historic Kobold ranch headquarters.

\section{Weed Status}

Rosebud Battlefield remains largely weed-free at the present time. A small Spotted knapweed infestation of about $1 / 8$ acre, occurs near the battlefield loop road. Dalmatian toadflax occurs in small numbers $(X<1 / 16$ acre) in the back areas of the site near the property boundaries. An older infestation of burdock occurs along the banks of Rosebud Creek. While these infestations are relatively small, the potential for spread is possible through a grazing lease on the battlefield, park visitor use and trespass cattle problems. It should also be noted here that Black henbane has infested the road right-of-way (private road) leading to the park.

\section{Site Constraints}

Chemical methods of noxious weed treatment is constrained on those portions of the park bordering the Rosebud Creek. This is due to the presence of surface water sources and moderately permeable soils.

\section{Weed Management Strategies and Methods}

In the past, chemical control treatments have been applied to this site on a regular basis, primarily targeting the burdock infestation. The small Spotted knapweed patch was completely pulled in 1995 and will be monitored and treated if necessary in future years. The small Dalmatian toadflax patches noted in a 1995 field survey will also be monitored and treated in future years. Past year's weed control efforts at the Battlefield have been performed by Big Horn County and DFWP crews. The current grazing lease at the site provides for weed control activities to be carried out by the lessee. 
As DFWP has begun to move away from a total reliance on chemical treatment methods on its SP's, chemical methods will be reserved for those weed patches where application of chemicals will not impair site values and resources. Should weeds spread to areas where chemical methods are not appropriate, cultural, manual, and biocontrol methods will be used.

In addition to treating established weeds, DFWP will attempt to curtail noxious weed spread by restricting vehicles to established roads through traffic control devices such as rock barriers. Disturbance to soil and vegetation communities during facility development and maintenance will be minimized. Sites disturbed during facility development will be reseeded.

\subsubsection{Medicine Rocks}

\section{Existing Environment}

About 60 million years ago a wide river meandered through this area. It laid down layer after layer of sand that eventually turned into fragile sandstone. Thousands of years of wind and rain created the rock formations that now jut from the rolling grass and pine covered hills of southeastern Montana that are the sandy knobs and pockmarked pillars of Medicine Rocks SP, an eastern Montana landmark. Local legends say Native Americans considered the rocks sacred and did medicine dances there before hunts and wars. No evidence exists to support the oldtimer's claims, although pottery and other Indian artifacts have been found among the formations.

Medicine Rocks was first added to the SP system in 1957, when Carter County donated 360 acres to the then Montana Department of Highways, State Park Division. A subsequent land disposal now places the park at 320 acres. The park is surrounded by private agricultural rangeland. This park was designated a primitive SP by the 1993 Montana legislature, a designation which limits the amount and types of development that can take place at this park. For the park season of 1994 (May - September), and estimated 5,849 people visited Medicine Rocks SP. Visitor use facilities include an access road, parking areas, campgrounds and latrines.

Land types for this site consist primarily of rangeland with short to mid grasses and various shrub sand forbs. SP developments at this site include a road system, parking areas and vault toilets.

The fragile sandy textured soil of the site erodes very easily. Off-road vehicle use and initials carved and painted on the sandstone formations have speeded erosion and destroyed thousands of years of nature's work. Off-road vehicle use also spoils the parks's natural setting and endangers the existence of 5 plant species and 2 plant community types of special concern ${ }^{1}$. These are: 
Narrow Leaf Milkweed

Smooth goosefoot

Schweinitzii flatsedge

Silky prairie clover

Moss phlox

Narrowleaf penstemon

Sand Bluestem/

Needle-and-thread

community type

Silver sagebrush/

Long stolon sedge

community type
Asclepias stenophylla

Chenopodium subglabrum

Cyperus schweinitzii

Dalea villosa

Pholx andicola

Penstemon angustifolius

Andropogon hallii/

Stipa comata
G4, S1

G4, S1

G5, S1

G5, S1

G4, S1

G5, S1

G3, S3

Artemisia cana/

Carex helophila

G3, S3

${ }^{1}$ Information provided by the Montana Natural Heritage Program (February 1995).

\section{Weed Status}

At the present time, the site remains relatively weed-free. A small infestation of Canada thistle exists near a riparian area at the northeast corner of the site.

\section{Site Constraints}

Chemical treatment of noxious weeds on this site is constrained near riparian areas and throughout the site due to the presence of plant species and community types of special concern. Chemical treatments are also constrained in developed areas by high levels of human use, particularly during the summer months.

\section{Weed Management Strategies and Methods}

In the past, weed management at Medicine Rocks has been a combination of pulling, mowing, and chemical means primarily targeted along road right-of-ways throughout the park. Future management practices will continue to use the same methods along roadways. In regards to the Canada thistle patch near a riparian area the possibility exists for the use of biological control methods. Throughout the remainder of the dry upland areas of the site a different strategy must be employed. First, the locations of the species and community types of special concern must be located on the site. Once those locations have been determined, weed control in/near these areas will be by manual or biological methods, probably by pulling or spot cutting areas. All areas located away from these will be considered for control by chemical means due to the anticipated small size of the potential infestations. 
As DFWP has begun to move away from a total reliance on chemical treatments on its SP's, chemical methods will be reserved for those weed patches occurring in open areas where application of chemicals will not impair other site values and resources. Other methods such as cultural, manual, and biocontrol will be applied elsewhere.

In addition to treating established weeds, DFWP will attempt to curtail noxious weed spread by restricting vehicles to established roads through traffic control devices such as rock barriers. Disturbance to soil and vegetation communities during facility development and maintenance will be minimized. Sites disturbed during facility development will be reseeded.

\subsubsection{Pirogue Island}

\section{Existing Environments}

William Clark (of Lewis and Clark) might have camped on or near this island during the course of his return trip east in 1806. Pirogue Island SP consists of a 200 acre island in the Yellowstone River, several small outer islands and 10 acres on the mainland. It is located approximately 5 miles northeast of Miles City and offers residents and visitors access to the river for fishing, wildlife viewing, bowhunting, boating, hiking and wildlife photography. The large island is accessible by vehicle during times of low water; the smaller islands are accessible only by boat. It is estimated approximately 3,628 people visited the park between May 15 and September 15, 1994. Visitor facilities include access roads and parking areas. This park was designated a primitive SP by the 1993 Montana legislature, a designation which limits the amount and types of development that can take place at this park.

Land types for this area consist primarily of undifferentiated river bottom land containing riparian vegetation dominated by a cottonwood tree overstory, tall shrubs (primarily willow) and various short shrubs (snowberry and wild rose). On the main island, a large open area previously cultivated and seeded for hay production, is slowly reverting back to native vegetation. SP developments at this site include an access road and parking areas.

\section{Weed Status}

Noxious weeds at Pirogue Island SP include, Leafy spurge, Spotted knapweed, Canada thistle and other weed species such as Curly cup and kochia. Leafy spurge is the most serious of the noxious weed species documented at this site. Spotted knapweed is largely confined to a patch on the outer island, and Canada thistle is near riparian areas and is difficult to treat.

There is the potential for further spread of weeds, primarily Leafy spurge, throughout this site and possibly off-site, through the proliferation of vehicle trails and off-designated roads which vehicle use. Gratefully, one factor to counter the potential for weed spread at Pirogue Island is the relatively small visitation the site receives. 


\section{$\underline{\text { Site Constraints }}$}

Chemical methods of noxious weed treatment at Pirogue Island SP is constrained by the presence of surface water, moderately rapid soil textures and seasonal (work) vehicle access. Other constraints include a cottonwood overstory vegetation component in areas that are infested with Leafy spurge and riparian habitat infested with Canada thistle.

\section{Weed Management Strategies and Methods}

In the past, weed management at Pirogue Island has been largely through the use of chemical methods targeted at the Leafy spurge infestation. This has resulted in the spurge infestation being contained into large patches surrounded by relatively weed-free areas. The park has also been the site of release of the biological control agent Aphthona nigriscutis, (flea beetles) on Leafy spurge. Chemical control will remain the primary method of control of spurge in the appropriate areas. In site-constrained areas, control methods will center on biological methods. In regards to the Spotted knapweed infestation on one of the outer islands, manual and biological control methods will be emphasized. For the Canada thistle infestation located in a riparian area, biological control methods will be considered if it proves feasible.

As DFWP has begun to move away from a total reliance on chemical treatment methods on its SP's, chemical methods will be reserved for those weed patches where application of chemicals will not impair site values and resources. Should weeds spread to areas where chemical methods are not appropriate, cultural, manual, and biocontrol methods will be used.

In addition to treating established weeds, DFWP will attempt to curtail noxious weed spread by restricting vehicles to established roads through traffic control devices such as rock barriers. Disturbance to soil and vegetation communities during facility development and maintenance will be minimized. Sites disturbed during facility development will be reseeded.

\subsubsection{Tongue River State Park}

\section{Existing Environment}

Tongue River SP is a DNRC lease along the western shore of the Tongue River Reservoir that dates back to 1983. A total of 642 acres is leased in this area by the DFWP, including a small 1.86 acre lease from Decker Coal. An additional 43.1 acres leased from the DNRC and referred to as "Pike Marsh" has been included with Tongue River SP for the purposes of this report. This area is located at the upper end of the reservoir and was originally envisioned as a field hatchery location for pike fry, although the site proved unsuitable and was abandoned for this use. Now it serves as a wetland habitat area for waterfowl. 
Tongue River SP is an impoundment of the Tongue River and is located approximately 5 miles north of the community of Decker. Land ownership and uses immediately surrounding the park are private, with the majority of the lands devoted to livestock grazing and a few parcels of residential holdings. In addition, the park shares a boundary with two small parcels of Northern Cheyenne tribal lands.

The park provides an outstanding variety of warm water fishing opportunities, drawing visitors from a large regional area (approximately 300 miles in diameter from the Laurel and Billings area to Gillette and Sheridan, WY). The majority of visitors to the park come to fish for crappie, walleye and bass and due to the remote location of the park stay to camp. Warm reservoir water temperatures in the late summer bring many to the park for waterbased activities including pleasure boating, swimming, waterskiing, etc. For the calendar year of 1994, there were approximately 30,000 visitors to Tongue River SP.

Access to Tongue River SP is provided by a county road which exits Big Horn Co. Highway \#314 approximately 5 miles north of Decker and runs north along the Tongue River all the way to Ashland some $40+$ miles distant. Where the road runs along the western shore of the Tongue River Reservoir it roughly forms the western boundary of the park. The park consists of lands along the western shore of the reservoir that are contained on primarily four large peninsulas. While the DNRC, for purposes of reservoir management, claims all lands along the reservoir shoreline (below a specific "take" elevation) DFWP retains management control responsibilities on specific areas, which as mentioned earlier, total approximately 642 acres.

Recreational developments and facilities are concentrated on the four peninsula areas consisting largely of primitive roads and campground facilities including picnic tables, firepits, trash receptacles, pit-vault latrines and a few picnic shelter structures. Tongue River SP also has a main boat ramp area featuring a full-service private marina and store.

The Tongue River SP area contains vegetation types ranging from relatively dry mid-grass prairie and coniferous forest dominated by Rocky mountain juniper and Ponderosa pine to moisture-dependent riparian forest vegetated by cottonwood, Green ash and Box elder with a diversity of deciduous shrubs and herbaceous species adapted to moist growing conditions. The Pike Marsh area, and intermittent marshy area located at the upper end of the reservoir consists of riparian vegetation including cottonwoods, various willows, sedges and prairie cordgrass.

\section{Weed Status}

At the present time, there are no noxious weed infestations noted on Tongue River SP property. However, there are other weed species present which include Ox-eye daisy, Common mullein, Curlycup gumweed, and Russian thistle. Curlycup gumweed and kochia are persistent weeds found primarily on road surface edges throughout the park. Ox-eye daisy has been found west of the entrance road to. Rattlesnake Campground. Common 
mullein has infested the campground area located below the Tongue River Dam site. Also infesting the Big Horn County road right-of-way through the park is black henbane. As of this date the Pike Marsh property located at the upper end of the reservoir has not been surveyed for noxious weeds and it is not known if noxious weeds exist on the property. It should be noted that small populations of salt-cedar or tamarisk have been found on the reservoir margin and could pose control problems in the future.

In regards to the potential for noxious weed introduction and spread from Tongue River SP, a number factors exist now to increase the potential. These include a county road along the entire western boundary of the park, large annual visitation at the park, and a shared reservoir shoreline with other property owners including a large coal strip-mine with the possibility of weed seed transport by reservoir waters.

It should also be noted here that two future construction projects will figure significantly in the potential for weed spread on and off the reservoir area. Those projects are: 1) the Tongue River Dam rebuild (part of the Tongue River Basin Project) and 2) the rebuilding of Tongue River SP, following the dam rebuild and subsequent raising of the reservoir's water level. Increased reservoir levels and a change in the reservoir's wetted perimeter could possibly open new areas (bare ground) to noxious weed infestation. The two construction projects will disturb large amounts of ground, also opening new areas to noxious weed infestation. It is beyond the scope of this document to assess the impacts from these two projects and has been mentioned here to list a future impact to this site.

\section{Site Constraints}

At Tongue River SP chemical treatment of noxious weeds is constrained by the presence of surface waters and by soil textures of varying permeability, which could transport chemicals to shallow seasonal groundwater tables, or in the instance of steep upgrade terrain and coulee areas, could possibly transport chemicals to the water body by runoff events. Chemical treatments are also constrained in developed areas by high levels of human use, particularly during the summer months. Riparian vegetation at the edge of the reservoir may also preclude certain chemical treatments.

\section{Weed Management Strategies and Methods}

Control of other weed species infesting roadsides within the park, including Ox-eye daisy, Curlycup gumweed and Russian thistle, has been through primarily manual and cultural. Some past control has also been by chemical treatments. Both methods have been applied intermittently in the past and future treatments will be on an annual basis. Control methods on Common mullein infesting a large area of the SP campground below the dam have been through manual and cultural treatments. These methods will continue to be used in this high visitor-use area. If the appropriate conditions exist, chemical treatments will be considered. 
As DFWP has begun to move away from a total reliance on chemical treatment methods on its SP's, chemical methods will be reserved for those weed patches where application of chemicals will not impair site values and resources. Should weeds spread to areas where chemical methods are not appropriate, cultural, manual, and biocontrol methods will be used.

In addition to treating established weeds, DFWP will attempt to curtail noxious weed spread by restricting vehicles to established roads through traffic control devices such as rock barriers. Disturbance to soil and vegetation communities during facility development and maintenance will be minimized. Sites disturbed during facility development will be reseeded.

\subsubsection{Hell Creek State Park}

\section{Existing Environment}

Hell Creek SP is a Army Corps of Engineers (COE) lease on the south shore of the Fort Peck Reservoir, 26 miles north of Jordan. The lease dates back to the 1950's and is a total of 260 acres in size. Land ownership and uses immediately surrounding the park include the Charles M. Russell National Wildlife Refuge (CMR NWR), which also allows livestock grazing in this area and a COE cabin site area north of the park. The Reservoir/CMR NWR is well known for its excellent fishing and hunting opportunities. Camping, pleasure boating, waterskiing, hiking, wildlife viewing and photography are also popular pursuits. Hell Creek serves as a gateway into this large remote Missouri Breaks country.

Access to the park is provided by a county road which runs 26 miles north to the site from Jordan. Facilities include a small developed road system, three boat ramps and campground facilities including a flush toilet building, picnic shelters and tables and a group use building. Hell Creek SP also features a full-service private marina and store. For the calendar year of 1994, it is estimated there were over 3,000 visitors to Hell Creek SP.

The Hell Creek SP area consists of sedimentary uplands adjacent to the reservoir. Vegetation types range from Ponderosa pine and Rocky mountain juniper clad hills and coulees to rolling grassland areas which eventually drop to the reservoirs edge. Grassland species include mid to short grasses with sagebrush, greasewood and rabbitbrush the dominant shrubs. At the edge of the reservoir riparian vegetation has emerged in areas following the intermittent water levels and sub irrigated areas.

\section{Weed Status}

Small patches of Canada thistle infestations exist near the reservoir edge. These persistent infestations have grown and receded over the years dependent primarily on reservoir levels, with the seed source for these infestations believed to be carried by the reservoir waters. Other weed species present include kochia and Curlycup gumweed, found along roadsides 
in the park. Also observed in 1995, was a very small infestation of Common toadflax, uphill from the Milroy's Cove Campground area and west of the county road. Potential sources of weed infestation to the site include the Hell Creek bottom immediately upstream from the site, the county road which bisects the site from $N>S$ and as mentioned earlier weed seed transported on the reservoir waters. Weed infestations known to occur in nearby areas include an infestation of Salt cedar at the mouth of Hell Creek and the reservoir, and an infestation of Spotted knapweed located on the upper reaches of Hell Creek.

\section{Site Constraints}

At Hell Creek SP chemical treatment of noxious weeds is constrained by the presence of surface waters and by soil textures of varying permeability, which could transport chemicals to shallow seasonal groundwater tables or in the instance of steep upgrade terrain and coulee areas could possibly transport chemicals to the water body by runoff events. Chemical treatments are also constrained in developed areas by high levels of human use, particularly during the summer months. Riparian vegetation at the edge of the reservoir may also preclude certain chemical treatments.

\section{Weed Management Strategies and Methods}

The DFWP has intermittently sprayed the Canada thistle patches in areas appropriate for chemical use and has annually mowed the patches closer to the reservoir edge to reduce seed head formation and reduce problems with public use of the areas. These treatment methods will continue with the possible introduction of a biological control agent on isolated patches near the waters edge. For the other weed species infesting roadsides within the park, mowing and grading have helped reduce seed head formation and these road maintenance activities will continue on an annual basis. The patch of Common toadflax will be monitored and treated. Manual and chemical treatments will be considered in the appropriate areas.

As DFWP has begun to move away from a total reliance on chemical treatment methods on its SP's, chemical methods will be reserved for those weed patches where application of chemicals will not impair site values and resources. Should weeds spread to areas where chemical methods are not appropriate, cultural, manual, and biocontrol methods will be used.

In addition to treating established weeds, DFWP will attempt to curtail noxious weed spread by restricting vehicles to established roads through traffic control devices such as rock barriers. Disturbance to soil and vegetation communities during facility development and maintenance will be minimized. Sites disturbed during facility development will be reseeded. 


\subsubsection{Miles City Fish Hatchery}

The Miles City Fish Hatchery serves as the only warm water fish hatchery for the State of Montana. Acquisition of the site began in 1958 and today the site totals 245.6 acres, almost all of it in deeded land. The Hatchery site shares a boundary on the south side with I-94, to the west with the Miles City I-94 business loop and the Fort Keogh Agriculture Experiment Station, to the north BN/Santa Fe Railroad and the east with private rangeland and the Spotted Eagle recreation area managed by the City of Miles City and Custer County.

\section{Existing Environment}

The site consists of the hatchery building complex comprised of 6 buildings (including two residences) and 12 outdoor rearing ponds. A small road system connects the building complex to the ponds area. Vegetation types include rangeland consisting of short and mid grass species with sagebrush, greasewood and rabbitbrush the dominant shrubs.

\section{Weed Status}

At the present time, there are no noxious weed infestations noted on Hatchery property. However, there are other weed species present which include kochia and Russian thistle along roadsides and in disturbed areas near pond and their filling/outlet works. Potential sources of weed infestations include the normal hatchery operations, such as vehicle traffic and picking up/delivering fish to widely scattered points all across eastern Montana. Potential sources of weed infestation also exist from the I-94 and BN/Santa Fe Railroad corridors, and the private rangeland and Spotted Eagle areas.

\section{Site Constraints}

Chemical treatment of noxious weeds is constrained by the presence of surface waters and by soil textures of varying permeability, which could transport chemicals to shallow seasonal groundwater tables or in the instance of areas immediately upgrade of pond areas could possibly transport chemicals to the water body by runoff events.

\section{Weed Management Strategies and Methods}

Manual and cultural control methods have been the primary control methods used to control kochia and Russian thistle along roadsides and in disturbed areas. This has been on an annual basis and will continue in the future. Also, spot chemical treatments were used on an intermittent basis in the past and treatments will continue in those areas appropriate for chemical use. 
It is also recognized that weed infestations could be spread to and from the hatchery site by vehicle traffic during the course of delivering fish to remote sites throughout eastern Montana. To reduce the risk of this (in addition to controlling weeds on the hatchery site), the DFWP will also train and update its employees and agents in noxious weed identification. By avoiding vehicle travel through infestations whenever possible or by thoroughly cleaning or washing trucks that have had to travel through infestations, the spread of weeds can be reduced. Weed training and updates will be included at annual meetings, which the DFWP has used for many years to disseminate information to field personnel. DFWP will continue to expand its cooperation with local county weed control supervisors, which serve as a county focal point for county-wide weed control efforts.

As DFWP has begun to move away from a total reliance on chemical treatment methods on its SP's, chemical methods will be reserved for those weed patches where application of chemicals will not impair site values and resources. Should weeds spread to areas where chemical methods are not appropriate, cultural, manual, and biocontrol methods will be used.

In addition to treating established weeds, DFWP will attempt to curtail noxious weed spread by restricting vehicles to established roads through traffic control devices such as rock barriers. Disturbance to soil and vegetation communities during facility development and maintenance will be minimized; sites disturbed will be reseeded.

\subsubsection{Region Seven Administrative Sites}

\section{Existing Environment}

Administrative sites are those reserved for use by DFWP. The Regional Administrative Sites are located on the western edge of Miles City, totalling 7.6 acres. This complex of two sites serves as the public office and visitor center of DFWP and as a parking/storage facility for vehicles, trailers, and heavy equipment.

\section{Weed Status}

Because vehicles are one agent of weed seed dispersal, occasionally a noxious weed will root in the parking lot or storage compound of the Regional Headquarters. No weeds have been detected at both sites.

\section{Weed Management Strategies and Methods}

Any noxious weeds discovered in the Headquarters complex are pulled immediately; however, noxious weeds may appear sometime in the future. Should weed treatment become necessary, any of the four treatment methods (manual, cultural, chemical, or biological) may be used, depending on the circumstances. Any weed management actions will be conducted subject to the guidelines presented in this Plan. 
As DFWP has begun to move away from a total reliance on chemical treatment methods on its SP's, chemical methods will be reserved for those weed patches where application of chemicals will not impair site values and resources. Should weeds spread to areas where chemical methods are not appropriate, cultural, manual, and biocontrol methods will be used.

In addition to treating established weeds, DFWP will attempt to curtail noxious weed spread by restricting vehicles to established roads through traffic control devices such as rock barriers. Disturbance to soil and vegetation communities during facility development and maintenance will be minimized. Sites disturbed during facility development will be reseeded. 


\subsection{REFERENCES}

Barnick, J. 1995-6. Big Horn County Weed District Supervisor. Personal communications with J.W. Dean and M.L. Hathaway.

Bighorn County Weed Control District. 1995. Summary list of Noxious weed species. Hardin, Montana.

Brence, L. 1996. Treasure County Weed District Superviosr, Personal communications with M.L. Hathaway.

Bruha, D. 1995-6. Fallon County Weed District Superviosr, Personal communications with J.W. Dean.

Carter County Weed Control District. 1995. Summary list of noxious weed species. Ekalaka, Montana.

Conklin D. 1984. Makoshika State Park Management Plan. Montana Department Fish, Wildlife and Parks Files.

Corps of Engineers. 1992. Master Plan Update, Fort Peck Dam/Fort Peck Lake, Missouri River, Montana. U.S. Department of the Army, Corps of Engineers. Omaha District.

Custer County Weed Control District. 1995. Summary list of noxious weed species. Miles City, Montana.

Dawson County Weed Control District. 1995. Summary list of noxious weed species. Glendive, Montana.

Dobkin, D. S. 1992. Neotropical migrant landbirds in the Northern Rockie and Great Plains. U.S. Department of Agriculture Forest Service Northern Region. Publication no. R1-93-34. Missoula, Montana.

Donvan C. 1996. Richland County Weed District Superviosr, Personal communications with J.W. Dean.

Fallon County Weed Control District. 1995. Summary list of noxious weed species. Baker, Montana.

Flath, D. 1995. Non-Game Coordinator for the Montana Department of Fish, Wildlife and Parks. Personal communication with N.S. Martin, Montana Department of Fish, Wildlife and Parks. 
Garfield County Weed Control District. 1995. Summary list of noxious weed species. Jordan, Montana.

Heidel, B. 1993. Botanist with the Montana Natural Heritage Program. Personal communication with Carolyn Sime, Montana Department of Fish, Wildlife and Parks.

Konizeski, D. 1982. The Montanan's Fishing Guide, Volume II. Revised and Updated by J.A. Derleth. Mountain Press Publishing Company. Missoula, Montana. 307pp.

Johnson, J.L. and R.D. Pfister. 1981. Survey of potential ecological natural landmarks of the northern rocky mountains. IFRES U.S. Department of Agriculture Forest Service. MT-25.

Jorgenson, H. 1993. Plant Ecologist for the Montana Department of Fish, Wildlife and Parks. Personal communication with Carolyn Sime, Montana Department of Fish, Wildlife and Parks.

Lacey, C. 1991. Groundwater and agrichemical protection pilot project. Unpubl. report and maps prepared for Lewis and Clark County Conservation District.

Lessica, P. 1993. Botanist. Missoula, Montana. Personal communication with Carolyn Sime, Montana Department of Fish, Wildlife and Parks.

Lolo National Forest. 1989. Noxious weed management draft environmental impact statement, amendment to the Lolo National Forest Plan. U.S. Department of Agriculture, Lolo National Forest. Missoula, Montana.

Manoukian, M. 1996. Prairie County Weed District Superviosr, Personal communications with J.W. Dean.

McKenna, D. 1993. Associate Research Hydrogeologist, Montana Groundwater Assessment Program, Montana College of Mineral Science and Technology. Personal communication with Carolyn Sime, Montana Department of Fish, Wildlife and Parks.

Montana Department of Agriculture. 1991. Draft noxious weed trust fund programmatic environmental impact statement. Helena, Montana.

Montana Fish and Game Department. 1975. Inventory and plans: Game Management Areas. Montana Department of Fish, Wildlife and Parks files.

Montana Department of Fish, Wildlife and Parks. 1983. Weed control program for lands managed by the Montana Department of Fish, Wildlife and Parks. Montana Department of Fish, Wildlife and Parks files. 
Montana Department of Fish, Wildlife and Parks. 1994. Montana statewide angling pressure, 1993. Montana Department of Fish, Wildlife and Parks files.

Montana Department of Fish, Wildlife and Parks. 1977. Preliminary Wildlife Area management plan, Elk Island lands. Montana Department of Fish, Wildlife and Parks files.

Montana Department of Fish, Wildlife and Parks. 1977. Preliminary Wildlife Area management plan, Seven Sisters lands. Montana Department of Fish, Wildlife and Parks files.

Montana Department of Fish, Wildlife and Parks. 1992. Creating a Vision for the future. Montana Department of Fish, Wildlife and Parks files, Helena.

Montana Department of Fish, Wildlife and Parks. 1994. Lands inventory. Montana Department of Fish, Wildlife and Parks Lands Section files, Helena.

Montana Department of Fish, Wildlife and Parks. 1993. Draft integrated noxious weed management plan for Region 8. Prepared by OEA Research Inc. Helena.

Montana Department of Fish, Wildlife and Parks. 1993. Draft weed management plan for Region 2. Prepared by Land and Water Consulting Inc. Missoula.

Montana Department of Fish, Wildlife and Parks. 1993. Draft weed management plan for Region 3.

Montana Department of Fish, Wildlife and Parks. 1994. Draft weed management plan for Region 1.

Montana Natural Heritage Program. 1995. Results of a Heritage Program database search. Montana Natural Heritage Program, Helena.

Montana Department of Natural Resources and Conservation. 1995. Draft Environmental Impact Statement, Tongue River Basin Project. Montana Department of Natural Resources and Conservation. Helena, Montana.

Newby, R. 1988. Great Escapes: Montana State Parks. Falcon Press Publishing Co., Inc. 74pp.

Phillips, G. 1993. Pollution Control Biologist and Water Quality Specialist for the Montana Department of Fish, Wildlife and Parks. Personal communication with Carolyn Sime, Montana Department of Fish, Wildlife and Parks. 
Sherwood, O. 1996. Custer County Weed District Supervisor, Personal communications with J.W. Dean and M.L. Hathaway.

Thomas, V. 1996. Rosebud County Weed District Supervisor, Personal communications with M.L. Hathaway. 


\section{APPENDICES}

APPENDIX A: County Noxious Weed Control Act of 1979

APPENDIX B: Synopsis of Noxious Weed Species

APPENDIX C: Laws and Policies Relating to the Management of Noxious Weeds

APPENDIX D: Biological Control Agents Available in Montana and Those Released on Department of Fish, Wildlife and Parks Properties

APPENDIX E: Herbicide Emergency Response Plan

APPENDIX F: Sensitive Species Occurring in the Vicinity of Department of Fish, Wildlife and Parks Region 7 Properties

APPENDIX G: Herbicides Proposed for Use on Department of Fish, Wildlife and Parks Region 7 Properties

APPENDIX H: Herbicide Label Instructions and Safety Precautions 



\section{APPENDIX A}

COUNTY NOXIOUS WEED CONTROL ACT OF 1979 


\section{COUNTY NOXIOUS WEED \\ CONTROL ACT \\ AND}

\section{ADMINISTRATIVE RULES}

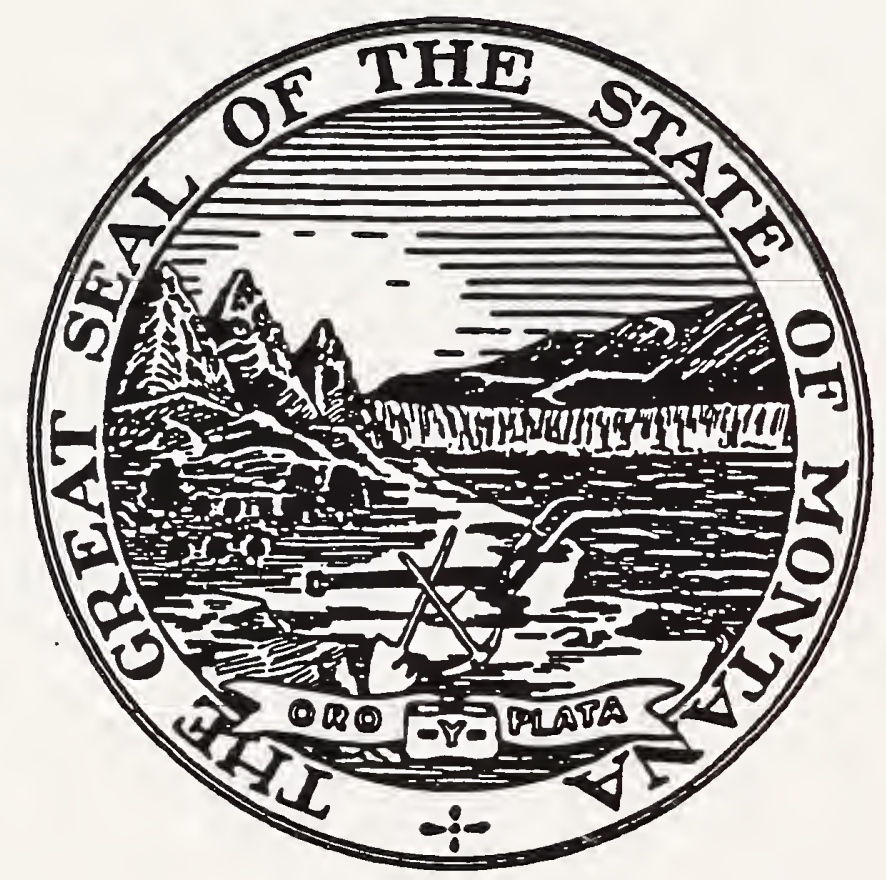

STATE OF MONTANA

DEPARTMENT OF AGRICULTURE

HELENA, MONTANA 
COUNTY NOXIOUS WEED CONTROL ACT

\author{
Title 7, Chapter 22 \\ sections \\ 7-22-2101 through 7-22-2153 \\ M C A
}

Amended 1991

AND RULES

Rules 4.5.201 through 4.5.203

State of Montana

Department of Agriculture

Agricultural and Biological Sciences Division

Capitol station

Helena, MT 59620-0205

(406) 444-2944 
7-22-2101

7-22-2102

7-22-2103

7-22-21-4

7-22-2105

7-22-2106

7-22-2107

7-22-2108

7-22-2109

7-22-2110

7-22-2111

7-22-2112

7-22-2113

7-22-2115

7-22-2116

7-22-2117

7-22-2118

7-22-2121

7-22-2122

7-22-2123

7-22-2124

7-22-2125

7-22-2126

7-22-2127

7-22-2128

$7-22-2130$

7-22-2131

7-22-2141

7-22-2142

$7-22-2143$

7-22-2144

7-22-2145

7-22-2146

7-22-2147

7-22-2148

$7-22-2149$

$7-22-2150$

7-22-2151

7-22-2152

$7-22-2153$
Definitions . . . . . . . . . . . . 1

Weed Management Districts Established . . . 2 District Weed Board -- Appointment and Term - 2 Term of office. . . . . . . . . . . . . 2 Organization of District Weed

Board and Compensation . . . . . . . 2 Renumbered 7-22-2115 by Code Commission . . 3 Renumbered 7-22-2116 by Code Commission . . 3 Renumbered 7-22-2117 by Code Commission . . . 3 Powers and Duties of Board. . . . . . . 3 Administrative Hearing -- Appeals . . . . . 3 (Temporary) Liability Restrictions. . . . . . 4 (Temporary) Information on Herbicide Use. . . 4 and 7-22-2114 Reserved. . . . . . . . . . . . 4 Noxious Weeds and Seeds Declared Nuisance . . 4 Unlawful to Permit Noxious Heeds to

Propagate. . . . . . . . . . . . 4 violations. . . . . . . . . . . . . 4 through 7-22-2120 Reserved. . . . . . . . . . . 5 Weed Management Program. . . . . . . . 5 Repealed. . . . . . . . . . . . . . . 5 Procedure in a Case of Noncompliance. . . . . 5 Destruction of Weeds by Board . . . . . . 6 Repealed. . . . . . . . . . . . . 7 Embargo . . . . . . . . . . . . . 7 Repealed. . . . . . . . . . . . . 7 and 7-22-2129 Reserved. . . . ........ . 7

Weed District Supervisor Training . . . . . 7 through 7-22-2140 Reserved. . . . . . . . . . 7 Noxious Weed Fund Authorized. . . . . . . 7 Sources of Money for Noxious Heed Fund. . . 7 Determination of cost of Weed Control

Program. . . . . . . . . . . . . . 8

Payment of Cost of Weed Control Program . . . 8

Expenditures From Noxious Weed Fund - • - . 8 Financial Assistance to Persons

Responsible for Weed Control . . . . . 8

Repealed. . . . . . . . . . . . . . . 9

Tax Liability for payment of

Weed Control Expenses. . . . . . . . 9

Responsibility for Assessments and Taxes for Weed Control Levied on Leased

State Lands. . . . . . . . . . . . 9

Cooperation With state and

Federal-Aid Programs . . . . . . . . 9

Cooperative Agreements. . . . . . . . . 10

Revegetation of Rights-of-Way

and Disturbed Areas. . . . . . . . . 10

Voluntary Agreements for Control

of Noxious Weeds Along Roads . . . . . 11 
COUNTY NOXIOUS WEED CONTROL RULES

4.5.201 Designation of Noxious Weeds......... 12

4.5.202 Category 1............... 12

4.5.203 Category 2............... 12

4.5.204 Category 3............... 13

Part Cross References . . . . . . . . . . . 14 
7-22-2101. Definitions. As used in this part, unless the context indicates otherwise, the following definitions apply:

2103.

$$
\text { "Commissioners" means the board of county commissioners. }
$$

(3) "Department" means the department of agriculture provided for in 2-15-3001.

(4) "District" means a weed management district organized under 7-22-2102.

(5) "Native plant" means a plant endemic to the state of Montana.

(6) "Native plant community" means an assemblage of native plants occurring in a natural habitat.

(7) (a) "Noxious weeds" or "weeds" means any exotic plant species established or that may be introduced in the state which may render land unfit for agriculture, forestry, livestock, wildife, or other beneficial uses or that may harm native plant communities and that is designated:

(i) as a statewide noxious weed by rule of the department; or

(ii) as a district noxious weed by a board, following public notice of intent and a public hearing.

(b) A weed designated by rule of the department as a statewide noxious weed must be considered noxious in every district of the state.

(8) "Person" means an individual, partnership, corporation, association, or state or local govermment agency or subdivision owning, occupying, or controlling any land, easement, or rightof-way, including any county, state, or federally owned and controlled highway, drainage or irrigation ditch, spoil bank, borrow pit, or right-of-way for a canal or lateral.

(9) "Supervisor" means the person employed by the board to conduct the district noxious weed management program and supervise other district employees.

(10) "Weed management" or "control" means the planning and implementation of a coordinated program for the containment, suppression, and, where possible, eradication of noxious weeds. 
7-22-2102. Heed Management Districts Established. A weed management district shall be formed in every county of this state and shall include all the land within the boundaries of the county, except that a weed management district may include more than one county through agreement of the commissioners of the affected counties.

7-22-2103. District Feed Board -- Appointment and Term. The commissioners shall appoint a district weed board.

(2) The commissioners shall, at a public meeting, pass a resolution establishing the number of members of the district weed board and the terms of the appointments. The board must consist of at least three members and no more than nine members, and the members of the board must be residents of the district. A majority of the board members must, be rural agricultural land owners.

(3) The county extension agent in each county and other interested individuals may be appointed to serve as nonvoting members of that district's weed board.

(4) The board members are public officers.

(5) The board may call upon the county attorney for legal advice and services as it may require.

7-22-2104. Term of office. (1) Except as provided in subsection (2), a member of a district weed board serves a term of 3 years and until the gualification of his successor. The term of office begins January 1 .

(2) When a three-member weed board is established, the initial board members serve terms of 1, 2, and 3 years, respectively, as designated by the commissioners. When a fivemember weed board is established, two of the initial members serve terms of 1 year, two serve terms of 2 years, and one serves a term of 3 years. After expiration of an initial term of office, the successor serves a 3-year term as provided in subsection (1).

7-22-2105. Organization of District Feed Board and Compensation. (1) The board shall organize by choosing a chairman and a secretary. The secretary may or may not be a member of the board.

(2) Salary, per diem, and mileage of such board members shall be set by resolution of the commissioners.

(3) A majority of the board constitutes a quorum for the conduct of business. 
7-22-2106. Renumbered 7-22-2115 by Code Commissioner, 2985. 7-22-2107. Renumbered 7-22-2116 by Code Commissioner, 1985. 7-22-2108. Renumbered 7-22-2117 by Code Commissioner, 1985. 7-22-2109. Powers and Duties of Board. (1) The board may:

(a) employ a supervisor and other employees as necessary and provide for their compensation;

(b) purchase such chemicals, materials, and equipment and pay other operational costs as it determines necessary for implementing an effective weed management program. Such costs must be paid from the noxious weed fund.

(c) determine what chemicals, materials, or equipment may be made available to persons controlling weeds on their own land. The cost for such chemicals, materials, or equipment must be paid by such person and collected as provided in this part.

(d) enter into agreements with the department for the control and eradication of any new exotic plant species not previously established in the state which may render land unfit for agriculture, forestry, livestock, wildlife, or other beneficial use if such plant species spreads or threatens to spread into the state; and

management.

(e) perfors other activities relating to weed

The board shall:

(a) administer the district's noxious weed program;

(b) establish management criteria for noxious weeds on all land within the district;

(c) make all reasonable efforts to develop and implement a noxious weed program covering all land within the district owned or administered by a federal agency.

7-22-2110. Administrative Hearing - Appea1s. (1) A person adversely affected by any notice, action, or order of the board may request an administrative hearing before the board. The board shall hold a hearing within 30 days of the request. Participants may be represented by legal counsel. The board shall make a record of the proceeding and enter its order and findings within 7 days after the hearing.

(2) An order of the board may be appealed to the commissioners within 30 days from the time the order is entered. 
The commissioners shall hear such appeal within 30 days after the notice of appeal and shall render their order and findings within 7 days after such hearing. Participants may be represented by legal counsel.

(3) Within 30 days after the commissioners render their order and findings, the person adversely affected may file a petition in district court requesting that the order and findings of the commissioners be set aside or modified. The court may affirm, modify, or set aside the order complained of, in whole or in part.

7-22-2111. (Temporary) Ilability Restrictions. "A district, as defined in 7-22-2101, is liable for damages caused by 1ts use of herblcides only for an act or omission that constitutes gross negligence. The provisions of 2-9-305 apply to board members, supervisors, and employees of a district.: (Terminates July 1 ,

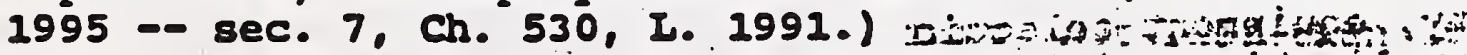

7-22-2112. (Temporary) Information on Berbicide 08e. The district must provide information on protective clothing, health hazards, and proper application techniques to mixers, iloaders, and applicators of herbicides and make information available for review by the public at the district office. (Terminates July 1, $1995-0$ sec. 7, Ch. 530, I. 1991.) b. . $7-22-2113$ and $7-22-2114$ reserved.

7-22-2115. Noxious Feeds and Beeds Declared Hulsance. Noxious weeds and the seed of any noxious weed are hereby declared a common nuisance.

7-22-2116. Unlawful to Permit Noxious reeds to propagate. It is unlawful for any person to permit any noxious weed to propagate or go to seed on his land, except that any person who adheres to the noxious weed management program of his district or who has entered into and is in compliance with a noxious weed management agreement is considered to be in compliance with this section.

7-22-2117. Violations. (1) Any person who in any manner $:$ interferes with the board or its authorized agent in carrying out the provisions of this part or who refuses to obey an order or notice of the board is guilty of a misdemeanor, and upon $\ldots . . . \cdots$ conviction thereof, he shall be fined not. to exceed $\$ 100$ for the first offense and not less than $\$ 100$ or more than $\$ 200$ for each subsequent offense.

(2) All fines, bonds, and penalties collected under the $-2=$ provisions of this part, except those collected by a justice ${ }^{\prime} \mathrm{s}$ court, shall be paid to the county treasurer of each county and placed by him to the credit of a fund to be known as the noxious weed Iund. 
7-22-2118 through 7-22-2120 reserved.

7-22-2121. Weed Management Program. (1) The noxious weed management program must be based on a plan approved by the board.

(2) The noxious weed management plan must:

(a) specify the goals and priorities of the program;

(b) review the distribution and abundance of each noxious weed species known to occur within the district and specify the locations of new infestations and areas particularly susceptible to new infestations;

(c) specify pesticide.management goals and procedures, including but not limited to water quality protection, public and worker safety, equipment selection and maintenance, and pesticide selection, application, mixing, loading, storage, and disposal; and

(d) estimate the personnel, operations, and equipment costs of the proposed program.

(3) The board shall provide for the management of noxious weeds on all land or rights-of-way owned or controlled by a county or municipality within the confines of the district. It shall take particular precautions while managing the noxious weeds to preserve beneficial vegetation and wildlife habitat. Where at all possible, methods for such control shall include cultural, chemical, and biological methods.

(4) The board may establish special management zones within the district. The management criteria in such zones may be more or less stringent than the general management criteria for the district.

7-22-2122. Repealed. Bec. 32, Ch. 607, I. 1985.

7-22-2123. Procedure in a Case of Noncompliance. (1) Where complaint has been made or the board has reason to believe that noxious weeds described in this part are present upon a person's land within the district in violation of the law, that person must be notified by mail or telephone of the complaint and the board may request inspection of such 1and. The board or its authorized agent and the landowner or his representative shall inspect the land at an agreeable time, within 10 days of notification of the landowner. If after reasonable effort the board is unable to gain cooperation of the person, the board or its authorized agent may enter and inspect the land to determine if the complaint is valid. 
If noxious weeds are found, the board or supervisor shall notify the person or his representative and seek voluntary compliance with the district weed control program. If voluntary compliance is not possible, notice of noncompliance must be sent to the person by certified mail.

The notice must specify:

(a) the basis for the determination of noncompliance;

(b) the geographic location of the area of noncompliance, by legal description or other reasonably identifiable description;

(c) measures to be undertaken in order to comply with the district's management criteria;

(d) a reasonable period of time, not less than 10 days, in which compliance measures must be initiated; and

(e) the right of the person to request, within the time specified in subsection (3) (d), an administrative hearing as provided by 7-22-2110.

(4) A person is considered in compliance if he submits and the board accepts a proposal to undertake specified control measures and is in compliance for so long as he performs according to the terms of the proposal. If the measures proposed to be taken extend beyond the current growing season, the proposal and acceptance must be in writing.

(5) In accepting or rejecting a proposal, the board shall consider the economic impact on the person and his neighbors, practical biological and environmental limitations, and alternative control methods to be used.

7-22-2124. Destruction of meeds by Board. (1) If corrective action is not taken and no proposal is made and accepted or no request for an administrative hearing is made within the time specified in the notice, the board may forthwith enter upon the person's land and institute appropriate control measures.

In such case the board shall submit a bill to the person, itemizing man-hours of labor, material, and equipment time, together with a penalty not exceeding 10 \% of the total cost incurred. Labor and equipment must be valued at the current rate paid for commercial management operations in the district. The bill must specify and order a payment due date of 30 days from the date the bill is sent.

A copy of the bill must also be submitted by the board to the county clerk and recorder. 
(3) If a person receiving an order to take corrective action requests an administrative hearing, the board may not institute control measures until the matter is finally. resolved, except in case of an emergency. In such a case, the person is liable for costs as provided in subsection (1) only to the extent determined appropriate by the board, commissioners, or court that finally resolves the matter.

7-22-2125. Repealed. Bec. 32, Ch. 607, I. 1985.

7-22-2126. Embargo. The board may establish voluntary embargo programs to reduce the spread of noxious weeds within the district or the introduction of noxious weeds into the district.

7-22-2127. Repealed. Bec. 32, Ch. 607, I. 1985.

$7-22-2128$ and $7-22-2129$ reserved.

7-22-2130. Weed District supervisor Training. Within the limitations of available funds, the board shall ensure that the weed district supervisor obtains training to properly implement the noxious weed management program described in 7-22-2121. The department shall specify through rulemaking the level and type of training necessary to fulfill this requirement.

7-22-2131 through 7-22-2140 reserved.

7-22-2141. Noxious Feed Fund Authorized. (1) The commissioners of each county in this state, shall create a noxious weed management fund, to be designated the "noxious weed fund".

(2) This fund shall be kept separate and distinct by the county treasurer.

7-22-2142. 8ources of Money For Noxious Feed Fund. (1) The commissioners may create the noxious weed fund and provide sufficient money in the fund for the board to fulfill its duties, as specified in 7-22-2109, by:

county:

(a) appropriating money from the general fund of the

(b) at any time fixed by law for levy and assessment of taxes, levying a tax not exceeding 2 mills on the dollar of total taxable valuation in the county. The tax levied under this subsection must be identified on the assessment as the tax that will be used for noxious weed control; and

(c) levying a tax in excess of 2 mills if authorized by a majority of the qualified electors voting in an election held for this purpose pursuant to 7-6-2531 through 7-6-2536. 
(2) The proceeds of the noxious weed control tax must be used solely for the purpose of managing noxious weeds in the county and must be designated to the noxious weed fund.

(3) Any proceeds from work or chemical sales must revert to the noxious weed fund and must be available for reuse within that fiscal year or any subsequent year.

(4) The commissioners may accept any private, state, or federal gifts, grants, contracts, or other funds to aid in the management of noxious weeds within the district. These funds must be placed in the noxious weed fund.

7-22-2143. Determination of cost of Heed Control Program. Based on the board's recommendations, the commissioners shall determine and fix the cost of the control of noxious weeds in the district, whether the same be performed by the individual landowners or by the board.

7-22-2144. Payment of cost of weed control Program. The total cost of such control shall be paid from the noxious weed fund. The cost of controlling such weeds growing along the right-of-way of a state or federal highway shall, upon the presentation by the board of a verified account of the expenses incurred, be paid from the state highway fund in compliance with 7-14-2132 and any agreement between the board and the department of highways. Costs attributed to other lands within the district shall be assessed to and collected from the responsible person as set forth in 7-22-2116.

7-22-2145. Expenditures From Noxious meed Fund. (1) The noxious weed fund must be expended by the commissioners at the time and in the manner as is recommended by the board to secure the control of noxious weeds.

(2) Warrants upon the fund must be drawn by the board. Warrants may not be drawn except upon claims. duly itemized by the claimant, except payroll claims that must be itemized and certified by the board, and each claim must be presented to the commissioners for approval before the warrant is countersigned by the commissioners.

7-22-2146. Financial Assistance to Persons Responsible For Feed contro1. (1) The commissioners, upon recommendation of the board, may establish cost-share programs with any person, specifying costs that may be paid from the noxious weed fund and costs that must be paid by the person. Cost-share programs may be established for special projects and for established management zones.

(2) (a) When under the terms of any voluntary agreement, whether entered into pursuant to 7-22-2123 or otherwise, or under 
any cost-share program entered pursuant to this section a person incurs any obligation for materials or services provided by the board, the board shall submit a bill to the person, itemizing man-hours of labor, material, and equipment time. The bill must specify and order a payment due date not less than 30 days from the date the bill is sent.

(b) A copy of the bill must be submitted by the board to the county clerk and recorder. If the sum to be repaid by the person billed is not repaid on or before the date due, the county clerk and recorder shall certify the amount thereof, with the description of the land to be charged, and shall enter the sum on the assessment list as a special tax on the land, to be collected in the manner provided in 7-22-2148.

7-22-2147. Repealed. 8ec. 32, Ch. 607, I. 1985.

7-22-2148. Tax Ilability For Payment of Heed Control Expenses. (1) The expenses referred to in 7-22-2124 shall be paid by the county out of the noxious weed fund, and unless the sum to be repaid by the person billed under 7-22-2124 is repaid on or before the date due, the county clerk shall certify the amount thereof, with the description of the land to be charged, and shall enter the same on the assessment list of the county as a special tax on the land. If the land for any reason is exempt from general taxation, the amount of such charge may be recovered by direct claim against the lessee and collected in the same manner as personal taxes. When such charges are collected, they shall be credited to the noxious weed fund.

(2) In determining what lands are included as land covered by the special tax and are described in the certificate of the county clerk, it is presumed that alI work done upon any of the land of any one landowner is for the benefit of all of the land within the district belonging to the owner, together with the parcel upon which the work was done, and the amount certified becomes a tax upon the whole thereof.

7-22-2149. Responsibility For Assessments And Taxes For Feed Control Levied on Leased state Iands. The lessee of agricultural state land is responsible for assessments and taxes levied by the board of county commissioners for the district as provided in 776-114.

7-22-2150. Cooperation Fith 8tate And Pederal-Aid Programs. The board is empowered to cooperate with any state or federal-aid program that becomes available. Under such a plan of cooperation, the direction of the program shali be under the direct supervision of the board of the district in which the program operates. 
7-22-2151. Cooperative Agreements. (1) Any state agency controlling land within a district, including the department of highways; the department of state lands; the department of $\mathrm{fish}$, wildlife, and parks; the department of institutions; the department of natural resources and conservation; and the university system, shall enter into a written agreement with the board. The agreement must specify mutual responsibilities for noxious weed management on state-owned or state-controlled land within the district.

(2). The board and the governing body of each incorporated municipality within the district shall enter into a written agreement and shall cooperatively plan for the management of noxious weeds within the boundaries of the municipality. The board may implement management procedures described in the plan within the boundaries of the municipality for noxious weeds only. Control of nuisance weeds within the municipality remains the responsibility of the governing body of the municipality, as specified in 7-22-4101.

(3) A board may develop and carry out its noxious weed management program in cooperation with boards of other districts, with state and federal governments and their agencies, or with any person within the district. The board may enter into cooperative agreements with any of these parties.

7-22-2152. Revegetation of Rights-or-Fay And Disturbed Areas. (1) Any state agency or local government unit approving a mine, major facility, transmission line, solid waste facility, highway, subdivision, or any other development resulting in significant disturbance of land within a district shall notify the board.

(2) Whenever any person or agency disturbs vegetation on an easement or right-of-way within a district by construction of a road, irrigation or drainage ditch, pipeline, transmission line, or other development, the board shall require that the disturbed areas be seeded, planted, or otherwise managed to reestablish a cover of beneficial plants.

(a) The person or agency disturbing the land shall

submit to the board a written plan specifying the methods to be used to accomplish revegetation. The plan must describe the time and method of seeding, fertilization practices, recommended plant species, use of weed-free seed, and the weed management procedures to be used.

(b) The plan is subject to approval by the board, which may require revisions to bring the revegetation plan into compliance with the district weed management plan. Upon approval by the board, the revegetation plan must be signed by the chairman of the board and the person or agency responsible for the disturbance and constitutes a binding agreement between the 
board and such person or agency.

7-22-2153. Voluntary Agreements For Control of Noxious Feeds Along Roads. (1) Any person may voluntarily seek to enter into an agreement for the management of noxious weeds along a state or county highway or road bordering or running through his land. The supervisor may draft such an agreement upon the request of and in cooperation with the person; however, the agreement must, in the board's judgment, provide for effective weed management. The weed management agreement must be signed by the person and, upon approval of the board, by the chairman. An agreement involving a state highway right-of-way must also be signed by a representative of the department of highways.

(2) The agreement must contain a statement disclaiming any liability of the board and, if applicable, the department of highways for any injuries or losses suffered by the person in managing noxious weeds on the state or county highway right-ofway. The signed agreement transfers responsibility for managing noxious weeds on the specified section of right-of-way from the board to the person signing the agreement. If the board later finds that the person has failed to adhere to the agreement, the board shall issue an order informing the person that the agreement will be void and that responsibility for the management of noxious weeds on the right-of-way will revert to the board unless the person complies with the provisions of the agreement within a specified time period. 


\section{RULES \\ COUNTY NOXIOUS WEED LIST \\ Sub-Chapter 2 \\ Designation of Noxious Weeds}

4.5.201. Designation of Noxious Feeds. (1) The department designates certain exotic plants listed in these rules as statewide noxious weeds under the County Weed Control Act 7-222101 (5), MCA. All counties must implement management standards for these noxious weeds consistent with weed management criteria developed under 7-22-2109 (2) (b) of the Act. The department established three categories of the noxious weeds. (History: Sec. 7-22-2101 MCA; IMP, Sec. 7-22-2101 MCA; NEW 1986, p. 337 , Eff. 3/14/86; AND, 1991 MAR p. 511, Eff. 4/26/91.)

4.5.202. Category 1. (1) Category 1 noxious weeds are weeds that are currently established and generally widespread in many counties of the state. Management criteria includes awareness and education, containment and suppression of existing infestations and prevention of new infestations. These weeds are capable of rapid spread and render land unfit or greatly limit beneficial uses.

(2) The following are designated as category 1 noxious weeds:

(a) Canada Thistle (Cirsium arvense)

(b) Field Bindweed (Convolvulus arvensis)

(c) Whitetop or Hoary Cress (Cardaria draba)

(d) Leafy Spurge (Euphorbia esula)

(e) Russian Knapweed (Centaurea repens)

(f) Spotted Knapweed (Centaurea maculosa)

(g) Diffuse Knapweed (Centaurea diffusa)

(h) Dalmatian Toadflax (Iinaria dalmatica)

(i) st. Johnswort (Hvpericum perforatum).

(History: Sec. 7-22-2101 MCA; IMP, Sec. 7-22-2101 MCA; NEF 1986 MAR P. 337, Eff. 3/14/86; AND, 1991 KAR P. 511, Eff. 4/26/91.)

4.5.203. Category 2. (1) Category 2 noxious weeds have recently been introduced into the state or are rapidly spreading from their current infestation sites. These weeds are capable of rapid spread and invasion of lands, rendering lands unfit for beneficial uses. Management criteria includes awareness and education, monitoring and containment of known infestations and eradication where possible. 
(2) The following are designated as category 2 noxious weeds:

(a) Dyers Woad (Isatis tinctoria)

(b) Purple Loosestrife or Lythrum (Lythrum salicaria, I, virgatum, and any hybrid crosses thereof).

(c) Sulfur (Eract) Cinquefoil (Rotentilla recta)

(History: Sec. 7-22-2101 and 80-7-802 MCA; MP Sec. 7-22-2101 MCA: EW 1986 MAR p. 337, Eff. 3/14/86; AND, 1989 MAR p. 899, Eff. 7/14/89; AND 1991 MAR P. 511, Eff. 4/26/91.)

4.5.204 Category 3. (1) Category 3 noxious weeds have not been detected in the state or may be found only in small, scattered, localized infestations. Management criteria includes awareness and education, early detection and immediate action to eradicate infestations. These weeds are know pests in nearby states and are capable of rapid spread and render land unfit for beneficial uses.

(2) The following are designated as category 3 noxious weeds:

(a) Yellow Starthistle (centaurea solstitialis)

(b) Common Crupina (crupina vulgaris)

(c) Rush Skeletonweed (Chondrilla juncea)

(History: Sec. 80-7-802 MCA; IMP, Sec.7-22-2102 MCA; NEW 1991 MAR P.511, Eff. 4/26/91.) 
Part Cross References:

Weed Control - Department of Agriculture, Title 80, Chapter 7, Part 7.

Municipal Weed Control, 7-22-4101.

Noxious Weed Management Funding, Title 80 , Chapter 7, Part 8. Embargo against introduction of noxious weed seed from other state, 80-7-701.

General authority of county commissioners, 7-5-2101.

county officers - term of office, 7-4-2205.

Nuisance, Title 27, Chapter 30.

Classification of offenses, 45-1-201.

Department of State Lands, general powers and duties, Title 77, Chapter 1, Part 3.

Mining on State Lands, Title 77, Chapter 3.

Department of Fish, wildlife and Parks, general powers and duties, Title 87, Chapter 1, Part 2.

Department of Highways, general powers and duties, Title 60, Chapter 2, Part 7.

Highways, acquisition and disposition of property, Title 60, Chapter 4.

Highway maintenance agreements with local government, 60-2-204. Montana Environmental Protection Act, Title 75, Chapter 1. Montana Solid Waste Management Act, Title 75, Chapter 10, Part 2. County Taxation, Title 7, Chapter 6, Part 25.

Department of Institutions, general powers and duties, Title 53, Chapter 1, Part 2.

University system, Title 20, Chapter 5.

Department of Natural Resources and Conservation established 215-3301.

Major Facility Siting Act, Title 75, Chapter 20:

Subdivisions, Title 76, Chapter 2 and 3.

Coal mining, Title 82 , Chapter 3.

Oil and gas conservation, Title 82, Chapter 11.

Hard rock mining impact, Title 90 , Chapter 6, Part 3.

Role and duties of county clerk, 7-4-2611.

Exployment of personnel by county commissioners. 7-5-2107.

$5.1 \mid$ weed |county1.wp 



\section{APPENDIX B}

\section{SYNOPSIS OF NOXIOUS WEED SPECIES}





\section{State Declared Noxious Weed Species}

CATEGORY 1 noxious weeds are weeds that are currently established in many counties of the state. Management criteria for control of these weeds is necessary in all counties to contain or suppress existing infestations or to prevent, through eradication or other appropriate measures, new infestations of these weeds. All of these weeds render land unfit or greatly limit the beneficial uses (rule 4.5.202).

\section{Canada thistle (Cirsium arvense)}

Canada thistle is a perennial forb that reproduces by horizontal roots and seed. The stems are hollow and branch near the top. The wavy leaves are deeply cut with spiny to smooth margins. The flower heads are numerous, small, compact, and vary from light lavendar to rose-purple. Canada thistle grows in cultivated fields, meadows, pastures, and waste areas.

\section{Dalmatian toadflax (Linaria dalmatica)}

Dalmatian toadflax is a perennial forb that spreads by creeping rootstalk and seed. The plants are pale green and have very showy yellow flowers. The "spurred" flowers are tinged with orange and are about 1 inch long. The leaves are broad, heartshaped, and clasp the stem. Dalmatian toadflax is an escaped ornamental that invades rangeland, and is difficult to control.

\section{Field bindweed (Convolvulus arvensis)}

Field bindweed, a perennial forb, has an extensive, deep root system. Stems are prostrate, 1-4 feet long with numerous arrowhead-shaped stem leaves which form dense tangled mats. The white to pinkish flowers are trumpet-shaped and bloom from late June to frost. The plant propagates by seed and rhizome. Seeds remain viable for up to 50 years making this persistent weed very difficult to control. It is largely a problem in cultivated fields and waste areas.

\section{Leafy spurge (Euphorbia esula)}

Leafy spurge is a perennial forb which reproduces by vigorous rootstalk and seeds. The small flowers are enclosed by a pair of yellowish-green, heart shaped bracts which have the appearance of flowers. Stems, leaves and flowers contain a milky sap called latex, which may cause severe rashes in humans. The weed forms dense patches and may be the most persistent noxious weed in Montana. It has wide habitat suitability, prolific reproductive capabilities, strong competitive ability and is difficult to control, especially along water bodies. Although it is unpalatable to cattle, leafy spurge will be grazed by sheep and goats when they are confined to an infested area. 


\section{Russian knapweed (Centaurea repens)}

Russian knapweed is a perennial forb that spreads by creeping rootstalk and seed. The plant has numerous branches that are tipped with a single, lavender thistle-like flower. The leaves are small and narrow with broken edges. The roots are dark brown and have a scaly appearance. Once, established, it will completely crowd out other vegetation. Livestock tend to avoid the weed because of its bitter, quinine-like taste. Horses, if forced to graze Russian knapweed, will develop nervous disorders.

\section{Spotted knapweed (Centaurea maculosa)}

Spotted knapweed is a short-lived perennial forb that reproduces by seed. The seeds germinate in the spring and fall, whenever growing conditions are favorable. The showy, purple flowers are held in spotted bracts. The alternate leaves have deep, narrow divisions and a rough, hairy appearance. It is very nutrient competitive, accelerating the decline of native vegetation.

\section{Diffuse knapweed (Centaurea diffusa)}

Diffuse knapweed is a biennial or short lived perennial forb. The tip of each branch has a single flower head. The flowers are usually white or sometimes pinkish. Bracts are yellowish green with a light brown margin. The upper part of each bract narrows into a still spine. It is an excellent competitor on dry sites.

\section{St. Johnswort (Hypericum perforatum)}

St. Johnswort is most commonly known as "goatweed". A perennial forb, it reproduces by seed and rootstock. The stems are smooth, branched and woody at the base. The opposite leaves have small glandular dots. Flowers are orange-yellow with 5 petals. Goatweed is found in meadows, dry pastures, rangelands, neglected fields, and along the roadside. Goatweed causes photo-sensitive reactions in livestock and should be regarded as a poisonous plant.

\section{Whitetop (Cardaria draba)}

Whitetop, also known as "hoary cress", is a perennial forb which reproduces by seeds and creeping roots. The dense flowers give the plant a white, flat-topped appearance. The leaves are grayish-green. The upper leaves clasp the stem. 
CATEGORY 2 noxious weeds are weeds that have not been detected in or have recently been introduced into the State of Montana. These weeds have the potential for rapid spread and invasion of lands, thereby rendering them unfit for beneficial uses. County planning to prevent the spread or introduction of these weeds is necessary. Management criteria for detection and immediate action to eradicate or contain these weeds is necessary in all counties (rule 4.5.203).

\section{Dyers woad (Isatis tinctoria)}

Dyers woad is a perennial, biennial or annual forb reproducing by seeds and from roots. The plants have a smooth, bluish-green color. The lower leaves clasp the stem with ear-like projections. The yellow flowers are very small and form a flat-topped inflorescence. The seed pods are winged like a maple seed and turn black when mature. The purplish-black seed pods have been used for their dye extract, thus the name dyers woad.

\section{Purple loosestrife (Lythrum salicaria)}

Purple loosestrife is an aggressive perennial plant that is capable of invading our wetlands and replacing valuable wetland plants. Its dense root mats choke waterways, eliminating food and shelter for wildlife. It grows from underground roots, sprouts from broken off plant parts, and is a prolific seed producer. The flowers have a purple-magenta color. The leaves are linear shaped with smooth edges and are attached directly to a four-sided stem. Purple loosestrife is often confused with Blazing Star, Fireweed, or Blue Vervain.

\section{Sulfur cinquefoil (Potentilla recta)}

Sulfur cinquefoil is also referred to as "upright" or "rough fruited" cinquefoil. It is a perennial forb and reproduces by seed. The stems are hairy and rigid. The leaves are alternate and palmately divided with 5 to 7 coarsely toothed leaflets. The clustered flowers are a sulfur yellow. Sulfur cinquefoil is difficult to distinguish from several other native cinquefoils. 
CATEGORY 3 noxious weeds have not been detected in the state or may be found only in small, scattered localized infestations. Management criteria includes awareness and education, early detection and immediate action to eradicate infestations. These weeds are known pests in nearby states and are capable of rapid spread and render land unfit for beneficial uses.

\section{Common crupina (Crupina vulgaris)}

Common crupina is a annual that reproduces by seed. It is closely related to the knapweed species. The leaves are large, thick, and dark green with stiff hairs that feel sticky. The plant produces 5 to 100 flower heads with a lavender to purple color, which from a distance could be confused with spotted knapweed. It is generally found on well-drained, rocky to silt loam soils in pastures or rangeland. Cattle will not feed on common crupina plants. The species is competitive and forms solid stands reducing forage production and range carrying capacity. Infestations start in disturbed sites with sparse vegetation. Common crupina is not believed to be in Montana at this time.

\section{Rush skeletonweed (Chondrilla juncea)}

Rush skeletonweed, a member of the sunflower family, is a perennial $1-4$ feet tall with a deep, extensive root system. It branches off of several main stems which have downward bent, coarse hairs on the lower 4-6 inches. Leaves occur at the base and resemble those of dandelions. Yellow flowering heads are small and scattered on branches. Flowering and seed production occurs from late summer through frost. This species generally inhabits well-drained, light-textures soils along roadsides, in rangelands, grain fields and pastures. Rush skeletonweed occupies large acreage in Oregon, Washington, Idaho and California. This species should not be confused with the rangeland native, skeletonweed, (Lygodesmia juncea) which has pink flowers.

\section{Yellow star-thistle (Centaurea solstitialis)}

Yellow star-thistle is an annual or, occasionally, biennial that reproduces by seed. The leaves are alternate and have slender, pointed lobes. The upper leaves are smaller and narrow with sharp, spiny tips. Leaf bases extend down the plant stem giving a winged effect. The flowers heads have sharp stiff spines on either side with one flower per branch. The flowers are yellow, long and tubular. It is toxic to horses and when eaten in quantity, results in a neurological disorder which over time causes death. The chewing disease associated with it comes from the spikes on the flower. 


\section{Other Watch Species}

Eurasian watermilfoil (Myriophyllum spicatum)

Eurasian watermilfoil is an aggressive aquatic weed which is flourishing in Washington and Idaho. It resembles native milfoils with its lacy leaves and reproduces by seed and vegetative propagation. Water-milfoil roots in shallow streams and lakes in up to 15 feet of water forming extremely dense mats. It chokes waterways and irrigation ditches and depletes oxygen and therefore is a serious problem for recreationists, fisheries and landowners. The species appears to have a wide tolerance to severe environmental conditions and can resprout from seemingly dried out stems and roots. Thus it is easily spread by boats and trailers that carry fragments from infested waters to clean waters. 


\section{County Declared Noxious Weed Species}

In addition to the state-declared noxious weed species specified in the County Noxious Weed Control Act, individual counties may also declare additional species as noxious and mandate control actions through their County Noxious Weed Control Management Plans. The following list summarizes these additional species for the counties within the administrative boundaries of DFWP Region 7.

Weed Species

Scientific Name

County (-ies)

Black henbane

Hysocamus niger

Big Horn

Common burdock

Articum minus

Big Horn

Common tansy

Tanacetum vulgare

Rosebud

Hounds tongue

Cynoglossum offinale

Dawson

Musk thistle

Cardus nutans

Rosebud

Orange hawkweed

Hieracium aurantiacum

Dawson

Periennial sowthistle

Sonchus arvensis

Prairie

Poisonhemlock

Conium maculatum

Big Horn, Prairie, Rosebud

Salt cedar

Tamarix ramoissima

Prairie

Scotch thistle

Onopordum acanthium

Rosebud

Yellow toadflax

Linaria vulgaris

Prairie 


\section{APPENDIX C}

LAWS AND POLICIES RELATING TO THE MANAGEMENT OF

NOXIOUS WEEDS 


\section{Laws and Policies Relating to the Management of Noxious Weeds}

State and federal laws, policies, and programs that affect DFWP Region 7's activities include:

- Creating a VISION for the Future of Montana's Department of Fish, Wildlife \& Parks (1992)

- Weed Control Program for Lands Managed by the Montana Department of Fish, Wildlife and Parks (1983)

- Montana Pesticides Act (80-8-801 et seq., MCA)

- Montana Weed Control Act (80-7-701 et seq., MCA)

- Montana Noxious Weed Trust Fund Act of 1985 (80-7-801 et seq., MCA) as amended 1991 and Rules

- 95 MT Legislature's House Bill \#395 (MCA 7-22-2151)

- Montana Water Quality Act (75-5-101 et seq., MCA)

- Montana Agricultural Chemical Ground Water Protection Act of 1989 (80-15-100 et seq., MCA)

- Montana Environmental Policy Act (MEPA, 75-1-101 et seq., MCA)

- County Weed Boards for Big Horn, Carter, Custer, Dawson, Fallon, Garfield, Prairie, Richland, Rosebud and Treasure counties; 5-Year Plans

- Montana Department of Agriculture Chemical Use Reporting Procedures

- Federal Insecticide, Fungicide, and Rodenticide Act (FIFRA) P.L. 92-516; CFR 40-171

- USDI Bureau of Land Management - Miles City District

- US Environmental Protection Agency

- US Department of the Army, Corps of Engineers - Omaha District 



\section{APPENDIX D}

BIOLOGICAL CONTROL AGENTS AVAILABLE IN MONTANA 

Host

Knapweeds

Leafy spurge

St. johnswort

Musk thistle

Canada thistle

Canada thistle

Dalmatian toadflax
Control Agent

Agapeta zoegana

Chaetorellia acrolophi

Cyphocleonus achates

Larinus minutus

Larinus obtusus

Metzneria paucipunctella

Pelochrista medullana

Pterolonche inspersa

Sclerotinia spp.

Sphenoptera jugoslavica

Subanguinia picridis

Terellia virens

Urophora affinis

Urophora quadrifasciata

Aphthona nigriscutis

Aphthona cyparissiae

Aphthona flava

Aphthona czwalinae

Bayeria spp.

Hyles euphorbiae

Oberea erythcrocephala

Spurgia esulae

Chrysolina quadrigemini

Rhinocyllus conicus

Trichosiracalus horridus

Ceutorhynchus litura

Urophora cardui

Larinus planus

Calophasia lunula
Action

root mining moth

seed head fly

root weevil

seed head weevil

seed head beetle

flowerette and seed moth

root mining moth

root moth

fungus

root mining beetle

leaf gall nematode

seed head fly

seed head gallfly larvae

seed head fly

root and leaf flea beetle root and leaf flea beetle root and leaf flea beetle root and leaf flea beetle shoot tip gall midge defoliating hawk moth larvae stem and root beetle larvae/adults shoot tip gall midge

defoliating beetle

seed head weevil

rosette weevil

stem mining weevil stem and shoot gallfly seedhead weevil

defoliating larvae/moth 


\section{Biological Control Agents Released on Department of Fish, Wildlife and Parks \\ Properties in Region 7}

Host

Control Agent

Release Site

Leafy spurge Aphthona nigriscutis

Pirogue Island S.P.

Aphthona nigriscutis

Makoshika S.P

Aphthona flava

Intake FAS

D-2 
APPENDIX E

HERBICIDE EMERGENCY RESPONSE PLAN 



\title{
Herbicide Emergency Response Plan
}

The improper use or accidental release of an herbicide may pose serious health or environmental hazards. Accidental spills and releases must be managed quickly and efficiently to protect human health and the environment. Additional information on the handling and use of herbicides can be found in the Montana Pesticide Act (80.8.101 MCA) and its Administrative Rules (ARM 4.10.101).

During herbicide emergencies, the first priority is the safety of personnel involved in the accident. The next priority is spill containment and clean-up to minimize environmental contamination. This plan outlines field response and reporting procedures to follow in the event of an herbicide spill. This plan applies to all DFWP personnel and contractors when an accident occurs involving the transport, application, use or handling of an herbicide.

\section{IN THE EVENT OF A SPILL:}

\author{
1. Administer First Aid to Injured or Contaminated Persons \\ 2. Identify Type of Pesticide Released \\ 3. Notify the Appropriate Authorities \\ 4. Quarantine the Area \\ 5. Contain the Spill if Possible \\ 6. Complete Pesticide Emergency Response Record \\ 7. Develop a Clean-Up Plan Where Appropriate
}

\section{Administer First Aid to Injured Persons}

Of greatest importance is the immediate threat to human health and the aid of someone injured during an herbicide spill. Any injured parties should be removed from the contaminated area immediately. Contaminated clothing should be removed. All persons should avoid direct contact with the spilled material until it is positively identified.

If the released chemical is known, labels and Material Safety Data Sheets can be consulted for the appropriate procedures for decontamination and administering first aid. For most herbicides, washing with water and detergent is the best method. Initial first aid for eye contact usually includes rinsing with eye-safe solutions (e.g. contact lens saline solution) or water. Injured parties, should be transported to medical facilities as soon as possible, with the name of the released material, label, and material safety data sheet accompanying the injured person. 


\section{Identify Spilled Material}

To administer the most appropriate emergency response, the spilled herbicide must be accurately identified. Herbicide label information and Material Safety Data Sheets (MSDS) should accompany all DFWP personnel and their contractors if an herbicide is handled, transported, or applied. In addition, MSDS's should also be kept on file at any location where herbicides are stored. MSDS's describe appropriate response procedures for administering emergency aid to affected parties and appropriate protective clothing for containing a spill. The transporter and applicator of the herbicide must carry records describing mixtures of all herbicides applied.

\section{Notify the Authorities}

Herbicides can pose serious threats to human health and the environment and should be handled with extreme care. All accidental herbicide releases must be reported to the Montana Department of Agriculture within 48 hours. The written report must include the time of the incident, its location, herbicide name, type of formulation, method of application, and the DFWP contact for the project. The report should also name all parties involved in the incident, including the names and addresses of individuals who may be affected by the spill. If the spilled herbicide is classified as either extremely toxic or highly toxic, the Department of Agriculture must be notified immediately. The following authorities may be contacted:

DFWP: Regional Parks Maintenence Supervisor

Local Emergency Response:

County Sheriff's Office:
$232-4365$

911

Big Horn 665-1503

Carter 775-8743

Custer 232-3411

Dawson 365-5291

Fallon 778-2879

Garfield $\quad 557-2540$

Prairie 637-5738

Richland 482-2919

Rosebud 356-2715

Treasure 342-5211

Montana Disaster \& Emergency Services:

(406) $444-6911$

National Response Center:

(800) $424-8802$

Montana Department of Agriculture:

(406) 444-3144

Montana Poison Control Center:

(800) $525-5042$ 
Chemtrec:

(800) $424-9300$

The Chemical Manufacturer's Association maintains this 24 hour hotline to provide information about chemicals and their related health and environmental hazards for fire and police crews responding to chemical accidents and spills.

\section{Quarantine the Area}

In the event of a spill, restrict access to the site, using physical barriers such as emergency tape, flagging, or signs. The area should be secured to prevent entry of unauthorized personnel into the spill area. Only authorized persons wearing the appropriate protective clothing should be permitted into the area.

\section{Contain the Spill}

Once the spilled material is positively identified, it must be contained as soon as possible. Technical labels and MSDS's provide information on protective clothing requirements for cleanup personnel. Generally, it will be clothing similar to the protective clothing required for application.

Put on all necessary protective clothing, including respirators, before approaching the spill from an upwind direction. Avoid inhaling fumes, vapors, and dust from the spill. Smoking is not allowed in a spill area. Examine the area and determine an effective method to contain the spill. Any person attempting to contain a spilled herbicide should also follow these guidelines:

- $\quad$ minimize human contact with the spill, using mechanized equipment if possible

- $\quad$ avoid raising dust

- $\quad$ avoid diluting material with water (except for misting dry substances)

- treat all absorbent material used during containment as a hazardous waste

- remove and dispose of all contaminated soil as a hazardous waste

- wash and properly decontaminate hands and face prior to consuming any food 
Potential spill containment methods include:

\section{Liquid Spills}

- create small collection pools for runoff

- create dikes to impound runoff

- cover spill material with approximately double its volume in absorbent material (hydrated lime, saw dust, kitty litter)

- $\quad$ transfer absorbent material onto an impermeable barrier (e.g. tarp)

- divert spilled material away from open waters

- monitor and plug leaks in containment structures

\section{$\underline{\text { Dry Spills }}$}

- cover with a plastic tarp and secure edges of the tarp

- $\quad$ spray fine mist to minimize dust

- $\quad$ shovel material into clearly marked plastic bags or drums and seal

\section{Record Herbicide Spill}

An herbicide spill or accident can have long lasting effects beyond immediate health and environmental threats. It is important to document all circumstances and events pertaining to the accident and/or spill. Important information includes the name and type of herbicide (include MSDS sheets), the names of any injured or contaminated persons, amount spilled or released, spill location, and whether chemicals were discharged into a water body. Below is a form to record all appropriate information. 


\section{HERBICIDE SPILL EMERGENCY RESPONSE FORM}

Complete all appropriate items and add additional notes to document special conditions or unusual circumstances. Take photos when possible to supplement notes.

1. Immediately contact the appropriate response agencies.

2. Were there injuries related to the spill?

Were any individuals contaminated with herbicide?

Was aid provided to affected individuals?

Was transportation to a medical facility required?

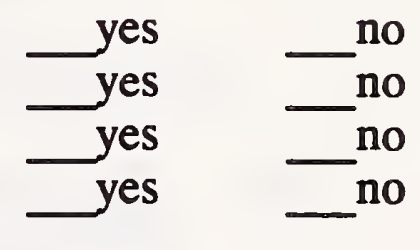

3. Was a vehicle accident involved?

4. What materials/herbicides were involved? (include MSDS)

5. Estimate amount of herbicide or herbicide mixture spilled in gallons.

Herbicide:

Herbicide:

Herbicide: gals Mixture: gals gals gals

Mixture: gals

Mixture: gals

6. Location of Incident (name of site):

$1 / 4 \_1 / 4 \_$Sec ${ }^{T} \mathrm{~T} \longrightarrow \mathrm{R}$ Highway/Road:

Time of Incident: - — - Date:

Provide a description of the site (water bodies, vegetation, landmarks)

Distance to picnic/play campground area:

nearest well:

surface water:

7. Is there a danger of surface water contamination?

Has an herbicide already entered the water body?

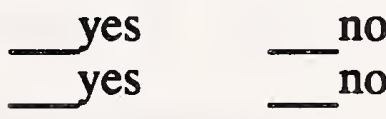

Name of Stream/Lake

8. Is there a danger of ground water contamination?

Depth to groundwater:

Elevation above nearest surface water: 


\section{HERBICIDE SPILL EMERGENCY RESPONSE FORM, page 2}

9. General Soil Description (check one for surface and subsurface soil)

Surface $\quad \square$ Dark Colored, Organic, Rock Free

口 Medium Textured

ㄴ Light Colored, Rocky

Subsoil $\quad \square$ Dark Colored, Organic, Rock Free

口 Medium Textured

ㄴ Light Colored, Rocky

10. List Agencies Notified

FWP Authority

Local Authority

State Authority

Federal Authority

Other Authority

When

When

When

When

When

11. Site Sketch

12. Describe Incident:

13. Public Contact/Comment During Incident:

14. Name:

Date: 


\section{CHEMICAL EMERGENCY SPILL KIT}

All FWP personnel and contractors applying or transporting herbicides must carry the following safety items in the vehicle.

- at least one pair of neoprene or plastic gloves for each crew member present

- at least one pair of rubber, neoprene, or plastic material boots

- at least one pair of unvented goggles for each crew member present

- at least one approved respirator for applied pesticide

- at least one pair of coveralls or disposable coveralls (Tyvek) for each crew member

- absorbent material (kitty litter, floor dry)

- heavy duty plastic garbage sacks

- $\quad$ plastic tarp

- shovel

- dustpan and shop brush

- one pint liquid detergent

- portable eye wash kit

- five-pound $\mathrm{ABC}$-type fire extinguisher

- $\quad$ first aid kit

- safety tape/flagging

- material safety data sheets and technical label information for each herbicide handled and used

- herbicide spill response plan 



\section{APPENDIX F}

\section{SENSITIVE SPECIES OCCURRING IN THE VICINITY OF MONTANA DEPARTMENT OF FISH, WILDLIFE AND PARKS PROPERTIES IN}

REGION 7 



\section{Sensitive Species Occurring in the \\ Vicinity of Department of Fish,}

\section{Wildlife and Parks Region 7 Properties ${ }^{1}$}

Site Name

Elk Island WMA ${ }^{2}$

Fort Keogh WMA

Isaac Homestead WMA

Amelia Island FAS ${ }^{4}$

Bonfield FAS

Bonfield FAS

East \& West Rosebud FAS's

East \& West Rosebud FAS's

Fallon Bridge FAS

Far West FAS

Gartside FAS

Gartside FAS

Gartside FAS
Species Occurrence and Status

Meadow Jumping Mouse (Zapus hudsonius); rare and local throughout its range.

Schweinitzi' Flatsedge (Cyperus schweinitzii); imperiled in Montana because of its rarity; vunerable to extinction.

Great Blue Heron rookery; nesting site and territory, sensitive species.

Bald Eagle (Haliaeetus leucocephalus): nesting site and territory; listed as endangered under the Endangered Species Act.

Great Blue Heron rookery; nesting site and territory, sensitive species.

Interior Least Tern (Sterna Antillarum athalassos); nesting site; critically imperiled in Montana because of extreme rarity; vulnerable to extinction.

Bald Eagle (Haliaeetus leucocephalus): nesting site and territory; listed as endangered under the Endangered Species Act.

Paddlefish (Polyodon spathula); imperiled because of rarity.

Interior Least Tern (Sterna Antillanum athalassos); nesting site; critically imperiled in Montana because of extreme rarity; vulnerable to extinction.

Bald Eagle (Haliaeetus leucocephalus): nesting site and territory; listed as endangered under the Endangered Species Act.

Meadow Jumping Mouse (Zapus hudsonius); rare and local throughout its range.

Great Blue Heron rookery; nesting site and territory, sensitive species.

Prairie Aster (Aster ptarmicoides); critically imperiled in Montana because of its rarity; vulnerable to extinction. 


\section{Sensitive Species Occurring in the \\ Vicinity of Department of Fish,}

\section{Wildlife and Parks Region 7 Properties \\ (cont.) ${ }^{1}$}

\section{Site Name}

Intake FAS

Intake FAS

Makoshika State Park ${ }^{3}$

Makoshika State Park

Medicine Rocks State Park

Medicine Rocks State Park

Medicine Rocks State Park

Medicine Rocks State Park

Medicine Rocks State Park

Medicine Rocks State Park

Medicine Rocks State Park

Medicine Rocks State Park

\section{Species Occurrence and Status}

Pallid Sturgeon (Scaphirhynchus albus); listed as endangered.

Sturgeon Chub (Hybopsis gelida); imperiled in Montana because of rarity, vulnerable to extinction.

Rocky Mountain Juniper - Little-Seed Ricegrass (Juniperus scopulorum - Oryzopsis micrantha); habitat type, rare and local throughout its range.

Blue Toadflax (Limaria canadensis var. texana); imperiled in Montana because of rarity, vulnerable to extinction.

Narrow-leaved Milkweed (Asclepias stenophylla); imperiled in Montana because of rarity, vulnerable to extinction.

Smooth Goosefoot (Chenopodium subglabrum); imperiled in Montana because of rarity, vulnerable to extinction.

Silky Prairie Clover (Dalea villosa var. villosa); imperiled in Montana because of rarity, vulnerable to extinction.

Narrowleaf Pentstemon (Pentstemon augustifolius); imperiled in Montana because of rarity, vulnerable to extinction.

Schweinitz' Flatsedge (Cyperus schweinitzii); imperiled in Montana because of rarity, vulnerable to extinction.

Moss Phlox (Phlox andicola); imperiled in Montana because of rarity, vulnerable to extinction.

Sand Bluestem/Needle-and-Thread (Andropogon hallii - Stipa comata); community type; restricted range or distribution.

Silver Sagebrush - Long Stolon Sedge (Antemisia cana - Carex heliophila); community type; restricted range or distribution. 


\section{Sensitive Species Occurring in the \\ Vicinity of Department of Fish,}

\section{Wildlife and Parks Region 7 Properties \\ (cont.) $)^{1}$}

\section{Site Name}

Myer's Bridge FAS

Pirogue Island State Park

Pirogue Island State Park

Powder River FAS

Powder River FAS

Powder River FAS

Roche Juane FAS

Roche Juane FAS

Sidney Bridge FAS

Sidney Bridge FAS

\section{Species Occurrence and Status}

Bald Eagle (Haliaeetus leucocephalus): nesting site and territory; listed as endangered under the Endangered Species Act.

Pallid Sturgeon (Scaphirhynchus albus); listed as endangered.

Paddlefish (Polyodon spathula); imperiled because of rarity.

Pallid Sturgeon (Scaphirhynchus albus); listed as endangered.

Paddlefish (Polyodon spathula); imperiled because of rarity.

Sturgeon Chub (Hybopsis gelida); imperiled because of rarity, vulnerable to extinction.

Pallid Sturgeon (Scaphirhynchus albus); listed as endangered.

Paddlefish (Polyodon spathula); imperiled because of rarity.

Meadow Jumping Mouse (Zapus hudsonius); rare and local throughout its range.

Townsend's Big-Eared Bat (Plecotus townsendii); imperiled because of rarity.

1 Information provided by the Montana Natural Heritage Program, February 1995.

2 Wildlife Management Area.

3 State Park.

4 Fishing Access Site. 


\section{APPENDIX G}

\section{HERBICIDES PROPOSED FOR USE ON DEPARTMENT OF FISH, WILDLIFE AND PARKS REGION 7 PROPERTIES}





\section{Herbicides Proposed for Use on Department of Fish, Wildlife and Parks Region 7 Properties}

The following herbicides have been applied on properties within DFWP Region 7. Individual chemicals have different properties and thus different circumstances for their proper application. This list also represents chemicals from which DFWP will select in the future, so as to use the appropriate herbicide in any given setting. All chemical applications are subject to the guidelines presented in this Plan. Herbicide label instructions will follow in APPENDIX $\mathrm{H}$.

Tordon

Roundup/Ruler

Stinger

Transline

Curtail

Weedar 64, various

Hi-Dep, various piclorum

glyphosate

clopyralid

clopyralid

clopyralid + 2,4-D

2,4-D Amine

2,4-D Ester 


\section{APPENDIX H}

HERBICIDE LABEL INSTRUCTIONS AND SAFETY PRECAUTIONS 

Restricted Use Pesticide

May Injure (Phytotoxic) Susceptible, Non-Target Plants. For retail sale to and use only by Certified Applicators or person under their direct supervision and only for those uses covered by the Cenified Applicator's certification. Commercial cenified applicators must also ensure that all persons involved in these activities are informed of the precautionary statements.

\section{DowElanco}

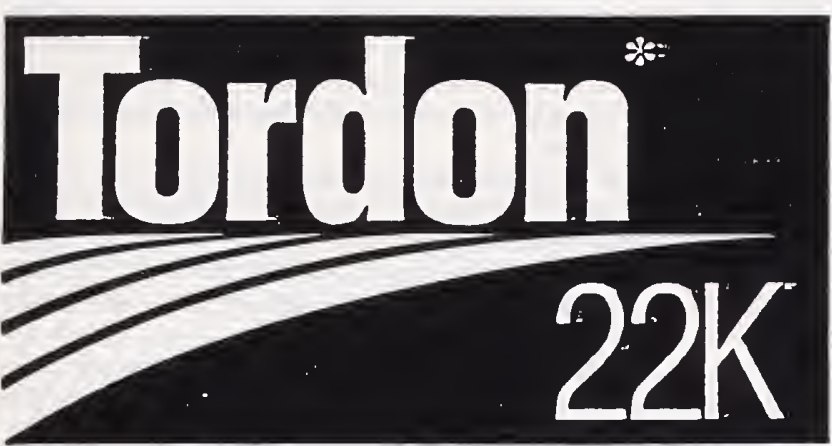

Herbicide:

For use in areas west of the Mississippi River for the control of susceptible broadleaf weeds and woody plants on rangeland and permanent grass pas. tures, fallow cropland, wheat, barley and oats not underseeded with a legume on grainland (which is not flood or sub. irrigated and not rotated to broadleaf crops), non-cropland, and on Conservation Reserve Program (CRP) acres and wildlife openings in forest and non-crop areas

Active Ingredient:

picloram: 4-amino-3,5,6-trichloropicolinic acid, potassium salt . $24.4 \%$

Inert Ingredients. $75.6 \%$

Acid Equivalent

picloram: 4-amino-3,5,6-irichloropicolinic acid . $21.1 \%-2 \mathrm{lb}$ per gal

EPA Reg. No. 62719-6

EPA Est. 464-MI-1

Net Contents $2.5 \mathrm{gal}$

\section{Precautionary Statements}

Hazards to Humans and Domestic

AnImais

\section{Keep Out Of Reach Of Children}

\section{WARNING AVISO:}

- Precaucion al usuario: Si usted no lee inglés, no use este producto hasta que la etiqueta le haya sido explicada ampliamente.

Causes Substantial But Temporary Eye Injury. Harmful If inhaled Or Absorbed Through Skln
Do not get in eyes or on clothing. Wear goggles, face shield or safety glasses when handling. Avoid contact with skln. Wash thoroughiy with soap and water after handling. Remove contam. Inated clothlng and wash before reuse. Avoid breathing spray mist.

\section{First Aid}

If In eyes: Flush with plenty of water for at least 15 minutes. Get medical attention.

\section{Environmental Hazards}

Do not apply directly to water or wetlands (swamps, bogs, marshes, and potholes). Do not contaminate water when disposing of equipment washwaters. Do not contaminate water used for irrigation or domestic purposes by cleaning of equipment or disposal of wastes. Do not allow run-off or spray to contaminate wells, irrigation ditches or any body of water used for irrigation or domestic purposes. Do not make application when circumstances favor movement from treatment site.

Picloram is a chemical which can iravel (seep or leach) through soil and under certain conditions has the potential to contaminate groundwater which may be used for irrigation and drinking purposes. Users are advised not to apply picloram where soils have a rapid to very rapid permeability throughout the pro. file (such as loamy sand to sand) and the water table of an underlying aquifer is shallow or to soils containing sinkholes over limestone bedrock, severely fractured surfaces, and substrates which would allow direct introduction into an aquifer. Your local agricultural agencies can provide further information on the type of soil in your area and the location of groundwater.

An aquifer is defined as "an underground, saturated, permeable, geologic formation capable of producing significant quantities of water to a well or spring. It is the ability of the saturated zone, or portion of that zone, to yield water which makes it an aquifer" (American Chemical Society, 1963).

Note: Use in Hawail limited exciusively to Suppiemental Labeling. See "Generai Use Precautions" for details.

Notice: Read the entire iabel. Use only according to label directions. Before buying or using this product, read "Warranty Disclaimer" and "Limitation of Remedies"sections eisewhere on this iabel.

In case of emergency endangering health or the environment involving this product, call collect 517. 636-4400.

Agricultural Chemical: Do not ship or store with food, feeds, drugs or clothing.

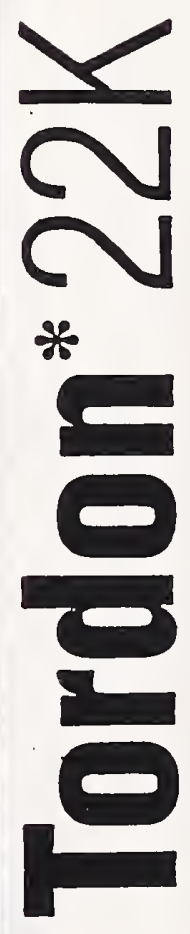




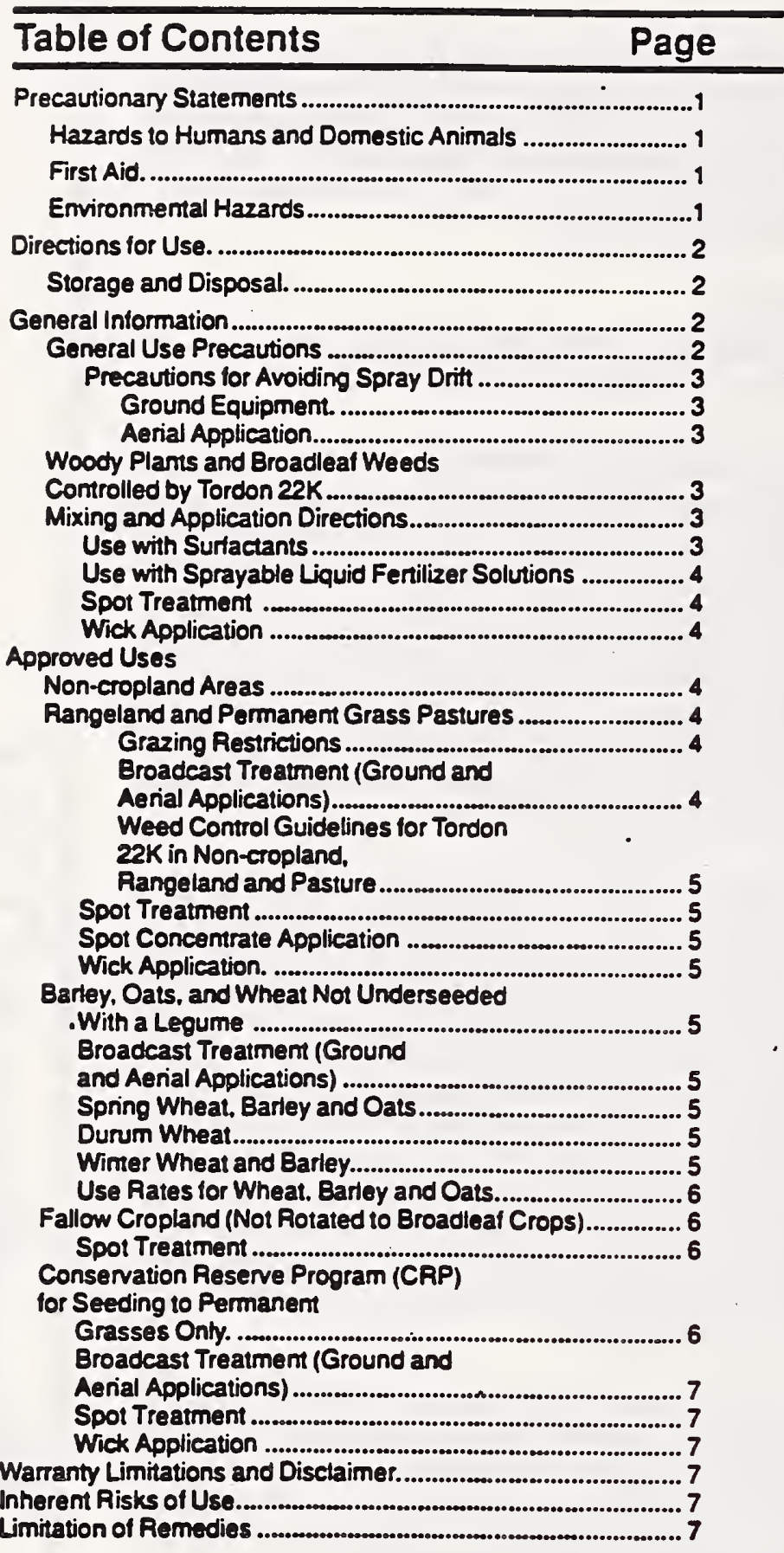

\section{Directions for Use}

It is a violation of Federal law to use this product in a manner inconsis. tent with its labeling.

Read all Directions for Use carefully before applying.

\section{STORAGE AND DISPOSAL}

Do not contaminate water, food, feed or fertilizer by storage or disposal. Open dumping is prohibited.

Pesticlde Dispossl: Wastes resulting from the use of this product may be disposed of on site or at an approved waste disposal facility. Metal Contsiner Dispossl: Do not reuse contsiner. Triple rinse (or equivalent). Puncture and dispose of in a sanitary landfill, or by other procedures approved by state and local authorities.

Pisstic Contalner Disposal: Do not reuse container. Triple rinse (or equivalent). Puncture and dispose of in a sanitary landfill, or by incineration, or, if allowed by state and local authorities, by burning. If bumed, stay out of smoke.

Sprsyer Clean-Out: To avoid Injury to desirable plants, equipment used to apply Tordon $22 \mathrm{~K}$ should be thoroughly cleaned before reusing to apply amy other chemicals.

1. Rinse and flush appllcation equipment thoroughly after use. Dispose of rinse water in non-cropland area away from water supplies.

2. Pinse a second time, adding 1 quant of household ammonia for every 25 gallons of water. Circulate the solution through the entire system so that all internal surfaces are contacted (15 to $20 \mathrm{~min}$ wtes). Let the solution stand for several hours, preferably ovemight.

3. Fiush the solution out the spray tank through the boom.

4. Rinse the system wice with clean water, recirculating and draining each time.

5. Nozzles and screens should be removed and cleaned separately. Ganersi: Consult federal, state or local disposal authorities for approved allemative procedures.

\section{GENERAL INFORMATION.}

In areas west of the Mississippi River use Tordon $22 \mathrm{~K}$ herbicide to control susceptible broadleaf weeds and woody plants on rangeland and permanent grass pastures, fallow cropland, wheat, barley and oats not underseeded with a legume on grainland (which is not flood or sub-irrigated and not rotated to broadleaf crops), non-cropland, and on Conservation Reserve Program (CRP) actes, and wildlife openings in forest and non-crop areas. This product la NOT for asle or use in the San Luis Valley of Colorado.

\section{General Use Precautions}

Use thls product only aa spaclifed on thla label. Observe any special use and application restrictions and limitations, inctuding method of application and permissible areas of use as promulgated by state or boal authorities.

To pravent damaga to cropa and other deslrable plents, read ano follow all directions and precautions on this label and container before using.

Do not use for manutacturing or formulating.

Do Not Mix Whth Dry Fertliker.

Chemigatlon: Do not apply this product through any type of Irrigation system.

In Hawall, approved uses of Tordon 22K are limited to those described in Supplemental Labeling. Thls Supplemental Labeling may be obtained from your DowElanco representative or chemical dealer. Refer to this Supplememal Labeling for specific use directions and precautions.

Do not mske applicatlon when eireumatsncas favor movemant from trestment site. 
Do not apply or otherwise permit Tordon $22 \mathrm{~K}$ or sprays contalning Tordon 22K to contact crops or other desirable broadleaf plants, including but not limited to alfalfa, beans, grapes, melons. peas. potatoes. sattlower, soybeans, sugar beets, suntlower, tomatoes. and other vegetable crops. flowers, truit plants, ornamentals or shade trees or the soil containing roots of nearoy valuable plants.

Precautions for Avoiding Injurious Spray Drift Applications should be made to avoid spray dritt since very small quantities of spray, which may not be visible. may seriously injure susceptible crops during both growing and dormant periods. To minimıze spray dritt. use low nozzle pressure: apply as a coarse spray: and use nozzles designed for herbicide application that do not produce a fine droplet spray. To aid in turther reducing spray drith, a dritt control and deposition aid such as Nalco-Trol may be used with this product. If such a drit control aid is used. tollow all use recommendations and precautions on the product label.

Ground Equipment: With ground equipment spray dritt can be lessened by keeping the spray boom as low as possible: by applying 20 gallons or more of spray per acre: by keeping the operating spray pressures at the manufacturers recommended minimum pressures for the specific nozzle type used (low pressure nozzles are available from spray equipment manulacturers); by spraying when the wind velocity is low (follow state regulations). Avoid calm conditions which may be conducive to air inversions. In hand-gun applications, select the minimum spray pressure that will provide adequate plant coverage (without forming a mist).

Aerial Application: With aerial applications, dritt may be lessened by using a coarse spray; by using a drit control system; or by using NalcoTrol dritt control additive or equivalent. Adjust spray pressure to provide coarse spray droplets and by using nozzles which do not create fine droplets. Spray boom should be no longer than 34 of the wingspan or rotor length. Do not use a thickening agent with the Microfoil or the Thru-Valve booms, or other systems that cannot accommodate thick sprays. Spray only when the wind velocity is low (follow state regulations). Avoid calm conditions which may be con. ducive to air inversions.

Determine Alr Movement and Direetion Betore Foliar Application. Do not spray when wind is blowing toward susceptible crops or orna. mental plants near enough to be injured. It is suggested that a continuous smoke column at or near the spray site or a smoke generator on the spray equipment be used to detect air movements. lapse condiions, or temperature inversions (stable air). If the smoke layers or indjcates a potential of hazardous spray dritt, do not spray.

Do not contaminate water intended for irrigation of domestic pup. poses. To avoid injury to crops or otter desirable plants, do not treat or allow spray drift or run-oft to fall onto banks or bottoms of irrigation ditches. either dry or containing water, or other channels that carry water that may be used for irrigation or domestic purposes.

Do not use on flood or sub-irrigated land.

Do not sprsy if the loss of forage legumes cannot be toleiated. Tordon $22 \mathrm{~K}$ may injure or kill legumes. New legume seedlings may not grow for several years following application of this herbicide.

Do not use manure from animals grazing treated areas on land used tor growing broadleat crops, ornamentals, orchards or other susceptible, desirable plants. Manure may contain enough picloram to cause injury to susceptible plants.

Do not use grass or hsy from treated areas for composting or mulching of susceptible broadleat crops.

Do nol transfer livestock from treated grazing areas onto sensitive broadieat crop areas without first allowing 7 days of grazing on an untreated grass pasture. Othenwise, urine may contain enough picioram to cause injury to sensitive broadleaf plants.

Do not appiy to snow or frozen ground. Application during very cold (near treezing) weather is not advisable.

Tordon 22K should not be applied on residentlal or commercial lawns or near ornamental trees and shrubs. Untreated trees can occasionally be affected by root uptake of herbicide through movement into the top soil or by excretion of the product from the roots of nearby treated trees. Do not apply Tordon $22 \mathrm{~K}$ within the root zone of desirable trees unless such injury can be tolerated.

Do not rotate food or feed crops on treated land if they are not registered for use with picloram until an adequately sensitive bioassay or chemical test shows that no detectable picloram is present in the soil.

Do not move treated soll to areas other than those treatment sites for which Tordon $22 \mathrm{~K}$ is registered for use. Also, do not use treated soil to grow plants for which use of Tordon $22 \mathrm{~K}$ is not registered until an adequately sensitive bioassay or chemical test shows that no detectable residue of picloram is present in the soil.

\section{Woody Plants and Broadleaf Weeds Controlled by Tordon $22 \mathrm{~K}$}

Woody Plants: absinth wormwood aspen

blackberries

catclaw acacia

chaparral sp.

tringed sagebrush

gorse

Annual and Perennial Broadleaf Weeds:

\begin{tabular}{|c|c|c|}
\hline $\begin{array}{l}\text { brackentern } \\
\text { buckwheat, wild } \\
\text { buttalobur } \\
\text { bursage } \\
\text { burroweed } \\
\text { cametthorn } \\
\text { clover } \\
\text { crupina. common } \\
\text { dock } \\
\text { field bindweed } \\
\text { goldenrod } \\
\text { henbane, black } \\
\text { horsenettle } \\
\text { Carolina } \\
\text { whire } \\
\text { horseweed } \\
\text { iromweed } \\
\text { knapweed } \\
\text { dittuse } \\
\text { Russian } \\
\text { spotted } \\
\text { souarrose }\end{array}$ & $\begin{array}{l}\text { larkspurs } \\
\text { geyer } \\
\text { plains } \\
\text { tall } \\
\text { lambsquarters } \\
\text { leaty spurge } \\
\text { liconce. wild } \\
\text { locoweeds } \\
\text { lupines } \\
\text { milkweed } \\
\text { ox-eye daisy } \\
\text { pigweed } \\
\text { pricklypear cactus } \\
\text { ragweeds } \\
\text { common } \\
\text { bur } \\
\text { lanceleat } \\
\text { western } \\
\text { rush skeletomweed } \\
\text { Russian thistle } \\
\text { snakeweeds } \\
\text { sownistle }\end{array}$ & $\begin{array}{l}\text { Starthistles } \\
\text { Iberian } \\
\text { purple } \\
\text { yellow } \\
\text { St. Johnswon } \\
\text { sulfur cinquetoil } \\
\text { suntlower } \\
\text { tansy ragwon } \\
\text { tasajillo } \\
\text { toadtlaxes } \\
\text { thistles } \\
\text { artichoke } \\
\text { beaumont } \\
\text { bull } \\
\text { Canada } \\
\text { distatt } \\
\text { golden } \\
\text { tralian } \\
\text { musk } \\
\text { plumetess } \\
\text { Scotch } \\
\text { wavyleat }\end{array}$ \\
\hline
\end{tabular}

\section{Mixing and Application Methods}

Mix the required amount of Tordon $22 \mathrm{~K}$ in water and apply as a coarse low pressure spray using ground equipment or aircratt. Use enough spray volume to provide uniform coverage of the weeds. For best results treat when the weeds are growing actively in the spring before full bloom or late summer into tall. Treatments during full bloom or seed stage of some weeds may not give good control.

To prepare the spray, add about half the desired amount of water in the spray tank. Then with agitation, add the recommended amount of Tordon $22 \mathrm{~K}$ and other registered tank mix herbicides. Finally, with continued agitation, add the rest of the water and additives such as surfactants or driti control and deposition aids.

\section{Use with surfactants}

Addition of werting or penetration agems is not usually necessary when using Tordon 22K. Under extreme conditions, such as drought, addi- 
son of a surfactant may improve efficacy. However, if foliar burn occurs 100 rapidly, translocation of Tordon $22 \mathrm{~K}$ will not occur and control of perennial weeds, such as field bindweed. may be reduced.

\section{Use With Sprayable Liquid Fertilizer \\ solutions}

Tordon 22K is compatible with most non-pressurized liquid fertilizer solutions: however. If these solutions are to be sprayed with Tord on 22K. a compatibility test (jar test) should be made prior to mixing. Jar 10sts are particularly important when a new batch of fertilizer or pestiode is used, when water sources change, or when tank mixture ingredionts or concentrations are changed. Compatibility may be determined oy mixing the spray components In the desired order and proportions in a clear glass jar before large scale mixing of spray components in the spray tank. Use of a compatibility aid such as Unite or Compex may help obtain and maintain a uniform spray solution during mixing and apolication. Agitation in the spray tank must be vigorous to be comparable with jar test agitation. For best results, liquid fertilizer rates should not exceed $50 \%$ of the total spray volume. Premix Tordon 22K with water and add to the liquid fertilizer/water mixture while agitating con. tents of the spray tank. Apply the spray the same day it is prepared while maintaining continuous agitation. Rinse spray tank thoroughly aher use.

Note: Foliar applied liquid fertilizers can cause yellowing or leaf bum of crop foliage.

Local conditions may affect the use of herbicides. State agricultural experiment stations or extension service weed specialists in many states issue recommendations to fit local conditions. Be sure that use of this product conforms to all applicable regulations.

\section{Spot Treatment}

Use application rates as suggested in the "Approved Uses" section of this label of recommended by your area weed control specialist. Apply in a total spray volume of 20 to 100 gallons per acre. Make sure equipment is properly calibrated and that the amount of Tordon $22 \mathrm{~K}$ added to the spray mixture corresponds to the desired rate and spray volume.

To Callbrate:

1. Measure an area $18.5 \mathrm{tt}$ by $18.5 \mathrm{ft}$ in the target application area.

2. Spray the measured area uniformly with water only and record the number of seconds required to cover the area.

3. Measure the amount of water delivered to the test area by spraying into a container for this amount of time.

4. The amount of water collected in fl $0 z$ equals spray volume in gallons per acre.

5. Refer to the chart below for the amount of Tordon $22 \mathrm{~K}$ to $\mathrm{mix}$ at the spray volums indicated by the calibration proceciure. This chant contains the amount of Tordon 22K 10 mix when the application rate is 1 quart per acre. For a rate of $1 / 2$ quart per acre ( 1 pint). divide the amount in the table by 2 . For an application rate of 2 quarts per acre. multiply the table value by 2 .

\begin{tabular}{|c|c|c|}
\cline { 2 - 3 } \multicolumn{1}{c|}{} & \multicolumn{1}{|l|}{$\begin{array}{l}\text { To Apply the Equivalent of } 1 \text { Quart of Tordon 22K } \\
\text { per Acre at the Spray Volume Indieated, Mix the } \\
\text { Following: }\end{array}$} \\
\hline \begin{tabular}{|c|c|} 
Spray Volume \\
(gallons per acre)
\end{tabular} & $\begin{array}{l}\text { Amount of Tordon 22K } \\
\text { per } 1 \text { gallon of water }\end{array}$ & $\begin{array}{c}\text { Amount of Tordon 22K } \\
\text { per } 100 \text { gallons of water }\end{array}$ \\
\hline 20 & 10 tsp & 5 quarts \\
40 & $43 / 4$ tsp & 2 quarts \\
60 & $31 / 4$ tsp & 123 quarts \\
80 & $21 / 3$ tsp & $11 / 4$ quarts \\
100 & 2 tsp & 1 quart \\
\hline
\end{tabular}

Note: $\quad$ tsp $=$ teaspoon

6 tsp $=1$ fluid ounce

Do not exceed 4 quarts per acre in eny one year as a apot treatment.
Tank Mixture for Spot or Broadeast Treatment of Susceptlble Woeds

Tordon 22K may also be tank mixed with 2,4-D products or other regis tered herbicides for use on areas having mixed species including those which respond well to 2.4-D. Read and follow all directions and use precautions on other product labels.

\section{Wick Application}

Mix 1 part of fordon 22K with 2 parts of water to prepare a 33\% solution. Apply when weeds are actively growing and are above most desirable olants. For iromweed and goldenrod, best results are obtained with applications made prior to early bud stage. Wick applieator should be drained and cleaned after each use. Ropes should be changed when flow is reduced from wear, extended use, poor cleaning or intermittent uso.

\section{APPROVEDUSES}

\section{NON-CROPLAND AREAS}

Use Tordon 22K to control susceptible broadleaf weeds and woody plants on non-cropland areas such as on roadsides or other rights-ofway. along fence rows, and asound farm buildings. Use up to 2 quarts of Tordon 22K per acre as a broadcast treatment and up to 4 quarts per acre as a spot treatment. Wick Application may be used on non-cropland. See "Wick Application" In "Mixing and Application Methods" section for directions.

\section{RANGELAND AND PERMANENT GRASS PASTURES}

Use Tordon 22K on rangeland and permanent grass pastures to control susceptible broadleaf weeds and woody plants such as (but not limited to) those shown in the table.

Grazing Restrlctlons: When applying more than 1 quart of Tordon 22K per acre, do not cut grass for feed within nwo woeks after treatment. Meat animals grazing for up to two weeks atter treatment should be removed from treated areas three days prior to slaughter. Do not graze lactating dairy animals on treated areas within two weeks after treatmont.

\section{Broadcast Treatment (Ground and Aerial Applications)}

Tordon 22K can be applied as a broadeast treatment by oround or aerially to control several broadleaf weeds and woody plants. Apply Tordon 22K at the suggested rates in 2 or more gallons of water per acre by air or in 10 or more gallons of water per acre by ground. Re-treat as necessary but do not exceed 1 quart of Tordon $22 \mathrm{~K}$ per acre per season. For control of actively orowing susceptible annual broadleaf weods. including Russian thistle, apply $1 / 4$ to $1 / 2$ pint per acre of Tordon 22K. Tordon 22K can also be tank mixed with $1 / 2$ to 1 pound per acre 2,4-D where species present are sensitive to 2,4-D.

Tordon 22K at rates over 1 quart may suppress certain established grasses. such as bromegrass, bluegramma, and buffalograss. However, subsequent grass growth should be improved by release from woed competition. 
Weed Control Guidelines for Tordon 22K in Non-cropland, Rangeland and Pasture.

\begin{tabular}{|c|c|c|}
\hline Weed Species". & Rate per Acre & Comments \\
\hline $\begin{array}{l}\text { biennial thistles } \\
\text { bull } \\
\text { musk } \\
\text { plumeless } \\
\text { Scotch }\end{array}$ & $\begin{array}{c}\text { Fall: } 1 / 2 \text { pint } \\
\text { Spring: } 6-8 \mathrm{H} \text { oz with } \\
1.0 \mathrm{lb} \text { ae } 2,4-\mathrm{D}\end{array}$ & $\begin{array}{l}\text { Apply when thistles are in } \\
\text { the rosette stage before } \\
\text { bolting in the spring or in } \\
\text { the fall prior to soil } \\
\text { treeze up. }\end{array}$ \\
\hline bolted musk thistle & $\begin{array}{c}1 / 2-1 \text { pint }+1 \mathrm{lb} \text { ae } \\
2.4-\mathrm{D} \text { per acre }\end{array}$ & Apply before flowering. \\
\hline $\begin{array}{l}\text { broom snakeweed } \\
\text { geyer larkspur } \\
\text { locoweeds } \\
\text { muttiflora rose } \\
\text { plains larkspur } \\
\text { prickly pear cactus } \\
\text { sulfur cinquefoil }\end{array}$ & 1 pint & $\begin{array}{l}\text { For pricklypear cactus. } \\
\text { use of a diesel oil-water } \\
\text { emulsion spray mixture } \\
\text { may improve control. }\end{array}$ \\
\hline $\begin{array}{l}\text { black henbane } \\
\text { crupina } \\
\text { diffuse knapweed } \\
\text { spotted knapweed } \\
\text { yellow starthistle }\end{array}$ & $1 \cdot 2$ pints & \\
\hline $\begin{array}{l}\text { absinth wormwood } \\
\text { bursage } \\
\text { Douglas rabbitorush } \\
\text { goldenrod } \\
\text { ox-eye daisy }\end{array}$ & $1 \cdot 2$ pints & $\begin{array}{l}\text { Tank mix the lower rate } \\
\text { with } 1.0 \text { tb ae per acre } \\
2.4-0 . \\
\text { Lower rates may } \\
\text { require annual spot } \\
\text { treatments. }\end{array}$ \\
\hline wild liconce & 1 quan & \\
\hline $\begin{array}{l}\text { Canada thistle } \\
\text { field bindweed } \\
\text { gorse } \\
\text { lupines } \\
\text { nush skeletonweed } \\
\text { St. Johnswort } \\
\text { tansy ragwort }\end{array}$ & 1.2 quants & $\begin{array}{l}\text { Tank mix the lower rate } \\
\text { with } 1.0 \text { ib ae per acre } \\
2,4-0 \text {. } \\
\text { Lower rates may } \\
\text { require annual spot } \\
\text { treatments. }\end{array}$ \\
\hline $\begin{array}{l}\text { dalmation toadflax } \\
\text { juniper } \\
\text { perennial sowthistle } \\
\text { Russian knapweed }\end{array}$ & 2 - 3 quans & $\begin{array}{l}\text { For Russian knapweed. } \\
\text { apply at bud stage or in } \\
\text { the fall }\end{array}$ \\
\hline $\begin{array}{l}\text { tall larkspur } \\
\text { yellow toadfiax }\end{array}$ & 3.4 quarts & \\
\hline leaty spurge & 1.4 quarts & $\begin{array}{l}\text { Lower rates will require } \\
\text { annual retreatment for } \\
\text { several years. Retreat } \\
\text { when control drops } \\
\text { below } 80 \%\end{array}$ \\
\hline
\end{tabular}

- For additional species or more specific rates consult your area's current Weed Control Guide and/or your local DowElanco representa. tive.

- Many seedling annual weeds can be controlled using 1 pt per acre.

For rates exceeding 1 quart per acre, apply oniy as a apot treat. ment and the total area treated in a single season ahould not exceed $25 \%$ of a landowner's acreage tound In any particular watershed.
Spot Treatment

See "Spot Treatment" in "Mixing and Application Methods" section for directions for calibration, spray volume determination and mixing.

\section{Spot Concentrate Application}

Eastern red cedar can be controlled with spot concentrate applications of Tordon 22K in either the spring (April-May) or fall (SeptemberOctober). For best results. use $3 \mathrm{ml}$ to $4 \mathrm{ml}$ of Tordon $22 \mathrm{~K}$ (undlluted) per 3 feet of plant height. Application should precede periods of expected rainfall. Apply directly to soil within the dripline and on the upslope side of the tree. Application to trees taller than 15 feet is not recommended. Do not use more than 2 pints of Tordon 22K per acre in any one year.

\section{Wick Application}

See "Wick Application" in "Mixing and Application Methods" section for directions. Apply when woeds are actively growing and are above most desirable plants. For ironweed and goldenrod. best results are obtained with applications made prior to earty bud stage.

\section{Barley, Oats, and Wheat Not Underseeded With a Legume (Which is Not Flood or Sub- Irrigated and Not Rotated to Broadleaf Crops)}

Use Tordon $22 \mathrm{~K}$ for the control of susceptible annual broadleaf weeds such as (but not limited to) volunteer sunflower, wild buckwheat. lambsquarters, pigweed, Russian thistle, and sowthistle.

\section{Use Precautions \\ Do not apply Tordon $22 \mathrm{~K}$ within 50 days before harvest.}

Spray mixtures may cause shorter straw on some varieties of cereals but grain yields are usually not affected.

Do not graze or feed forage from treated areas for 2 weeks after treatment. Do not havest hay from treated grain fields.

Use only on land that will be planted the following year to grass. barley. oats. wheat or fallowed. Do not apply more than $11 / 2$ fluid ounces of Tordon $22 \mathrm{~K}$ per acre during the small grain growing season.

\section{Broadcast Treatment (Ground and Aerial Applications)}

Tordon 22K can be applied as a single broadcast treatment by ground or aerially to control several broadleaf weeds by itself or as a tank mix with 2,4-D, MCPA, or sulfonylurea herbicides such as Ally. Apply Tordon $22 \mathrm{~K}$ at the rates suggested in the following table in 2 to $5 \mathrm{gal}$ lons of water per acre by air or in 51020 gallons of water per acre by ground. The addition of surfactants may aid control under dry conditions, but may cause injury to grain if used over the top. Read and fol. low directions and precautions on other product labels when tank mixing.

\section{Spring Wheat, Barley and Oats}

Apply from the 3 to 5 leaf stage to the early jointing stage of growth as indicated in the table below. Applications at the 3 to 5 leat stage occasionally cause slight head malformations and straw shortening but nor. mally do not aftect yield.

\section{Durum Wheat}

Do not treat durum wheat since some varieties of durum wheat may be injured.

\section{Winter Wheat and Barley}

Apply atter resumption of active growth in the spring until the early jointIng stage. 


\begin{tabular}{|c|c|c|c|c|c|}
\hline \multicolumn{6}{|c|}{ Use Rates for Wheat, Barley and Oats } \\
\hline \multirow[b]{2}{*}{ Weeds } & \multirow[b]{2}{*}{$\begin{array}{c}\text { Weed Growth } \\
\text { Stagett }\end{array}$} & \multirow{2}{*}{$\begin{array}{c}\text { Graln Growth } \\
\text { Slage }\end{array}$} & \multicolumn{3}{|c|}{ Amounts of Each Product Per Acret+t } \\
\hline & & & Tordon 22K & $\begin{array}{l}4 \text { Ib ae/gal } \\
2,4-D \text { or } \\
\text { MCPA }\end{array}$ & $\begin{array}{l}6 \text { lb ae/ga } \\
2,4-D \text { or } \\
\text { MCPA }\end{array}$ \\
\hline \multirow{2}{*}{$\begin{array}{l}\text { More susceptible } \\
\text { species. such as: } \\
\text { lambsquarters } \\
\text { pennycress } \\
\text { wild mustard } \\
\text { mayweed }\end{array}$} & 3 inches & $\begin{array}{l}3105 \text { leat to } \\
\text { earty tillering }\end{array}$ & 11102 & $1 / 2$ pint & $1 / 3$ pint \\
\hline & 3 to 6 inches & $\begin{array}{l}\text { Tillering to } \\
\text { earty jointing }\end{array}$ & $11 / 2 \mathrm{HOZ}$ & $3 / 4$ pimt & 1/2 pint \\
\hline $\begin{array}{l}\text { Less susceptible } \\
\text { species such as: } \\
\text { volunteer sunflower } \\
\text { wild buckwheat } \\
\text { Russian thistle } \\
\text { pigweed } \\
\text { Canada thistle, top } \\
\text { growth } \\
\text { suppression }\end{array}$ & 1 to 6 inches & $\begin{array}{l}\text { Tillering to } \\
\text { early jointing }\end{array}$ & $11 / 2 \| 02$ & $3 / 4101$ pint & $1 / 2$ to 2/3 pint \\
\hline
\end{tabular}

tFor oats, do not tank mix with 2,4-D herbicides.

+ For best results, treat when weeds have 2 to 4 leaves and are actively growing.

$+t+$ When measuring small amounts of Tordon $22 K$, special care should be taken not to exceed suggested rates.

\section{FALLOW CROPLAND (NOT ROTATED TO BROADLEAF CROPS)}

Apply Tordon $22 \mathrm{~K}$ as a post harvest or fallow treatment in continuous grain or during the fallow period. Tordon $22 \mathrm{~K}$ may be applied alone or in tank mix combination with 2,4-D or other herbicides registered for this use. Apply in 2 or more gallons of water per acre by air or 5 or more gallons per acre by ground. Spray only under conditions that will prevent injury to nearby susceptible crops or ornamentals. Refer to "General Use Precautions" section for information on preventing dritt to oft-target areas.

\section{Appiication Rates}

Note: Do not apply more than 1 pint per acre as a broadeast treatment in any calendar year.

Annual Weeds: To control annual weeds such as Russian thistle and wild buckwheat. apply $1 / 4$ to $1 / 2$ pint per acre of Tordon 22K in tank mix combination with $1 / 2$ to $1 \mathrm{lb}$ ae of 2.4-D ur other herbicides registered for use on fallow land. Apply when weeds are actively growing.

Fleld Bindweed: Apply 1/2 to 1 pint por acre of Tordon 22K plus 1/2 to $1 \mathrm{lb}$ ae per acre of 2,4-O when bindweed is actively growing. Optimum time for treatment is when plant runners reach 8 to 12 inches. Use $1 / 2$ pint per acre to control light to moderate infestations under good growing conditions or to reduce the potential for crop injury. Use higher rates for heavy infestations and longer term control. Some regrowth will occur the following season and a re-treatmem program for successive years is recommended.

Canada thistle: Apply 1 pint per acre of Tordon 22K plus I Ib ae per acre of 2,4-D when the majority of thistle plants are emerged but priot to bud stage.

\section{Crop Rotation}

Use only on land to be planted the following year to grass, barley, oats. wheat or fallowed. Many broadleaf crops are extremely senstive to soil residues of Tordon 22K. Do not plant sensitive broadleaf crops for 36 months after treatment or until soil residues have declined to a safe level as indicated by an adequately sensitive bioassay using the Intended broadleaf crop. A bioassay is recommended following treat ment prior to planting any sensitive broadleaf crop.

\section{Preplant Interval}

A preplant interval following Tordon $22 \mathrm{~K}$ application prior to planting small grains is recommended to reduce or eliminate potential crop injury and/or yield reduction. The possibllity for crop injury or yield reduction to occur depends on application rate, soil organic matter. rainfall, temperature and incidence of cereal diseases. Adequate soil moisture and soil temperature during the preplant interval is important in reducing, but may not eliminate. the risk of crop injury. When considering use of Tordon 22K on fallow land. growers should consider the benefit of weed control against the risk of crop damage and treat only if the risk of injury to small grains can be tolerated. The following preplant intervals are recommended:

For applleationa up to 1/2 plnt per ace, allow a minimum of 45 days of soil temperatures above $40^{\circ} \mathrm{F}$ between application and plaming.

For applleatlons of greater than 1/2 plnt and up to 1 plnt per acre, allow a minimum of 60 daya of soil temperatures above $40^{\circ} \mathrm{F}$ between application and planting, except in the states of Idaho. North Dakota. Nebraska, Montana, Oregon. South Dakota. Washington and Wyoming, where the minimum preplant interval is 90 days.

Spot Treatment

See "Spot Treatment" In "Mlxing and Application Methods" section for directions for calibration, spray volume determination and mixing.

Spot treatments of Tordon $22 \mathrm{~K}$ at rates over 1 pint per acre can be made on fallow, non-irrigated cropland if the treated areas comprise less than $10 \%$ of the Immediate field in any one year. Tordon $22 K$ should not be applied to cropland at rates exceeding 2 quarts per aere. When Tordon 22K at rates above 1 pint per ace are applied, injury to small grains may result for periods up to two years ater treatment.

\section{CONSERVATION RESERVE PROGRAM (CRP) FOR SEEDING TO PERMANENT GRASSES ONLY}

Do not use Tordon 22K If legumes are a desired cover during CRP.

Conditions that stress grasses. such as drought, will increase potential for injury to the grass at all stages of growth.

To reduce potentlal damage to aubsequent small graln crops, use the lower rate or discontlnue the use of Tordon $22 \mathrm{~K}$ at least 2 years prior to the seeding of small grain crops. After CRP, do not plant broadleaf crops in treated acres until an adequately sensitive bioassay shows that no detectable pictoram is present in the soil. 


\section{Broadcast Treatment (Ground and Aerial Applications)}

Applications of Tordon 22K should be made atter perennial orasses are well established (have developed a good secondary root system and show good vigor). Most perennial grasses show improved tolerance to the herbicide at this stage of development.

For control of actively growing perennial weeds, use up to 1 quart per acre of Tordon 22K atter the grass is established. For best resutts, use in 2 or more gallons of water per acre by air or in 5 or more gallons of water per acre by ground. Increasing the rate of application can increase the risk of injury.

For control of actively growing susceptible annual broadleat weeds. (including Russian thistte) apply $1 / 4$ to $1 / 2$ pint per aere of Tordon $22 \mathrm{~K}$. Tordon 22K can also be tank mixed with $1 / 2$ to 1 pound per acre of 2,4D where 2,4-D sensitive species present. Read and follow all directions for use and use precautions on other product labels.

\section{Spot Treatment}

See "Spot Treatment" in "Mixing and Application Methods" section for directions for calibration, spray volume determination and mixing.

For spot applications when perennial grasses are established, use 1 to 8 pints per acre of Tordon 22K. Rates of 2 quans per acre or more should only be used for control of deep-rooted perennial broadleat weeds.

Tordon 22K at rates over 2 pints per acre may suppress certain established grasses such as bromegrass, blueoramma and butfalograss. However, subsequent grass growth should be improved by release trom weed competition.

\section{Wick Application}

See "Wick Application" in "Mixing and Application Methods" section for diréctions. Apply when weeds are actively growing and are above most desirable plants. For ironweed and goldenrod. best results are obtained with applications made prior to earty bud stage.

\section{Warranty Limitations and Disclaimer}

DowElanco warrants that this product conforms to the chemical description on the label and is reasonably fit for the purposes stated on the label when used in strict accordance with the directions, subject to the inherent risks set forth below. DOWELANCO MAKES NO OTHER EXPRESS OR IMPLIED WARRANTY OF MERCHANTABILITY OR FITNESS FOR A PARTICULAR PURPOSE OR ANY OTHER EXPRESS OR IMPLED WARRANTY.

\section{Inherent Risks of Use}

$h$ is impossible to eliminate all risks associated with use of this product. Plant injury, lack of performance, or other unintended consequences may result because of such factors as use of the product contrary to label instructions (inctuding conditions noted on the label, such as unfavorable temperature, soil conditions, etc.), abnormal conditions (such as excessive rainfall, drought, tornadoes, hurricanes), presence of other materials, the manner of application, or other factors, all of which are beyond the control of DowElanco or the seller. All such risks shall be assumed by Buyer.

\section{Limitation of Remedies}

The exclusive remedy for losses or damages resulting trom this product (inchuding claims based on contract, negligence, strict liability, or other legal theories), shall be limited to, at DowElanco's election, one of the following:

1. Refund of purchase price paid by buyer or user for product bought. or

2. Replacement of amount of product used.

DowElanco shall not be liable for losses or damages resulting from handling or use of this product unless DowElanco is promptly notified of such loss or damage in writing. In no case shall DowElanco be liable for consequential or incidental damages or losses.

The terms of the "Warranty Disclaimer" above and this "Limitation of Remedies" cannot be varied by any written or verbal statements or agreements. No employee or sales agent of DowElanco or the seller is authorized to vary or exceed the terms of the "Warranty Disclaimer" or this "Limitation of Remedies" in any manner.

- Trademark of DowElanco

DowElanco - Indianapolis, IN 46268, U.S.A.

\section{LABEL CODE 112-42-002 DATE CODE 292}

EPA APPAOVAL 12/20191 REPLACES $112-42-001$

Revisions include:

1) Label reformatted and edited for clarity.

2) Updated woody plants and broadleaf weeds controlled listed. 


\section{Specimen Label}
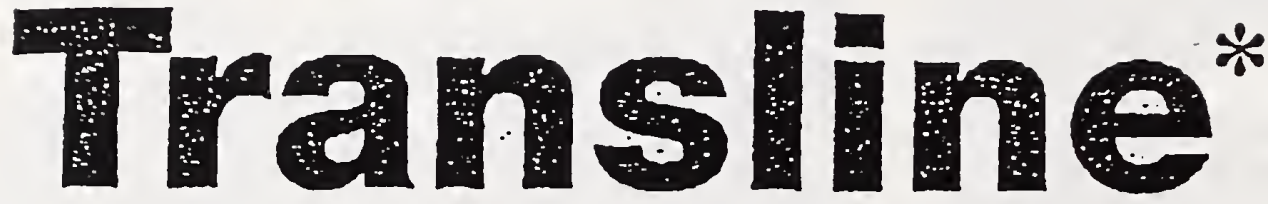

Herbicide

For Selective Control of Broadleaf Weeds in Non-Cropland Areas, Industrial Manufacturing and Storage Sites and Rights-of-way

Active Ingreolent(s):

Clopyralid (3.6-dichloro-2-pyridinecarboxylle aele) 83 the monoethanolamine salt

inert Ingredieni(s):

ACIO EOUIVALENT:

3.6-diehloro.2-pyridinecarboxylic acid. $31 \%$ - $3 \mathrm{lb} / \mathrm{gal}$

E.P.A. Registratlon No. 62719.73

E.P.A. EsI. $464 \cdot M 1 \cdot 1$

KEEP OUT OF REACH OF CHILDREN

CAUTION

\section{PRECAUCION:}

\section{PRECAUCION AL USUARIO:}

Si usted no loe inglos. no use este producto hasta que la etiquete to hoyo sido explicada emplianente.

PRECAUTIONARY STATEMENTS Hazards so Humans and Domestic Animals CAUSES EYE INJURY • HARMFUL IF INHALED OR ABSORBED THROUGH SKIN

Avoid Contact With Eyes, Skin Or Clothing

- Avoid Breathing Spray Mist - Wash

Thoroughly With Soap And Water After Handling - Remove Contaminated Clothing And Wash Beforo Reuse

STATEMENTS OF PRACTICAL TREATMENT: $H$ In OYOS, hush with plenty of water. Ges medied atrention II fritustas parsists. If on okin. wash with plenty of eopp and woter.

Get medical attention.

Physical or Chemical hazards

COMBUSTIBLE - Do Not Use or Store Near Heat or Open Flame. Do Not Cut or Weld Container.
Environmental Hazards

Do not conzamina:e water whan oisposing of equipment washwators. Do not contaninate viater usod lor Inlgatler or domosite surposes. Do nor apoly directly io any sody of water of wedlends.

See additional precautionary statements elsewhere on this label.

\section{NOTICE}

Read and understand the entro labal tefore using. Use only according to label directions.

Boforo buying or using this product, nad WARRANTY LIMITATIONS ANO OISCLAMMER" elsewhern on inls labol. If terms are not aceeptable, rotum unoponod peckage at once to sollor for full refund of purchase prtee paic. Otharwise. usa by the buyer or any other usop constrivies eceoplanes of the torms und or WARRANTY UMMTATIONS ANO DISCLAIMER

IN CASE OF AN EMERGENCY ondangering life or property involving this product, call collect 517.636-4400 AGRICULTURAL CHEMICAL Do Not Ship or Store with Food, Feeds, Drugs, or Clothing 


\section{DIRECTIONS FOR USE}

$H$ is a violotien of Federal lew to use this proctict in a manner inconsistent with lis labeling.

Do not apply this produet inrough any type of Iitigation sysiem.

TRLNSLINE Herblelde is recommenced for celectlve, posiomergence control of the tollowing broadleat woods in ron-cropland areas Ineluding equipment peithways, Industria manulaciuring and storage sites and righis-of-way such as along roodsides, lectrieal power linos, communlestlon lines. ispolines and railrosds.

\section{acseras}

nrichoke. Jerusalem

I8cysthumb'

injekwheas. will

vurislobur'

Durdock, common

Cinada inlstie

(rosetto to bud)

er.smomile, lolse (scontlezs)

cramomilo. maywood

(cogtennen

clover. swoot

clovar, red

cockilobur, common

colfoowrood

cornflower

(bachalor burlon)

candelion

oock, euny

grourcsel, carmmon

niswiksbeard. narrowloal

nossowoed

umsonwoed

knapweed; diffuse

knapweed. Russian"

knapwood, spettod

letives. priekly

becoweed, white

locowoed, lombort

mersholder

mosquthe

musk thistlo (rosotte :o bud)

nighishado. Eestorn blgek

nightehsoe. curleal

nlghishade. hainy

exeye calsy

plneapoleweod

rogiveod, common

requeed, giant

colsity, mosdow (gostsbeard)

sicklepod

smarivood. groen'

sorral. red

sownistle. annus

sowthistle, porennial'

starthistle, yellew

sunflower (connon and wild)

thistle. Cansda

thistlo, must

voteh

'These weecs may ony be supseresed. Supsressisn is a vioun roduetien in wood compotition (recueco posulation or vigon as combaros to untroetod erees. The degroe of weod comrol and curstion of ofleet will very with wood gice and denairy, eproy rate and coverspa, and prowing conditions botero. during. end atter the time
uf ivestment.

For pcronnial woods, TRANSLINE Herbielde wlll centrol the mutisl topgrowth and inhibit reprowth during the soesen of application kesson- long controf. At higher wse ratos shown on this label. TRANSUNE Herbicide may catse a roduction in shoot regrowth in the seasen following applicetion; howover, plant response my by incensistent due to inherent verlability in ahoot rogrowat frem perennilal poot systoms. Timing: Apply to actively groving weeds. Extrome growing cenditions sueh es drowght or near freozing temporatures proor 10, al. and following tim of applieation may rudues wued control. Onty woeds which arv emerged at the tine of applleation will be affocted. Wot foliage at the time of esplication may decrease control. The treatment with TRANS UNE Herbicide will be reinfest within $6-8$ hours aher applleatlon.

Rato: Generally, lower labelod epplication rates will bo satistactory lor young. auceulent growh of sensitive wood spocies. For loss sensitive species, perenniels, and under conditions where control is more difleut folant stross conditions sueh as drought or extrome temperatures, donse weed stands. and/or lopes woeds), the higher rates will bo nerded.

Coveroge: Adequste sproy coverepe and drith control are important. Obtaining bolance batween sproy coveroge and drift control may sometimes be difficut but can be achlovod provided the applietor uncerstands the foctors affecting coverege and drith. Facter effesting spray coverege include spray volume, and weed density. As weed density inereases, spray volume should be increased to obtein equivalent weed control. Feior to menufaeturer's rocommondations for intormation on the ralationship betwoen gallons por aer. spray pressure, sproyer spood, nozzle type and artangement, nozale hoight ebove the torget cenopy, droplet size. and drift potentlal for respoctlve epplleation equipmont. Use equipment and nozzle types whlch are designed ter herolelce applicaston. Roducing total spray volume mey result in decrossod coversoo and wood control. Use enough total sproy volume and a doltuory system to provide thorough coverage and a unlform spray pattepn. Do nol epply where spray ditt may be a problem due 10 proxtmity of usceptlblo erops or other deslrable plants. Uso of Adfuvants: Additlon of autactants, erop oils, or Oihar adjuvants is not usually necessary whon using TRANSLINE Horbleide. Adolng a surtzetant to the spray mixture may ir.eresso oflectlvoness on woods. Il an adjuvant is edeed to the spray solution. follow all manutacturor use gutdelines.

Tank Mixcs: When lark mlxing, read ânc follew the lobel ol odeh wak. mix product used tor precaullonary staiements. diroctlons lor usa, woods controled, and googrophis and other rostrictions. Uso in oceordance with the most resirietive of labol limilotlons and procautlons. No bobal dosages should be excescod. This product cannot bo mixed with ony product centalning a label prohibition soainst such mixing.

\section{Non-Cropland}

For use on non-cropland areas such as industrial monufacturing and storage sites and rights-ot-woy sueh ss along roadaldos, eloctrical powor llnos. communication linos, pipolines and roilrosds. Broedeast Application (Ground): For contrel of oroacleal weods, apply $1 / 4$ to $11 / 9$ plnte of TAANSLINE Herblelde per acre (equivalont to 0.09 to 0.5 lbs ae per acro). Non-lende surfactnit snowlo be used in sprey mixtures at i 102 quans per 100 oallons of sproy mixlure. The lower rate of $1 / 4$ pint por ace provides ecceplable control of weeds onty under highly favorable plem growing conditions and whon plants are no larger than 3 to 6 inehes tall. Where Canada inisile or knspwoods are the primary post, bost results aro obtoinod by epplying $\% / 3$ to $1 \%$ pinis of TRANSLINE Herbiclde por acre aftor basal bavos are produced. For roedside applleations, sprey volumes of 25 to 50 gallons per acre will ersur edequate coverage. Addition of $\%$ to 1 ounce Telar por acre rray enhanse thistle control when low rases of TAANSLINE aN USEd. TRANSLINE Herbictde can be lank mixed whth diesel of or equivalont inven egens spproved fof use on agrieultural erops. Esteahsnes gresses aro tolerant bur now grass seodlings may be Injured to varying degrees unit the grass has become well establlshoe.

Heh-Volume Leat Stom Treatment (Woody Plants): For control of brush, Use 11 to 3 quans of TRANSUNE Herbleide per 100 gatlons of total spray solution. Thorough coverage le necesay for good results, therelore. epply es e complete spray-towet foliar applieation, ineluding an feavos, stoms, end roor coltars bus do nor axceed epplieatlon of mare then i $1 / 2$ plnts of TRANSLINE Herbletde per acre. To mininize drit. use a maximum spray pressure of 50 psl and keep spray no hlgher than the tree erowns. Trees toller than 8 fees in holght moy bo hard to traet officionty and to oblain necessary covrage.

Do not apply by ais.

Unsatisfactery control may resuh 18 epplieation is modo whon brush and weeds are under sovere drought atress or cther conditions that inhiblt good growh. Environmental conditlons may influence resules conslderably. For best rauts on mesquite, eppty in the sprine or carty summer during the period 40 10 90 daye after the first oroen promth appears and when soil moisture is edequete tor pood growth Soil temparatures of $75^{\circ}$ to $83^{\circ} \mathrm{F}$ of 212 to 18 insh depth oro optional for pood plant kills. Soll temporciure of less then $75^{\circ} \mathrm{F}$ et this depth will roduse the uttlmate root $\mathrm{kil}$ of mesquite. 


\section{USE PRECAUTIONS}

This product cen affoct susceptiblo brosdloal plan's drectly through toliage and indlroctly by root uptake íron treated soll. Thoratoro. do nol soply TFANSLINE Herbieide cirectly lo or allow soray ditt to cone in contsel with vecstsbles. nowers. grepos, tomotoes, po:atoes, beans, lentils, peas. attal!3, sunflowers, soybeans, samllewor, or cther desirable orozdieat crops and ornemental plants or soil witiero these sonsrive crops wall be planted the same seasen.

De not contaminato isrigatlon dltehes or woter used for irrigation or domostle purposos.

Avold Spray Oritt: Appllestions snould be mosto to avoid sproy ofith sukeu very smial quantitlos of the ypray, whlch moy not be visible. may soverely Injure susceptiole crops during boin growing and cormant porlods. Use coarse spreys 10 mininize delt since, under edverse woether coneltions. line sopay droplats may drift a mile op roro. $A$ ceit conirol or deposttion apent such as Nalec-Trol may be usod us:ri tnis prodiset to ald in reduelng sproy cflth. Il used. lollow all use recommendavons and procautions on the produe: label.

Ground Appllestlon: To minimize sproy ditm, eppty TRANSLINE Herbielco in a total sproy volume of $y 0$ or more gallons per aere as large-droplot. low-pressure spray. Roter to manufaelurep'y recomranda:lons for additional Inlomation on gallons per aers, spray pressure, spreyer sposo. nozzlo types and arangoments, nozale helghts above the tareat canopy. otc., for rospeethe applieatlon equlpment. With ground equipment. spray drit cen be lessened by keepling the sproy beem as low as pessibie: by using no more inan 30 pounds spreythg pressure with lares droplet. produeng nozzle lips; by spraying when wind velociny is low; and by stopoing all spraythe whon wind exceeds 6 to 7 miles per hour. Do nol apply with hollow cono-type insecticide or oiner nozzles that produee a fine-oroplet spray.

Do not asply by oleerart.

Do Not Transter Llvostosk from treated srazing aross ento sonsitivo breseleat crop aross without first cllewing 7 ceys of graslne on an un:sested oesture. Othenvise. urine may contaln enough clopyralld to cause Injury to sonsitive Drodsloaf plants

Straw trem trested areas, of menure from enima's that have grazod veated aroas, cannot be used for compesting or mulehing on ground where suseepulble ereps may ko grown the following seoson. To promote herblatde decermposition, plant matenal should be oventy incorporated er bumed. adecuare moisture is also requlred to promote broakdown of plani residues vithen eonialn cleoyralid.

Do not use in a groonhouse. Excesstve aneunts of this herbicide in the soll may temporanily inhiblt seed germination or plans growth.

\section{Spray Equipment - Cleaning Instructions}

To ovold iniury to deslrable plants, equtpment used to apply TRANSUNE Herbierde chould be thoroughly eleaned bolore' rousing to 2oply any other ehemteals.

1. Rinse and thush eppllestlon equipment tharoughty attop use et least three ilmes with water, and dispose of plase worer in non-cropland area oway from waser susplles.

2. Durine ine second rinse, add 1 at of housonoid ammonia lor every 25 gallons of wotor. Circulate the solution inrough ine entire system 20 that all Intomal surfaces are coniseted (15.20 min.). Lot the solution stand for sovaral hours. seelurinsly overnight.
3. Flush the solution out the spray tank throuph the boom.

4. Alnse the systom iwice with clean wetor, reclrculating and draining each timo.

5. Nozzles and sereens shoutd be removas and cleanao soparsiely.

\section{PRECAUTIONARY STATEMENTS}

Environmental Hazards

Clopyralld is a chomieal which ean travel (seep or leaen) through soil and under cartaln conditions conteminote groundrater which may be used for irrigatlon of drhking purposes. Usors are advised not to opply clopyralld whoro soils hove a rapld to very rsple pormoablly ineouphout int profile (such as loemy and to sand) and the water lable of an undertying equifer is shallow, $\alpha$ io solls containing sinkholes over limestone bedrock, severely frselured surfaces, and substratas which would allow drect introduetion into an aquitor. Your loed agrteutlural egonelas can provide lurther information on the type of soul in your area and the location of ground water.

STORAGE AND DISPOSAL

Do not centamina:e wator, tood or feed by storage or dlsposal.

Storsga: Store above $28^{\circ} \mathrm{F}$ os warm ro $40^{\circ} \mathrm{F}$ and agtente bolore use.

Pesticido Dlsposali Vrostes rosuting from the use of this product may be disposed of on alie of et an approved ivestn disposal reciliny.

Contalner Olsposal (Metal): Do not reuse container. Trtolo inse (or equivalent). Puncture and dispose of th a sanitary lanofil, or by other procoduras approved by state and local euthorttles.

Centainor Olsposal (Plastie): Do not reuso contalner. Thiple rinso. (or oquivalent). Puncture and dispose of la a scnitary lanofll, $e$ by lnetheratien, Or, H allowod by state and beal authorltles, by burning. II burnod, stay out of smuke.

WARRANTY LIMITATIONS AND DISCLAIMER

DowElanco warrants that this froduet conforms 10 the enomieal desertetion on the labol and is ressonably fit for the purposes stated on tho labol whon usod in strict secereance with the drectons therein under normal condtions of use. THIS IS THE ONLY WARRANTY MADE ON THIS PRODUCT. NO OTHER EXPRESS AND NO IMPUED WARANTY OF MERCHANTABUTTY OR FINESS FOR A PARTICULAR PURPOSE IS MADE OUTSIDE OF THIS LABEL

Therofore. nelther this warranty nor any othor warrenty of merchanzabilty or fitness for a partieular purpose, express or Implied, extends to the use of this product contary to label instruetlons finchuding condliom noted en the labol, sueh as untavorable temperatures, soil conditlons, ote.), undop abnomal conditions (such as excessive rainiall, drought. tomadoes, hurrieanes, ote) $\alpha$ under conditione not reasonably foreseeable 10 or beyond the centrol of seller. When buyor or user autfers losses or dannges resuttho from the use or handing of this product finchucino claims baseo on contract, negllgonee, striet llabilthy, or other logal theories), buyer or usor must prompthy nottly in writho DowElanco of any elalms to be oliplblo to reetve other remody glvon bolow. Th. EXCLUSIVE REMEOY OF THE BUYER BR USER and tho LIMIT OF LLABILTY of DowELIanco or any othor solke will be one of the following, as the tioction of Dowelonco:

(1) Retund of puretrose price pald by buyce or user for produet bought, or

(2) Roplecomont of emount of proctuct used.

The sollor will not be hablo for consequential or theidons damages or losecs. 
Tho sorms of this Worronty Limizatiens And Disclajmer cennot be varied by any written or verbal statomonts er agreornents. Any employee or sales agent of the seller is nos authorized to vary or exeped the lorms of this Warrary Uiritatlans AnO Disclaimer in any mannor.

$11388 . \mathrm{LI}$

280

\section{DowElanco}

Indianapolie, InElana $462 \varepsilon B$ U.S.A

- Tradomark of DowElaneo 


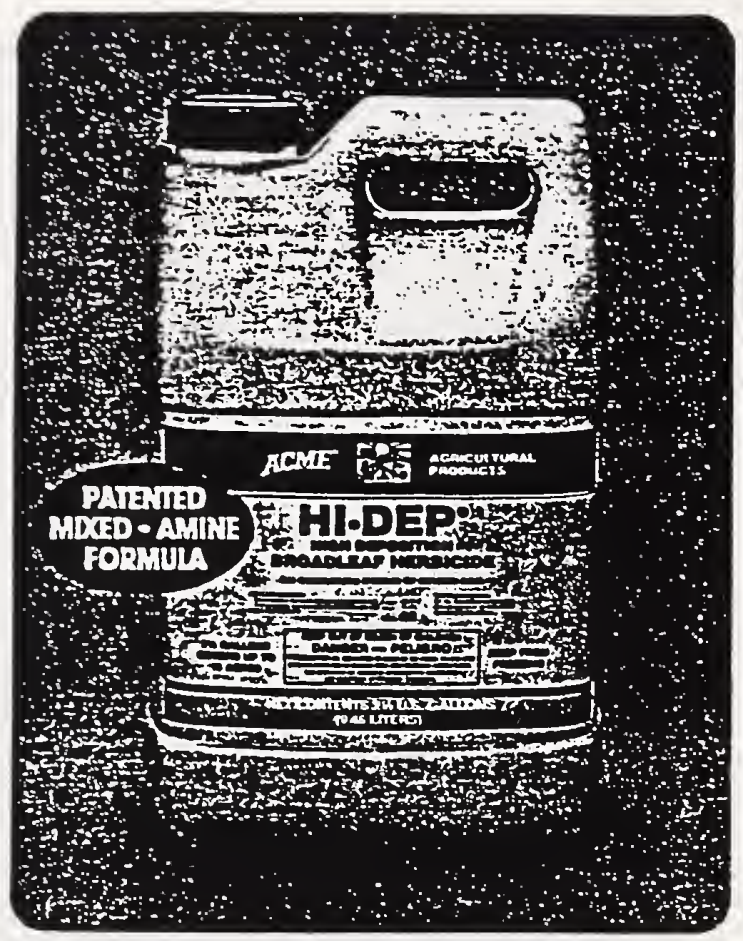

\section{NO OTHER POST-EMERGENT}

\section{DOES MORE, SO WHY PAY MORE?}

- Conada thistle, fiold blncweed and other fough broadieat perennials controlled of last including multilloro rose, buckbrush, and other woody spocies.

- Also very offective on annual broadleaf weeds. inctuding velvetleaf, cocklebur, momingglory. mustards, and ragweed. Over 120 specles Ilsted

- Apply es a low-volume sproy. proferably 5 to 10 gals. fotal solution per acre for most ground applications Aarially applled. HI-DEP noeds only enough water for a fotal sproy volume of 2 quarts mintmum por ecre.

- Droplets resist oveporation botween nozle and targot, thus remoining molst on the leof surtace for improved absorption.
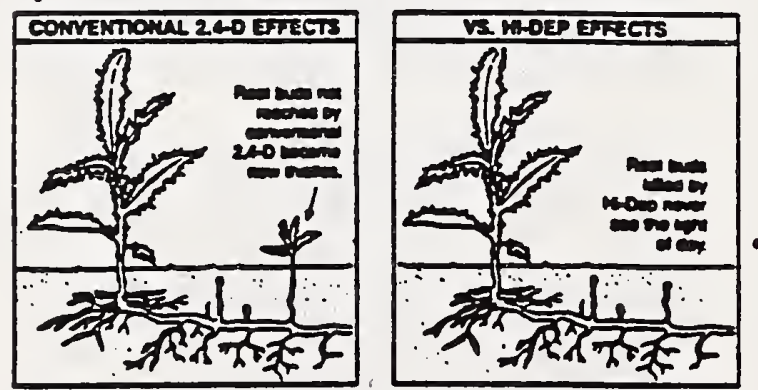

Unllke ordlnery 2A-D, more HI-DEP translocotes Into the horkontal roots, kllling the root buds.

Read label before use.

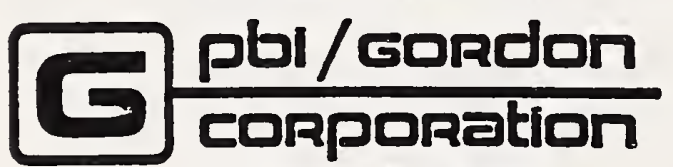

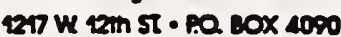

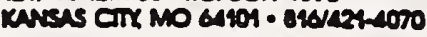

1-800-821-7925

FAx: $816-174-0162$

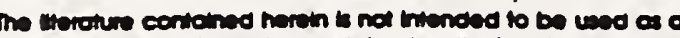

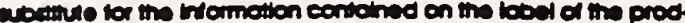

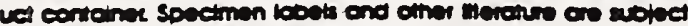
to revion selos ung the product rood and follow en bool invetion on the contaneipoctioge.

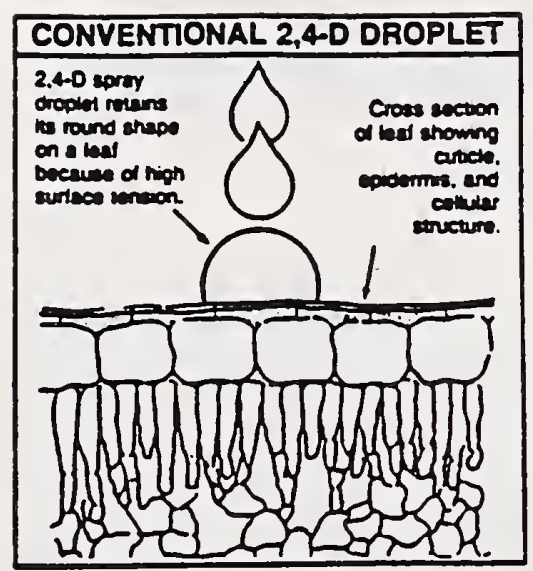

ITILE HERBICIDE PENETRATES INTO THE LEAF; MUCH EVAPORATON LOSS.

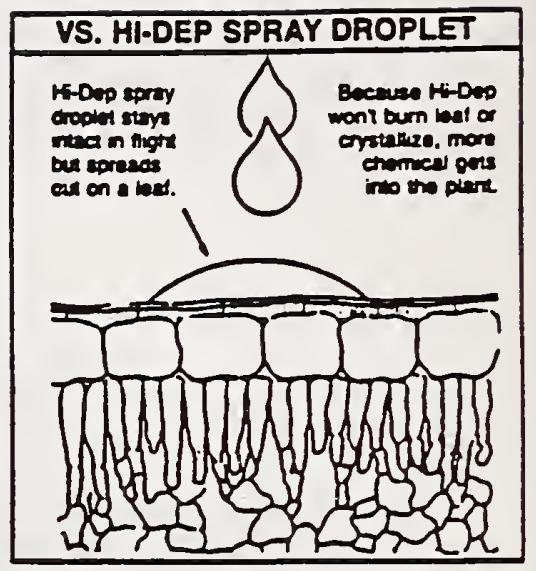

HI-DEP IS RAPIDLY AND MORE COMPLETELY ABSORBED; VERY UTTLE LOSS.

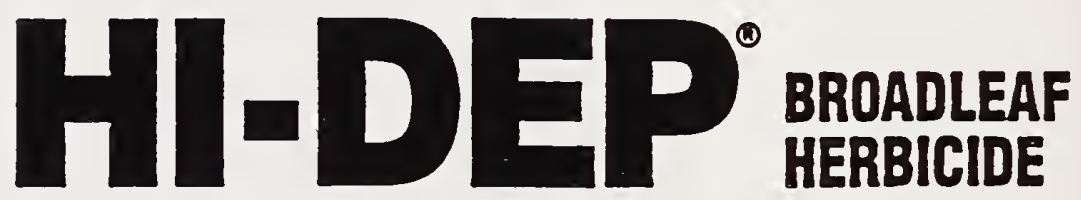

\section{CONTROLS MANY TOUGH PERENNIAL WEEDS THAT ESCAPE ORDINARY 2,4-D; ANNUALS, TOO.}

Acme HI-DEP High Depostion Low Volume Broodlea Herbicide pravides outstanding postemergence control of weeds such os Canado thistile, field blndweed and hemp dogbone which until now, hove proven very difficult if not extremely costly to control. HI-DEP overcomes the problem becouse it penetrotes deeply enough to get into the extensive root system and kills the root buds where regrowth occurs.

Contrast this to comventional 24-D treatments. While they often appear to kill the weeds and may even eliminote their competition with the crop. all too often only the tops are burned back. The same weeds and more - reappear the next growing season and year after yoar.

HI-DEP is o unique formulotion of the mbxed amine salts, dimethylamine and diethenolomine, of 24-D. combined with o special odditive which enhonces the products non-evoporotive qualities. Unlike ordinary $24-D$. when applied Hi-DEP droplets tend to resist evaporation in flight and do not crystalize. Theretore. HI-DEP is absorbed more ropldly and completely by the loot.

A radioisotope trocer study conctucted by a major midwestem univer sthy, shows thot, within four hours, over twice as much octive Ingredient will move into the roots of field binctweed then will stondard 24.D.

Becouse of HI-DEP's unique characteristics, the finished sproy wont bum the leof, even when applied stroight or in low volume solutions. Penetration is increased, even where thick or way cuticles or hairy leaf surfaces tend to leove other herbiddes high and dry. HI-DEP gets to the root of the problem - and of a cost that is little more than for ordinary 24-D!

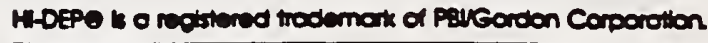

\section{RECOMMENDED USES:}

Broodleaf weed control in com, pesture, wheot and other small grains, stubble, fallow, and grain sorghum and other crops, orchards and noncrop oreos as indicoted on the label.

\section{ACINE INGREDIENTS:}

Dimethylamine salt of 24-Dichlorophenayacetic add ...............332\%

Diethonolamine salt of 24-Dlehlorophenoxyocetic acdd............ 16.3\% PACKAGING:

$2 \times 2 y_{2}$ gallon plestic contoiners per cose, shipping ................ 55 lbs. 30 gollon drum shipping weight ........................................323 lbs. 


\section{SPOT TREATMENT/NON-CROP}

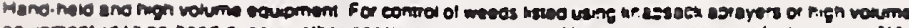

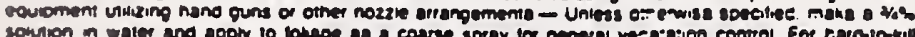

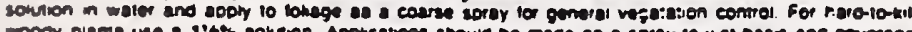

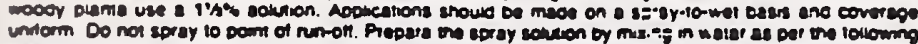
wo:

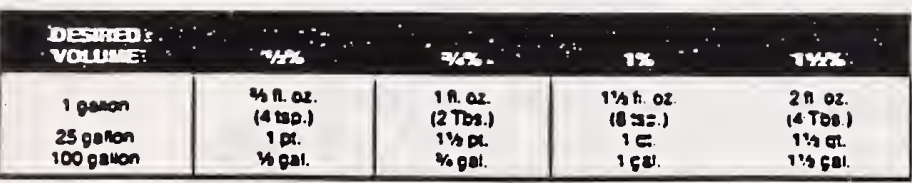

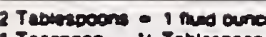

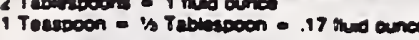

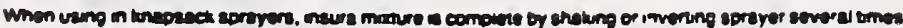

\section{CONTROL OF WOODY PLANIS OR}

BRUSH AND BROADLEAF.WEEDS OW ROADSIDES; DRAINAGE DTCHBANKS:

RIGHIS-OF-WAY; RAILROADS, FIRIEREAKS:

FORESTS (Forest SIIte Prep), FEN CE:TOWS;

INDUSTRIAL STIES \& OTHE:

SIMILAR NON-CROP AREAS:

\section{GROUNO APPLICATIONS}

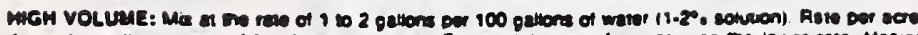

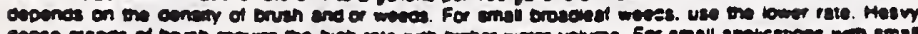

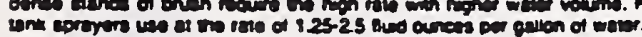

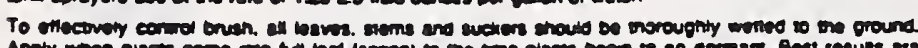

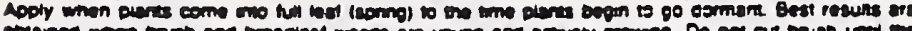

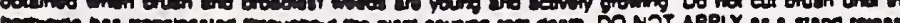

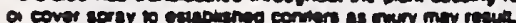

\section{AERIAL APPLICATIONS}

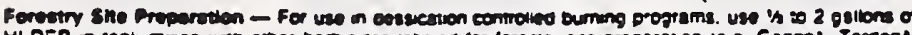

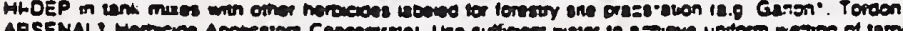

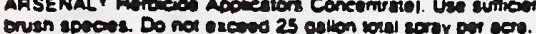

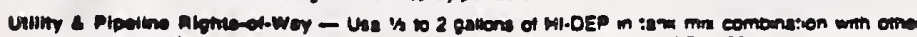

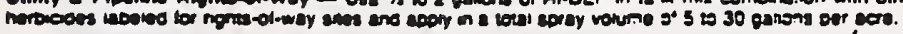

\section{TANK MIXTURES FOR}

\section{INDUSTRIALNON-CROPLAND AREAS}

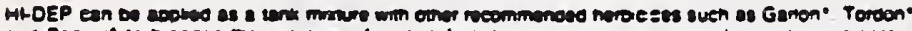

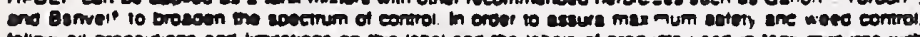

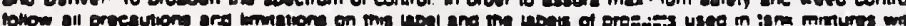

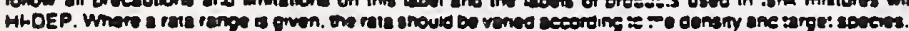

\begin{tabular}{|c|c|}
\hline Pnoovets & AATES \\
\hline MI-DEP - Ganon' $3 A$ & 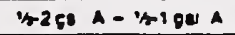 \\
\hline MLDEP - Genon' $\triangle E$ & $2+2=0.4-24 \cos A$ \\
\hline HH.OEP - Tordon' $K$ & $m-2=\Delta-1940$ or $A$ \\
\hline MI-DEP - Bannat' & $2 \cos A-10 \pi-2 \cos A$ \\
\hline
\end{tabular}

LEAFY SPURGE CONTROL IN

COLORADO, IOAHO, MINNESOTA, MONTANA, NEBRASKA, NORTH DAKOTA, SOUTH DAKOTA, WASHINGTON AND WYOMING

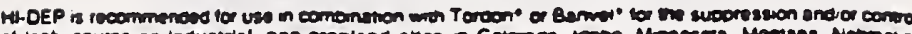

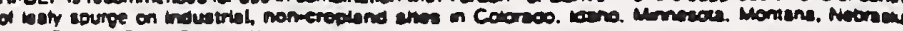

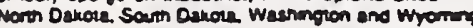

\section{HOW TO USE}

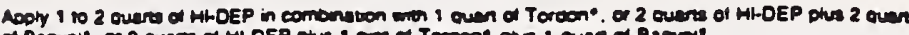

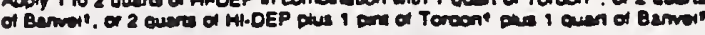

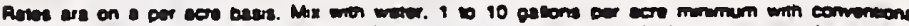

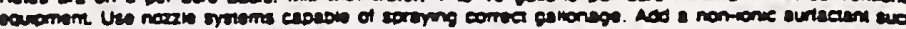

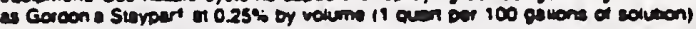

MPORTANT: BEFORE USHE HLOEP TOROON AND OA BANVEL" IN THESE COMBMATIONS. READ AND CAREFULY OBSEAVE THE CAUTIONAAY STATEMENTS AND ML OTMER INFOAN TION APPEAAING ON THE PAOOUCT LABELS.

\section{FOREST-TREE INJECTION}

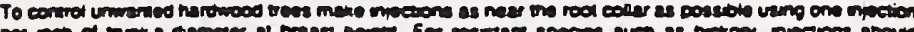

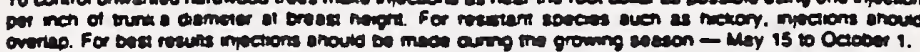

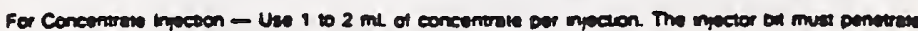
ine inner bert.

\section{LMITED WARRANTY AND DISCLAMER}

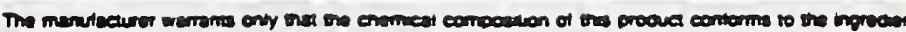
Themen on

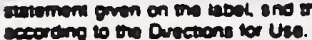

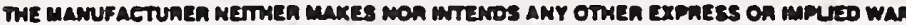

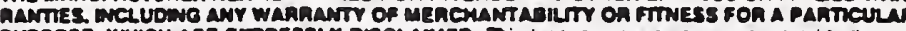

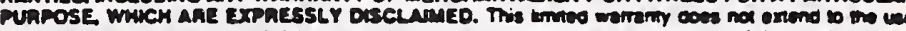

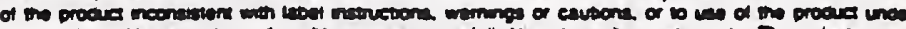

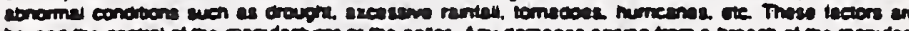

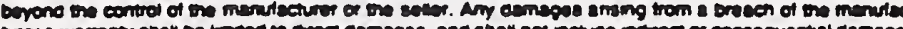

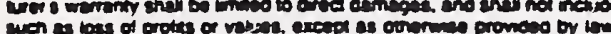

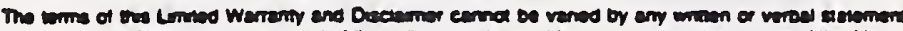

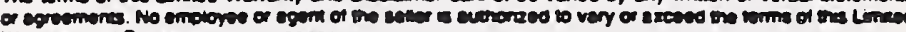
Wrenty end Deciemer in any memer.

AH-DEP 9 end STAYPAP: ere roprened trecoments of PBI GORDON CORPOPATION.

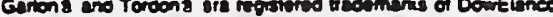

Bemene $n$ a nopreres trecemark of Semoces Crop Protection.

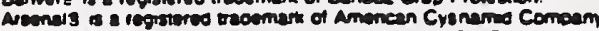

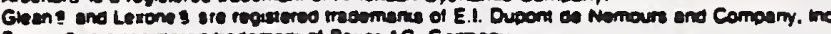

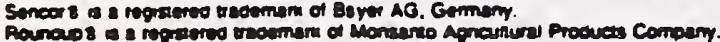

200992 AP000091

EPA REG NO. 2217.700

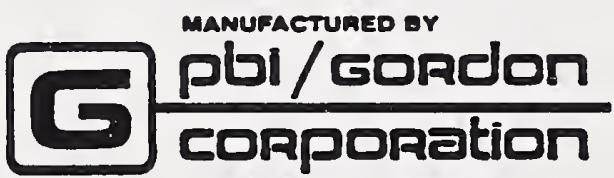

KANEAE CTr, MISBOUAI GATOT

SPECIMEN LABEL: READ CURRENT LABEL ON PRODUCT CONTAINER BEFORE USE. 


\section{Specimen Label}

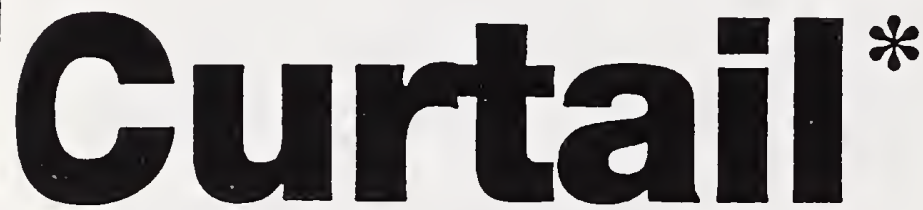

\section{Herbicide}

for Selective Control of Broadleaf Weeds in Wheat and Barley Not Underseeded with a Legume, Fallow Cropland, Grasses Grown for Seed and Conservation Reserve Program (CRP) Acres

Active Ingredient(s):

Clopyralid (3,6-Dichloro-2-pyridinecarboxylic acid) as alkanolamine salts

(of the ethanol and isopropanol series)

2.4-Dichlorophenoxyacetic Acid as alkanolamine salts

(of the ethanol and isopropanol series)

inert Ingredient(s):

Acid Equivalents:

3,6-Dichloro-2-pyridinecarboxylic acid 3.9\% - $0.38 \mathrm{lb} / \mathrm{gal}$

2,4-Dichlorophenoxyacetic acid $20.9 \%-2.0 \mathrm{lb} / \mathrm{gal}$

E.P.A. Registration No. 62719-48

EP.A. Est. 464-MI-1

\section{KEEP OUT OF REACH OF CHILDREN}

\section{DANGER}

\section{PELIGRO:}

\section{PRECAUCION AL USUARIO:}

Si usted no lee ingles, no use este producto hasta que $b$ enqueta le haya sido explicada ampliamente.

PRECAUTIONARY STATEMENTS Hazards to Humans and Domestic Animals CAUSES EYE DAMAGE AND SKIN IRRITATION - HARMFUL IF SWALLOWED

Do Not Get in Eyes, On Skin Or On Clothing - Wear Goggles Or Face Shield When Handling - When Handling This Product, Wear Chemical Resistant Gloves - Wash Thoroughly With Soap And Water After Handling - Remove Contaminated Clothing And Wash Before Reuse STATEMENTS OF PRACTICAL TREATMENT: Hin IV hush with plenty of water for at least 15 minutes. Get modical anention. If on skth, wesh with plenty of soap and water. Get medical attention if irritation persists. If swallowed, induce vomiting immediately by giving two glasses of water and sucking finger down throat. Call a physician. Do not induce vorniting or give amything by mouth to an unconscious person.
Environmental Hazards

Dritt or nunotf may adversely affect nonturget plants. Do not apply directly to water or wettands (swemps, bogs. marshes, and potholes). Do not contaminate weter when disposing of equipment wastwwaters. See edditional precautionary statements elsewhere on this label.

\section{NOTICE}

Read the entire label. Use only sccording to labed directions.

Befor buying or using this procuct, read Wherenty Disclaimer and Limitation of Remedies sections ctewhere on this label.

IN CASE OF AN EMERGENCY endangering life or property involving this product, call collect 517-636-4400 AGRICULTURAL CHEMICAL Do Not Ship or Store with Food, Feeds, Drugs, or Clothing 


\section{DIRECTIONS FOR USE}

It is a violation of Federal law to use this product in a manner inconsistent with its labeling.

Do not apply this product through amy type of irrigation system.

CURTAL Herbicide is recommended for selective, postemergence control of the following broadleaf weeds in wheat and barley not underseeded with a legume, fallow cropland (including summer fallow, post-harvest, and set-aside acres) and land in the Conservation Reserve Program (CRP). atfalfa

artichoke, Jerusalem

buckwheat, wild

bufialobur

burdock, common

chamomile, false (scentless)

chamomile, mayweed

(dogtennel)

clover, sweet

clover, red

cocklebur, common

coffeeweed

comflower (bachelor button)

dandelion

dock, curty

flixweed!

groundsel, common

hawksbeard, narrowleat

horseweed

jimsonweed

knapweed, diffuse

knapweed. Russian!

knapweed, spotted

kochia (2-4 leaf)

ladysthumb

lambsquarters, common

latuce, prickly

locoweed, white

locoweed. lambert

marshelder

mustard, tumble (Jim Hiln)

mustard, wild

nightshade, cutleat

nightshade, hairy

pennycress, field (tanweed)

pigweed, redroot

pineappleweed

plantain

radish, wild

ragweed, common

ragweed, giant

salsity, meadow (goatsbeard)

shepherdspurse

sicklepod

smarkweed, Pennsytrania

sorrel, red

sowthistle, annual

sowthistle, perennial

starthistle, yellow

sunflower, common

tansymustard, pinnate

thistle, Canada

thiste, musk

thistle, Russian (1-3 leaf

velvetleaf

vetch

volunteer beans

volunteer lentils

volunteer peas

- These weeds may only be suppressed. Suporescion is a visua rechuction in weed cempetton (rectuced poputation or noon ats compared to untreated aneas. The degree of weed control and curation of effect will vary with weed size and density, spray rate and coverage, and growing conditions betore. during and after the ume of treatment. For peremial weeds, CURTALL Herbicide witl control the nital toggrowth and ishibit regrowth ot ring the saseon of apotication (seasontong controf. A higher wee rates shown on this label, CUFTAL Herbicide may cuse a reduction in shoot regrowth in the season followng application, however, ptent response may be inconsistent dus to inherent verabibty in shoot rogrowth from perenial root systems.

Tirning: Apply to actively growing weeds. Extreme growing conditions such as drought or near freesing temperatures prior to. at and following time of apolication may reduce weod control and increase the risk of crop injury at all stages of growth. Only weeds which are emerged at the time of appliestion will be affected. Wet foliage at the time of application may decrease control. The CURTAL Herbicide treatment will be rainfast within $6-8$ hours after application.

Rate: Generally, lower labeled application rates will be satisfactory for young, succulent growth of sensitive weed species. For less sensitive species, perennials and under conditions where control is more difficutt (plant stress conditions such as drought or extreme temperatures, dense weed stands and/or larger weeds) the higher rates will be needed. Weeds in fallow or other areas where crop competution is not a factor will generaly require higher rates to obtain control or suppression.

Coverage: Adequate spray coverage and drift control are important. Obtaining a balance between spray coverage and dift control may sometimes be dificult but can be achieved. provided the applicator understands the factors affecting coverage and drift. Factors affecting spray coverage include spray volume, crop canopy and weed density. As crop canopy and weed density increase, spray volume should be increased to obtain equivalent weed control. Refer to manufacturer's recommendations for information on the relationship between gallons per acre, spray pressure, sprayer speed, nozde type and arangement, nozde height above the target canopy. droplet size and drift potential for respective application equipment. Do not apply less than 2 and not more than 40 gallons per acre total spray volume. For best resutts, apply 5 or more gallons per acre by air and 10 or more gallons per acre by ground. Reducing total spray volume may result in decreased coverage and weed control. Use enough total spray volume and a delivery system to provide thorough coverage and a unifom spray pattem. Do not apply where spray drift may be a problem due to proximity of susceptible crops or other desirable plants.

Use of Surfactanta: Addition of wetting and/or penetration agents is not usually necessary when using CURTALL Herbicide; however, if a surfactant will be added to the spray solution, use a nonionic surfactant approved for use on growing crops, such as X-77, of at least $80 \%$ active ingredient and do not exceed 4 pints per 100 gallons of spray 'solution $(0.5 \% \mathrm{v} / \mathrm{V})$. Adding a surfactant to the spray mixture may increase effectiveness on weeds but may reduce selectivity to the crop, particularty under conditions which promote plant stress.

Use With Spreyable Liquid Fertiltzer Solutions:

CUFTALL Herbicide is compatible vith most non-pressurized liquid fertilizer solutions, however, if these solutions are to be sprayed with CURTALL Herbicide, a compatibility test (jar test) should be made prior to mixing. Jar tests are particularty important when a new batch of fertilizer or pesticide is used. when water source changes, or when tank mixturs ingredients or concentrations ars changed. A compatibility test is pertormed by pouring the spray components (in the desired order and proportions) into a clear glass jar before mixing in the spray tank. Use of a compatability aid such as Unite or Compex may help obtain and maintain a unitorm spray solution during mixing and application. Agitation in the spray tank must be vigorous to compare with jar test agitation. For best resuts. liquid fertilizer rates should not exceed $50 \%$ of the total spray volume. Premix CURTAL Herbicide with water and add to the liquid fertilizerhwater mixture while agitating contents of the spray tank. Apply the spray the same day it is prepared while maintaining continuous agitation.

NOTE: Foliar-applied liquid fertilizers can cause yellowing or baf bum of crop folinge.

\section{Wheat and Barley}

Timing: Apply CURTAL Herbicide in the spring to actively growing wheat or barley once 4 leaves have untolded on the main stem and tillering has begun up to the jointing stage (first node of main stem defectable). To control or suppress weeds listed above, make application after maximum emergence of the target weeds but before they exceed 3 inches in height or diameter (for rosettes). To obthin saason-tong control of perennial weeds such as Canada thistle, apply after the majority of the weed's basal leaves have emerged from the soil, but before bud stage. A later tinning of application (when the grain is between the jointing and boot stages) may be used to treat later-emerging weeds, however, do not apply unless the risk of injury is acceptable. Do not apply after the boot stage.

NOTE: Do not permit dainy animals or meat animals being finished for slaughter to forage or graze treated grain fields within 1 week after tratment. Do not havest hay from treated grain fields.

Rate: Apply 2 to 22/s pints of CURTALL Herbicide per ecre. The higher rate may be used when the condition of the weeds and/or crop at the time of treatment may prevent optimum control.

NOTE: Hlgher rates of CUATALL Herbicide or CURTALL Horticide applications following spring postemergence treatments with 2,-D or MCPA mry increse the risik of erop injury. 


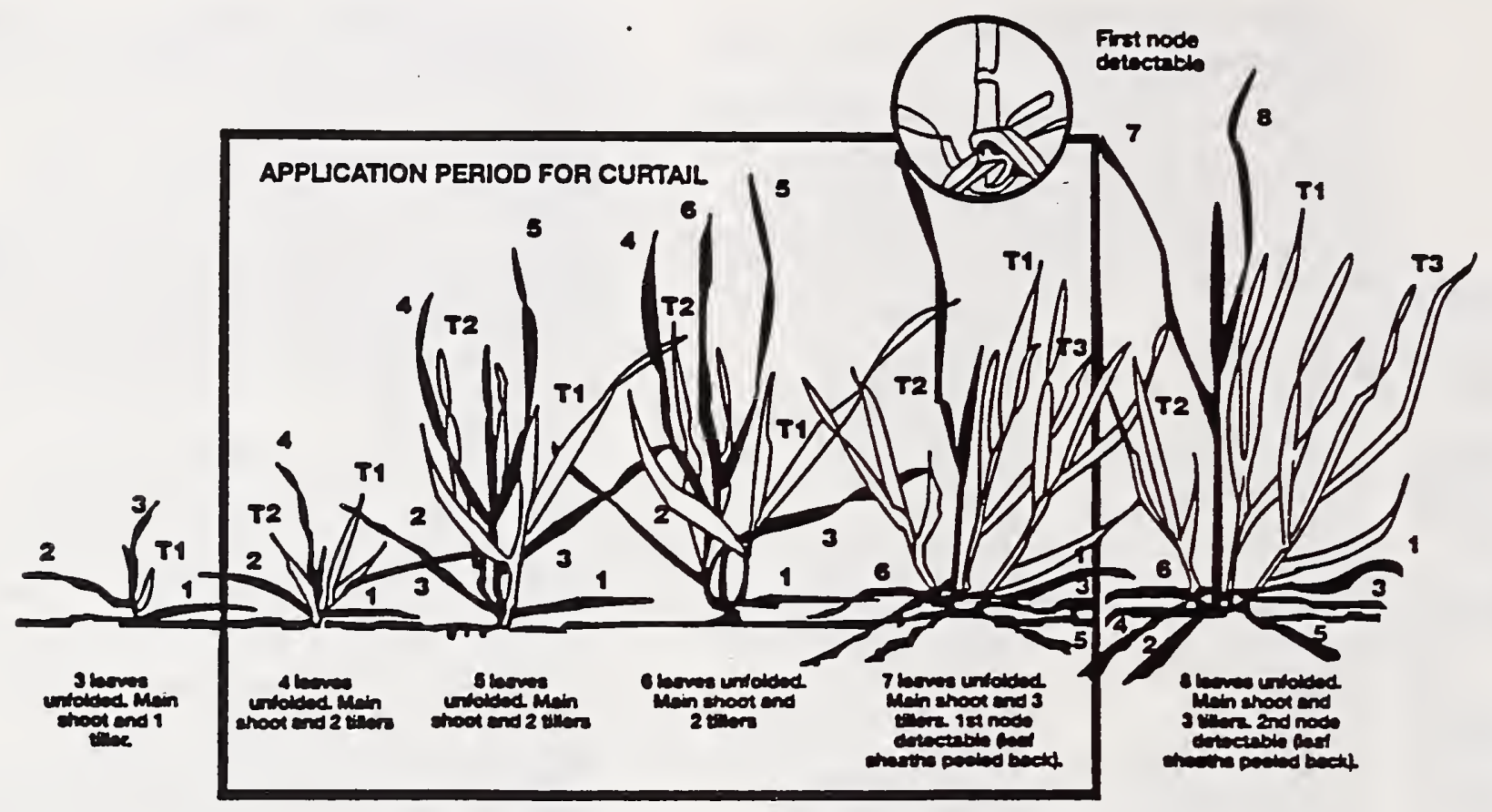

Tank Mixtures for Wheat and Barley: This product may be tank mixed with the following herbicides for control of additional weeds in wheat and barley. Read and follow the label of each tank mix product used for precautionary statements, directions for use, weeds controlled and geographic and other restrictions. When tank mixing, use in accordance with the most restrictive of label limitations and precautions. No tabel dosages should be exceeded. This product cannot be mixed with any product containing a label prohibition against such mixing.

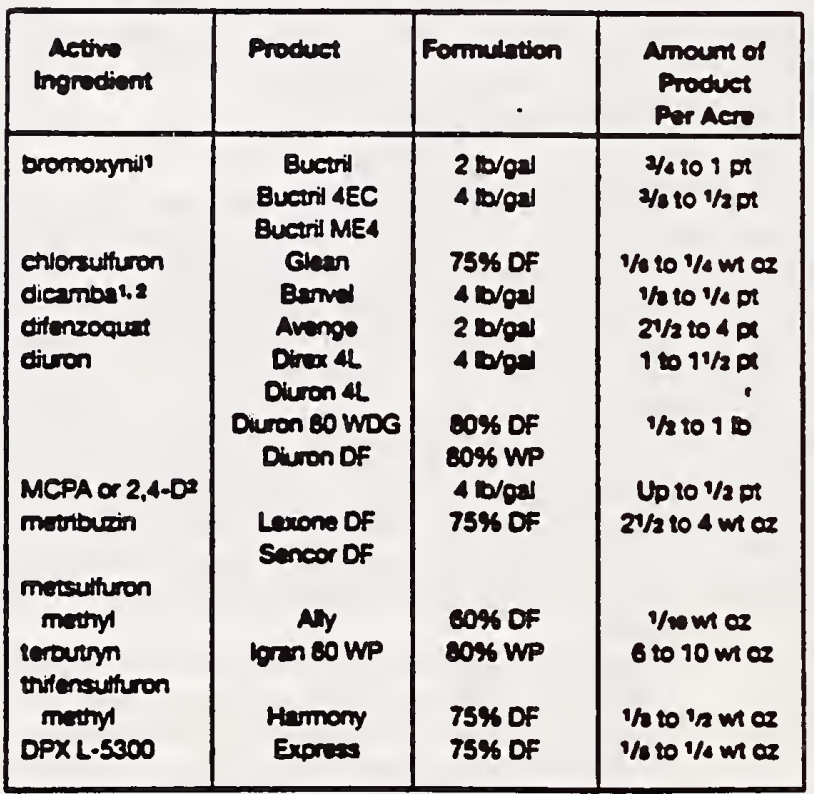

1 Buctril of Banvel tank mixes with CUFTAL Herbicide may be usetul in oroadening the amial woed control spectrm but may reduce control of perenniats, such as Cansoda thistia.

2 Note: Do not tank mix CUFTAUL Herbicide with 2,4-D o dieamba unleses the nask of crop injury is ecceptable.

\section{Fallow Cropland}

Timing: CURTAlL Herbicide can be applied either posthavest. in the spring/summer (during fallow period) or to set-aside acres to control or suppress weeds listed above (refer to rotation restrictions). Apply to young. emerged weeds under conditions that promote active growth. For best results on tough perennial woeds such as Canada thistle, apply atter the majority of the basal leaves have emerged. but before bud stage. Later applications may resutt in less consistent control. Extreme growing conditions (such as drought or near freezing temperatures) priox to, at, and following the time of application may reduce weed control.

For best results, wait 14 to 20 days after application before cultivating or fertifing with shenk-type applicators to allow for thorough transiocation. To avoid potential phytotoxicity, allow at lesst 20 days after application before seeding to wheat. barley or grasses.

Rate: Apply 4 pints of CURTALL Herbicide per acre. Use the higher rate on perennial weeds or when the condition of the weeds at the time of treatment may prevent optimum control.

Tank Mibtares For Fallow Croplendt To improve control of certain broadleaf woeds, CURTAL Herticido at 2 pints per acre may be applied with up to $1.5 \mathrm{~b}$ se per acre additional 2,4-0. When mixing, read and follow the tabel of each tank mix procuct used for precautionay statements, directions for use. weeds comtrolled and geographic and other restrictions. When tank mining, use in sccordance with the most restrictive of label Finitations and precautions, No label doses should be exceeded. This product cannot be mbxed with any product. containing a tabel pronbition apainst such mixing.

\section{Grasses Grown for Seed}

Tining: Appty anly to established grasses before the boot stage. Applications in the boot stage and beyond will resutt in increased injury, Do not epply to bentgrass unless injury can be toletated.

Rate: Use 2 to 4 pints of CURTAL Herbicide per acre tor control of annual weeds and Canada Thistle. The potental for crop injury exists duv to the 2,4-D component of this product and must be balanced against the benefits of improved weed control. Potential for crop injury increases with higher rates.

Ro-treat as necessary, but do not exceed 4 pints per acre of CURTAL per sanson. 
NOTE: Do not graze (dainy) cattle in treated areas for 14 days atter application. Remove meat animals trom treshly treated areas for 7 days before slaughter. Withdrawal is not needed if 2 weeks or more have elapsed since application. Do not cut treated grass for hay within 30 days after application.

\section{Conservation Reserve Program (CRP) For Seeding To Permanent Grasses Only}

Do not use CURTALL Herblelde if logumes or bentgrass are a desined cover during CRP.

Grass grown on CRP acres cannot be grazed or used for hay.

Conditions that stress grasses, such as drought, will increase potential for injury to the grass at all stages of growth. Do not use in newly seeded areas until grass is established.

Timing: CURTAlL Herbicide can be applied when perennial grasses have become established (tillering, with at least 1.5 inches secondary roots, and good vigor). For control of weeds such as musk thistle, Canada thistle and krapweed (ditfuse. spotted and Russian), apply to actively growing weeds after the majority of the basal leaves have emerged. but before bud stage. Later applications may result in less consistent control.

Rato: Apply 2 to 5 quarts of CURTALL Herticide per acre.

\section{USE PRECAUTIONS}

Apply only once per 12 -month period. except for grass grown for seed (see Directions For Use). A fallow treatment that preceeds or follows a small grain application is also allowed. This product can affect susceptible broadleaf plants directly through foliage and indirectly by root uptake from treated soil. Therefore, do not apply CURTAlL Herbicide directy to or allow spray drift to come in contact with vegetables, flowers. grapes. tomatoes, potatoes, beans, lentils, peas, affalfa. sunflowers, soybeans, safflower, or other desirable broadleaf crops and omamental plants or soil where these sensitive crops will be planted the same season.

Do not contaminate irrigation ditches or water used for irrigation or dornestic purposes.

Wheat, barley, oats. grasses, or sugar beets (including beets grown for seed) may be planted less than 12 months after treatment.

Afalfa, asparagus, canola, cole crops, mint, onions, safflower, and strawberries may be planted 12 months atter treatment. Dry beans, soybeans and sunflowers may also be planted at 12 months after treatment, except in soils with less than $2 \%$ organic matter receiving less than 15 inches of natural precipitation in the 12 month period following treatment. For these areas see SPECLAL CONDMONS below.

To avoid potential phytotoxicity all other crops including peas. lentils, potatoes. and broadleaf crops grown for seed should not be planted for 18 months after treatment unless the risk of injury is acceptable.

SPECLAL CONDIMONS: CURTALL residues in ptant tissues which have not completely decayed may affect succesding susceptible crops. In areas defined proviousty as low in organic matter and precipitation, sensitive crops such as dry beans, soybeans, and sunflowers may be injured when planted 12 months after treatment. Uniess the risk of injury is ecceptable, these crops should not be planted until 18 months after treatment. The potential for injury may be reduced by buming, removal, or incorporation of treated crop residues with a minimum of 2 supplemental Fall irigations.

Avoid Spray Drift Applications should be made to avoid spray drith since very small quantities of the spray, which may not be visible. may severely injure susceptible crops during both growing and dormant periods. Use coarse sprays to minimize dritt since, under adverse weather conditions, fine spray droplets may dritt a mile or more. Fine droplets can present a dritt hazard. A dritt control or deposition agent such as Nalco-Trol may be used with this product to aid in rechucing spray dritt. If used, follow all use recommendations and precautions on the product label.
Ground Appllcation: To minimize spray drift, apply CURTAIL Herbicide in a total spray volume of 10 or more galtons per acre as a large-droplet. low pressure spray. Refer to manufacturer's recommendations for additional information on gallons per acre, spray pressure, sprayer speed, nozde types and amangernents. nozde heights above the target canopy, etc., for respective application equipment. Spot treatments should only be applied with a calibrated boom to prevent misapplication. With ground equipment, spray drift can be lessened by keeping the spray boom as low as possible; by apphying no more than 20 gallons of spray per acre; by using no more than 30 pounds spraying pressure with large dropletproducing nozzle tips; by spraying when wind velocity is low: and by stopping all spraying when wind exceeds 6 to 7 miles per hour. Do not apply with hollow cone-type insecticide or other nozdes that produce a fine-droplet spray.

Aorial Application: With aircratt, dift can be lessened by applying a coarse spray, by using no more than 30 pounds spray pressure at the nozdes; by using straight-stream nozdes directed straight back; by using a spray boom no longer than $3 / 4$ the wing span of the aircraft, and by spraying only when wind velocity is less than $6 \mathrm{mph}$.

Do Not Apphy By Aireraft When An Air Temperature Inversion Exists. Such a condition is characterized by little or no wind and with lower air temperature near the ground than at higher levels. The use of a smoke device on the aircratt or continuous smoke column at or near site of application will indicate air direction and velocity, and whether a temperature inversion is present, which is shown by layering of the smoke. Do not move treated soil and avoid situations where treated soil particles may blow into areas where susceptible crops are grown. Violent windstorms may move soil particles. If this product is on soil particles and they are blown onto susceptible plants, visible symptoms may appear. Serious injury is unlikely. The hazard of movement of this product on cust is reduced if treated fields are inigated or if rain occurs shortly after application.

Straw from treated areas, or manure from animals which have grazed treated areas, cannot be used for composting or mulching on ground where susceptible crops may be grown the following season. To promote herbicide decomposition. plant material should be evenly incorporated or bumed. Do not use in a greenhouse. Excessive amounts of this herbicide in the soil may temporanily inhibit seed germination or plant growth.

Do not contaminate water when disposing of equipment wastwwaters. Apply this product only as specified on this label. Do not transfer livestock from treated grazing areas onto sensitive broadleaf crop areas without first allowing 7 days of grazing on an untreated pasture. Otherwise, urine may contain enough clopyralid to cause injury to sensitive broadleaf plants. Mixing and Losding: Most cases of groundwater contamination involving phenoxy herbicides such as 2,4-D have been associated with mixinghoading and disposal sites. Caution should be exercised when handling 2,4-D pesticides at such sites to provent contamination of groundwater supplies. Use of closed systems for mixing or transferring this pesticide will reduce the probability of spills. Placement of the mixingloading equipment on an impervious pad to contain spills will help provent groundwater contamination. 


\section{PRECAUTIONARY STATEMENTS Environmental Hazards}

Clopyralid is a chemical which can travel (seep or leach) through soil and under certain conditions contaminate groundwater which may be used for irrigation or drinking purposes. Users are advised not to apply clopyralid where soils have a rapid to very rapid permeability throughout the profile (such as loamy sand to sand) and the water table of an undertying aquifer is shallow, or to soils containing sinkholes over limestone bedrock, severely fractured surfaces, and substrates which would allow direct introduction into an aquifer. Your becal agricultural agencies can provide further information on the type of soil in your area and the location of groundwater.

\section{STORAGE AND DISPOSAL}

Do not contaminate water, food or feed by storage or disposal. Storage: Store above $10^{\circ} \mathrm{F}$ or warm and agitate betore use. Pesticide Disposat: Pesticide wastes are toxic. Improper disposal of excess pesticide, spray mixture, or rinsate, is a violation of Federal Law and may contaminate groundwater. If these wastes cannot be disposed of by use according to label instructions, contact your State Pesticide or Envionmental Control Agency, or the Hazardous Waste representative at the nearest EPA Regional Office for guidance.

Container Disposal (Metan): Do not rouse contuinar.Triple rinse (or equivalent). Puncture and dispose of in a sanitary landfill, or by other procedures approved by state and local authonities.

Contoiner Disposal (Plastic): Do not reuse container. Triple rinse (or equivalent). Puncture and dispose of in a sanitary landfill, or by incineration, $\alpha$, if allowed by state and local authorities. by buming. If bumed, stay out of smoke.

Generat: Consutt federal, state, or local disposal authorities for approved attemative procedures.

Be sure that use of this product conforms to afl application regulations.

\section{WARRANTY DISCLAIMER}

DowElanco warrants that this product conforms to the chernical description on the label and is reasonably if for the purposes stated on the label when used in strict accordance with the directions, subject to the inherent risks set forth below. DOWEL ANCO MAKES NO OTHER EXPRESS OR IMPUED WARRANTY OF MERCHANTABIUTY OR FITNESS FOR A PARTICULAR PURPOSE OR AYY OTHER EXPRESS OR IMPUED WARAANT

\section{INHERENT RISKS OF USE}

It is impossible to eliminate all risks associated with use of this product. Crop injury, lack of pertormance, or other unintended consequences may result because of such factors as use of the product contray to label instructions (inctuding conditions noted on the label, such as unfavorable temperctures, soil conditions, etc.), abnomal conditions (such as excessive rainfall, drought, tomadoes, hurricanes), presence of other materials, the manner of application, or other factors, all of Which are beyond the control of Dowelanco or the seller. AII such risks shall be assumed by Buyer.

\section{LIMITATION OF REMEDIES}

The exctusive remedy for losses or damages resulting from this product (inctuding claims based on contrect, negligence, strict liability, or other legal theories), shall be limited to, at DowElanco's election, one of the following:

(1) Refund of purchase price paid by buyer or user for product bought, or

(2) Replacernent of amount of product used.

Dowelanco shall not be liable for losses or damages resulting from handling or use of this proctuct unless Dowelanco is promptly notified of such loss or damage in witing. In no case shall Dowelanco be liable for consequential or incidental damages or losses.

The terms of the Warranty Disctaimer above and this Limitation of Remedies cannot be varied by any written or verbal statements or agreements. No employee or sales agent of DowElanco or the seller is authorized to vary or exceed the terms of the Warranty Disclaimer or this Limitation of Remedies in any manner.

08103-L1

\section{DowElanco}

Indianapolis, tndiana 46268 U.S.A.

- Trademark of Dowelanco 


\section{Specimen Label}
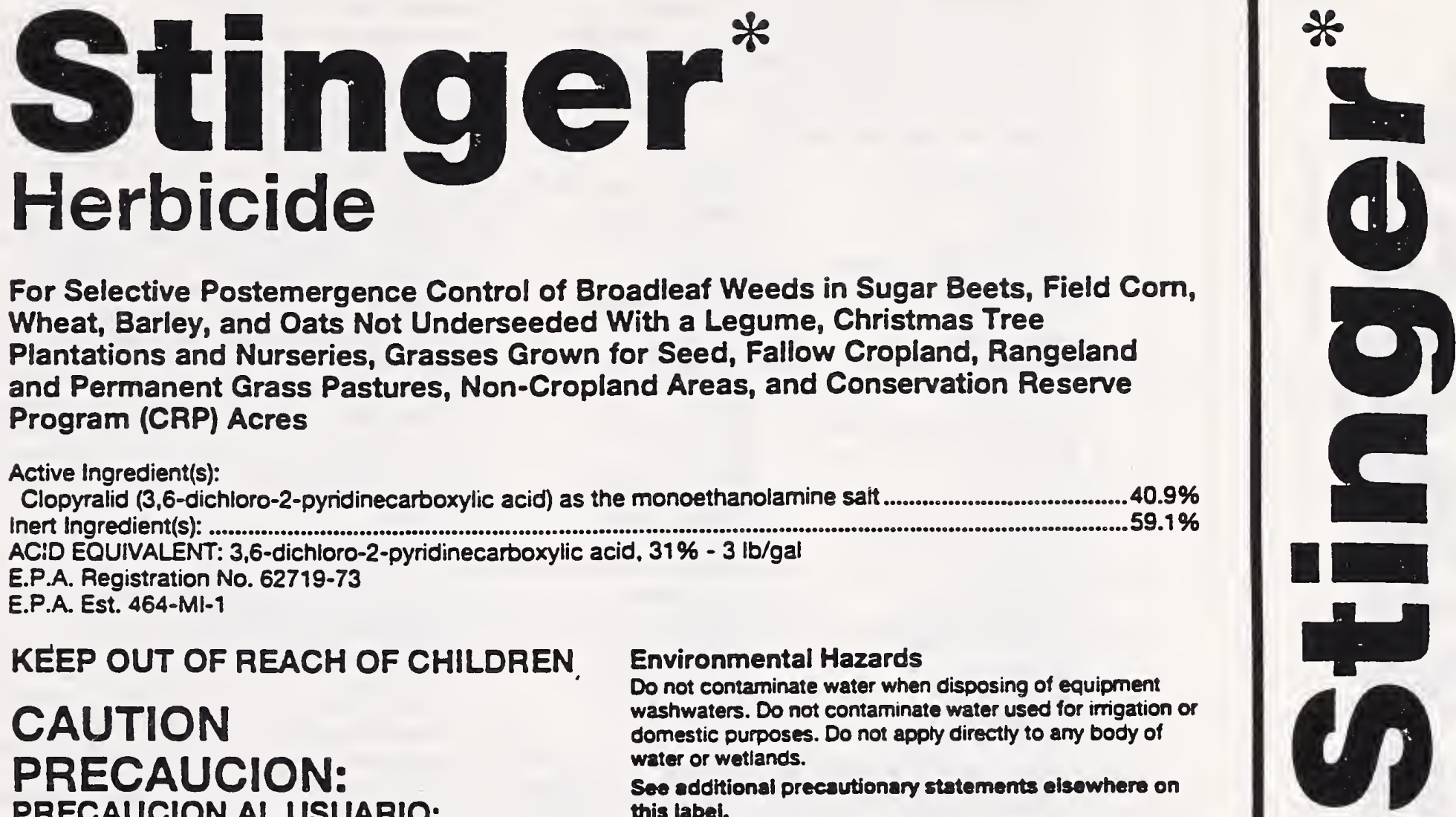

For Selective Postemergence Control of Broadleaf Weeds in Sugar Beets, Field Com, Wheat, Barley, and Oats Not Underseeded With a Legume, Christmas Tree Plantations and Nurseries, Grasses Grown for Seed, Fallow Cropland, Rangeland and Permanent Grass Pastures, Non-Cropland Areas, and Conservation Reserve Program (CRP) Acres

Active Ingredient(s):

Clopyralid (3,6-dichloro-2-pyridinecarboxylic acid) as the monoethanolamine sait.

inert Ingredient(s):

ACID EQUIVALENT: 3,6-dichloro-2-pyridinecarboxylic acid, $31 \%-3 \mathrm{lb} / \mathrm{gal}$

E.P.A. Registration No. $62719-73$

E.P.A. Est. 464-MI-1

\section{KEEP OUT OF REACH OF CHILDREN}

\section{CAUTION \\ PRECAUCION:}

PRECAUCION AL USUARIO:

Si usted no lee ingles. no use este producto hasta que la etiqueta le haya sido explicada ampliamente.

\section{PRECAUTIONARY STATEMENTS}

Hazards to Humans and Domestic Animals CAUSES EYE INJURY • HARMFUL IF INHALED OR ABSORBED THROUGH SKIN

Avoid Contact With Eyes, Skin Or Clothing

- Avoid Breathing Spray Mist - Wash

Thoroughly With Soap And Water After

Handling - Remove Contaminated

Clothing And Wash Before Reuse

STATEMENTS OF PRACTICAL TAEATMENT: $i$ in eYes, flush with plenty of water. Get medical aftention if irritation persists. If on skin, wash with plenty of soap and water.

Get medical attention.

Physical or Chemical Hazards

COMBUSTIBLE - Do Not Use or Store Near Heat or Open Flame. Do Not Cut or Weld

Container.

\section{Environmental Hazards}

Do not contaminate water when disposing of equipment washwaters. Do not contaminate water used for irrigation of domestic purposes. Do not apply directly to any body of water or wetlands.

See additional precautionary statements elsowhere on this label.

\section{NOTICE}

Read and understand the entire label bejore using. Use only aceording to label directions.

Before buying or using this product, read WARRANTY UMITATIONS AND DISCLAIMER ${ }^{\circ}$ elsewhere on this label. If terms are not acceptable, retum unopened package at once to seller for full refund of purchase price paid. Otherwise, use by the buyer or any other user constitutes scceptance of the terms under WARRANTY LIMITATIONS AND DISCLAMER.

\section{IN CASE OF AN EMERGENCY}

endangering life or property involving this product, call collect 517-636-4400

AGRICULTURAL CHEMICAL

Do Not Ship or Store with Food, Feeds, Drugs, or Clothing 


\section{DIRECTIONS FOR USE}

It is a violation of Federal law to use this product in a manner inconsistent with its labeling.

Do not apply this product through amy type of irrigation system.

STINGER Herbicide is recommended for selective. postemergence control of the following broadleaf weeds in sugar beets, field com, wheat, barley, and oats not underseeded with a legume, fallow cropland, rangeland and permanent grass pastures, grasses grown for seed.

Christmas trees, conservation reserve program (CRP) acres, and non-cropland areas including fence rows, around farm buildings, and equipment pathways.

artichoke, Jerusalem

marshelder

buckwheat, wild

butfalobur'

burdock, common

chamomile, false (scentless)

chamomile, mayweed

(dogienne)

clover, sweet

clover, red

cocklebur, common

cotfeeweed

comflower (bachelor button)

dandelion

dock, curty

groundsel, common

hawksbeard, narrowleat

horseweed

jimsonweed

knapweed, dithuse

knapweed, Russian '

knapweed, spotted

ladysthumb'

lettuce, prickly

locoweed, white

locoweed, lambert

- These weeds may only be suppressed. Suppression is a visua reduction in wed competition (reduced population or vigor) as compared to umreated areas. The degree of weed control and ourction of effect will vary with weed size and density. spray rate and coverne, and growing conditions belore. duning, and atter the time of treatmem. For penennial weds, STINGER Herbieide will control the initial toporowth and inhibit regrowth during the season of application (season-long controf). At higher use rexes shown on this labet. STINGER Herbicide may cause a reduction in shoot regrount in the seseon following oplication: howrver, plam response may be inconsistem due to inherem variability in shoof reprowth from peremial root systems.

Timing: Apply to actively growing weeds. Extreme growing conditions such as drought or near freezing temperatures prior to, at, and following time of application may reduce weed control and increase the risk of crop injuny at all stages of growth. Onty weeds which are emeroed et the time of application will be affected. Wet .oliage at the time of application may decrease control. The treatment with STINGER Herblcide will be rainfast within $6-8$ hours atter application.
Rate: Generally, lower labeled application rates will be satisfactory for young, succulent growth of sensitive weed species. For less sensitive species, perennials, and under conditions where control is more difficult colant stress conditions such as drought or extreme temperatures, dense weed stands, and/or larger weeds), the higher rates will be needed. Weeds in fallow or other areas where crop competition is not a factor will generally require higher rates to obtain control or suppression.

Coverage: Adequate spray coverege and difft control are important. Obtaining a balance between spray coverage and drift control may sometimes be difficult but can be achleved provided the applicator understands the factors affecting coverage and drift. Factors affecting spray coverage include spray volume, crop canopy, and weed density. As crop canopy and weed density increase, spray volume should be increased to obtain equivalent weed control. Refer to manufacturer's recommendations for information on the relationship between gallons per acre. spray pressure, sprayer speed, nozje type and arrangement, noale height above the target canopy. droplet size, and dift potential for respective application equipment. Use equipment and nozje types which are designed for herbicide application. Do not apply less than 2 and not more than 40 gallons per acre total spray volume. For best results, apply 5 or more gallons per acre by air and 10 or more gallons per acre by ground. Reducing total spray volume may result in decreased coverage and weed control. Use enough total spray volume and a delivery system to provide thorough coverege and a uniform spray pattem. Do not apply where spray ditt may be a problem due to proximity of susceptible crops or other desirable plants. Use of Adjuremts: Addition of surfactants, crop oils, or other adjuvants is not usually necessary when using STINGER Herbicide. Adding a surfactant to the spray mixture may increase effectiveness on weeds but may reduce selectivity to the crop, particulaty under conditions which promote plant stress. $f$ an adjurant is added to the spray solution, follow all manufacturer use guidelines.

Tank Mixes: When tank mixing, read and follow the label of each tank-mix product used for precautionary statements. directions for use, meeds controlled, and geographic and other restrictions. Use in sccordance with the most restrictive of label limitations and precautions. No label dosages should be exceeded. This product cannot be mixed with amy product containing a label prohibition against such mixing. 
WEED CONTROL GUIDELINES ?

Amount of STINGER Per Acre X Use Site 2

\begin{tabular}{|c|c|c|c|c|c|c|c|}
\hline $\begin{array}{l}\text { Weed } \\
\text { Species }\end{array}$ & $\begin{array}{l}\text { Growth } \\
\text { Stage }\end{array}$ & $\begin{array}{c}\text { Sugar Beet, } \\
\text { Christmas Trees }\end{array}$ & $\begin{array}{l}\text { Wheat, } \\
\text { Esriey, Oats }\end{array}$ & $\begin{array}{l}\text { Grasses } \\
\text { For Seed }\end{array}$ & $\begin{array}{l}\text { Faliow, } \\
\text { Non-Crop }\end{array}$ & $\begin{array}{c}\text { Range : } \\
\text { Pasture, CAP }\end{array}$ & $\begin{array}{l}\text { Flold } \\
\text { Com }\end{array}$ \\
\hline $\begin{array}{l}\text { clover } \\
\text { cocklebur } \\
\text { sunflower } \\
\text { ragweeds } \\
\text { jimsonweed } \\
\text { volunteer } \\
\text { soybean } \\
\text { vetch } \\
\text { marshelder }\end{array}$ & Up to 5 leaf & $1 / 4-1 / 2 p t$ & $1 / 4-1 / 2 p t$ & $1 / 4-1 / 2 p t$ & $1 / 4-1 / 2 p t$ & $H$ - H pt & $1 / 4 \cdot 1 / 2 p t$ \\
\hline $\begin{array}{l}\text { wild } \\
\text { buckwheat } \\
\text { nightshade sp. } \\
\text { buffalobur } \\
\text { smartweeds } \\
\text { (suppression) }\end{array}$ & $\begin{array}{c}1-3 \text { leaf stage, but } \\
\text { before vining } \\
2-4 \text { leal } \\
2-3 \text { leal }\end{array}$ & $1 / 2 p t$ & & & & & \\
\hline $\begin{array}{l}\text { Canada thistle } \\
\text { sowthistle } \\
\text { (suppression) } \\
\text { knapweeds, } \\
\text { spotted/dithuse } \\
\text { knapweeds, } \\
\text { Russian } \\
\text { (suppression) }\end{array}$ & $\begin{array}{l}\text { rosette to prebud } \\
\text { up to bud stage }\end{array}$ & $\begin{array}{l}1 / 2 \cdot 4 / p t \\
\text { p pt } \\
\text {. }\end{array}$ & $1 / 4 \cdot 1 / 2 p t$ & $\begin{array}{l}x-4 t p t \\
y-1 p t\end{array}$ & - & $\begin{array}{l}y-1 p t \\
y-1 p t \\
1-1 \% p t\end{array}$ & - \\
\hline
\end{tabular}

'This table is imended as a reference onty. For complete instructions see the body of the text.

2 Use the lower rate for light to moderate infestations and good growing conditions and tha nigher rate for dense infestations or under poor growing conditions such as drought.

\section{Sugar Beets}

STINGER Herbicide is recommended for the control of various annual and perennial broadieaf weeds infesting sugar beets. Apply $\%$ to $/ 2$ pint of STINGER Herbicide per acre with ground equipment as a broadcast foliar spray. Apply in 10 or more gallons total spray volume per acre when the sugar beets are in the cotyledonto 8 leat stage of growth and the weeds are young and actively growing. Re-treat as necessary but do not exceed /s pint of STINGER Herbicide per acre per season. Do not apply within 105 days before harvest of beet roots and tops. Do not apply to sugar beets grown for seed.

STINGER Herticide may be applied as a band treatment. Use the formulas below to determine the appropriate rate and volume per treated acre.

Band width

$\frac{\text { in inches }}{\text { Row width }} \times \begin{aligned} & \text { Broadeast rate } \\ & \text { per treated acre }\end{aligned}=\begin{aligned} & \text { Band rate } \\ & \text { per treated acre }\end{aligned}$

in inches

Band width

in inches

Broadeast volume Band volume

Row with $X$ per treated acre $=$ per treated acre in inches

For annual weed control spray $\%$ - $1 / 2$ pt of STINGER Herbicide per acre on weeds up to the 5 leal growth stage. Wild buckwheat applications should bo made at the 1-3 leaf stage, before vining begins.

For the most effective control of perennials such as Canada thistle and sownistle, apply $1 / 2$ - $/ 2$ pint of STINGER Herbicide per acre as a broadcast treatment to the entire infested area. Apply when the majority of basal leaves have emerged, but before the bud stage. Cultivation can disnpt transiocation to the roots of perennials such as Canada thistle. For best results do not cultivate thistle patches.
To promote herbicide efficacy wait a minimum of 7 days after application before flood or furrow irrigation.

Tenk Mixes: To control additional broadieaf weeds and provide consistent control of difficult weeds such as wild buckwheat, tank mix $1 / 4$ - is pint of STINGER Herticide per acre with 2-6.5 pints of Betamix or Betanex. For best results, apply $\%$ pint of STINGER tank mixed with 2-6.5 pints of Betamix or Betanex followed 1-2 weeks later by a second application of $1 / 4$ - $1 / \mathrm{p}$ pint of STINGER per acre tank mixed with Betamix or Betanex. Note: Do not add additional adjuvants when employing a Betamix or Betanex tank mix with STINGER Herbicide due to increased potential for crop injury. (See tank mix section under Directions for Use.)

STINGER Herbleide may be tank mixed with grass herbicides such as Poast for grassy weed control. Be sure to include crop oil or Dash surfactant to optimize grass weed control. (See tank mix section under Directions for Use.)

\section{Field Corn}

STINGER Herbicide is recommended for postemergence control of Canada thistie. Jenusalem artichoke, annual sowthistle, common sunflower, common cocklebur, giant and common ragweed, jimsonweed and other broadieaf woods infesting field com. Apply STINGER Herbicide at suggested timing and rates for field com as indicated below.

Apply STINGER Herbieide to actively growing broadleat woeds any sime after com emergence through 24 inch tall com. Apply with ground equipment as a postemergence brosdcast or directed spray in 10 or more gallons of spray volume per acre to ensure uniform and thorough spray coverage of the weed foliage. Use onty spray nozzles designed for herbicide application. The use of flat fan noezles provides the best coverage and distribution of chemical on the plant folisge. Use spray pressures (at the boom) which nozzle manufacturers recommend to obtain desired spray volume. Use higher spray pressures and volumes when weed foliage is dense. 
For the most effective control of Canada thistle, apply is to is pint of STINGER Herbicide per acre is a broadcast treatment to the entire infested area. Apply when the majority of the basal leaves have emerged, thistles are at least 4 inches in diameter or height, but before bud stage. Use the higher rate listed for dense patches or when greater residual control is desired. Cultivation can disrupt translocation to the roots of Canada thistle. For best results, do not cultivate prior to application, and wait 14 to 20 days after application before cultivating to allow for thorough translocation.

For control of common cocklebur, giant ragweed, common ragweed, sunflower, other annual weeds and Jerusalem artichoke, apply $1 / 4$ to $1 / 2$ pint of STINGER Herbicide on woeds up to the 5 leat stage.

Hand-Held Sprayers - Applications should be made on a spray-to-wet basis with spray coverage uniform and complete. Do not spray to the point of runoff. Prepare the desired volume of spray solution by mixing the amount of STINGER Herbicide with water as shown in the following table.

\begin{tabular}{|c|c|}
\hline $\begin{array}{l}\text { Desired Volume } \\
\text { Spray Solution }\end{array}$ & $\begin{array}{l}\text { Amount of } \\
\text { STINGER }\end{array}$ \\
\hline $\begin{array}{c}1 \text { galion } \\
25 \text { gallons } \\
100 \text { gallons }\end{array}$ & $\begin{array}{l}1 / 4 \text { f. ounce } \\
1 / \text { pint } \\
1 \% \text { pints }\end{array}$ \\
\hline
\end{tabular}

Restrictions: Re-treat as necessay, but do not apply more than is pint of STINGER Herbicide per acre per year. Do not apply to field com greater than 24 inches tall. Do not allow livestock to graze treated areas or harvest treated com silage as feed within $\mathbf{4 0}$ days after last treatment.

\section{Christmas Tree Plantations And. Nurseries}

TIming: STINGER Herbicide can be safely applied over the top of actively growing: balsam fir, blue spnuce, Douglas fir, Fraser fir, grand fir, lodgepole pine, noble fir, ponderosa pine, Scotch pine, and white pine. For the Pacific Northwest: do not apply in the first year of transplanting. Apply only to trees transplanted at least one year. (Some needle curling has been observed on 1st year transplants.) Apply to actively growing weeds. For control of annual weeds apply STINGER Herbicide up to the 5 leaf growth stage (for wild buckwheat application at 3-5 leaf, but before vining, is recommended). For control of weeds such as Canada thistle and knapweeds, apply atter the majority of the basal leaves have emerged, but before bud stage. Later application may result in less consistent control.

Rate: Apply $1 / 4-1 / 2$ pint of STINGER Herbicide per acre for control of annual weeds. Apply $1 / 2-4 / 2$ pint of STINGER Herbicide per acre for difficult to control weeds such as Canada thistle and knapweeds. Appty as a broadcast or band application in a minimum of 10 gallons per acre by ground application. Use the formula under "sugar beets" to determine the appropriate rate and volume per treated acre. Apply as often as nooded. but do not exceed is pint per acre. Do not exceed $1 / 2$ pint per acre for blue spruce. Tree injury may occur with the addition of a surfactant or crop oil with STINGER Herbidde. Do not use unless previous experience shows injury is tolerable.

\section{Grasses Grown For Seed}

Timing: Apply only to established grasses before the boot stage. Applications in the boot stage and beyond can result in increased injury. Do not apply to bentgrass unless injury can be tolerated.

Rate: Use $1 / 4$ to $/ 3$ pint of STINGER Herbicide per acre for control of annual weeds and Canada thistle. Re-treat as necessary, but do not exceed is pint of STINGER per acre per season.

\section{Fallow Cropland}

TIring: STINGER Herticide can be applied either postharvest, in the spring/summer (during fallow period). or to set-aside acres to control or suppress weeds listed above (refer to rotation restrictions). Apply to young. emerged weeds under conditions that premote active growth. For best results on perennial weeds such as Canada thistle, apply after the majority of the basal leaves have emerged, but before bud stages. Later applications may result in less consistent control. Extreme growing conditions (such as drought or nase freezing temperatures) prior to, at and following the time of application may reduce weed control.

For best results, wait 14 to 20 days after application before cultivating or fertilizing with shank-type applicators to allow for thorough translocation.

Rate: Apply $1 / 4$ to $\mathrm{h}$ pint of STINGER Herticide per acre. Use the higher rate on perennial weeds or when the condition of the woods at the time of treatment may prevent optimum control.

Tank Mixtures for Fallow Cropland: To improve control of certain broadleaf weeds, STINGER Herbicide may be applied with 0.5-2.0 Ib ae per acre 2,4-0.

\section{Non-Cropland}

For use on non-cropland areas such as fencerows. around fam buildings and equipment pathways. For control of broadleaf weeds, apply $1 / 4$ to $1 \mathrm{~h}$ pints of STINGER Herticide per acre. The lower rate of $\%$ pint per acre provides acceptable control of weeds only under highty favorable growing conditions and when plants are 1.3 inches tall. Apply $1 / 2$ pint per acre when weeds are 3 to 6 inches tall or under dry conditions. Where Canada thistte or knapweeds are the primary pest, best resutts are obtained by applying 42 to $11 \%$ pints of STINGER Herbicide per acre. To improve spectrum of activity or to increase activity against taller woods. STINGER may be tank mixed with 0.5 to 2.0 lbs. ae per sere of $2,4-0$ amine or low volatile ester.

\section{Wheat, Barley And Oats}

Apply $1 / 4$ to $1 / 2$ pint of STINGER Herticide per acre from the 3 loaf stage up to earty boot stage of growth. For control of perennial woeds such as Canada thistle, $1 / 2$ pint of STINGER Herbicide per acre should be used. Russian knapweed will only be suppressed at this rate.

NOTE: Do not permit dain animals or meat animals being finished for slaughter to forage or oraze treated grain fields within 1 week after treatment. Do not havest hay from treated gran fields. 


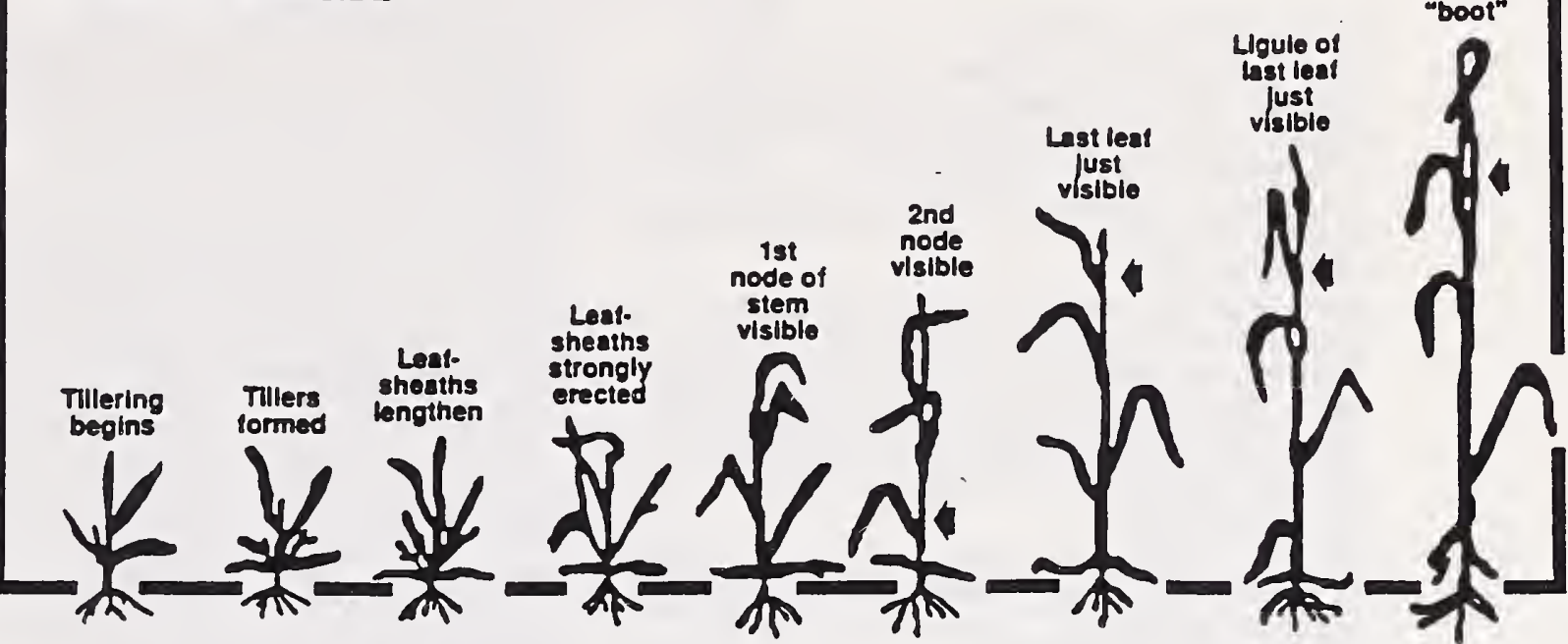

Tank Mixtures for Wheat, Barley and Oats: Tank mix $1 / 4$ to $1 / 3$ pint per acre of STINGER Herbicide with the herbicides listed below for the control of additional weeds.

\begin{tabular}{|c|c|c|c|}
\hline $\begin{array}{c}\text { Active } \\
\text { Ingredient }\end{array}$ & Product & Formulation & $\begin{array}{l}\text { Amount of Product } \\
\text { Per Acre }\end{array}$ \\
\hline bromoxynil & $\begin{array}{c}\text { Buctril } \\
\text { Buctril 4EC } \\
\text { Buctril ME4 }\end{array}$ & $\begin{array}{l}2 \mathrm{lb} / \mathrm{gal} \\
4 \mathrm{lb} / \mathrm{gal}\end{array}$ & $\begin{array}{l}\psi_{/ 4} \text { to } 1 \mathrm{pt} \\
\psi_{\mathrm{s}} \text { to } \% \mathrm{pt}\end{array}$ \\
\hline $\begin{array}{l}\text { chlorsutfuron } \\
\text { dicamba } \\
\text { diuron }\end{array}$ & $\begin{array}{c}\text { Glean } \\
\text { Banvel } \\
\text { Direx 4L } \\
\text { Diuron 4L }\end{array}$ & $\begin{array}{l}75 \% \text { DF } \\
4 \mathrm{lb} / \mathrm{gal} \\
4 \mathrm{lb} / \mathrm{gal}\end{array}$ & $\begin{array}{l}\% \text { to } 1 / 4 w \text { oz } \\
\% \text { to } \% \mathrm{pt} \\
\% / 4 \text { to } 1 \% \mathrm{pt}\end{array}$ \\
\hline & $\begin{array}{l}\text { Diuron } 80 \text { WDG . } \\
\text { Diuron DF }\end{array}$ & $\begin{array}{l}80 \% \text { DF } \\
80 \% \text { WP }\end{array}$ & $1 / 2$ to $1 \mathrm{lb}$ \\
\hline $\begin{array}{l}\text { MCPA or 2,4-D } \\
\text { metribuzin }\end{array}$ & $\begin{array}{l}\text { Lexone DF } \\
\text { Sencor DF }\end{array}$ & $\begin{array}{l}4 \mathrm{lb} / \mathrm{gal} \\
75 \% \mathrm{DG}\end{array}$ & $\begin{array}{c}1 / 2 \text { to } 1 \mathrm{pt} \\
2 \% \text { to } 4 \mathrm{wt} \text { or }\end{array}$ \\
\hline $\begin{array}{l}\text { metsulfuron } \\
\text { methyl } \\
\text { terbutiyn } \\
\text { thiameturon }\end{array}$ & $\begin{array}{l}\text { Aly } \\
\text { Igran 80WP } \\
\text { Hamony } \\
\text { Express }\end{array}$ & $\begin{array}{l}60 \% \text { DF } \\
80 \% \text { WP } \\
75 \% \text { DF } \\
75 \% \text { DF }\end{array}$ & $\begin{array}{c}1 / 10 w t \text { oz } \\
7.5 \text { to } 12.5 w t \text { oz } \\
1 / \text { to } \% w t \text { oz } \\
\% \text { to } \% w t \text { oz }\end{array}$ \\
\hline
\end{tabular}

'Tank mix with 2,4-0 for applicution on whent and barley only.

\section{Rangeland and Permanent Grass Pastures}

Apply is to $1 \%$ pints of STINGER Herbieide per acre when weeds are young and actively growing. Grasses ar3 tolerant, but new grass seedlings may be injured to varying degrees until the grass has become well established. NOTE: Some forbs are susceptible to STINGER Herbicide. Do not spray pastures containing desirable forbs, especially legumes, unless injury can be tolerated. However, the stand and growth of established perennial grasses is usually improved after spraying, especially when rainfall is adequate and grazing is deferred.

Do not use hay or straw from treated areas for composting or mulching on susceptible broadleaf crops.

Conservation Reserve Program (CRP) For Seeding To Permanent Grasses Only

Do not use STINGER Herblcide if legumes or bentgress are a desired cover during CRP.

Grass grown on CRP acres cannot be grazed or used tor hay.
Conditions that stress grasses, such as drought, will increase potential for injury to the grass at all stages of growth. Do not use in newhy seeded areas until grass is established.

After CRP, do not plant broadleaf crops in treated areas until an adequately sensitive bioassay shows that no detectable clopyralid is present in the soll.

Brosdcast Applications (Ground): Applications of STINGER Herbicide should bo made when perennial grasses have become established (has tillered. developed a good seconday root system and shows good vigor) since most perennial grasses have shown better tolerance to the herbicide at that stage.

For control of actively growing weeds such as musk thistle. Canada thistle, and knapweed (sported, diffuse and Russian;, use is to 1\% pints per acre of STINGER Herbicide after the majority of basal leaves have emerged, but before bud stage. For the control of wild buckwheat, volunteer sunflower and musk thistle rosettes, apply is pint per acre of STINGER Herbicide. STINGER Herbicide can also be tank mixed with ts to $1 \mathrm{lb} / a c r e$ of 2,4-D where species present are sensitive to 2.4-D. For best results, use in 10 or more gallons of water per acre by ground. Increasing the rate of application can increase the risk of injury. Application prior to the flowering stage is recommended (still in the bud stage). 


\section{USE PRECAUTIONS}

Apply only once per 12 month period, except for sugar beets, field com and grasses grown for seed. A fallow treatment that precedes or follows a small grain application is also allowed. (See Directions for Use.)

Wheat, barley, oats, grasses, field com or sugar beets (including beets grown for seed) may be planted at anytime following treatment.

Afalfa, asparagus, canola, cole crops, mint, onions, safflower, and strawberries may be planted 12 months after treatment. Dry beans, soybeans, and sunflowers may also be planted at 12 months after treatment, except in soils with less than $2 \%$ organic matter receiving less than 15 inches of natural precipitation in the 12 month period following treatment. For these areas see SPECLAL CONDTIONS below.

To avoid potential phytotoxicity, all other crops, including pees, lentils, potatoes, and broadleaf crops grown for seed, should not be planted for 18 months after treatment unless the risk of injury is acceptable.

SPECLAL CONDTIONS: Residues of STINGER in plant tissues which have not completely decayed may affect succeeding susceptible crops. In areas defined previously as low in organic matter and precipitation, sensitive crops such as dry beans. soybeans, and sunflowers may be injured when planted 12 months atter treatment. Unless the risk of injury is acceptable, these crops should not be planted until 18 months after treatment. The potential for injury may be reduced by buming, removal, or incorporation of treated crop residues with a minimum of 2 supplemental Fall irrigations.

This product can affect susceptible broadleaf plants directly through foliage and indirectly by root uptake from treated soil. Therefore, do not apply STINGER Herbieide directly to or allow spray drift to come in contact with vegetables. flowers, grapes, tomatoes, potatoes, beans, lentils, peas. alfalfa, sunflowers, soybeans, satflower, or other desirable broadleaf crops and omamental plants or soil where these sensitive crops will be planted the same season.

Do not contaminate irrigation ditches or water used for irrigation or domestic purposes.

Avoid Spray Drift: Applications should be made to avoidspray dritt since very small quantities of the spray, which may not be visible, may severely injure susceptible crops during both growing and dormant periods. Use coarse sprays to minimize dritt since. under adverse weather conditions, fine spray droplets may dritt a mile or more. A dritt control or deposition agent such as Nalco-Trol may be used with this product to aid in reducing spray dritt. If used, follow all use recommendations and precautions on the product tabel.

Cround Applieation: To minimize spray drith, apply STINGER Herbicide in a total spray volume of 10 or more gallons per acre as largo-droplet, low-pressure spray. Refer to manufacturer's recommendations for additional information on gallons per acre, spray pressuro, sprayer speed, nozate types and arrangements, nozele heights above the target canopy, etc., for respective application cquipment Spot treatments should only be applied with a calibrated boom to prevent misspplication. With ground equipment, spray dritt can be lessened by keeping the spray boom as low as possible; by applying no more than 20 gallons of spray per acre; by using no more than 30 pounds spraying pressure with large droplet-producting nozzle tips; by spraying when wind velocity is low; and by stopping all spraying when wind exceeds 6 to 7 miles per hour. Do not apply with hollow cone-type insecticide or other nozales that produce a fine-droplet spray.
Do not apply by alrerath.

Do Not Transter Livestock trom treated grazing areas onto sensitive broadleaf crop areas without first allowing 7 days of grazing on an untreated pasture. Othenwise, unine may contain enough clopyralid to cause injury to sensitive broadleaf plants.

Do not move treated soll and avold situations where treated soil particles may blow into area where susceptible crops are grown. Violent windstorms may move soil particles. Hithis product is on soil particles and they are blown onto susceptible plants, visible symptoms may appear. Serious injury is unlikely. The hazard of movement of this product on dust is reduced if treated fietds are irrigated or if rain occurs shortly atter application. Straw from treated areas, or manure trom animals that have grazed treated areas, cannot be used for composting of mulching on ground where susceptible crops may be grown the following seeson. To promote herbicide decomposition, plant material should be evenly incorporated or bumed. Adequate moisture is also required to promote breakdown of plant residues which contain clopyralid.

Do not use in a greenhouse. Excessive amounts of this herbicide in the soil may temporarily inhibit seed germination or plant growth.

\section{Spray Equipment - Cleaning} Instructions

To avoid injury to desirable plants, equipment used to apply STINGER Herbicide should be thoroughty cleaned before reusing to apply any other chemicals.

1. Rinse and fush application equipment thoroughly after use at least three times with water, and dispose of rinse water in non-cropland area away from water supplies.

2. During the second rinse, add 1 ot of household ammonia for every 25 gallons of water. Circulate the solution through the entire system so that all internal surfaces are contacted (15-20 min.). Let the solution stand for several hours, preferably overnight.

3. Fhush the solution out the spray tank through the boom.

4. Rinse the system twice with clean water, recirculating and draining each timo.

5. Norjes and screens should be removed and cleaned separatefy.

\section{PRECAUTIONARY STATEMENTS}

\section{Environmental Hazards}

Clopyratid is a chemical which can travel (seep or lesch) through soil and under certain conditions contaminate grounctwater which may be used for irrigation or drinking purposes. Users are advised not to apply clopyralid where coik have a rapid to very rapid permesbility throughout the profile (such as loarmy sand to sand) and the water table of an undertying aquiter is shallow, of to soils containing sinkholes over limestone bedrock, severely fractured surfaces, and substrates which would allow direct introduction into an aquifer. Your boal agrieuttural agencies can provide further information on the type of soil ln your area and the beation of groundwater.

\section{STORAGE AND DISPOSAL}

Do not contaminate water, food or feed by storage or disposal

Storage: Store above $28^{\circ} \mathrm{F}$ or wam to $40^{\circ} \mathrm{F}$ and agitate before use.

Pasticide Disposat: Wastes resulting from the use of this product may be disposed of on site or at an approved waste disposal facility. 
Container Disposal (Metal): Do not reuse container. Triple rinse (or equivalent). Puncture and dispose of in a sanitary landfill, or by other procedures approved by state and local authorities.

Container Disposal (Plastic): Do not reuse container. Triple rinse (or equivalent). Puncture and dispose of in a sanitary landfill, or by incineration, or, if allowed by state and local authorities, by buming. If bumed, stay out of smoke.

\section{WARRANTY LIMITATIONS AND DISCLAIMER}

DowElanco warrants that this product conforms to the chemical description on the label and is reasonably fit for the purposes stated on the label when used in strict accordance with the directions therein under nomal conditions of use. THIS IS THE ONLY WARRANTY MADE ON THIS PRODUCT. NO OTHER EXPRESS AND NO IMPUED WARRANTY OF MERCHANTABILITY OR FTMNESS FOR A PARTICULAR PURPOSE IS MADE OUTSIDE OF THIS LABEL. Therefore, neither this warranty nor any other warranty of merchantability or fitness for a particular purpose, express or implied, extends to the use of this product contrary to label instructions fincluding conditions noted on the label, such as unfavorable temperatures, soil conditions, etc.), under abnomal conditions (such as excessive rainfall, drought, tomadoes. hurricanes, etc.) or under conditions not reasonably foreseeable to or beyond the control of seller.

When buyer or user sutfers losses or damages resulting from the use or handling of this product (including claims based on contract, negligence, strict liability, or other legal theories), buyer or user must promptly notity in writing DowElanco of any claims to be eligible to receive either remedy given below. The EXCLUSIVE REMEDY OF THE BUYER OR USER and the LMMT OF LABILTY of DowElanco or any other seller will be one of the following. at the election of DowElanco:

(1) Refund of purchase price paid by buyer or user for product bought, or

(2) Replacement of amount of product used.

The seller will not be liable for consequential or incidental damages or losses.

The terms of this Warranty Limitations And Disclaimer cannot be varied by any written or verbal statements or agreements. Any employee or sales agent of the seller is not authorized to vary or exceed the terms of this Warranty Limitations And Disclaimer in any manner.

\section{DowElanco}

Indianapolis, Indiana 46268 U.S.A. 
This sample label is current as of January 1, 1993. The product descriptions and recommendations provided in this sample label are for background information only. Always refer to the label on the product container before using Monsanto or any other agrichemical product.

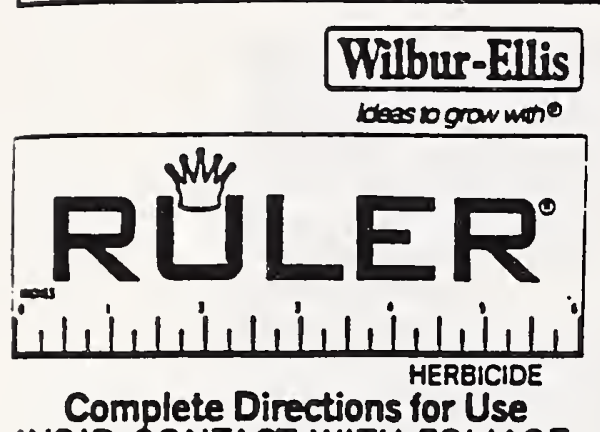

AVOID CONTACT WITH FOLIAGE GREEN STEMS, OR FRUIT OF CROPS, DESIRABLE PLANTS AND TREES, SINCE SEVERE INJURY OR DESTRUCTION MAY RESULT.

- Rula is a resstered trodemut ased under license

- Indemart of Wabur-Ellis

EPA Req. Na 524-326-2935

\begin{tabular}{ll}
\hline 1992.1 & $6 P L-1100.04 / C G$ \\
\hline
\end{tabular}

Read the entire label before using this product.

Use onty according to label instructions.

Read "UMIT OF WARRANTY AND LUABI!TT" betore buying ox using. If terms are not acceptable, return at once unopened.

REFORMULATION IS PROHIBITED. SEE INDIVIDUAL CONTAINER LABEL FOR REPACKAGING LMITATIONS.

\section{LUMIT OF WARRANTY AND LIABILITY}

This Company warrats that this product conforms to the chemical description on the label and is reasonably fit for the purposes set forth in the Complete Directions for Use tabel bookfet ("Directions") when used in accordance with those Directions under the conditions described therein. NO OTHER EXPRESS WARRANTY OR IMPLIED WARRANTT OF TTNESS FOR PARTICULAR PURPOSE OR MERCHANTABILITY IS MADE This warranty is also subject to the conditions and limitations stated herein.

Buyer and all users shall prompthy notify this Company of any claims whether based in contract. negligence. strict liability, other fort or otherwise.

Buyer and all users are responsible for all loss or damage from use $\alpha$ hand ling which results from conditions be fond tie control of this Company, ineludine, but not limited to. incompatibility with products othe than these set forth in the Directions. appliation to or contact with desirable vegetation, unusual weather, weather conditions which are outside the range considered normal at the application site and for the time period when the product is applied. as well as weather conditions which are outside the application ranges set forth in the Direc. tions. application in any manner not explicitly set forth in the Directions, moisture conditions outside the mois ture range specified in the Directions, or the presence of products other than those set forth in the Directions in of on the soil. crop or treated regetation.

THE EXCUSIVE REMEDY OF THE USER OR BUYER, AND THE UMMIT OF THE LABILTY OF THIS COMPANY OR ANY OTHER SEULR FOR ANY AND ALL LOSSES, INJURIES OR DAMAGES RESULTING FROM THE USE OR HAN. OLING OF THIS PRODUCT (INCLUDING CLAIMS BASED IN CONTRACT. NEGUGENCE, STRICT LLABILITY, OTHER TORT OR OTHERWISE SHAL BE THE PURCHUSE PRICE PAID BY THE USER OR BUYER FOR THE QUANTITY OF
THIS PRODUCT INVOLVED, OR, AT THE ELECTION OF THIS COMPANY OR ANY OTHER SELLER, THE REPUACE. MENT OF SUCH QUANTITY, OR, If NOT ACQUIRED BY PURCHASE, REPLACEMENT OF SUCH QUANTITY. IN NO EVENT SHALL THIS COMPANY OR ANY OTHER SEULER BE LIABLE FOR ANY INCIDENTAL CONSEQUENTIAL OR SPECIAL DAMAGES.

Buyer and all users are deemed to have accepted the terms of this UMIT OF WARRANTY AND LAABIUTY which may not be raried by any verbal or written agreement.

PRECAUTIONARY STATEMENTS
Hazards to
Humans and Domestic Animals

Keep out of reach of children.

\section{CAUTION!}

\section{MAY CAUSE EYE IRRITATION.}

Avoid contact with eyes, stin or clothing.

Wash thoroughty with soap and water after handline.

FIRST AID: If IN EYES, immediately flush with plenty of water for at leass 15 minutes. Get medical attention.

If ON SKIN, immediately flush with plenty of water. Wash clothing before reuse.

In case of a human health emergency imolving this product. Call Collect, day or night, (314) $694-4000$.

\section{Environmental Hazands}

Do not apply difectly to water. to areas where surface water is present or to intertidal areas below the mean high water mark. Do not contaminate water when dis. posing of equipment washwaters.

\section{Physical or Chemical Hazards}

Spray solutions of this product should be mixed, stored and applied using only stainless sted, aluminum, fiberelass plastic or plastic lined sted containers.

DO NOT MIX, STORE OR APPLY THIS PROOUCT OR SPRAY SOLUTIONS OF THIS PRODUCT USING GAL. VANIZED STEEL OR UNLNED STEEL (EXCEPT STAIN. LESS STEEU CONTAINERS OR SPRAY TANKS This product or sprey solutions of this product react with such containers and tants to produce hydrogen gas which misy form a highty combustible gas mixture. This ges mixture could flash or explode, causing serious personal injury. it ignited by open flame, spark, weldè's torch, lighted cigarette or other ignition source.

ACTIVE INGREDIENT:

-Glyphosite. N-phosphonomethyl) Etycine.

in the form of its isopropylamine salt ... 41.5\%

INERT INGREDIENTS:................. 58.5\%

100.08

- Contrins 480 srams per lite or 4 pounds per U.S. gallon of the active ingredient glyphosate in the form of its isopropylamine salt. Equivalent to 356 grams per litre or 3 pounds per U.S. gallon of the aeid, styphosate.

\section{DIRECTIONS FOR USE}

It is a violation of federal law to use this product in amy manner inconsistent with its labeling.

\section{Storage and Disposal}

Do not contaminate wrter, foodstutts, feed $\alpha$ seed by storage or disposal.

STORAGE:

STORE ABOVE $10^{\circ} \mathrm{F}\left(-12^{\circ} \mathrm{O}\right)$ TO KEEP PRODUCT FROM CRYSTAUUZING.

Coystals will settle to the bottom. If allowed to crystailiae. place in a wam room $68^{\circ} \mathrm{F}\left(20^{\circ} \mathrm{C}\right.$ ) for several days to redissotve and shake ox roll to mix well before using. DISPOSAL-

Wastes resulting from the use of this product that cannot be used or chemically reprocessed should be disposed of in a landfill approved for pesticide disposal or in accordance with applieable Federal, sate of local procedures.

Emptied container retains rapor and product residue. Observe all label salequards until containe is destroyed.

Do not reuse containes. Triple rinse containe. Then punc. ture and dispose of in a sanitary landfill, or by inciner. ation, $\alpha$, if allowed by state and local authorities. by burning. If bumed, stay out of smoke.

\section{GENERAL INFORMATION}

DO NOT APPLY THIS PRODUCT USING AERIAL SPRAY EQUIPMENT EXCEPT UNDER CONDITIONS AS SPECI. FIED WITHIN THIS LABEL

This product. a water soluble liquid, mixes resdily with wates to be applied as a toliar sproy fox the control or des truction of mos herbaceous plants It may be applied through most standard industrial or field-type sprayers after dilution and thorough mixing with wate in scoordance with label instructions.

This product moves through the plant from the point of foliage contact to and into the root sstem. Visible effects on most annual weeds oceur within 2 to 4 dass, but on most perennial weeds may not cocerr for 7 das or more. Extremely cool or cloudy weather following treatment my slow activity of this product and detry visual effects of control. Visible effects are a gradual wilting and rellowing of the plant which adrances to complete browning of aboveground growth and deterioration of understound plant parts

Unless othenvise specified on this tobel, deloy application unti veretrition has enrered and resched the sages described for control of such resetation under the "Weeds Controlled" section of this label. Unemerged plants arising from unathehed underround itizomes or root stocts of perennials will not be affected by the herticide and will continue to cow. For this rexson, best control of most perensial weeds is obtained when treat. ment is made at bate frowth sages approsching maturity.

Nwoys use the highes rate of this product per acre within the recommended rasge when (1) weed growth is herry of dense, of (2) weets are growing in an undisturbed (noncultinated) ares.

Do not treet weeds undes poor mowing conditions such as drought stress, disease of insect damage, as reduced weed control may result Reduced results may also $\propto$. cur when trerting weeds hervily covered with dust. 
Reduced control may result when applications are made to annual or perennial weeds that have been mowed. grazed. of cut. and have not been allowed to regrow to the recommended stage for treatment.

Rainfall or irngation occurring within 6 hours after application may reduce effectiveness. Heavy ranfall or irrigation within 2 hours after apolication may wash the chemical of the foliaze and a repeat treatment may be required.

This product does not provide residual weed control. For subsequent residual weed control, follow a labelapproved herbicide program. Read and carefully obsenve the cautionary statements and all other information appearing on the labels of all herbicides used.

Buyer and all users are responsible for all loss or damaze in connection with the use or handling of mixtures of Ruler with herbicides or other materials that are not expressly recommended in this labeling. Mixing this product with herbieides or other materials not recommended on this label may result in reduced pertormance.

for best results, spray coverage should be uniform and complete. Do not spray weed foliage to the point of iunoff.

Keep people and pets off treated areas until spray solytion has dried to prevent transfer of this product onto desirable vegetation.

DOMESTIC ANIMALS: This product is considered to be relatively nontoxic to dogs and other domestic animals: however, ingestion of this product or large amounts of freshly sprayed vegetation may result in temporary zastrointestinal urritation (vomiting, diarthea, colic, etc.). If such symptoms are observed, provide the animal with olenty of fluids to orevent dehydration. Call a veterinaran if symptoms persist for more than 24 hours.

\section{ATTENTION}

AVOID ORIFT. EXTREME CARE MUST BE USED WHEN APPLYING THIS PRODUCT TO PREVENT INIURY TO OESIRABLE PLANTS AND CROPS.

Do not allow the herbicide solution to mist, drip. drift. or splash onto desirable vegetation, since minute quantities of this product can cause severe damage or destruction to the crop. plants. or other areas on which treatment was not intended. The likelihood of injury oc. curring from the use of this product is greatest when winds are zusty or in excess of 5 miles per hour or when other conditions. including lesser wind velocities, will at low spray drift to occur. When spraying, awid combinations of pressure and nozzle type that will result in splatter or fine particles (mist) which are likely to drift. AVOID APPLYING AT EXCESSIVE SPEED OR PRESSURE.

NOTE: Use of this product in any manner not consistent with this label may result in injury to persons, animals or erops, or other unintended consequences. Keep contoiner closed to prevent spills and contamination.

MIXING; ADDTTIVES AND: APPLICATION INSTRUCTIONS.

APPLY THESE SPRAY SOLUTIONS IN PROPERLY MAIN. TAINED ANO CALIBRATEO EQUIPMENT CAPABLE OF DELIVERING OESIRED VOLUMES DO NOT APPLY WHEN WIND OR OTHER CONOITIONS FAVOR ORIT. HANO GUN APPLICATIONS SHOULD BE PROPERLY DIRECTED TO AVOID SPRAYING DESIRABLE PLANTS. NOTE: REDUCED RESULTS MAY OCCUR IF WATER CONTAINING SOIL IS USED. SUCH AS WATER FROM PONDS AND UNLINED OITCHES.

\section{MIXING}

This product requires use with a nonionic surtactant. When using this product, mix 4 to 8 quarts (1 to 2 per. cent solution) of a nonionic surfactant per 100 gallons of spray solution. Use the \&-quart rate for any surractant containing less than 50 percent active ingredient Read and carefully observe surfactant cautionary statements and other information appearing on the surfactant label. Wilbur-Ellis recommends the use of at least an $80^{\circ}$, ac. tive ingredient surfactant such as $R-11^{\circ}$ or similar type agrieultural surfactant.

- R-Il is a regustered tademart of Wribur-Ellis Company. This product mixes readily with water. Mix spray solutions of this product as follows. Fill the mixing or spray bnk with the required amount of water. Add the recommended amount of this product (see "Directions for Use" and "Weeds Controlled" sections of this label) and non. ionic surfactant near the end of the filling process and mix well. Remove hose from tank immediately atter filling to avoid siphoning back into the carrier source. During mixing and application, foaming of the spray solution may occur. To prevent or minimize foam. aroid the use of mechanical agitators, terminate by-pass and return lines at the bottom of the tank and. if needed. use an approved anti-foam or defoaming agent.

TANK MIXTURES

Always predetermine the compatibility of labeled tank mixtures of this product with water carrier by mixing small proportional quantities in adrance.

Mix labeled tank mixtures of this product with water as follows:

1. Place a 20 to 35 mesh screen or wetting basket over filling port.

2. Through the screen. fill the sprayer tank one-hall full with water and start agitation.

3. If a wettable powder is used. make a slurny with the water carrier. and add it SLOWh Y through the sereen into the tank. Contınue agitation.

4. If a flowable formulation is used. premix one part flowable with one part wates. Add diluted mixture SLOWLY through the screen into the tank. Continue agitation.

5. If an emulsifiable concentrate formulation is used. premix one part emulsifiable concentrate with two parts wates. Add diluted mixture SLOWh Y through the sereen into the tank Continue agitation.

6. Contınue filling the sprayer tank with water and add the required amount of this product near the end of the filling process

7. Add nonionic surtactant to the spray tank before completing the filling process.

8. Add individual formulations to the spray tank as follows wettable powder, flowable, emulsifiable concentrate. drift control additive, water soluble liquid followed by surfactant.

Maintain good agitation at all times until the contents of the tank are sprayed. If the spray mixture is allowed to settle. tharough agitation is required to resuspend the mixture before spraying is resumed.

Keep by-pass line on or near bottom of tank to minimize toaming. Screen size in noude or line strainers should be no finer than $\mathbf{5 0}$ mesh. Carefully select proper nozde to awoid spraying a fine mist. For best results with conventional ground application equipment, use flat fan nozles.
CLEAN SPRAYER AND PARTS IMMEDIATELY AFTER USING THIS PRODUCT BY THOROUGHLY FUSHING WITH WATER AND DISPOSE OF RINSATE ACCORDING TO LABELED USE OR OISPOSAL INSTRUCTIONS.

\section{ADDITIVES}

\section{AMMONIUM SULFATE}

The addition of 1 to 2 percent dry ammonium sulfate by weight or 8.5 to 17 pounds per 100 gallans of wates may increase the pertormance of this product and this product plus 2.4-D. Banvel" or residual herticide tank mixtures on annual and perennial weeds. The improvement in pertormance may be apparent where environmental stress is a concern. Low-quality ammonium sulfate may contain material that will not readily dissohe which could result in nozle tip pluzring. To determine quality, perform a jar test by adding 1/3 cup of ammonium sulfate to I gallon of water and agitate for 1 minute If undissolved sediment is observed, predissolve the ammonium sulfate in water and filter prior to addition to the spray tank If ammonium sulfate is added directly to the spray tank, add slowly with agitation. Adding too quickly may clog outtet lines. Ensure that ammonium sulfate is completely dissolved in the spray tank before adding herbicides or surfactant. Thoroughly rinse the spray system with clean water alter use to reduce corrosion.

NOTE: The use of ammonium sulfate as an additive does not preclude the need for surfactant Do not use her. bicide rates lower than recommended in this label.

neamet is a trademast of Sandaz. Ine.

\section{COLORANTS OR DYES}

Agriculturally approved colorants or marking dyes may be added to this product Calorants or dyes used in spray solutions of this product may reduce performance, especially at lowes rates of dilutions. Use colorants a: dyes according to manulacturef's recommendations.

\section{APPLICATION EQUIPMENT AND TECHNIQUES}

Do not apply this product through any type of irrigation system.

This product may be applied with the follown applica tion equipment

Aerial - Fixed Wing and Helicopter

Areadeas Spres

Controlled Dreplet Applieation (CON) - Hand-held or boom-mounted applicators which produce a spray consisting of a narrow range of droplet sizes.

Handheld and High-Volume Spres Equipment - Knapsack and backpack sprayers, pump-up preseure sprayers, handzuns, handwands, lances and other hand held spray equipment used to direct the spray onto weed foliage and vehicle-mounted. high-volume spray equipment for spray-to-wet applications.

Selectin Equipment - Recirculating sproyers, shielded sprayers and wiper applicators.

See the appropriate part of this section for specific rates of application and instructions.

\section{AERIAL EQUIPMENT}

Use the recommended rates of this product in 3 to 15 eallons of water per acre unless otherwise specilied on this label. See the "Weeds Controlled" section of this label for specitic rates Unless othernise specified. do 
not exceed one quart per acre (Aerial applications of this product may be made in annual cropping conventional tillage systems fallow and reduced tillage sys. tems and preharvest. Refer to the individual use area sections of this tabel for recommended volumes and application rates)

Avoid direct application to any body of water.

AVOID DRIT - DO NOT APPLY DURING INVERSION CONDITIONS. WHEN WINDS ARE GUSTY, OR UNDER ANY OTHER CONDITION WHICH FAVORS DRIFT. DRITT MAY CAUSE DAMAGE TO ANY VEGETATION CONTACT. ED TO WHICH TREATMENT IS NOT INTENDED. TO PRE. VENT INJURY TO ADJACENT DESIRABLE VEGETATION. APPROPRIATE BUFFER ZONES MUST BE MAINTAINED.

Coarse sprays are less likely to drift, therefore, do not use nozles or nozle configurations which dispense spray as fine spray droplets. Do not angle nazdes forward into the airstream and do not increase spray volume by increas. ing nozle pressure.

Orift control additives may be used. When a dritt control additive is used, read and carefully obsenve the cautionan statements and all other infermation appearing on the additive label.

Ensure unitorm applieation - To awoid streaked, uneven of overlapped application, use appropriate marking devices

Thoroughly wash aircratt, especially landing gear. after each day of spraying to remove residues of this product accumulated during spraving or from spills PROLONGED EXPOSURE OF THIS PRODUCT TO UNCOATED STEEL SURFACES.MAY RESULT IN CORROSION AND POSSIBLE FALURE OF THE PART. LANDING GEAR ARE MOST SUSCEPTIBLE The maintenance of an organic coating (paint) which meets aerospace specification MILC-38413 may prevent corrosion.

\section{BROADCAST EQUIPMEHT}

For control of annual of perennial weeds listed on this bbel using brodeast equipment - Use the recommended rates of this product in 3 to 40 gallons of water pee acre as a broadeast sproy unless otherwise specified on this label. See the "Weeds Controlled" section of this label for specific rates. As density of weeds increases. spray volume should be increased within the recommended range to ensure complete coverage. Carefully select proper noude to aroid spraying a fine mist for best results with ground applieation equipment. use flat fan nazales Check for eren distribution of sproy droplets.

\section{CONTROUED DROPLET APPUCATION (CDA)}

The rate of this product applied per acre by vehiclemounted CDA equipment must not be less than the anoumt recommended in this label when applied by conrentional broadcast equipment. for rehicie-mounted COA equipment apply 3 to 15 gallons of water pes acre.

For the control of labeled annual weeds with hand-held COA units, apply a 20 percent solution of this product plus a 5 percent solution of nanionic surfactant at a flow rate of 2 fluid ounces per minute and a walking speed of 1.5 MPH (l quart pes acre). For the control of labeled perennial weeds, apply a 20 to 40 percent solution of this product plus a 5 to 10 percent solution of nonionic sur. factant at a flow rate of 2 fluid ounces per minute and a walking speed of 0.75 MPH ( 2 to 4 quarts per acre)

Controlled droplet application equipment produces a spray pattern which is not easity visible. Extreme care

must be exercised to awoid sproy or drift contacting the folizge or any other green tiscue of desirable vegetation as tamage or destruction ma result.

\section{HAND.HED and \\ HIGH-YOUWE EQUIPMENT \\ Use coarse sprays onty.}

Mix this product in clean wrtes and apply to toliage of regeistion to be controlled. For applieations made on a sprayto-wet basis, spray concrese should be unitorm and complete. Do not spren to the point of runoff.

For control of annual ested on this bbed, apply 0.5 percent solution of this product plus nonionic surfactant to weeds less than 6 inches in height or runner length. Apply prior to seedhead formation in grasses or bud for. mation in broadleat Nlow three or more days before tillage or mowing

For annual weeds ore 6 inches tall, or untess othenwise specified, use a 1 percent sctution. For best resultts, use 12 percent solution co brods tocontrol perenniaks, such as bermudagrass, doct fied bindweed, hemp dogtane, milkweed and Canada thiste

Less than complete coreane of weeds may result from the use of spray equipmentesigned for motorized spot trestments. Where less then complete corerase of annual weeds occurs, use a 5 pecent salution. Do not reduce recommended concentrations of this product when adding surfactant.

Prepare the desired rolume of sprey solution by mixing the amount of this procuct i water as shown in the fot lowing table:

\begin{tabular}{|c|c|c|c|c|c|}
\hline \multirow[b]{3}{*}{$\begin{array}{l}\text { DESIRED } \\
\text { VOLUME }\end{array}$} & \multicolumn{4}{|c|}{ Spros Satrion } & \\
\hline & \multicolumn{5}{|c|}{ AMOUNT OF RULER० } \\
\hline & $1 / 28$ & 18 & $1-1 / 29$ & 28 & 58 \\
\hline Sattan & \multicolumn{3}{|c|}{$2 / 3 \propto 1.1 / 3 \propto 2 \propto 2$} & \multicolumn{2}{|c|}{$2-2 / 3 \alpha 26-1 / 2 \alpha$} \\
\hline $\begin{array}{l}25 \text { Eations } \\
100 \text { gallons }\end{array}$ & $\begin{array}{l}1 \text { ot } \\
2 \text { qt. }\end{array}$ & $\begin{array}{l}140 \\
18\end{array}$ & $\begin{array}{l}1-1 / 2 \text { qt } \\
1-1 / 2 \text { gal }\end{array}$ & $\begin{array}{l}2 \text { of } \\
2 \mathrm{eal}\end{array}$ & 5 at \\
\hline
\end{tabular}

2 tablespoons = 1 frid ance

Add surfactant at a rece of 1 to 2 ar pea zalion of spray mix.

For use in knapect saraces it is sueperted that the recommended amount of this product be mixed with water in a lares contere. Frd sprayed with the mixed solution and add the corred amount of surtactant.

\section{- - SEIETTE EQUIPMENT}

This product $\mathrm{mr}$ be apoind throush a recirculating spray sstem. a shiedded appicator, or a wiper a pplicator after dilution and turcod mixing with wates to list. ed weeds growing in an wereop site specified on this label and onty when specifally recommended in crop. ping systems

A recirculating spres sothe directs the spry solution onto weeds growing aboce desirable resetstion, while sproy satution nat interated ty weeds is coliected and returned to the spros tal for reuse.

A shieided applicur frees the herbicide edution onto

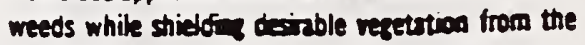
herbicide.

A wiper applictor so the herbicide solution onto weeds by nubbing the reed rith an aboortent matterial containing the berticie sotution.

AVOID CONTACT WTH DCSRABLE VEGETANON.

Contact of the hatcice staion with the desiable ress tation may result in damage or destruction. Applicators used above desired repetation should be adjusted so that the lowest spray stream or wiper contact point is at least two inches above the desirable vegetation. Oroplets, mist, fosm, of splattes of the herbicide solution settling on desirable regetation may result in discoloration, stunting, or destruction.

Applications made above the coops should be made when the weeds are a minimum of 6 inches above the desirzble regetation. Better results may be obtained when more of the weed is exposed to the herbicide solution. Weeds not contacted by the herbicide solution will not be affected. This may oceur in dense clumps, severe intetations, or when the height of the weeds varies so that not all weeds are contacted. In these instances, repeat treatment may be necessary.

See the "Weeds Controlled" section of this label for recommended stage of growth for specific weeds.

NOTE

- Maintain equipment in good operating condition. Aroid leakage ar dripping onto desirable vegetation.

- Adjust height of applicator to ensure adequate contact with weeds.

- Keep nozale tips and wiping surfaces clean.

- Keep sprar patterns aligned into recovery chambes of the recirculating sprayer.

- Keep shields on shielded applicators adjusted to pro. tect desirable regetation.

- Maintain recommended roller RPM on rolles applieztors while in use.

- Keep wiper material at proper degree of soturation with herbicide solution.

- DO NOT use wiper equipment when weeds are wet.

- DO NOT operate equipment at ground speeds greates than $5 \mathrm{mph}$. Weed control may be affected by speed of application equipment. As weed density increases. reduce equipment ground speed to ensure good coverare of weeds.

- Be aware that on sloping ground the herbicide solution my migrate, ausing dripping on the lower end and drying on the uppes end of a wipes applicator.

- Variation in equipment design may affect weed convol. Wrth wipes applicators, the wiping moterial and its orientation must allow delivery of sufficient quan tities of the recommended herbicide solution directly to the wed.

- Care must be then with all tppes of wipers to ensure that the absorbent material does not become over. anted, causing the herbicide to drip on desirable resetution.

- Mix only the amount of solution to be used during a coedry period, as reduced activity may result from we of leftores solutions. With all equipment, drain and dean sprayes and wiper parts immediately after using this product by thoroughty flushing with water.

\section{Reclrouranne SPRAYERS}

Recirabatins sprayes calibration is made on the basis of cround speed and delinery rolume. Two procedures an be used to calibrate: (1) determiaing the discharge be ing delinered pes minute. then operate at the designataf ground speed, or (Z) setect the desired zround speed and then adjust the sprayes to delives the recommenoad rolume per minute (this mor require nazde changes) Use the appropriate time table below. 
Do not operate at nozzle pressure above 20 PSI.

Table 1. Use this table when calibrating box or row-type recirculatıng sprayers. Box or row-type sprayer calibra ton is based on the total discharge collected per row. Use only straight stream or $15^{\circ}$ fan-type nozjes.

-VOLUME PER MINUTE PER ROW
\begin{tabular}{cc} 
MPH & Fluid Ounces \\
\cline { 3 - 3 } 3 & 26 to 35 \\
3 & 38 to 51 \\
.5 & 51 to 68 \\
65 to 86
\end{tabular}

- NOTE: Be certain the amount collected is for all spray streams treating one row.

Table 2. Use this table when calibrating broadeast type recirculating sprayers, Broadeast recirculating sprayer calibration is based on the diseharge collected per minute from one nozzle on a 20-inch spacing.

VOLUME PER MINUTE PER NOZZLE

$\begin{array}{cc}\frac{M P H}{2} & \text { Fluid Ounces } \\ & 7 \text { to } 9 \\ 4 & 10 \text { to } 13 \\ 5 & 13 \text { to } 18 \\ 16 \text { to } 22\end{array}$

When applied as recommended under the conditions deseribed for recireulating sprayers. this product will control the following weeds growing a minimum of 6 inches above desirable vegetation.

Perennial Broadleaf Weeds - To SUPPRESS the following weeds. mix in a ratio of 4 quarts of this product in 20 gallons of water and apply as directed.

$$
\begin{aligned}
& \text { Dotbane, hemp Milkweed } \\
& \text { Apocynum cannabinum Asclepias syriaca }
\end{aligned}
$$

Perennial Grases and Annual Broadleaf Weeds - To contol the following weeds, mix in a ratio of 3 quarts of this product in $\mathbf{2 0}$ gallons of water and apply as directed:

$\begin{array}{cc}\text { Cocklebur } & \text { Pigweed, redroot } \\ \text { Xanthium } & \text { Amaranthus } \\ \text { strumarium } & \text { retroflexus } \\ \text { Johnsengrass } & \text { Sunflower } \\ \text { Sorghum halepense } & \text { Melianthus annuus }\end{array}$

Annud Grass - To CONIROL the following weeds. mix in a ratio of 2 quarts of this product in 20 gallons of water and apply as directed:

$\begin{array}{ll}\text { Com } & \text { Shattereane } \\ \text { Zea mass } & \text { Sorghum bicolor }\end{array}$

\section{SHIELDED APPLICATORS}

When applied as directed under conditions deseribed for shielded applicators. this product will control those weeds listed in the "Weeds Controlled" section of this. label.

Shielded applicators which apply the herbicide solution as a spray band should be calibrated on a broadeast

\begin{tabular}{|c|c|c|c|c|}
\hline $\begin{array}{l}\text { Band width } \\
\text { in inches } \\
\text { Row width } \\
\text { in inches }\end{array}$ & $x$ & $\begin{array}{c}\text { Herbicide } \\
\text { broadcast } \\
\text { RATE } \\
\text { per acre }\end{array}$ & $=$ & $\begin{array}{c}\text { Herbicide } \\
\text { band RATE } \\
\text { per acre }\end{array}$ \\
\hline $\begin{array}{l}\text { Band width } \\
\text { in inches } \\
\text { Row width } \\
\text { in inches }\end{array}$ & $x$ & $\begin{array}{l}\text { Broadeast } \\
\text { vouUME of } \\
\text { solution } \\
\text { per acre }\end{array}$ & $=$ & $\begin{array}{l}\text { Band VOLUME } \\
\text { of solution } \\
\text { per acre }\end{array}$ \\
\hline
\end{tabular}
equivalent rate and volume basis. To determine these:
Use nozzles that provide uniform coverage within the treated area. EXTREME CARE MUST BE EXERCISED TO AVOID CONTACT WITH DESIRABLE VEGETATION.

For specific rates of application and instructions for control of vrrious annual and perennial weeds, see the "Weeds Controlled" section of this label.

\section{WIPER APPUCATORS}

Wiper applicators include either roller or wick devices which physically wipe appropriate concentrations of amounts of this produet directly onto the weed. Equipment must be designed, maintained, and operated to prevent the herbicide solution from contacting desirable vegetation. Operate this equipment at ground speeds no greater than $5 \mathrm{mph}$. Performance may be improved by reducing speed in areas of heary weed infestations to ensure adequate wiper saturation. Better results may be obtained if two applications are made in opposite directions.

For Roller Applieators - Mix I gallon of this p. oduct in enough water to prepare 10 gallons of herbicide solution (10 percent solution). Apply this solution to perennial weeds or annual broadleaf weeds listed in this "Wiper Applicators" section.

Mix I gallon of this product in enough water to provide 20 gallons of herbicide solution (5 percent solution). Apply this solution to annual grasses listed in this "Wipes Applicators" section.

Roller speed should be maintained at 40 to 60 RPM.

For Wiek or Wiper Applieaters - Mix I gallon of this product in 2 gallons of water to prepare a 33 percent solution. Apply this solution to weeds listed in this "Wiper Applicators" section:

In severe infestations, reduce equipment ground speed to ensure that adequate amounts of this product are wiped on the weeds $A$ second treatment in the opposite direction may be beneficial.

Do not permit herbicide solution to contact desirable regetation.

When applied as recommended under the conditions described for "Wiper Applicators", this product CONTROLS the following weeds:

\begin{tabular}{|c|c|}
\hline $\begin{array}{l}\text { Corn } \\
\text { 2ea mass }\end{array}$ & $\begin{array}{l}\text { Oje, comman } \\
\text { Secale cereale }\end{array}$ \\
\hline $\begin{array}{l}\text { Panieum, Terss } \\
\text { Panicum texanum }\end{array}$ & $\begin{array}{l}\text { Shattereane } \\
\text { Sorghum bicolor }\end{array}$ \\
\hline
\end{tabular}

\section{ANHUAL GRASSES}

\section{ANNUAL BROADLEAVES}

$\begin{array}{lc}\text { Sictlepod } & \text { Stapbri, bristhy } \\ \text { Cassia obtusifolia } & \text { Aeanthospermum } \\ \text { Spanishneedles } & \text { hispidum } \\ \text { Bidens bipinnata } & \end{array}$

When applied as recommended under the conditions described for "Wiper Applicators". this product SUPPRESSES the following weeds:

\section{ANNUAL BROADLEAVES}

\begin{tabular}{|c|c|}
\hline $\begin{array}{l}\text { Pigweed, redroot } \\
\text { Amaranthus } \\
\text { retroflexus }\end{array}$ & $\begin{array}{l}\text { Vetretleaf } \\
\text { Abutilon theophrasti }\end{array}$ \\
\hline \multicolumn{2}{|l|}{$\begin{array}{l}\text { Rapweed, common } \\
\text { Ambrosia artemisiifolia }\end{array}$} \\
\hline \multicolumn{2}{|l|}{ PEREHNIAL GRASSES } \\
\hline $\begin{array}{l}\text { Bermudagrass } \\
\text { Cynodon dactylon }\end{array}$ & $\begin{array}{l}\text { Smutgrass } \\
\text { Sporobolus poiretii }\end{array}$ \\
\hline $\begin{array}{l}\text { Guineagrass } \\
\text { Panicum maximum }\end{array}$ & $\begin{array}{l}\text { Vaseygrass } \\
\text { Paspalum unillei }\end{array}$ \\
\hline $\begin{array}{l}\text { Johnsongress } \\
\text { Sorghum halepense }\end{array}$ & \\
\hline \multicolumn{2}{|c|}{ PERENKIAL BROADLEAVES } \\
\hline $\begin{array}{l}\text { Dogbane, hemp } \\
\text { Apocynum cannabinum }\end{array}$ & $\begin{array}{l}\text { Mightshade, sibverleat } \\
\text { Solanum elaeagnifolium }\end{array}$ \\
\hline $\begin{array}{l}\text { Milkweed } \\
\text { Ascelepias srizes }\end{array}$ & $\begin{array}{l}\text { Thistle, Canada } \\
\text { Cirsium arvense }\end{array}$ \\
\hline
\end{tabular}

\begin{tabular}{cc}
\hline Begsanweed, Florida & Ragweed, giant \\
Desmodium & Ambrosia trifida \\
tontuasum & Sunflower \\
Dodtennel & Helianthus anfiuus \\
Eupatarium & Mhistle, mush \\
Capillifiorium & Carduus nutans
\end{tabular}

\section{WEEDS CONTROLLED}

This herbicide controls many annual and perennial grasses and broadleaf weeds.

\section{ANHUAL HEEDS}

- Apply to actively growing grass and broadleal weeds.

- Allow at least 3 days after treatment before tillage.

- For maximum agronomic benefit. apply when weeds are 6 inches or less in height.

- To prevent seed production, applications should be made prior to seedhead formation.

- This product does not provide residual control; therefore, delay application until maximum weed emer. gence. Repeat treatments may be necescary to control later germinating weeds.

\section{LOH-VOLUME BROADCAST APPLICATION (LOW-RATE TECHNOLOGM}

When applied as directed under the conditions described, this product will control the weeds listed befow when water carrier volumes of 3 to 10 galions per acre for ground applications and 3 to 5 gallons per acre for aerial applications are recommended. (See the "Aerial Equipment" section of this label for approved sites.)

\section{NOTE}

- The addition of 2 percent $d r y$ ammonium sulfate by weight or 17 pounds pes 100 gallons of water may increase the performance of this product on annual weeds The improvement in performance may be apparent where emvironmental stress is a concern. Refes to the "Mixing. Additives and Application Instruc. tions" section of this label.

- Do not tonk-mix with soit-esidual herbicides when using these rates unless othenwise specified.

- For weeds that have been mowed. araed or cut allow regrowth to oceur prior to treatment.

- Refer to the "Tanh Mixtures" portion of this section

\begin{tabular}{|c|c|c|}
\hline WEED SPECIES & $\begin{array}{l}\text { MLXIMUM } \\
\text { MEIGHTI } \\
\text { LEMGTH }\end{array}$ & $\begin{array}{c}\text { RAIE PER } \\
\text { ACREE: } \\
\text { mulo ouncess }\end{array}$ \\
\hline $\begin{array}{l}\text { Fartail } \\
\text { Setzrta spo. }\end{array}$ & $12^{\circ}$ & 802. \\
\hline
\end{tabular}
for control of additional broadleaf weeds. 


\begin{tabular}{|c|c|c|}
\hline WEED SPECIES & $\begin{array}{l}\text { MAXIMUM } \\
\text { HEIGHT/ } \\
\text { LENGTH }\end{array}$ & $\begin{array}{l}\text { RATE PER } \\
\text { ACRE } \\
\text { (nUID OUNCESI }\end{array}$ \\
\hline $\begin{array}{l}\text { Barnyardgrass } \\
\text { Echinochlos } \\
\text { crusegalli }\end{array}$ & \multirow[t]{8}{*}{$\begin{array}{c}6^{\prime \prime} \\
10104^{\circ} \\
14106^{\circ}\end{array}$} & \multirow[t]{14}{*}{$\begin{array}{l}1202 . \\
1602.11 \\
2402.1)\end{array}$} \\
\hline $\begin{array}{l}\text { Bluegrass, annual } \\
\text { Poa annua }\end{array}$ & & \\
\hline $\begin{array}{l}\text { Brome, downyo } \\
\text { Bromus tectorum }\end{array}$ & & \\
\hline $\begin{array}{l}\text { Mustard, blue } \\
\text { Charispara tenella }\end{array}$ & & \\
\hline $\begin{array}{l}\text { Mustard, bans } \\
\text { Descurainis pinnata }\end{array}$ & & \\
\hline $\begin{array}{l}\text { Mustard, lumble } \\
\text { Sisymbrium altissimum }\end{array}$ & & \\
\hline $\begin{array}{l}\text { Mustard, wild } \\
\text { Sinspis amensis }\end{array}$ & & \\
\hline $\begin{array}{l}\text { Spum, umbrella } \\
\text { Holosteum } \\
\text { umbellatum }\end{array}$ & & \\
\hline $\begin{array}{l}\text { Barley } \\
\text { Hordeum vulgare }\end{array}$ & \multirow[t]{5}{*}{$12^{\prime \prime}$} & \\
\hline $\begin{array}{l}\text { Rye } \\
\text { Secale cereale }\end{array}$ & & \\
\hline $\begin{array}{l}\text { Sondbur, field } \\
\text { Cenchrus spo. }\end{array}$ & & \\
\hline $\begin{array}{l}\text { Shatterane } \\
\text { Sorghum bicolor }\end{array}$ & & \\
\hline $\begin{array}{l}\text { Stinkeres } \\
\text { Eragrostis } \\
\text { cilianensis } \\
\end{array}$ & & \\
\hline $\begin{array}{l}\text { Wheat } \\
\text { Triticum aestivum }\end{array}$ & $18^{\prime \prime}$ & \\
\hline $\begin{array}{l}\text { Morninestory } \\
\text { Ipomoes Spp. }\end{array}$ & \multirow[t]{2}{*}{$2^{\infty}$} & \multirow[t]{13}{*}{1602} \\
\hline $\begin{array}{l}\text { Sietleppod } \\
\text { Cassia obfusifolia }\end{array}$ & & \\
\hline $\begin{array}{l}\text { Bluegrases, bulbous } \\
\text { Pas bulboss }\end{array}$ & \multirow[t]{11}{*}{$6^{\prime \prime}$} & \\
\hline $\begin{array}{l}\text { Cheat } \\
\text { Bromus secalinus }\end{array}$ & & \\
\hline $\begin{array}{l}\text { Chichwoed, conmea } \\
\text { Stelloris medis }\end{array}$ & & \\
\hline $\begin{array}{l}\text { Chichweed, mouseen } \\
\text { Cerastium vulgatum }\end{array}$ & & \\
\hline Com & & \\
\hline $\begin{array}{l}\text { Contereses jointed } \\
\text { regilops cglindrica }\end{array}$ & & \\
\hline $\begin{array}{l}\text { Grousted, commen } \\
\text { Senecio rulgaris }\end{array}$ & & \\
\hline $\begin{array}{l}\text { Horsewned/Marestail } \\
\text { Canyza canadensis }\end{array}$ & & \\
\hline $\begin{array}{l}\text { Lambsauartes, common } \\
\text { Chenopodium album }\end{array}$ & & \\
\hline $\begin{array}{l}\text { Pennuchas, fild } \\
\text { Fanmeed } \\
\text { Molaspi anense }\end{array}$ & & \\
\hline $\begin{array}{l}\text { Rectet Lendon } \\
\text { Sisymbrium isio }\end{array}$ & & \\
\hline
\end{tabular}

\begin{tabular}{|c|c|c|c|c|c|}
\hline WEED SPECIES & $\begin{array}{l}\text { MNXIMUA } \\
\text { HEIGHTI } \\
\text { LENGTH }\end{array}$ & $\begin{array}{c}\text { RATE PER } \\
\text { ACRE } \\
\text { nuU OO OUNCESI } \\
\end{array}$ & WEED SPECIES & $\begin{array}{l}\text { MAXIMUM } \\
\text { HEIGHT/ } \\
\text { LENGTH }\end{array}$ & $\begin{array}{c}\text { RATE PER } \\
\text { ACRE } \\
\text { MUID OUxELSI }\end{array}$ \\
\hline $\begin{array}{l}\text { Ryegrass, Italian } \\
\text { Lolium multiflorum } \\
\text { Shepherdspurse } \\
\text { Capsella bursa-pastaris } \\
\text { Spurge, annual } \\
\text { Euphorbia SpD. }\end{array}$ & $6^{\prime \prime}$ & $160 z$ & $\begin{array}{l}\text { Primrose, cortleal } \\
\text { ewening } \\
\text { Oenothers beiniate } \\
\text { Pustey, Forida } \\
\text { Richardis seabra } \\
\text { Sicllepod }\end{array}$ & $12^{\prime \prime}$ & 3202 \\
\hline $\begin{array}{l}\text { Buttereup } \\
\text { Ranunculus spo. } \\
\text { Cocklebur }\end{array}$ & $12^{\circ}$ & & $\begin{array}{l}\text { Cessis abtusidalis } \\
\text { Spanishneedles } \\
\text { Bidens bipinnats }\end{array}$ & & \\
\hline $\begin{array}{l}\text { Xanthium } \\
\text { strumarium } \\
\text { Crabgrass } \\
\text { Oigitaria spo. }\end{array}$ & & & $\begin{array}{l}\text { Flares } \\
\text { Erodium spp. } \\
\text { Sprandietop } \\
\text { Leptochion spp. }\end{array}$ & $12^{\prime \prime}$ & 4802 \\
\hline
\end{tabular}

Dwardandelion

Krigis cespitoss

Falseflax, smallseed

Comelins microcarps

Poxtail, Cardina

Nopecurus

carolinianus

Johnsongrass, seedlin!

Sorghum halepense

Oats, wild

Avens fatus

Panicum, fall

Panicum dichotomillosum

Panicym, Tesas

Panicum texanum

Pigweed, redreot

Amaranthus

retrollexus

Pigweed, smooth

Amaranthus hybridus

Witetigress

Panicum capillare

\begin{tabular}{|c|c|c|}
\hline $\begin{array}{l}\text { Sickleped } \\
\text { Coscio abtusifolia } \\
\text { Signalerass, breadleat } \\
\text { Brachioria } \\
\text { platyphytb }\end{array}$ & 3 to $4 "$ & 2402 \\
\hline $\begin{array}{l}\text { Horsewead/Marestail } \\
\text { Conyza canadensis } \\
\text { Lambsquarter, common } \\
\text { Chenopodium album } \\
\text { Spurze, annual } \\
\text { Euphorbio spp. }\end{array}$ & 7 to $12^{\prime \prime}$ & \\
\hline $\begin{array}{l}\text { Rice, red } \\
\text { Onen satin } \\
\text { Teaweed } \\
\text { Sids spinos } \\
\end{array}$ & $4^{\circ}$ & $32 a z$ \\
\hline $\begin{array}{l}\text { Sprandetep } \\
\text { Leptochlas spp. }\end{array}$ & 6" & \\
\hline 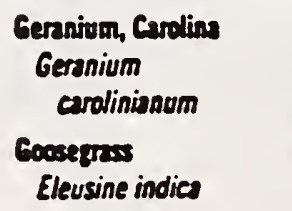 & $12^{\circ}$ & \\
\hline
\end{tabular}

Use these rates to control barmyidgrass in Alabama. Ntansers, Misciscippi, Lovisiana, Missouri and Texas for preplant treatments.

- For control in no-ill gstems, use 16 fluid ounces pes sere

- For those rotes less than 32 fluid ounces per acre, this product at rates up to 32 fluid ounces per acce may be used where herm weed densities exist.

\section{a TAKK MIXTURES \\ RULERO pluS BAHVEL plus NOHIOHIC SURFACTANT \\ RULER plus 2,4D \\ ples NOHIONIC SURFACTANT}

These tank motures are recommended for use in fallow and reduced tillage areas onhy. Follow use directions as eiven in this "Low-Volume Bradeast Applieation" section.

This product plus Banvel $\propto 2,40$ will control the annual rrases and brastleat weeds previoushy listed for this product alone at the indicated heights (except 8 huid ounces per acre appliations), plus the following brosoleat weeds for those weeds previoushy listed at 8 fluid ounces of this product alone per acre, use 12 fluid cunces in these tank mixtures.

MOTE: Refer to the specific product labels for coop roution restictions and autionary statements of all products used in tunk mistures Some copp injury mry cecus if Band is applied within 45 drys of plantine. The addition of Baned in a miature with this product mory provide shartterm residual control of selected weed species.

Apph 12 to 16 fluid ounces of this product plus $0.25 \mathrm{lb}$. $2 i$ of Baned or 0.5 pound $2 i$ of 2,40 pes acre to contod dense populations of the following anneal brodieaf weeds when less than the beight indicated.

\section{Coctlberer (12) Menaingtion (6")}

Xattium stumerium Ipomoes spo.

rechise 169

Koebin secouria

Pigwied, nedroot (12") Amanathes retroflexus

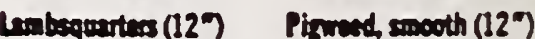

Arenopodivan album Amaranthos hyoridus

Letwee, prictly (6) Tisth, Rewios (12")

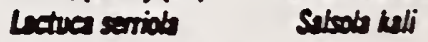

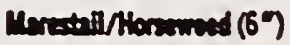

Conpe caredensis

contralled with Bamel tank mixture only. 
Apply 16 fluid ounces of this product plus 0.5 pound a.i. of 2,4-D per acre to control the following annual broadleaf weeds when less than 6 inches in height.

\begin{tabular}{|c|c|}
\hline $\begin{array}{l}\text { Ragweed, commen } \\
\text { Ambrosia artemisifiolia }\end{array}$ & $\begin{array}{l}\text { Smartweed, Pennastrania } \\
\text { Polygonum } \\
\text { Denstranicum }\end{array}$ \\
\hline $\begin{array}{l}\text { Rapweed, giant } \\
\text { Ambrosia trifida }\end{array}$ & $\begin{array}{l}\text { Vehetleal } \\
\text { Abutilon theophrasti }\end{array}$ \\
\hline
\end{tabular}

When applied as directed under the conditions described, this product will control the weeds listed be low when water carrier volumes are 10 to 40 gallons per acre for ground applications.

Use 1 quart of this product per acre if weeds are less than 6 inches tall. If weeds are over 6 inches tall, use 1.5 quarts of this product per acre. If weeds have been mowed, grazed. or cut, allow adequate time for new growth to recommended stages prior to treatment. These rates will also provide control of weeds listed in the "LowVolume Brosdcast Application" section.

\begin{tabular}{|c|c|}
\hline \multicolumn{2}{|c|}{ WEED SPECIES } \\
\hline $\begin{array}{l}\text { Bateamapple* } \\
\text { Momordica charantia }\end{array}$ & $\begin{array}{l}\text { Panieum } \\
\text { Panicum spp. }\end{array}$ \\
\hline $\begin{array}{l}\text { Basia, fivehook } \\
\text { Bassia hyssopifolia }\end{array}$ & $\begin{array}{l}\text { Ragweed, common } \\
\text { Ambrosia artemisiifolia }\end{array}$ \\
\hline $\begin{array}{l}\text { Brome } \\
\text { Bromus spo. }\end{array}$ & $\begin{array}{l}\text { Ragweed, giant } \\
\text { Ambrosia trifida }\end{array}$ \\
\hline $\begin{array}{l}\text { Fiddlenect } \\
\text { Amsinckia spo. }\end{array}$ & $\begin{array}{l}\text { Smartweed, Pennsglvanis } \\
\text { Polygonum }\end{array}$ \\
\hline $\begin{array}{l}\text { Plaxleaf, hairy } \\
\text { Conyza bonariensis }\end{array}$ & $\begin{array}{l}\text { pensyivanicum } \\
\text { Sowthistle, annual }\end{array}$ \\
\hline $\begin{array}{l}\text { Feabane } \\
\text { Erigeron spp. }\end{array}$ & Sonchus oleraceus \\
\hline $\begin{array}{l}\text { Kochia } \\
\text { Kochia seoparia }\end{array}$ & $\begin{array}{l}\text { Sunflower } \\
\text { Helianthus annuus }\end{array}$ \\
\hline $\begin{array}{l}\text { Lettuce, priecly } \\
\text { Lactuca serriola }\end{array}$ & $\begin{array}{l}\text { Thistle, Russian } \\
\text { Salsola kali }\end{array}$ \\
\hline & $\begin{array}{l}\text { Yelvetleaf } \\
\text { Abution theophrasti }\end{array}$ \\
\hline
\end{tabular}

-Apply with hand-held equipment only.

\section{PERENMIAL MEEDS}

Apply this product as follows to control or destroy most perennial weeds:

NOTE: If weeds have been mowed or tilled. do not treat until plants have resumed active growth and have reached the recommended stages of growth.

Repeat treatments may be necessary to control weeds regenerating from underground parts or seed. Repeat treatments must be made prior to crop emergence.

The addition of 1 to 2 percent $d$ y ammonium sulfate by weight or 8.5 to 17 pounds per 100 gallons of water may increase the performance of this product on perennial weeds the improvement in performance may be apparent where emvironmental stress is a concern. Reler to the "Mixine Additives and Application Instructions" section of this label.

When applied as recommended under the conditions deseribed. this product WILL CONTROL the following PERENNIAL WEEDS:

$\begin{array}{lc}\text { Alfalia } & \text { Johnsongrass } \\ \text { Medicago sotiva } & \text { Sarghum halepense } \\ \text { Alligatorweed" } & \text { Riturugrass } \\ \text { Alternanthera } & \text { Pennisetum } \\ \text { philoreroides } & \text { clandestinum }\end{array}$

Artichake, Jerusalem Mnapweed
Helianthus tuberosus Centaur

Bahiages

Paspalum notatum

Lantana

Bentgrass

Arrostis spp.

Bermudarras

Cynodon dactylon

Bermudagrass water

(Inoterase)

Paspalum distichum

Bindweed, field

Convolvulus arvensis

Bluegras, Mentuch

Pos spp.

Bueweed, Terss

Helianthus ciliaris

Brackenfern

Pleridium aquilinum

Bromegrass snooth

Bromus inermis

Bursoge, woollyleaf

Franseria tomentosa

Canangress, reed

Phalaris arundinacea

Cattail

Typha spo.

Clover, red

Trifolium pratense

Cover, white

Trifolium repens

Cogongrass

Imperata cylindrica

Dalliseras

Paspalum dilatatum

Dandelion

Taraxacum officinale

Dock, curty

Rumex crispus

Doptane, hemp

Apocynum cannabinum

Pescues

Festuea SpD.

Fesere, bill

Festuca arundinaces

Guineagrass

Pancium maximum

Horsenettle

Solanum carolinense

Horseradish

Amoracia rusticana

- Partial control

Nialia - Apply 1 quart of this product in 3 to 10 gallons of water per acre. Make application after last hay cut. ting in the fall. Allow alfalfa to regrow to a height of 6 to 8 inches or more prior to treatment. Applications should be followed with deep tillage at least 7 days ahter treatment. but before soil freeze-up.

Aligatorweed - Apply 4 quarts of this product pes acre or apply a $1.1 / 2$ percent solution with hand-held equipment to provide partial control. Apply when most of the plants are in bloom. Repeat applieations will be required to maintain such control.

Benterass - For suppression in grass seed production areas. For ground applications only. apply 1.5 quarts of this product in 10 to 20 zallons of water pes acre. Ensure entire crown area has resumed growth prior to a fall application. Bentgrass should have at least 3 inches of growth. Tillage prior to treatment should be aroided. Tillage 7 to 10 days after application is recommended for best results. Failure to use tillage after treatment may result in unacceptable control.

Bermudagras - For control, apply 5 quarts of this product per acre and, for partial control, apply 3 quarts per acre. Treat when bermudagrass is actively growing and seedheads are present. Retreatment may be neces sany to maintain control. Nlow 7 or more days after application before tillage.

Bermedaprases, water (tunoturase)-Apply 1.5 quaris of this product in 5 to 10 gallons of water per acce. Apply when water bermudagrass is actively growing and 12 to 18 inches in length. Allow 7 a more days before tilling. ftushing or flooding the field.

Fall applieations canj-Apply 1 quart of this product in 5 to 10 gallons of water per acre. Fallow fields should be tilled prior to applieation. Apply prior to frost on water bermudagrass that is actively growing and 12 to 18 inches in Jength. Aliow 7 or more days before tillage.

Bindweed, field-for control, apply 4 to 5 quarts of this product per acre west of the Mississippi River and 3 to 4 quarts east of the Mississippi River. Apply when the weeds are actively growing and are at or beyond full bloom. Do not treat when weed is under drought stress as good soil moisture is necessony for active growth. For best results, apply in late summer or fall. Fall treatments must be applied before a killing frost. Allow 7 or more days after application before tillage.

Nso for control, apply 2 quarts of this product plus 0.5 pound ai of Barived in 10 to 20 gallons of water per acre. At these rates, apply using ground applieation only.

The following tank mixtures with 2.4 .0 may be applied using aerial application equipment in fallow and reduced tillage systems only.

For suppression on irrigated agricultural land apply 1 to 2 quarts of this product plus 1 pound a.i. of 2.40 in 10 to 20 gallons of water per acre with ground equipment only. Applications should be made following havest of on tall ballow ground when the bindweed is actively grow ing and the majority of nunners are 12 inehes or more in length. The use of at least one irrigation will promole active bindweed growth.

For suppression, apply 16 fluid ounces of this product plus 0.5 pounds a.i. of 2.40 in 3 to 10 eallons of water per acre for ground applications and 3 to 5 gallons of wrtes per acre for serial applications. Applications should be delayed until maximum emerzence has cocumed and when vines are between 6 to 18 inches in length.

Bluouras Rentuch / Bromegress, suocth / Oreharderses - Apply 2 quarts of this product in 10 to 40 gallons of water per acre when the grasses are actively growing and most plants have reached boot.to-arly seedhead stage of development. For partial control in pasture or hay crop renoration, apply 1 to $1-1 / 2$ quarts of this product in 5 to 10 ealions of water per acre.

Apply to actively growing plants when most have reached 4 to 12 inches in height. Nlow 7 or more das atter application before tillage. 
Bluewed, Terss-Apphy 4 to 5 quarts of this product per acre west of the Mississippi River and 3 to 4 quarts per acre east of the Mississippi River. Apply when weed is actively growing and is at or beyond full bloom. Do not treat when weed is under drought stress as good soil moisture is necessary for active growth. New leal develop. ment indicates active growth. For best results, apply in bte summer of fall. Fall treatments must be applied before a killing frost. Nlow 7 o more days after application before tillage.

Bractentern - Apphy 3 to 4 quarts of this product per acse as a broadcast spray or as a 1 to 1-1/2 percent solution with hano-held equipment. Apphy to fully expanded fronds which are at least 18 inches long.

Burage, wrollylesf - For control, apply 2 quarts of this product plus I pint of Bannel per acte. For partial control, apply I quart of this product plus I pint of Banvel per acre. Apply 3 to 20 zallons of water per acre. Apply when plants are producing new active growth which has been initiated by moisture for at least 2 weeks and when plants are at $\propto$ beyond flowering.

Conmerase reed / Timothy / Wherterses, wetern Apply 2 to 3 quarts of this product per acre. For best results, apply to actively growing plants when most have resched the boot-tohead stage of growth. Allow 7 of more days after application before tillage.

Cogongress - Apply 3 to 5 quarts of this product in 10 to 40 zallons of water per acre. Apply when cogongrass is at least 18 inches tall and actively growing in late summer or fall. Allow 7 or more dass after applieation before tillage or mowing. Due to uneven stages of growth and the dense nature of vegetation preventing good spray coverage, repeat treatments may be necessan to mairtain control.

Dandelion/Doct, cort)-Apphy 3 to 5 quarts of this product per acre when plants are actively growing and most have reached the earty bud stage of growth. Allow 7 or more days after application before tillage.

Also for control, apply 16 fluid ounces of this product plus 0.5 pounds $2 . \mathrm{L} 2.40$ plus 0.5 to 1 percent nonionic surfactant by total spray volume in 3 to 10 gallons of water per acre.

Doptane, hemp-Apply \& quarts of this producd per acre. Apply when astively growing and when most weeds have reached the bite bud to flower stage of growth. Following crop havest ox mowing. allow weeds to regrow to a mature stage prior to treatment. For best results, apphy in late summer or fall. Alow 7 or more dass after appli. cation before tillage.

For suppression, apply 16 fluid ounces of this product plus 0.5 pound a.i of $2,4-0$ plus 0.5 to 1 percent nonianic surfactant by total spray volume in 3 to 10 gallans of wates per acre for ground applications and 3 to 5 gat bons of water per acre for aerial applications. Delay applications until maximum emergence of dogbane has cecurred.

Fescue thll - Apply 3 quarts of this product in 10 to 40 pallons of water per sece to actively growing plants when moss have reached boot-toearty seedhead stage of devet opment.

Fall applications only - Apply 1 quart of this product in 3 to 10 gallons of water per acre. Apply to fescue in the tall when activel growing and plants have 6 to 12 inches of new growth. Nlow 7 a more dass after application be fore tillage A sequential applieation of 1 pint per acre - of this product will improve lang-term control and con- trol seedlings germinating after fall trestments or the following spring.

Guinearras - Apply 3 quarts of this product per acre or use a 1 percent solution with handheld equipment. Apply to actively growing zuineagrass when most have reached at least the 7teaf stage of growth. Ensure thorough coverage when using hand-held equipment. Allow 7 or more days atter application before tillage.

Jahneongras / Rieares, pereanial - Apply 1 to 3 quarts of this product per acre In annul cropping sstems, apply 1 to 2 quarts of this product per acre. Apply I quart of this product in 3 to 10 eallons of water per acre. Use 2 quarts of this product when apphing 10 to 10 gallans of water per acre. In nonerop or areas where annual titbge (no-till) is not performed, apply 2 to 3 quarts of this product in 10 to 40 galions of water pes aere. For best results, apply to actively growing plants when most have reached the boot-to-head sage of growth. Alow 7 a more days a fter application before tillage. Do not tank. mix with residual herbicides when using the l quart per acre rate.

For burndown of johnsongrase, apply I pint pes acre in 3 to 10 gallons of water pes acre before the phants reach a height of 12 inches. For this use, alow at least 3 days atter treatment before tilloge.

Spot Treatment (partial control a suppression) - Apply a 1 percent solution of this product when johnsongrass is 12 to 18 inches in height Covenge should be uniform and complete.

Kikupueses - Apply 2 to 3 quarts of this product per acre. Spray when most kikupugrass is at least 8 inches in height ( 3 or 4 teaf stage of growth) and activety prow. ing. Allow 3 or more das after application before tillage

Knapweed/Alorsendsh-Apphy 4 quats of this product per acse. Apply when actinely growing and when most weeds have reached the late bud to flowes stage of growth. Following crop havest a mowine, allow weeds to regrow to a mature stage prior to treatment for best results, apphy in bite summer a tall Albow 7 a more dass after application before tilkge.

Unton - Apply this product es a 1 to $1-1 / 4$ percent so lution using hand held equipment andy. Apphy to activety growing lantans at $\alpha$ begond the bloom stage of growth. Use the higher application rate for plants that have reached the woody stage of erowth. Nlow 7 a more das after application betore tillage.

Millowed, commen - Apply 3 quarts of this product per acre Appty when actively growing and mass of the mill weed has reached the late bud to flower stape of growth. Following small gain hanato a mowine, allow milkweed to regrow to a mature stape prior to treatment. Niow 7 a more dass after applieation before tillage.

Wuhh, wiretem - Apphy 1 to 2 quarts of this product pes acre. Use 1 quart of this product in 3 to 10 calions of water per acre. Use 2 quarts of this product when apptying 10 to 10 eallows of weter pes ecre $\alpha$ in pasture, sod, ar noncrop areas Sproy when the wirestem munhy is 8 inches or more in heidtt and actived growine Do nat till between hamest and fall applieations $\alpha$ in the fall a spring prior to spring applieations. Alow 3 or more dess after appliction before tillage This product will nat provide residual control of wirestem muhly from seeds which germinate after a Rule hebicide application Do not tank mix with residual herbicides whes using the 1 quart pes acre rate.
Nightshade, silverteat - For control, apply 2 quarts of this product in 3 to 10 gallons of water pes acre. Applications should be made when at least 60 percent of plants have berries. Fall treatments must be applied be fore a killing frost. Allow 7 or more days after application before tillage. Do not treat when weed is under drought stress, as good soil moisture is necessary for active growth.

Nutsedge purple, yellow - Apply 3 quarts of this product per acre as a breadeast spray, or apply a 2 percent solution from hand-held equipment to control existing nutsedge plants and immature nutlets attached to treated plants Treat when plants are in flowe $a$ when new nutlets an be found at inizome tips Nutiets which hrue not germinated will not be controlled and may ger. minate following treatment. Repeat treatments will be required for long-term control of ungerminated tubers. Sequential applications of 1 to 2 quarts of this product in 3 to 10 ealions of water pes acre will provide control. Make applications when a majority of the plants are in the 3 to 5 leaf stage (less than 6 inches tall). Repert this application, as necessy, when newly emerging plants rech the 3 to 5 leaf stape. Subsequent applications will be neceseary for long-term control.

For suppression of existing plants, apply 1 pint to 2 quarts of this product in 3 to 40 gallons of water per acre Treat when plants have 3 to 5 leaves and most are less than 6 inches tall. Repeat treatments will be required to control subsequent emerging plants of regrowth of existing plants. Wait 7 days after treatement before tillage of mowing.

Pampss - Apply this product as a 1-1/2 to 2 pereent alution using handheld equipment Apply to plants that are actively growing at $\alpha$ bejond the boot stage of elow th. Therough coverage is neceseng for best control. Ptragnites - for partial control of phragmites in florida and the counties of other states bordering the Gulf of Mexico, apply 5 quarts per acre as a broadcast spray or apply a 2 percent solution from hand-held equipment. In othes areas of the U.S. apply 3 quarts per acre as a broadcast sproy ox apply a l percent solution from thandheld equipment for partial contro. For best results, treat during bte summes of fall months $\alpha$ when plants are actively growing and in full bloam. Treatment before or atter this stage my lead to redueed control. Due to the dense nature of the regetation, which mag prevent good sproy coverage $\alpha$ uneren stages of growth, repert treatments moy be necescory to maintria contod Visual control smptom will be slow to deretop.

Quachoras - In Aanal Croppias Ssterses or in Peteres and Sods Followed by Deep Tribre Ap phy I to 2 quarts of this product per acre for the one quart rate. apphy in 3 to 10 gallons of water per scre for the 2 quart rete, apply in 10 to 10 callons of water pes acre. Do not unk mix with residual herbicides when waing the I quart rete Sory when quackgrass is 8 to 12 inches in height and actively growing. Do not till between hanest and tall applications of in tall ox spring prios to spring application Allow 3 or more days after application before tillage in pastures or sods, for best results use a moldboard plow.

Cuncharas - Pature or Sod or Othes Nenerop Nress There onep Thage is flot Plannd Followiag Appiction Appty 2 to 3 quarts in 10 to 10 zalions of water per acre. Sprey when the quackeress is greater than 8 inches bll and activefy growine. Do not till betwees hanest and fall application o in tall a spring prior to spring application. Niow 3 or more doys after application before tillage. 
Rectrine-for suppressian, apply 24 fluid ounces of this product per acre at each of two applications 7 to 14 days apart or a single applieation of 2 quarts per acre. Apply recommended rates in 5 to 10 gallons of water per acre. Apply to actively growing plants in late September or early October, which are at least 18 inches tall and have been growing 45 to 60 days since the last tillage operation. Make applications at least one week before a killing frost.

Reed, giant - For control of giant reed, apply a 2 percent solution of this product when plants are actively arowing. Best results are obtained when applications are made in late summer to fall.

Smartwed, scamp-Apply 3 to 5 quarts of this product per acre when plants are actively growing and most have reached the early bud stage of growth. Allow 7 or more days after applieation before tillage.

Aso for control, apply 36 fluid ounces of this product plus 0.5 pound active ingredient of $2,4-\mathrm{D}$ in 3 to $10 \mathrm{gal}$. lons of water per acre in the late summer or tall. Apply when plants are actively growing and most have reached the earty bud stage of erowth. Nlow 7 a more days after apolication before tillage.

Spurze, leaty - For suppression, apply 16 fluid ounces of this product plus 0.5 pound active ingredient 2.4-0 in 3 to 10 gallons of water per acre in the late summer of fall. Apply when plants are actively growing. If mow. ing has occurred prior to treatment apply when most of the plants are 12 inches tall. Allow 7 or more days after applieation before tillage.

Sweet Potato, wild - Apply this product as a 2 percent solution using hand-held equipment Apply to actively growing weeds that are at or beyond the bloom stage of growth. Repeat applications will be required. Allow the plant to reach the recommended stage of growth before retreatment. Allow 7 or more days before tillage.

Thistle Canada - Apply 2 to 3 quarts of this product per acre. Apply to actively growing thistles when most are at $\alpha$ beyond the bud stage of growth. After harrest. mow. ing or tillage in the late summer or fall. allow at least 4 weeks for initiation of active growth and rosette derelopment prior to the application of this product. Fall treatments must be applied before a killing frost. Allow 3 os more dass after application before tillage.

For suppression of Canada thistle, apply I quart of this product. or 1 pint of this product plus 0.5 pound a.i. 2.4- , in 3 to 10 gallons of water per acre in the late summes or fall after havest, mowing or tillage. Nlow rosette regrowth to a minimum of 6 inches in diameter before treating. Applications can be made as long as leaves are still green and plants are actively growing at the time of applieation. Allow 3 or more dass atter applip. cation before tillage.

Terpedograss - Apply 4 to 5 quarts of this product pep acre to provide partial control of torpedograss Apply to actively growing torpedograss when most plants are at or beyond the seedhead stage of growth. Repeat applications will be required to maintain control. Fall treatments must be applied before frost Nlow 7 or more dass after application before tillage.

Trumpetereeper - For control, apply 2 quarts of this product in 5 to 10 gallons of water per acre. Apply in late September or October to actively growing plants which are at least 18 inches tall and have been growing 45 to 60 days since the last tillage operation. Make applica. tions at least \& week before a killing frost.

Other perenniats fisted on this labed - Apply 3 to 5 quarts of this product per acre. Apply when actively growing and most have reached early head or early bud staze of growth. Allow 7 or more days after application belore tillate.

\section{HOODY BRUSH AND TREES}

When applied as recommended under the conditions described. this product CONTROLS \& PARTIALLY CONTROLS the following woody brush, plants and trees:

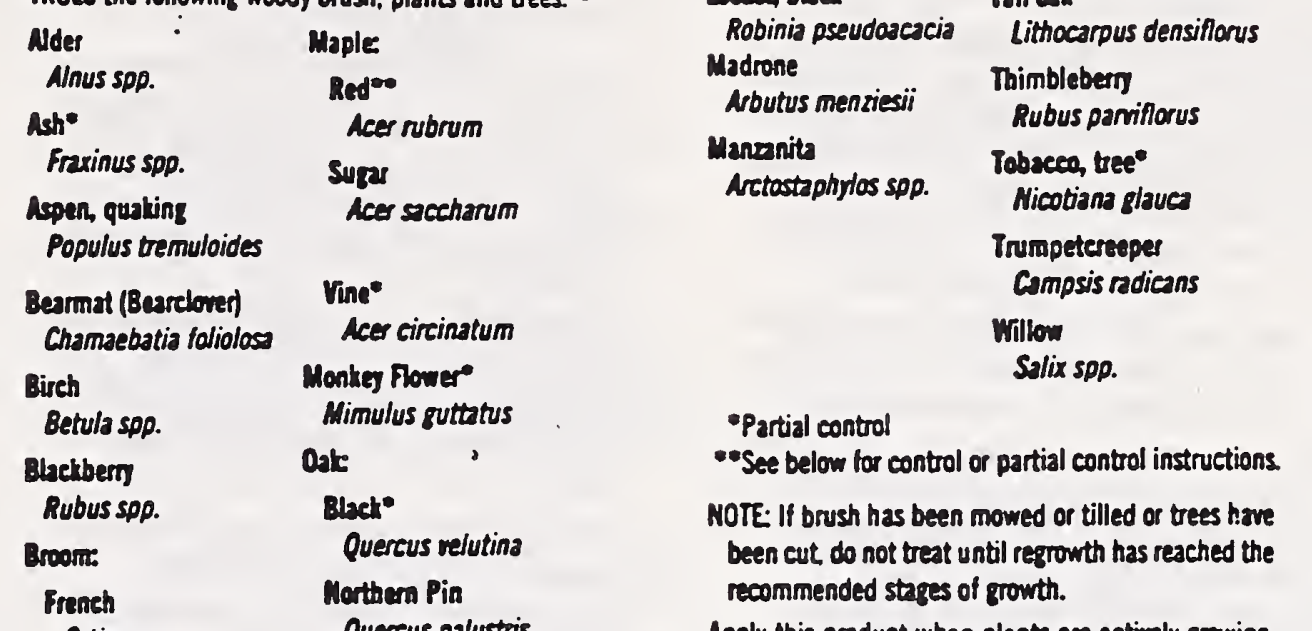

Apply this product when plants are actively growing. and unless otherwise directed. after full leaf expansion. Use the higher rate for larger plants and/or dense areas of grouth. On vines use the higher rate for plants that have reached the woody stage of growth. Best results are obtained when application is made in late summer or fall after fruit formation.

In arid areas best results are obtained when application is made in the spring to early summer when brush species are at high moisture content and are flowering. Ensure thorough. coverage when using hand-held equipment Symptoms may not appear prior to frost or senescence with fall treatments

Allow 7 a more days after applieation before tillaze. mowing a removal. Repeat treatments may be necessary to control plants regenerating from underground parts or seed. Some auturnn colars on undesirable deciduous species are acceptable provided no major leaf drop has oecurred. Reduced performance may result if fall treatments are made following a frost.

Apply this product as follows to contul or partially contol the following woody brush and trees.

Nder / Dembern / Hong suetle / Peat Oat / Rasp. bury - For control, apply 3 to 4 quarts per acer of this product as a broadeast sproy or as a 1 o $1.1 / 2$ percent solution with hand held equipment.

Eepen quating / Chem, bitter, blach, pin / Howthom / Oak, serthen red / Swetgum / Trumpetereeper For control, appty 2 to 3 quarts of this product per acre as a broadeast spray of as a 1 to $1.1 / 2$ percent solution with hand-held equipment.

Dirch / Ederbern / Haxd / Salmenben / Thimble bery - For control, apply 2 quarts per acre of this product as a brosdcast spray or as a I percent solution with hand-held equipment.

Llactbery - For control, apply 3 to 4 quarts per acre of this product as a broadcast spray, of 1 to $1-1 / 2$ percent solution with hand-held equipment. Make application after plants have reached full leaf maturity. Best results are obtrined when applications are made in late summer o fall Ature berries have set or dropped in late fall, blackberty can be controlled by applying a 3/4 
percent solution of this product with hand-held equipment. For control of blackberries after leaf drop and until killing frost or as long as stems are green. apply 3 to 4 quarts of this product in 10 to 40 gallons of water per acre.

Broom: French, Scotch - For control, apply a 1-1/2 to 2 percent solution with hand-held equipment.

Bucdwhest, Californis / Hasardia / Monkey Flower / Tobacco, tree - For partial control of these species. apply a 1 to 2 percent solution of this product as a folias spray with hand-held equipment. Thorough coverage of foliage is necessang for best results.

Catsclaw - For partial control, apply as a 1 to $1-1 / 2$ percent solution with hand-held equipment.

Cosote Brush - For control, apply a 1-1/2 to 2 percent solution with hand-held equipment when at leas 50 percent of the new leaves are fully developed.

Eucatypter bluezum - For control of eucalyptus resprouts. apply a 2 percent solution of this product with hand.held equipment when resprouts are 6 to 12 feet tall. Ensure complete coverage. Apply when plants are growing actively. Aroid application to drought-stressed plants. For control of eucalyptus trees 2 inches or less in diameter, cut trees as close to the soil surface as desired. Apply a 50 to 100 percent solution of this product to the freshly cut surface immediately after cutting. Delay in apphing this product may result in reduced pertormance.

Kudus - For control. spply 4 quarts of this product pes acre as a broadast spray or as a 2 percent solution with hand-held equipment Repeat applications will be it quired to maintain control.

Madrone respreats - For suppression or partial control, apply 2 percent solution of this product to resprouts less than 3 to 6 feet tall. Best results are obtained with spring/ earty summer treatments.

Maple ned - For control, apply as a I to I - 1/2 percent solution with hand-held equipment when at least 50 percent of the new lenes are fully developed. For partial control, apply 2 to 4 quarts of this product per acre as a braadcast spray.

Maple, wont / Oak, nerthem pin / Oak, red - For control, apply as a 1 to 1-1/2 percent solution with handheld equipment when at least $\mathbf{5 0}$ percent of the new leaves se fully dertioped.

Pcion ho / Paim Cad - for contrd, apphy 4 to 5 quats of this product per acre as a broadcast spray or as a 2 percent solution with handheld equipment. Repent ap. plications mos be required to maintain contro. Fall trentments must be applied before leaves lose green color.

Rese, multiflore - For control, apply 2 quarts of this product per acre as a broadcast spray or as a I percent solution with handheld equipment Treatments should be made prior to leal deterioration by leaffeeding insects.

Sage, bleck / Sagebrech, Califonia / Chanise / Tallow. tree, Chinesa - For control of these species, apply a I percent solution of this product as a foliar spray with hand-held equipment. Thorough coverage of foliage is neceseary for best results.

Taa eak respreuts - For suppression or partial controd, spply a 2 percent solution of this product to resprouts less than 3 to 6 feet tall. Best results are obtained with spring/early summer treatments.

ritiou - For controd, apply 3 quarts of this product pes acre as a breadeast sproy or as a I percent solution with hand-held equipment.

Other Hoody Brush and Trees listed an this labet - For partial control, apply 2 to 4 quarts of this product pes acre as a broadeast spray $\alpha$ as a 1 to $1-1 / 2$ percent solution with hand-held equipment.

\section{NONCROP USES}

See "General Information" and "Mixine, Additives and Application Instructions" sections of this label for essential product performance intormation and the following "Nonerop" sections for speeific recommended uses

EXTREME CARE MUST BE EXERCISED TO AYOID CONTACT OF SPRAY WITH FOLLAGE OF DESIRABLE TURF. GRASSES. TREES, SHRUBS, OR OTHER DESIRABLE VEGETATION SINCE SEVERE DAMAGE OR DESTRUC TION MAY RESULT.

Repeat treatments my be necessan to control weeds regenerating from underground parts or seects

This product does not provide residual weed control. for subsequent weed control, fallow a labe-approved herbicide program.

Read and carefully obsene the cautionary statements and all other information appearing on the labels of all herbicides used.

\section{FARMSTEAD WEED CONTROL}

When applied as directed for "Nancrop Uses", under conditions described, this product controts undesirable vegetation listed on this label around farmastead building foundations, along and in fences, shetterbetts, and for general nonselective farmstead weed control.

For specific rates of application and instructions for control of various annual and perennial weects, see the "Feeds Controlled" section of this tabel.

\begin{tabular}{|c|}
\hline $\begin{array}{l}\text { GRASSES FOR } \\
\text { SEED PRODUCTION }\end{array}$ \\
\hline $\begin{array}{l}\text { PREPLANT AMD REMOYATION } \\
\text { When applied as directed for "Noncrop" uses under } \\
\text { eonditions described, this product coptrols most } \\
\text { eristing mpetation prior to the planting or renowation } \\
\text { of grass seed production areas }\end{array}$ \\
\hline
\end{tabular}

for specific rates of appliantion and instructions for control of various annual and perennial weets. and wooty brush and trees, see the "Weeds Contodled" section of this label.

For maximum contol of existine rectution, dely planto ing to determine if any resrowth from excaped under. sround plant parts occurs. Where repant trentments are necesary, sufficient regrowth must be thined prior to application. for wam-seasen maves, such as bermuder erass, summes or fall applications provide best control. DO NOT DISTURB SOIL OR UNOERGROUND PUNT PARTS BEFORE TREATMENT. Tulure ar renoration techniques such as vertical mowine coring a dicing should be delayed for 7 dass after application to allow propes translocation into undereround plant parts.

Appty this product to activety growing weeds it the stares of growth given in the "Weeds Controlied" section of this label prior to planting or renowation of turf or torage grass areas grown for seed production.

DO NOT feed or grue treated areas within 8 weeks after application.

\section{CROPPING SYSTEMS}

When applied as directed for "Cropping Systerns", under the conditions described, this product controls annual and perennial weeds listed on this label, prior to the emerzence of direct seeded crops or prior to transplanting of crops listed on this label.

See the "General Information" and "Mixing, Noditives and Application Instruetions" sections of this label for escential product performance information.

DXTREME CARE MUST BE EXERCISED TO AVOID CONTACT OF SPRAY WITH FOLLAGE, GREEN STEMS OR FRUIT OF OESIRABLE CROPS, PLANTS, TREES OR OTHER DESIRABLE VEGETATION SINCE SEVERE OAMAGE OR DESTRUCTION MAY RESULT.

Repeat treatments may be necesery to control weeds regenerating from underground parts or seed. Except as othervise specified on this bibel, repert treatments must be mede before the crop eneres in cocordance with the instructions of this label.

Ercept as otherwise specified in a crop section of this label, the combined total of all treatments must not ex. ceed 8 quarts per acre of this product per year.

Do not plant subsequent crops other than those on the buel for 30 days following application.

Do not barvest or feed treated regetation for 8 weets for boming application Following spot treatment $\alpha$ selective equipment use, allow 14 days before grasing domestic livestock or havesting forage grasses and legumes.

\begin{tabular}{|c|c|}
\hline NFNFA* & LOGAHBERRY \\
\hline ARTICHOKE & LOHGAK \\
\hline (Jenisalem) & LYCHEE \\
\hline ISPARAGUS* & MELONS"* \\
\hline ATEMOYA & MUSTARD GREEHS \\
\hline BARLEY* & OATS \\
\hline BENSS (NII & OKRA \\
\hline BEET GREEHS & OLUULEBERRY \\
\hline BEETS (Red, Sugar) & OHION \\
\hline BUACBERRY . & PARSHIPS \\
\hline BUESBERRY & PLSSIOK FRUTT \\
\hline DOTSENBERRY & PENUTS \\
\hline BRENOFRUT & PEAS (NII) \\
\hline BRoceol] & PEPPER \\
\hline CABBNGE & PERSIMMONS \\
\hline CANISTEL & PINEAPPLET \\
\hline CARAMBOLA & POTATO (Irish, Sweet) \\
\hline CARROT & PUМPKIK*** \\
\hline CNUUROHER & RDISH \\
\hline CEIERY & RISPBERRY \\
\hline CHICORY & (Black, Red) \\
\hline CORN (NI)* & RICE* \\
\hline COTTON* & RUTABAGA \\
\hline CRAHBERRY & SAPODILA \\
\hline $\begin{array}{l}\text { CUCUMBER } \\
\text { CURRAMT }\end{array}$ & $\begin{array}{l}\text { SAPOTE (Black, } \\
\text { Mamey, White) }\end{array}$ \\
\hline OATES & SORGHUH (Milo) \\
\hline DEWBERRY & SOURSOP \\
\hline
\end{tabular}




\begin{tabular}{|c|c|}
\hline EGGPLANT"* & SOYBEANS" \\
\hline ELDERBERRY & SPINACH \\
\hline FORAGE GRASSES & SQURSH $= \pm$ \\
\hline FORAGE LEGUMES" & (Summer, Winter \\
\hline GARLIC $\cdots$ & SUGAR APPLE \\
\hline GOOSEBERRY & SUGARCANE \\
\hline GOURDS" & TAMARIND \\
\hline HORSERADISH & TOMATILLO"Е. \\
\hline HUCKLEBERRY & TOMATOES $* * * \dagger$ \\
\hline JABOTICABA & TURNIPS \\
\hline JACKFRUIT & WATERCRESS * \\
\hline KALE & WATERMELON** \\
\hline LENTILS & WHEAT \\
\hline LETUCE & YAMS \\
\hline
\end{tabular}

- Spot treatments may be applied in these crops.

- Do not treat rice fields or levees when the fields contain Hood water.

- Apply only prior to planting. Allow at least 3 days between applieation and planting.

fUse is restricted to direct seeded crops only.

ttoo not feed or graze treated pineapple forage follow. ing application.

When applying this product prior to transplanting erops into plastic mulch. care must be taken to remove residues of this product from the plastic prior to transplanting. Residues can be removed by $h$ inch natural rainfall or by applying water via a sprinkler irrization system.

Spot Treatment (Only those crops with mam can be spot treated) - Applications in growing crops must be made prior to heading of small grains and milo, initial pod set in soybeans, silking of corn, or boll opening on cotton.

For forage grasses and forage legumes. see the "Spot Treatment" in the "Pastures" section of "Cropping Systems" in this label.

For dilution and rates of application using boom or handheld equipment. see the "Mixing. Additives and Application Instructions" and "Weeds Controlled" sections of this label.

NOTE: FOR FORAGE GRASSES AND FORAGE LEGUMES, NO MORE THAN ONE.TENTH OF ANY ACRE SHOULD BE TREATED AT ONE TIME. FOR ALL OTHER CROPS. DO NOT TREAT MORE THAN 10 PERCENT OF THE TOTAL FIELD AREA TO BE HARVESTED.

THE CROP RECEIVING SPRAY IN TREATED AREA WIL BE KILLED. TAKE CARE TO AVOID DRIFT OR SPRAY OUTSIDE TARGET AREA FOR THE SAME REASON.

Selective Equipment - This product may be applied through recirculating sprayers, shielded applicators, of wiper applicators in cotton and soybeans. Shielded and wiper applicators may also be used in tree crops and grapes. Wiper applicators may be used in rutboagas. forage grasses and forage legumes, including pasture sites and grain sorghum (milo).

See the "Selective Equipment" part of the "Application Equipment and Techniques" section of this label for information on proper use and calibration of this equipment.

Allow at least the following time intervals between application and harvest.

Cotton. Soybeans $\ldots \ldots \ldots \ldots \ldots \ldots \ldots 7$ days Apples. Atemoy, Avocado, Breadfruit. Canistel,
Carambola, Cherry, Citrus, Dates, Grapes. Jaboticaba. Jackfruit, Longan, Lychee, Passion Fruit, Pear, Persimmons, Rutabagas, Sapodilla. Sapote, Soursop. Sugar apple. Jamarind. . . 14 days Stone Fruit ....................17 days Nut Crops .....................21 days Sorghum (milo) $\ldots . \ldots \ldots \ldots \ldots \ldots .40$ days

-Do not use roller applicators Do not feed or graze treated milo fodder. Do not ensile treated vegatation.

\section{ASPARAGUS}

When applied as directed for "Cropping Systems", under the conditions described, this product controts weeds listed on this label in asparagus

For specific rates of application and instructions for control of various annual and perennial weeds, see the "Weeds Controlled" seetion of this label.

Prior to Crop Energence - Apply this product prior to planting or emergence of spears in an estab.ished crop for the control of emerged labeled annual and perennial weeds. DO NOT APPLY WITHIN A WEEK BEFORE THE FIRST SPEARS EMERGE.

Spot Irestment - Apply this product immediately after cutting. but prior to the energence of new spears Do not treat more than 10 percent of the total field to be harvested. Do not havest within 5 days of treatment.

- Pesthamax-Apply this product after the las havest and all spears have been removed. If spears are allowed to regrow. delay applieation until ferns have developed. Delayed treatments should be applied as directed or shielded spray in ordes to aroid contact of the soray with ferns, stems or spears. Direct contact of the spray with the asparaqus may result in serious crop injury.

NOTE: Select and use recommended types of spray equipment for postemergence postharvest applications A directed spray is amy applicaton where the spray pattern is alizned in such a way as to avoid direct contact of the spray with the crop. A shielded spray is any application where a physical barrier is positioned and maintained between the soray and the crop to prevent contact of the spray with the crop.

\section{BERRIES AND SMALL FRUIT}

For cranberies, apply after fruit set and no later than 30 days before hanest

Wiper applieators may be used in cranberries in accordance with instructions in this section.

For other berries. apply as a preplant broadcas? application. or as a directed spray or wiper application post-planting.

See the "General Information" and "Mixinz. Acditives and Application Instructions" sections of this Iabel for essential product performance information.

See the "Selective Equipment" part of the "Apolication Equipment and Techniques" section of this label for information on reconimended use and calibraton of this equipment

For Wiech or other Wiper Applieaters - Mix i gallen of this product in 4 gallons of water to prepare a 20 percent solution. Apply the solution to emerged wseds Apply after cranberry fruit set and no later than 30 days before harvest

In severe infestations, reduce equipment ground speed to insure that adequate amounts of this product are wiped on the weeds. A second treatment in the opposite direction may be beneficial.

Do not permit herbicide solution to contact desirable vegetation, including green shoots, canes, or foliaze.

\section{FALLOW AND REDUCED} TILLAGE SYSTEMS

Use this product in fallow and reduced tillage systems for control of annual weeds prior to emergence of crops listed in this label. Refer to the "Weeds Controlled" section of this label tor specific rates and instructions. This product may be applied using ground or aerial spray equipment. See the "Applieation Equipment and Techniques" section of this label for instructions.

TANK MIXTURES
RULER plus BANYEL
RULER plus 2,40
RULER plus GOAL"

Applications of 2.4.0 or Banvel must be made at least 7 days prior to planting corn. Applications of 2.4-Q must be made at least 30 days prior to planting soybeans.

The addition of Banvel in a mixture with this product may provide shart-term residual control of selected weed species. Some crop injury may occur if Banvel is applied within 45 days of planting. Refer to the Banvel and 2,4-D labels for cropping restrictions and other use instructions.

\section{Rulero plus Goal Tank Mixtures}

This product alone or in tank mixtures with Goal will provide control of those weeds listed below.

Make applications when weeds are actively growing and at the recommended stages of growth. Avoid spraying when weeds are subject to moisture stress, when dust is on the foliage or when straw canopy covers the weeds.

\begin{tabular}{|c|c|c|c|}
\hline \multicolumn{2}{|c|}{$\begin{array}{l}\text { RULER } \\
12 \text { fluid oz/acre }\end{array}$} & \multicolumn{2}{|c|}{$\begin{array}{l}\text { nuLER } \\
16 \text { fluid oz/acre }\end{array}$} \\
\hline $\begin{array}{l}\text { Wheat } \\
\text { Barley } \\
\text { Bluegrass. } \\
\text { annual } \\
\text { Barnyardgrass } \\
\text { Rye }\end{array}$ & $\begin{array}{l}18^{\prime \prime 0} \\
12^{\circ} \\
6^{\circ} \\
6^{\prime \prime} \\
6^{\prime \prime}\end{array}$ & $\begin{array}{l}\text { Annual grasses at } \\
\text { left plus: } \\
\text { Ryegrass. } \\
\text { annual } \\
\text { Chickweed } \\
\text { Groundsel } \\
\text { Marestail } \\
\text { Rocket. London } \\
\text { Shepherdspurse } \\
\text { Crabgrass } \\
\text { Johnsongrass, } \\
\text { seedling } \\
\text { Lambsquarters } \\
\text { Oats, wild } \\
\text { Pigweed, redroot } \\
\text { Mustards }\end{array}$ & $\begin{array}{c}6^{\prime \prime} \\
6^{\prime \prime} \\
6^{\prime \prime} \\
6^{\prime \prime} \\
6^{\prime \prime} \\
6^{\prime \prime} \\
12^{\prime \prime} \\
12^{\circ} \\
12^{\circ} \\
12^{\circ} \\
12^{\circ} \\
12^{\prime \prime}\end{array}$ \\
\hline
\end{tabular}

\begin{tabular}{|c|c|}
\hline $\begin{array}{c}\text { RULER } \\
12 \text { fluid az/acre } \\
+ \\
\text { conte- } \\
2104 \text { fluid az/acre }\end{array}$ & $\begin{array}{c}\text { RULER } \\
86 \text { fluid or/acre } \\
+ \\
\text { Conlo: } \\
2 \text { to } 4 \text { fluid az/acre }\end{array}$ \\
\hline $\begin{array}{l}\text { inual grasses above } \\
\text { us: } \\
\text { leeseweed }\end{array}$ & $\begin{array}{l}\text { Annual weeds above } \\
\text { plus: } \\
\text { Cheeseweed }\end{array}$ \\
\hline
\end{tabular}


RULER

12 fluid as/aere

$+$

GOAL".

16 fluid oz/acie

2 to 4 fluid az/acre

\begin{tabular}{llll}
\hline Chickweed & $3^{\prime \prime}$ & Groundsel & $6^{\prime \prime}$ \\
Groundsel & $3^{\prime \prime}$ & Chickweed & $6 "$ \\
Rocket, London & $6^{\prime \prime}$ & Rocket, London 12" \\
Shepherdspurse & $6^{\prime \prime}$ & Shepherdspurse & $12^{\prime \prime}$ \\
\hline
\end{tabular}

- Maximum height of length in inches.

- Use the higher rate when weeds approach maximum recommended height or stands are dense.

racoal is a trademart of Rohm and Hass Company.

\section{ECOFARMING STSTEMS}

The Ecotaming System consists of the following rotation: winter wheat, corn/sorghum, ecolallow.

Use the following tank mixtures for control of emerged annual weeds before planting corn or sorghum in the Ecofarming System.

RULER० at 16 to 20 fluid ounces per acre plus

2,40 at 0.375 to 0.5 pound a.i. per aere plus

ATRAZINE at 0.75 to I pound a.i. per acre plus

LSSO $^{\circ}$ at 2.5 to 3 quarts per acre

The above tank mixture should be applied in 28-0-0 or 32-0.0 liquirs fetilizes carrier at 20 to 30 zallons per acre.

The liquid fertilizer may be diluted with water to achiere the required carrier volume.

WEEDS CONTROLLED - The following weeds. uD to a maximum height of 4 inches, will be controlled:

Brome, down

Bromus tectorum

Cheat

Bromus seealinus

Lettuce, prickly

Lactuca serriola

Pisweed, redrout

Amaranthus retroflexus

Poxtail, green

Setaria viridis

Foxtuil, yellow

Setaria Jutescens

Thistle, Russian

Solsola kali

Wheat, relunteet

Triticum aestivum

Rochia*

Kachis scoparis

- For improved control of hochia. add 4 fuid ounces per acre ( 0.125 pound a.i. per acre) of Banvel to the above tank mixture.

Risk of crop injury from 2,4-D or Banvel can be reduced by applying this treatment 7 to 14 days belore plantine. Refer to the label booklet for Lasso herbicide for preemergence weed control achieved by this tank mixture.

Refer to the specific product labels for crop rotation restrictions and cautionary statements for all products used in these tank mixtures

- Lasoo is a requatered tradenarti of Mensonto Compam.

\section{AD TO TIUAGE}

This product, when used in conjunetion with preplant tillage practices, will provide control of downy brome, cheat, volunter wheat, tansy mustard and faxtail. Apphy 8 fluid ounces of this product in 3 to 10 eallons of water per acre. Make applications when weeds are actively growing and before they are 6 inches in height. Application must be followed by conventional tilloge practices no later than 15 dass after treatment and before regrowth occurs. Allow at least I day atter application before tillage. Tank mixtures with residual herbicides may result in reduced performance.

\section{PASTURES}

Apply this product prior to planting forage grases and lequmes.

Pasture or Hay Crop Renoration - When applied as a broadeast spray, this product controts the annual and pesennial weeds listed in this label prior to planting loraze grasses or legumes Remove domestic livestock before application and wait 8 weets after application before grazing or harvestine.

Spot Treatment - When applied as a spot treatment as recommended, this product controts annual and perennial weeds listed in this labet which are growing in pastures, forage grasses and forage lezumes composed of bahiagrass, bermudagnass, bluegrass, brome, fescue. orchardgrass, negrass, timothy, wheaterass, alfalia or clover.

Wiper Applieation - When applied as directed, this product controls or suppreses the weeds listed under "Wiper Applieators" in the "Selective Equipment" section of this babel.

For spot treatment and wiper application, apphy in areas where the morement of domestic linestock an be controlled. No more than one-tenth of any acre should be treated at one time. Further applications mo be made in the same area at 30-day intervats. Remove domestic livestock before application and wit 14 dass after applieation before arzing linestock or harvesting.

\section{SUGARCANE}

When applied as directed tor "Troppine Systerss", under the condition described, this product controts these emerged annual and perennial weeds listed on this label erowing in or around suzarcane or in fields to be planted to sugarcane. This product will also control undesirable sugarane.

NOTE: Where repeat treatments are necesany, do not exceed a total of 10.6 quarts of this product per acre per year. Do not apply to regetation in of around ditches canals or ponds containing water to be used for irrigation.

creadest Irentment - Apply this product in 10 to 40 callons of water pes core an emered weeds trowing in fields to be planted to surarane.

For specific rates of application and instructions for control of various annual and perennial weeds, see the "Weeds Cantrolled" section of this label.

For remoml of last stubble or retoon ane apphy 4 to 5 quarts of this product in 10 to 40 callons of water per care to new erowth hoving st lesst 7 or more now lenes. Nlow 7 or more dass aftes application before tillase.

Spot Ireatment in ex Aroud Sorreane Fidde-for dilution and rotes of application using hand-held equip. ment, see "Mixing, Additives and Application lastore. tions" and "Weeds Cantrolled" sections of this label.

for control of volunteer or diseased sparcane, make a 1 percent solution of this product in witer and spray to wet the foliage of rezetation to be controlled.

NUTE: When spraying rolunter of diseased supareane the plants should hrve at least 7 new lesves
Aroid sproy conted with healthy cane plants since serere damage or destruction may result

Do not feed o graze treated sugareane forage following application.

\section{CONSERVATION TILLAGE, MINIMUM TILLAGE AND NO-TILL SYSTEMS CORN AND SOYBEANS Tank Mixtures}

When applied as recommended under the conditions described, the tank mixtures listed in this section control many emerged weeds, and zive preemergence control of mamy annual weeds where corn or sopteans will be planted directly into a cover crop, established sod, of in previous crop residues.

Refer to specific product labels for crop rotation restrictions and cutionang statements of all products used in these tank mixtures. For mixing instructions, see the "Mixine Additives and Application Instructions" section of this label.

Apply these tank mixtures in 10 to 20 gallons of water a 10 to 60 gallons of nitrogen solutions per acre before. during of after plantine. Do not apply these mixtures after crop emergence.

The addition of 1 to 2 percent dry amrnonium sulfate by weight may increase the performance of this product. MOTE: When using these tank mixlures, do not exceed 4 quarts of this product pes acre.

CORN

For residual control, this product may be tank-mixed with the following herbicides or combination of herbicides:

$\begin{array}{ll}\text { USSOO/NLACHLOR } & \text { ATRLINE } \\ \text { URIATE } & \text { CYANAZINE } \\ \text { BUUTT } & \text { SIMAZINE } \\ \text { DUAL" } & \text { PROML" } \\ \text { BICEPI } & \end{array}$

for innored bumdom, this product may be tank-mixed with 2,40 or dicamba Apolications of 2,4-0 or dicamba must be made at least 7 das priox to planting corn. See the "Weeds Controlled" section lox specific rate information.

\section{SOYBEARS}

for residual control, this product mor be tank-mixed with the following herbicides or combination of herbicides cANOPY COMMUND" DUL" GEMINI

USSOO/NUCHLOR

LEXNE" UANURON LOROX PLUS PREVIEW PROML" TURBO SCEPTER" SENCOR" SQUADRON"

For inprowed burndown this product mar be tankmixed with the following herbicides

$$
\begin{aligned}
& 2,40 B \\
& 2,40^{\circ}
\end{aligned}
$$

- Applications of 2,40 must be made at least 30 dos prior to plantine soybeans See the "Weeds Controlled" section for specific nte information.

$$
\text { CORH ANO SOYBEANS }
$$

Anewd Wieds-for difficalt to control weeds such as tall panjerm, barmardinas, coabgrass, shottercane and croodleat signalgras up to 2 inches tall, and Pear sivanis smattweed up to 6 incties tall, appty this product It 2 pints per ace in these tank mixtures. For othes 
labeled annual weeds, apply 1 to 1.5 pints of this product per acre when weeds are less than 6 inches tall, and 2 to 3 pints when weeds are over 6 inches tall. For a cornplete list of annual weeds controlled, see the "Weeds Controlled" section of this label.

Perennial Weeds-At normal application times in minimum tillage systems, perennial weeds may not be at the proper stage of growth for control. See the "Weeds Controlled" section of this label for the proper stage of growth for perennial weeds.

Use of 2 to 4 quarts of this product per acre in the tank mixtures mentioned above, under these conditions pro vides top kill and reduces competition from many emerged perennial grass and broadleaf weeds. For emerged perennial weeds controlled, see the "Weeds Controlled" section of this label.

To obtain the desired stage of growth, it may be neces sary to apply this product alone in the late summer or fall and then follow with a labetapproved, seedling weed control program at planting.

USE OF THESE TANK MIXTURES FOR BERMUDAGRASS OR JOHNSONGRASS CONTROL IN MINIMUM TILLAGE SYSTEMS IS NOT RECOMMENOED. For bermudagrass control, follow the instructions under "Control of Peren. nial Weeds" section of this label and then use a label approved. seedling weed-control program in a minimum tillage or conventional tillage system. Fer johnsongrass control, follow instructions under "Control of Perennial Weeds" section of this label. and then use a tabel approved seedling weed control program with conven. tional tillage.

- Bullet and Larat are regratered tademarts of Monsanto Campany. Canopr. Bladex. Gemin. Lexone. Lorox Plus and Prenew are trademarts of E.l. duPont de Nemours and Company.

- Dual is a trademarh of Ciba-Geica Corooration.

- Sencer and Turbo are trademarts of Bare AC.

"Prowl. Sceoter and Squadron are trademarts of Ameriean Cranamid Company.

Command is a trademach of FMC Corporation.

\section{PREHARVEST APPLICATIONS}

COTTON

When applied as directed under the conditions described. this product controls annual and perennial weeds listed on this label prior to the harvest of cotton.

Breadeast Applications - This product may be applied using eithe aerial or ground spray equipment for ground applications with broadcast equipment, apply this product in 10 to 20 gallons of water per acre. For aerial applieations, apply this product in 3 to 10 gallons of water per acre.

FOR AERIAL APPLCANONS, REFER TO THE "APPLCA TION EQUIPMENT AMO TECHNIQUES" ANO "AERIAL EQUIPMENT" SECTIONS OF THIS UBEL

DO NOT EXCEED A MAXIMUM RATE OF I QUART PER ACRE OF THIS PRODUCT WHEN MAKING APPLICATIONS BY AIR.

Weed Control-For specific rates of application and instructions for control of various annual and pereanial weeds for this product used alone or in the following tank mixtures, see the "Weeds Controlled" section of this tabel.

To control ionnsongrass using multiple directed or broadcast over-the-top spray equipment, apply l quart of this produet in 10 to 20 gallons of water per acre. Ensure complete coverage.

For partial control of field bindweed. apply 1 quart of this product in 3 to 20 gallons of water pers acre. Apply when bindweed is actively growing and 12 inches or greater in length. Reduced performance may result if bindweed is under drought stress.

\section{Tank Mixtures}

RULERO plUS DEF" 6

RULER plUS FOLEX

RULER Dlus PREP

RULER plus PREP plLS DEF 6 o FOLEX

When applied as secommended under the conditions described, these tank mixtures control annual and perennial weeds listed on this label prior to the harvest of cotton. For application guidelines, precautions and userates, refer to the Def. Folex and Prep labels.

This product when tank mixed with Def 6 or Folex defol. iants may provide enhancement of cotton leaf drop and regrowth inhibition.

Timing of Application - Apply this product or these tank mixtures for preharvest weed control after 60 percent of the cotton bolls have opened.

NOTE: DO NOT APPLY TO CROPS GROWN FOR SEED.

Allow a minimum of 7 das between application and havest. Do not feed or graze treated cotton forage or hay following preharvest apolications.

Def is a tratemurt of Mobsy Chemical Comasn

Falex and Prep are tradenuxts of RhonePoulenc. lac.

\section{TREEAND VINE CROPS}

This product is recommended for weed control in established groves, vineyards, or orehards, or for site preparation prior to transplanting crops listed in this section. Applieations may be made with boom equipment. COA. shielded sprayers, hand-held and high-rolume wands. lances, or orchard guns, or with wiper applieator equipment, except as directed in this section. See the "Applieation Equipment and Techniques" section of this label for specific information on use of equipment.

When applying this product refer to the 'Weeds Controlled" section of this label and to specific recommendations in this section for rates to be used.

\section{NOTE}

Repeat treatrnents may be necessan to control weeds originating from underground parts of untreated weeds of from seeds. This product does not provide residual weed control. For subsequent weed control. use repeated applieations of this product Do not apply more than 10.6 quarts of this product per aere per year.

EXTREME CARE MUST BE EXERCISEO TO AVOIO CONTACT OF HERBICIOE SOLUTION, SPRAY, ORIFT. OR MIST WTH FOLIAGE OR GREEN BARK OF TRUNK, BRANCHES. SUCKERS. FRUIT. OR OTHER PARTS OF TREES OR VINES. CONTACT OF THIS PRODUCT WITH OTHER THLAN MATUREO BROWN BARK CAN RESULT IN SERIOUS CROP DAMAGE.

AVOIO PAINTING OUT STUMPS WITH THIS PROOUCT AS INJURY RESULTING FROM ROOT GRAFTING MAY OCCUR IN AOLACENT TREES.

Reduced control may result when applications are made to annual or perennial weeds that have been mowed. grazed or cut and have not been allowed to regrow to the recommended stage for treatment.

For specific rates of applications and instructions, see the "Weeds Controlled" section of this label, and to specific recommendations which follow.

\section{MIDOLES MAKAGEMEHT}

FOR ANNUAL WEEDS IN MIDDLES BETWEEN ROWS OF TREE AND VINE CROPS

For citrus crops treat uniformly between trees.

$$
\begin{aligned}
& \text { RULER } \\
& \text { RULER DlUS GOAL }
\end{aligned}
$$

This product alone or in mixtures with Gaal will control or suppress the annual weeds listed below.

Apply the recommended rates of this product, either alone or in mixtures with Goal, in 3 to 10 gallons of water per acre. Apply when weeds are actively growing and less than 6 inches in height or rosette diameter. If weeds are under drought stress, imigate prior to application. Reduced control may occur if weeds have been mowed prior to applieation. Up to 48 fluid ounces per acre of this product may be used to control weeds which have been mowed, are stressed, or are growing in dense copulations.

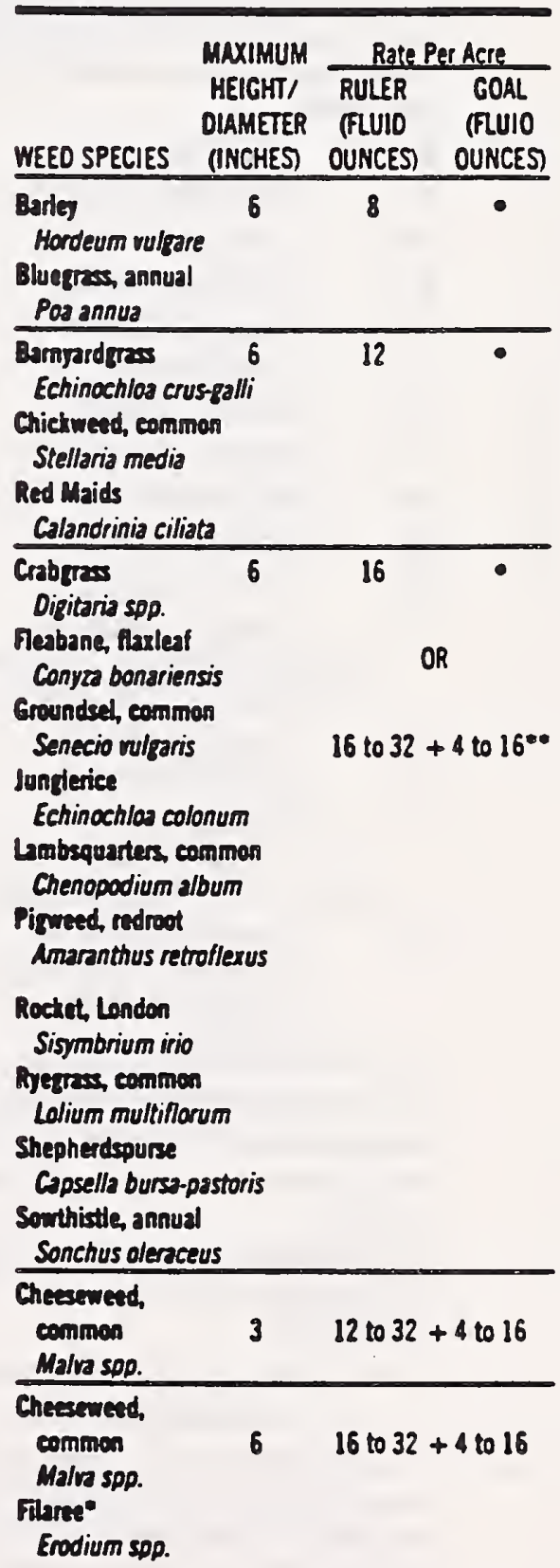


Horseweed/Marestail

Conyza canadensis

Hettle, stinging

Urtica dioica

Purselane, common*

Portulaca olesacea

- Suppression only

- The mixture of this product plus Gaal is recommended when weeds are stressed or growing in dense populations.

\section{STRIPS}

FOR ANNUAL AND PERENNIAL WEEDS IN STRIPS OF TREE AND VINE CROPS

\section{TANK MIXTURES}

WITH RESIDUAL HERBICIDES

When applied as a tank mixture, this product provides control of the emerged annual weeds and control or suppression of emerged perennial weeds listed in this label. The following residual herbicides will provide pre emergence control of those weeds tisted in the individual product labels.

RULER PlUS GOLL 3.65

RULER plas KARMEX" OF

RULER ples KROVAR I

RULER plus KROVAR II

RULER plUS SIMIZINE.

PRINCEP CULIBER" 90

RULER plLS SIMUZINE $4 L$

RULER plUS SIMNZIKE $80 \%$

RULER plus SOLJCAM" $800 F$

RULER plus SURFLA" is

RULER plus SURFUN 75W

RULER plas SIMRZIME

BOH, ON 4L O PRIHCEP CAUBER 90)

des SURFAN (AS or 75m)

RULER plus GOAL (1.69)

PlUS SURFAN (AS OF 75W

RULER plus GOAL (1.6B)

plus SIMAZIME

(EOW, or 4L, O PRINCEP CUUBER 9O)

RULER plus GONL (1.6E)

Dtes SURRAN US \& 75\%

plas SIMUZJME (BOW, 44,

O PRIMCEP CALIBER 90)

Do not apply these tank mixtures in Puerto Rico.

Refer to the individual product labels for specific crops. rates. zeographical restrictions and precautionary statements.

Read and carefully observe the label claims, cautionany satements. rates and all other information on the labels of all products.

Turmea is a tradenert of CL. duPent de Hemours and Compan.

\section{RECOMMENDED RATES}

Annual Weeds-Apply 1 to 5 quarts per acre of this product in these tank mixtures Use rates at the higher end of the recommended range when weeds are stresed. growing in dense populations or are greates than 12 inches tall.

Perennial Weeds-Apply 1 pint to 5 quarts pes acre of this product in these bak mixtures to control or suppress perennial weeds. Follow the recommendations in the "Weeds Controlled" section of this label for stage of growth and application rates for specific perennial weeds.

RULER plus GOAL
ples SIMRZINE/SURHAN

This product plus low rates of Goat in three-way or four. way mixtures with simazine and/or Surflan will provide postemergence control of the weeds listed below.

Refer to the individual simazine and Surtlan labels for preemergence rates, weeds controlied. precautionary statements and other important information.

Apply 1 to 5 quarts per acre of this product plus 4 to 48 fluid ounces per acre of Goal plus labeled rates of simzzine and/or Surlian in 3 to 40 gallons of water per acre to control the following weeds.

Batley, wild Hordeum leporinum

Bluegras, annual

Pos annua

Cheeseweed, common

Malva spp.

Chichweed, common

Stellaria media

Filaree

Erodium spp.

Fleabane, Aarleat

Conyza bonariensis

Horsemeed/Maretail

canpe canadensis

Nettle, stinging

Utrice divios

Pineappleweed

Matricari matricariodes

Rechte, Landen

Sismbrium irio

Shepherdopurse

Cosella bursepastaris

Sowthistle, annual

Sonchus oleraceus

Groundsel, common

Senecio vulgaris

- Use a minimum of 1.5 quarts of this product in these mixtures.

NOTE: This recommendation does not preclude the use

of Goal in these mixtures at higher, labeled rates for preemergence weed control.

\section{PERENHIAL GRUSS SUPPRESSION ORCHARO nOORS}

When applied as directed. this product will suppress vegetative growth as indicated below.

\section{Dhiagess}

This product will provide significant inhibition of seedhead emergence and will suppress veetative growth for a period of approximately $45 \mathrm{dys}$ with a singte applica tion and approximatefy 120 das with sequential applcations. Apply this product 1 to 2 weets after full green-up or after mowing to a uniform height of 3 to 4 inches Apptications must be made prior to seedhead emerge.sce. Apply 6 fluid ounces of this product in 10 to 25 gallons of water per acre.

Sequential applications of this product mey be made at approximately 45-day intervals to extend the period of seedhead and regetative grouth suppression. for continued seedhead suppression, sequential applications must be made prior to seedhead emerence. Appty no more than 2 sequential applications per year. As a first sequential appliction, apply 4 fluid ounces of this product per scre $A$ second sequential appliction of 2 to 4 fluid ounces per acre my be made appraimatety 45 drys after the last applieation.

Bermudatra:

For burndown, apply 1 to 2 quarts of this product in 3 to 20 gallons of water pes sere. Use 1 quart in 3 to 20 callons of wates pes acre east of the Rocty Mountuins. Use 1 to 2 quarts of this product in 3 to 10 atlons of water pet acre west of the Rochy Mountains. Use this treatment only if reduction of the bermudagrass stand can be tolerated. When burndown is required prior to harvest, allow at least 21 days to ensure sufficient time for burndown to occur.

Suppresion anty - (east of the Rocty Mountuinst Apphy 6 to 16 fluid ounces of this product in 31020 gallons of water per acte no soones than 1 to 2 weeks after full green-up. Mowine prior to application may oceur provided a minimum height of 3 inches is maintained. Rates of 6 to 10 fluid ounces should be used where a lesser dertee of suppression is desired. Sequential applications may be made when reprourth occurs and bermudagrass injury and stand reduction can be tolerated.

Suppresion onts - fwest of the Rochy Mountainst Apphy 16 fluid ounces of this product in 3 to 10 gallons of wate per acte to bermudagrass up to 6 inches in height and no soone than 1 to 2 weeks after full green-up. Mowing priof to applicetion may occur provided a minimum height of 3 inches is maintsined. Sequential applications my be made when regrowth occurs and bermudagras injury and stand reduction can be tolerated.

Cootseren Gress Corers

For suppression of tall feccue, fine fescue, orchard grass and quackgrass, apply 8 fluid ounces of this product in 10 to 20 gallons of water per acre. For best suppression. add ammonium sulfate to the spray solution at a rate of 2 percent by weight $\alpha 17$ pounds per 100 gallons of spray solution

For suppression of Kentucky bluegrass covers, apply 6 fluid ounces of this product per acse. Do not add ammo. nium sutfate.

For best results. mow cool-season grass coret in the spring to eren the height and apply the recommended rite of this product 3 to 4 dass atter mowing Aroid treat. ing coolseason grass corers under poor growing condi. tions, such as drought stress (drip inigation), disease or insect damage.

LNH-YOUME APPLCATION (Flarida and Ters)

For bumdown or control of the weeds listed, apply the recommended rate of this product in 3 to 30 gallons of wates per acre. Where weed foliage is dense, use 10 to 30 gallons of wrtes per acre.

\section{Annual Heeds}

Cartriced-Apph 2 to 3 quarts per acre of this product plus 17 pounds of ammonium sulfate per 100 gallons of wate. Appty in 20 to 30 eallars of wate per sore when phats are sctively growine. Use 2 quats per acre when phats are les than 8 inches bill and 3 quarts per scre when plants are greater than 8 inches If gatweed is sueter than 8 inches, the addition of Kover II or Ka. $m x^{\pi}$ my improve control. Use labeled rates for these residual products.

Read and carefully obsene the babel claims autionary teternents, rats and all other information on the Kores II and Kamex babls.

\section{Pernaial Weeds}

Apoly when weeds are activet growing and at the growth stetes listed in the "Perennial Weeds Controlled" section of this label. If perennial weeds are mowed, allow weeds to regrow to the recommended stage of growth. 
$S=$ Suppression, $B=$ Burndown, $C=$ Control, $P C=$ Partial control

\begin{tabular}{lccccc}
\hline WEED & \multicolumn{4}{c}{ RULLR } \\
SPECIES & 1 qt & 2 at & 3 at & 5 at \\
\hline Bermudagrass & B & $\bullet$ & PC & C \\
Guineagrass & & & & \\
Texas and Florida Ridge & B & C & C & C \\
Florida flatwoods & - & B & C & C \\
Paragrass & B & C & C & C \\
Torpedograss & S & - & PC & C \\
\hline
\end{tabular}

Calive is a trademart of Cibsceig Corparation.

- Cool is a trocenart of Rohm and Hars Company.

Wrmex and Krover en trodemarts of EL L du Pont de Nernours and Company.

Solkeam is a trademart of Sandor Ine.

-Surflan is a trademart of Elanco Products Company.

\section{TREE CROPS}

Citus citon, grapetruit, kumquat lemon, lime, orange. pummelo, tangelo. tangerine. tangors.

Nutsea: almond, chestnuts, filbert, macadamia, pecan, pistachio, walnut.

Peane fruit?: apple, pear.

Stone fruit ton: apricots, cherries, nectarines, olimes, peaches, plums/prunes.

For cherries, any application equipment listed in this section may be used in all states.

For citron and olives, apply as a directed spray only.

Ami application equipment listed in this section may be used in apricots nectarines, peaches, and plums/prunes rowing in Avizona. California, Colorado. Idaho. Kansas. Kentuchy, New Jersey. North Dakota, Othahoma, Orezon. Texas, Utah, and Washington, except for peaches grown in the states specified in the following paragraph. In all other states use wiper equipment onhy.

For PEACHES grown in Nabama, Artansas, Florida, Georgia, Louisiana, Mississippi, Narth Carolina, South Carolina, and Tennessee only. apply with a shielded boom sproyes or shielded wiper applieator which prevents any contact of this product with the foliage or bark of trees. Apply no later than 90 days after first bloom. Applica tions made after this time moy result in severe damage. Renowe suckers and low hanging limbs at least 10 das prior to application. Avoid applieations near trees with recent pruning wounds or other mechanical injury. Apphy caly near trees which hove been planted in the orchard to 200 more years. DTREME CARE MUST BE TAKEN TO EASURE NO PART OF THE PELCH TREE IS CONTACTED.

Tropied Fruit acerola, atemoy", arocado", banana (plantains), breadfruit", conistel". carambola",

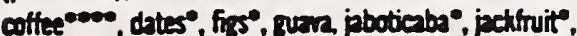
bongan", bchee", mango". papaya, passion truit". persimmons", sapodilla, sapote, soursop, sugar apple". tamarind, tea. Allow a minimum of 1 day between last application and hamest of guare and papay. In coffee and banana. delay applications 3 months after tons planting to allow the new coffee or banana plant to become established.
NOTE:

-Allow a minimum of 14 das between last applieation and havest

- Allow a minimum of 21 doss between last applieation and hamest.

- Nlow a minimum of 17 days between last application and havest

-*** Nilow a minimum of 28 days between last application and harrest.

VINE CROPS

Nivi Fruit

Caper Any rariety of table, wine, or risin grape may be treated with any equipment listed in this section.

In the northeast and Great Lakes regions, applications must be made prior to the end of bloom stage of erapes to avoid injury.

\section{NOTE:}

Applications should not be made when green shoots. canes, or foliage are in the spray zone.

Alow a minimum of 14 days between last application and harvest.

Product protected by

U.S. Pat Mo. 4,405.531.

Other patents pending.

No license granted under amy non-U.S. patent(s).

EPA Rez. Na 524-326-2935 GPL-1100.04/CC

In case of a human health emengency involving this product. Call Collect. day or night, (314) 6944000 .

Distributed by

Wilbur-Ellis Company

P.O. Bor 16458

freeno, Ca 93755 


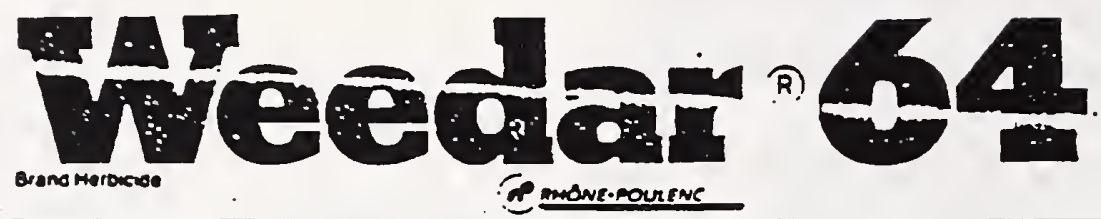

The 2,4-D Amine Weed Killer

ACTIVE INGREDIENT:

2,4-Dlchlorophenoxyacetlc acid, dimethylamine salt*

INERT INGREDIENTS:

$-2,4$-Dichlorophenoxyacetic acid equivalent $38.9 \%$ by weight or 3.8 pounds per gallon

-Isomer specific by AOAC method No. 6.D01.5

E.P.A. Reg. No. 264-2AA

E.P.A. Est. No. 264-MO.01

\section{KEEP OUT OF REACH OF CHILDREN

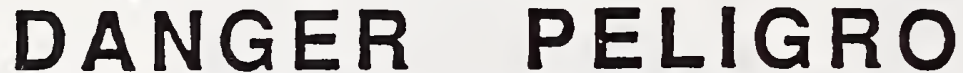

PRECAUTION AL USARIO: Si usted no lee inales, no use este producto hasta que la etieveta le haya sido explicado ampliamente.

For PBODUCI USE Information Call 1-800-334-9745

For EMERGENCY Information QNLY Call 24 Hours A Day 1-800-334-7577.

\section{STATEMENT OF PRACTICAL TREATMENT}

IF ON SKIN: Wash skin with plenty of soap and water. Remove contaminated clothing. Got medical attention.

IF SWALLOWED: If patient is conscious and alen, give 2 to 3 giasses of water or milk to drink. If available. give one tablespoon of Syrup of lpecac to induce vomiting. Alternatively, induce vomiting by touching back of throat with finger. Do not make an unconscious person vomit. Get medical attention.

IF IN EYES: Flush with water for at least 15 minutes. Got medical attention, PREFERABLY AN OPTHAMOLOGIST.

IF INHALED: Move to an uncontaminated area. Got medical attention. NOTE TO PHYSICIAN

This product contains a phenoxy herbicidal chomical. There is no specific antider. Aynreatments should be based on observed signs and symptoms of distress in the patient. Overexposure to materials other thaf fris protuct may have occurred.

\section{PRECAUTIONARY}

\section{DANGER}

\section{HAZARDS TO HUMANS AND}

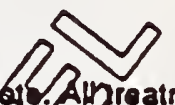

Harmful it swallowed. May bo fatal if absorbed through the skin sases irreversible eye damage. Avoid breathing vapors of spray mist. Do not get in eyes, on skin, or on clothing. When handling this product, wear goggles or salety glasses, protective clothing and chemical resistant gloves. Wash thoroughly with soap and aster handing and belore eating, drinking or using tobacos. Remove contaminated clothing and wash betore rouse.

\section{ENVIRONMENTAL HAZARDS}

This product is toxic to aquatic invertebrates. Drit on what may adversely affect aquatic invertebrates and non-target plants. Do not apply directly to water except as specified on this GbogDo not contaminate water when disposing of equipment washwaters. Do not apply when weather conditions favor drith fropt trefod areas. Do not use the same spray equipment for other purposes unless thoroughty cleanod.

Do not contaminate water used for irrigatignoy domestic purposes (except-as specilically recommended on this label) especially in areas where grapes, cotton, tomatoes or git (susceptible plants are grown. Do not treat irrigation ditches in areas water will be used to overhead (sprinkler) irrigate suscoptible crops especially grapes,
tomatoes, tobacco, and cotton.

MIXING AND LOADING: Most cases of ground water contamination involving phenoxy herbicides such as 2,4-D have been associated with mixinghoading and disposal sites. Caution should be exercised when handling 2,4-D pesticides at such sites to prevent contamination of ground water supplies. Use of closed systems for mixing or transferring this pesticide will roduce the probability of spills. Placement of the mixinghoading equipment on an impervious pad to contain spills will help prevent ground warer contamination.

Do not apply WEEDAR 64 Broadleaf Herbicide directly to, or permit to drift onto cotton, okra, grapes tomatoes, truin trees, vegetables, flowers or other desirable crep or ornamental plants which are susceptible to 2,4-D herbicide. Do not apply near susceptible plants since very small quantities of the 2.4-D will cause severe injury during the growing or dormant periods. Crops contacted by WEEDAR 64 Broadleat Herbicide sprays or spray dritt may be killed or sutter signiticant stand bss with extensive quality and yiold roduction.

Do not apply when a temperature air inversion exists. Such a condition is characterized by little or no air movement and an increase in air temperature with an inerease in height. In humid regions, a fog or mist may form. An inversion may be dotected by producing a smoke column and checking for a layering effect H questions exist pertaining to the existence of an inversion, consult with beal weather services bolore making an application. 


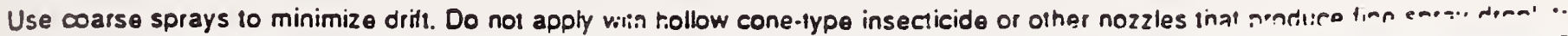

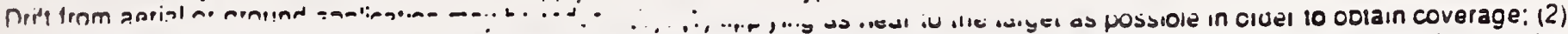
Dy increasung ine volume of spray mix per acre; (3) by decreasing the pounds of pressure at the nozzle lips; and (4) by using nozzles which produce a coarse spray pattern; (5) by not applying when wind is blowing roward susceptible crops or valuable plants.

\section{DIRECTIONS FOR USE}

It Is a violaiton of Federal law to use this product in manner Inconsistent with its labeling. Read entire label belore using ihls label.

\section{GENERAL WORKER PROTECTION STATEMENTS}

Do not apply this product in such a manner as to directly or through drif expose workers or other persons. The area treated must be vacated by unprotected persons. Do not enter treated areas without protective clothing until sprays have dried. Because cenain states may require more restrictive reentry intervals for various crops treated with this product, consult your State Depanment of Agriculture for funther intormation. Wrinen or oral warnings must be given to workers who are expected to be in a treated area or in an area about to be treated with this product. Advise workers to stay out of fields during application and until sprays have dried. Regular long-sleeved work clothing should be worn when working in trealed fields. Soe PRECAUTIONARY STATEMENTS. STATEMENT OF PRACTICAL TREATMENT and NOTE TO PHYSICIAN for information on accidental exposures. When oral warnings are given, warnings shall be given in a language customarily understood by workers. Oral warnings must be given if there is reason 10 believe that wrinen warnings cannot be understood by workers. Written warnings must include the following information: appropriate signal word (DANGER - PELIGRO), area treated with WEEDAR 64 Broadleat Herbicide, date of application, appropriate protective clothing. and reeniry interval (j.e. until sprays have dried).

\section{STORAGE AND DISPOSAL}

\section{STORAGE}

Do not contaminate water, food or feed by storage or disposal. Store in original container in a dry secured storage area. Keep container tightly closed when not in use.

PESTICIDE DISPOSAL

Pesticide wastes are acutely hazardous. Improper dispesal of excess pesticide, spray mixture, or rinsate is a violation of Federal law and may contaminate ground water. It these wastes cannot be disposed of by use according to label instructions, contact your State Pesticide or Environmental Control Agency, or the Hazardous Waste representative at the nearest EPA Regional OHtice for guidance.

CONTAINER DISPOSAL

Triple sinse or (equivalent). Then offer for recycling or reconditioning, or puncture and dispose of in a sanitary landfill, or incineration, or, if allowed by state and local authorities. by burnino. If burned. stay out of smoke.

\section{GENERAL CAUTIONS AND RESTRICTIONS}

Do not apply WEEDAR 64 Brcadleaf Herbicide through any type of irrigation system.

Do not use in or near a greenhouse.

\section{RESTRICTIONS AND LIMITATIONS FOR USE ON CEREAL GRAINS}

For aerlal applleatlon on grain. apply WEEDAR 64 Broadleaf Herbicide in 31010 gallons of water per acre.

For ground applleatlon a minimum of 10 to 15 gallons of water per acre is recommended for proper spray coverage.

De not permit dairy animals or meat animals being tinished for slaughter to forage treated grain fields winhin 2 weeks after treatment.

Do not feed treated straw to livestock if an emergency treatment as deseribed below is applied.

\section{RESTRICTIONS AND LIMITATIONS FOR USE ON CORN AND SORGHUM}

Do not forage or feed fodder for 7 days following application.

\section{RESTRICTIONS AND LIMITATIONS FOR USE IN FALLOWLAND AND CROP STUBBLE}

Do not plant any crop for 3 months ater treatment or until chemical has disappeared from the soil.

RESTRICTIONS AND LIMITATIONS FOR USE IN PASTURES AND RANGELANDS

Do not graze (dain) cattle in treated areas for 7 days atter application.

Do not cur forage for hay within 30 days of application.

Do not permit dairy animals or meat animals being finished for slaughter to forage treated fields winhin 3 days of slaughter.

RESTRICTIONS AND LIMITATIONS FOR USE ON CONSERVATION RESERVE PROGRAM AREAS:

Use at leasi 2 gallons of water per acre by ait and 5 gallons of water per acro by ground.

Do not harvest or graze treated Conservation Reserve Program areas.

Do not apply to grasses in the boot to dough stage if grass seed production is desired.

RESTRICTIONS AND LIMITATIONS FOR USE ON GRASSES FOR SEED PRODUCTION

Do not graze dairy animals or cut forage for hay within 7 days of application. 


\section{RESTRICTIONS AND LUMITATIONS FOR USE ON NON-CROPLAND}

Do not graze dairy animals for 7 days following application.

Use sutficiont gallonage for thorough and uniform coverage.

RESTRICTIONS AND LIMITATIONS FOR USE IN STONE FRUIT AND NUT ORCHARDS

Do not apply to bare ground as injury may result.

Do not apply immediatoly bolore irrigation and withhold irrigation for 2 days before and for 3 days ater treatment.

Do not allow spray to dritt onto or contact foliage, frunt, stoms, trunks of trees or exposed roots as injury may result.

Do not apply to nowly establishod or young orchards. Trees must be at least 1 year old and in vigorous condition.

Do not apply during bloom.

Do not graze or foed cover crops from treated orchards.

Do not make more than 2 applications por year.

Do not harvest stone frut within 40 days of application.

Do not harvest nuts within 60 days of application.

\section{MIXING INSTRUCTIONS}

Mix WEEDAR 64 Broadleat Herbicide only with water, Unless otherwise directed on this labol. Add about one-half the water to the mixing tank, then add WEEDAR 64 with agization and finally the rest of water with continuing agitation.

NOTE: Adding oil, wetting agent. or other surfactants to the spray may increase eflectiveness on woeds but also may reduce selectivity to crops, resulting in coop damage.

\section{COMPATIBILITY}

If WEEDAR 64 Broadleal Herbicide is to be tank mixed with fertilizers or with other pesticides, compatibility should be tested prior to mixing. To test for compatibility, use a small container and mix a small amount ( 0.5 to $1 \mathrm{qt})$ of spray, combining all ingredients in the same ratio as the anticipated use. If any indications of physical incompatibility develop, do not use this mixture for spraying. Indications of incompatibility usually will appear within 5 to 15 minutes ator mixing.

Read and follow all directions and precautions on this label and on the labels of any products for which a tank mixture is being considered.

\section{APPLICATION PROCEDURES}

Apply by air or ground oquipment in sufticient gallonage to obtain adequate coverage, except as otherwise directed on this label. Use 2 or more gallons of water por acre for aerial application and 10 or more gallons of water por acre for ground application.

\section{GENERAL INFORMATION}

INJURY TO CROPS FROM THIS HERBICIDE MAY OCCUR. IF YOU ARE NOT PREPARED TO ACCEPT SOME DEGREE OF CROP INUURY DO NOT USE THIS PRODUCT.

Crop varieties vary in response to 2,4-D and some are easily injured. Apply WEEDAR 64 Broadleal Herbicide only to varieties known to be tolerant 10 2,4-D. If you are uncertain concerning tolorant varioties or local use situations that may affect crop tolerance to 2,4-D. consuth your soed company, state Agriculiural Extension Service or qualified crop consultant for advice.

Be sure that use of this product conforms to all applicable laws, rulos and regulations. Cortain states have restrictions pertaining to application distances from susceptible crops. The applicator should become familiar with these laws, rules or regulations and follow them oxactly.

\section{GENERAL WEED LIST}

Annual and Blennlal Weeds

\begin{tabular}{|c|c|c|}
\hline •beggarticks & -mallow (venice or little) & -Russian thistle \\
\hline bullthistle & marsheldor & Salsity (wostom or common) \\
\hline colfeeweod & morningglory (common, ivy, wooly) & - smartwoods (annual spocies) \\
\hline common cocklebur & musk thistle("••) & sowthistles (annual or spiny) \\
\hline common burdock & mustards (except blue mustard) & sunflower \\
\hline common evening primrose & pepper weods (except perennial) & 'vervains \\
\hline common lambsquarters & •pigwoods (Amaranthus spp.) & vetches \\
\hline hainy galinsoga & prickly lottuce & wild carrot \\
\hline jimsonweod & ragweed (common or giant) & wild lettuco \\
\hline knotweod & rough fleabane & wild parsnips \\
\hline
\end{tabular}


Perennial Weeds

\begin{tabular}{lll}
\hline "bindweed (hedge, field, European) & "goldenrod & "nettles (including stinging) \\
blue lettuce & 'ground ivy & "orange hawkweed \\
'Canada thistle & healall & plantains \\
cainip & "hoary cress & somhistle (perennial) \\
chicory & -ironweed & 'vervains \\
dandelion & Jerusalem-artichoke & "wild garlic \\
'docks & many flowered aster & 'wild onion
\end{tabular}

-dogbanes

-These species may require repeated applications and/or use of the higher rate recommended on this product label even under ideal conditions for application.

- Control of pigweeds in the High Plains area of Texas and Oklahoma may not be satisfactory winh this product.

- Not registered for control of musk thistlo in Calitornia.

\section{SPECIFIC USE DIRECTIONS}

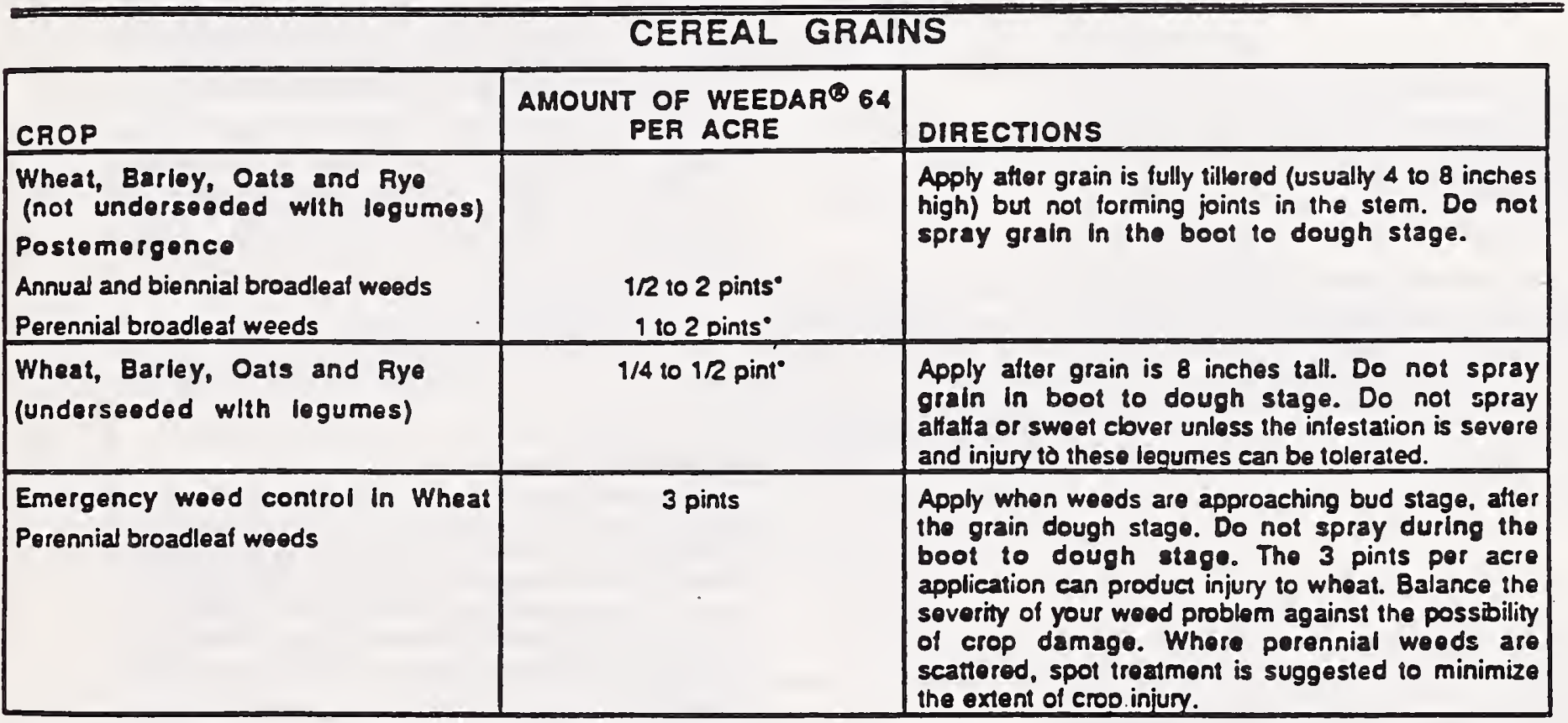

\footnotetext{
Use the lower rate if small annual and biennial weeds ase the major proolem. Use the higher rate if perennial woeds of annual and biennial weeds are present which are in the hard-to-kill categories as determined by local experience. The higher rates increase the risk of grain injury and should be used only where the weed control problem justifies the grain damage risk. Do not apply WEEDAR 64 to grain in the seedling stage.
} 


\begin{tabular}{|c|c|c|}
\hline $\begin{array}{l}\text { CORN (Flold and Swoot) } \\
\text { Proplant }\end{array}$ & 1 to 2 pints & $\begin{array}{l}\text { To control emerged broadleaf weed seedlings or } \\
\text { existing cover crops prior to planting com, apply } 7 \text { to } \\
14 \text { days before planting. Do not use on light, sandy } \\
\text { soil, or where soil moisture Is inadequate for normal } \\
\text { weed growth. Use high rate for less susceptible } \\
\text { weods or cover crops such alfalfa. }\end{array}$ \\
\hline Preomergence & 2103 pints & $\begin{array}{l}\text { Apply } 3 \text { to } 5 \text { days after planting but botore corn } \\
\text { emerges. Do not use on light, sandy soils or where } \\
\text { soil moisture is low. }\end{array}$ \\
\hline $\begin{array}{l}\text { Postemergence } \\
\text { Annual broadleal weods } \\
\text { Perennial broadleaf woeds }\end{array}$ & $\begin{array}{l}1 / 2 \text { to } 1 \text { pint } \\
1 \text { to } 11 / 2 \text { pints }\end{array}$ & $\begin{array}{l}\text { Apply when woeds are small and com is less than } 8 \\
\text { inches tall (to top of canopy). When corn is over } 8 \\
\text { inches tall, use drop nozzles and keop spray off } \\
\text { toliage. Treat porennial weeds when they are in the } \\
\text { bud to bloom stage. Do not spray corn in the } \\
\text { tassel to dough stage. Corn treated with } 2,4-0 \\
\text { may become temporarily brittle. Winds or cultivation } \\
\text { may cause stalk breakage during the poriod of time } \\
\text { when the corn is brittle. }\end{array}$ \\
\hline $\begin{array}{l}\text { Graln Sorghum (Mllo) } \\
\text { Postemergence }\end{array}$ & I pint & $\begin{array}{l}\text { Apply when sorghum is } 6 \text { to } 15 \text { inches tall. If sorghum } \\
\text { is taller than } 8 \text { inches to top of the canopy. use drop } \\
\text { nozzles and keep spray off the foliage. Do not } \\
\text { treat durlng the boot, flowering or dough } \\
\text { stage. }\end{array}$ \\
\hline
\end{tabular}

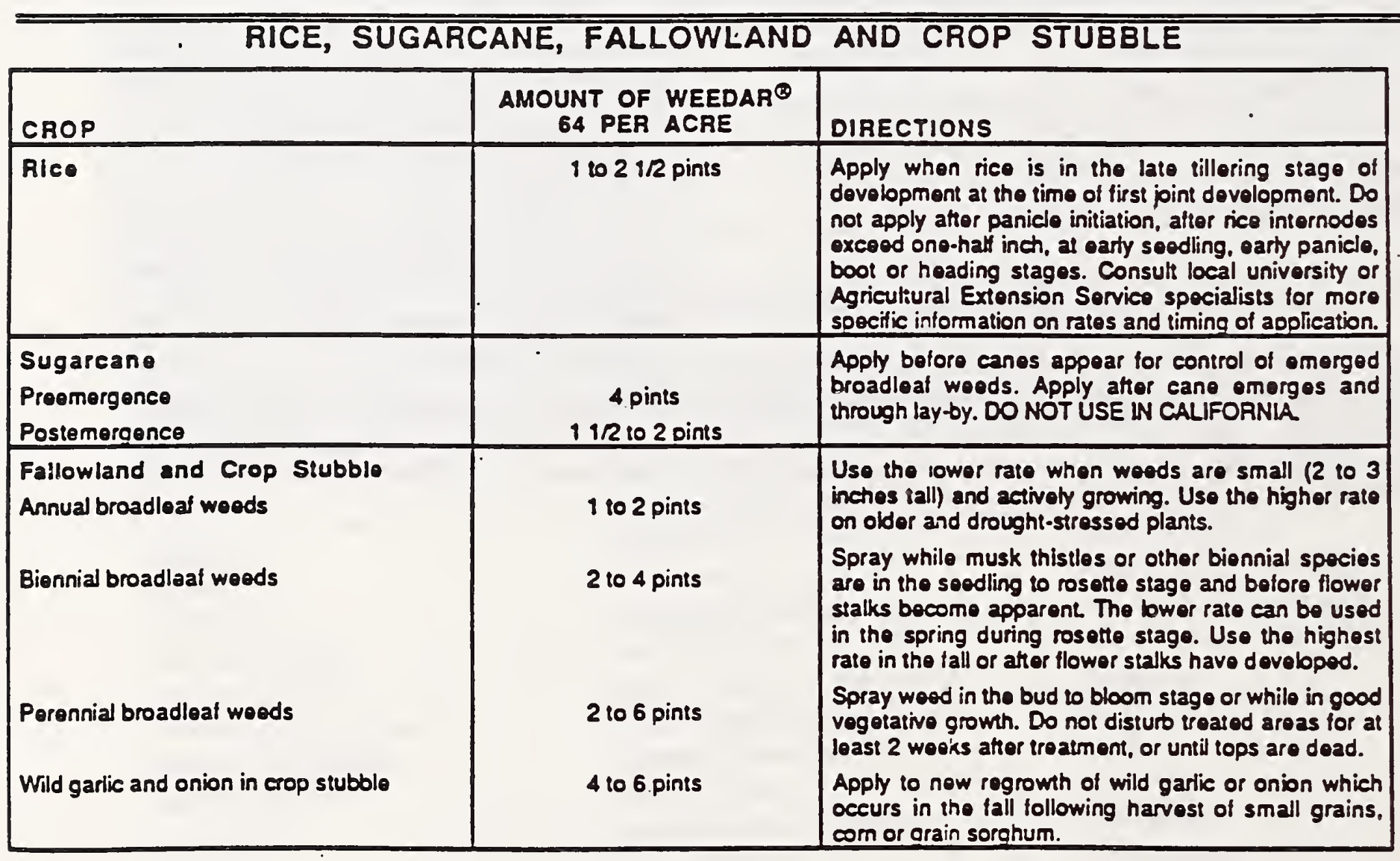




\section{ESTABLISHED GRASS PASTURES, RANGELAND, AND CONSERVATION RESERVE PROGRAM AREAS}

\begin{tabular}{|c|c|c|}
\hline WEEDS & $\begin{array}{c}\text { AMOUNT OF WEEDAR } \\
64 \text { PER ACRE }\end{array}$ & DIRECTIONS \\
\hline $\begin{array}{l}\text { Annual broadleal weeds } \\
\text { Blennlal and perennlal broadleat } \\
\text { weeds }\end{array}$ & 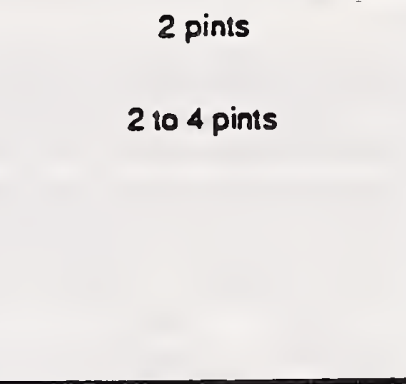 & $\begin{array}{l}\text { Apply when weeds are small and actively growing and } \\
\text { prior to bud stage. Spray while musk thistlos or other } \\
\text { biennial species are in the seedling to rosette stage } \\
\text { and before flower stalks become apparent. The lower } \\
\text { rate can be used in the spring during rosette stage. } \\
\text { Use the highest rate in the fall or alter flower stalks } \\
\text { have developed. Do not apply to newly seeded areas } \\
\text { until grass is well ostablished. Do not apply to grass in } \\
\text { the early boot through milk stage if grass seed } \\
\text { production is desired. Bentgrass and legumes may be } \\
\text { iniured by this treatment. }\end{array}$ \\
\hline
\end{tabular}

CONSERVATION RESERVE PROGRAM AREAS

\begin{tabular}{|c|c|c|}
\hline WEEDS & $\begin{array}{c}\text { AMOUNT OF WEEDAR }{ }^{\oplus} 64 \\
\text { PER ACRE }\end{array}$ & DIAECTIONS \\
\hline $\begin{array}{l}\text { Annual broadleat woeds } \\
\text { In young grasses } \\
\text { In established grasses }\end{array}$ & $\begin{array}{l}1 / 2 \text { to } 1 \text { pint } \\
1 / 2 \text { to } 2 \text { pints }\end{array}$ & $\begin{array}{l}\text { Apply to actively growing annual broadleal woeds. } \\
\text { Use } 1 / 2 \text { to } 1 \text { pint when woods are small; use higher } \\
\text { rates on older weods. Do not apply to young grasses } \\
\text { with fower than } 6 \text { leaves or prior to tilloring, as } \\
\text { excessive injury may result. Do not apply more than } 1 \\
\text { pint until grasses are woll established as excessive } \\
\text { injury may result. }\end{array}$ \\
\hline $\begin{array}{l}\text { Blennial and perennlal broadleaf } \\
\text { woeds } \\
\text { in established grasses }\end{array}$ & 2104 pints & $\begin{array}{l}\text { Treat when biennial woeds are in the seedling to } \\
\text { rosente stage and bolore flower stalks become } \\
\text { apparent. Treat perennial woeds in the bud to bloom } \\
\text { stago. Aoply to actively orowing weods. }\end{array}$ \\
\hline
\end{tabular}

\begin{tabular}{|c|c|c|}
\hline \multicolumn{3}{|c|}{ GRASSES FOR SEED PRODUCTION } \\
\hline WEEDS & $\begin{array}{l}\text { AMOUNT OF WEEDAR }{ }^{\oplus} 64 \\
\text { PER ACRE }\end{array}$ & DIRECTIONS \\
\hline $\begin{array}{l}\text { Annual and perennial broadleaf } \\
\text { weeds }\end{array}$ & 2104 pints & $\begin{array}{l}\text { Apply to established stands in spring from tiller to } \\
\text { early boot stage. Do not spray in boot stage. } \\
\text { Now spring seedings may be treated with the lower } \\
\text { rate atter grass soedlings have at loast } 5 \text { leaves. } \\
\text { Perennial weed regrowth may be treated in the lall. DO } \\
\text { NOT USE IN CALIFORNIA. }\end{array}$ \\
\hline
\end{tabular}

\begin{tabular}{|c|c|c|}
\hline \multicolumn{3}{|c|}{$\begin{array}{c}\text { NON-CROPLAND } \\
\text { fencerows, roadsides, drainage ditches, golf courses, cemeteries, } \\
\text { parks, turfgrass, and other grass areas }\end{array}$} \\
\hline WEEDS & $\begin{array}{c}\text { AMOUNT OF WEEDAR@ } 64 \\
\text { PER ACRE }\end{array}$ & DIRECTIONS \\
\hline $\begin{array}{l}\text { Annual broadleat weods } \\
\text { Blennial and perennial broadleal } \\
\text { weeds }\end{array}$ & $\begin{array}{l}2104 \text { pints } \\
4808 \text { pints }\end{array}$ & $\begin{array}{l}\text { Treat when woeds are young and activoly growing. } \\
\text { Porennial woeds should be near the bud stage, but } \\
\text { not flowering at application. Do not use on susceptible } \\
\text { southern grasses such as St. Augustine. Do not } \\
\text { apply to newly seeded areas until grass is woll } \\
\text { established. Bentgrass, elover, legumes and } \\
\text { dichondria may be iniured by this treatment. }\end{array}$ \\
\hline
\end{tabular}




\section{SPOT TREATMENT IN NON-CROP AREAS}

Mix 2 to 3 fluid ounces of WEEDAR 64 Broadleaf Herbicide in 3 gallons of water. Wot all weods and stems thoroughty. For best results, treat when woods are actively growing.

\section{FORESTRY - TREE INJECTION \\ For controlling specles such as alder, aspen, blrch, blackgum, cherry, oak, sweetgum, and tullp poplar}

Make injections as near to the root collar as possible, using one injection per inch of trunk dbh (4 1/2 leot). For resistant species such as hickory, injections should overlap. For best results, injections should be made during the growing season, May 15 th through October 15th.

For Dllute injection: Mix 1 gallon of WEEDAR 64 Broadieal Horbicide in 19 gallons of water for dilute injections.

For Concentrate Injections: Use 1 to $2 \mathrm{ml}$ of concentrate WEEDAR 64 Broadloal Herbicide per injection. The injection bit must penetrate the innor bark.

\begin{tabular}{|l|c|c|}
\hline \multicolumn{2}{|c|}{ STONE FRUIT AND NUT ORCHARDS } \\
\hline WEEDS IN CROP & $\begin{array}{c}\text { AMOUNT OF WEEDARQ 64 } \\
\text { PER ACRE }\end{array}$ & OIRECTIONS \\
\hline Annual broadleat woods & 3 pints & $\begin{array}{l}\text { For control of woods on the orchard floor, apply using } \\
\text { coarse sprays and bw prossure in sutticiont volume } \\
\text { of water to obtain thorough wetting of woeds. Troat } \\
\text { when woods are small and actively growing. Do not } \\
\text { uso on light, sandy soil. DO NOT USE IN } \\
\text { CALIFORNIA. }\end{array}$ \\
\hline
\end{tabular}

WEEDS AND BRUSH IRRIGATION CANAL DITCHBANKS
(Seventeen Western States: Arizona, California, Colorado, Idaho, Kansas,
Montana, Nebraska, New Mexico, Nevada, North Dakota, Oklahoma, Oregon,
South Dakota, Texas, Utah, Washington, and Wyoming).

For control of annual and perennial broadloal woods, apply 1 to 2 quarts of WEEDAR० 64 Broadleaf Horbicide por acro in approximatoly 2010100 gallons per acre. Treat when weeds are young and activoly growing bolore the bud or earty bloom stage. For harder-to-control weods, a repoat spray attor 3 to 4 wooks using the same rates may bo noeded for maximum results. Apply no more than two troatments per season.

For woody brush and patchos of perennial broadleat woeds, mix I gallon of WEEDAR` 64 in 150 gallons of water. Wot foliage thoroughly using about 1 gallon of solution per square rod.

SPRAYING INSTRUCTIONS

Apply with low pressure (10 to 40 psi) power spray equipment mounted on a truck, tractor, or boat. Apply while travoling upstream to avoid accidental concontration of chemical into water. Spray when the air is lairly claim, $5 \mathrm{mph}$ or less. Do not use on small canals (less than 10 cts) where water will bo used for drinking purposes.

Boom spraying onto water surface must be hold to a minimum and no cross-stream spraying to opposite banks should bo permited. When spraying shoreline weeds, allow no more than 2 foot overspray onto water with an average of less than 1 loot overspray to prevent introduction of greater than negligible amounts of chemical into the wator.

Do not allow dain animals to graze on troated aroas for at least 7 days attor spraying. Wator within troated banks should not be fishod.

\section{AQUATIC WEED CONTROL}

For usa in ponds, lakes, reservolrs, marshes, bayous, drainage ditches, canals, ilvers and streams that are quiescent or slow moving.

NOTICE TO APPLICATORS

State and Local Coordination: Botore application, coordination and approval of local and state authorities may be required. either by lotter of agreement or issuance of spocial permits for such use.

Fish Toxlctty - Oxygen Ratlo: Fish breathe oxygen in the water and a water - oxygen ratio must be maintained. Decaying weeds use up exygen. To avoid fish kill from decaying plant material do not treat more than one hall the lake or pond at one time. For large bodies of weed infested waters leave buffer strips of al least 100 loet wide and delay treatment of these strips tor 4 to 5 weeks or unti the dead vegeration has decomposed.

Wind Veloclty - Ground or Surface Applicatlon: Do not apply when wind speods are at or above $10 \mathrm{mph}$. Alr Applicatlon: Do not apply when wind speeds are at or above $5 \mathrm{mph}$. The restrictions do not apply to subsurface applications used in weed control programs.

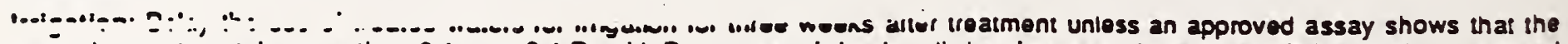
water does not contain more than $0.1 \mathrm{ppm} 2,4-\mathrm{D}$ acid. Do not treat irrigation ditches in areas whore water will be used to overhead sprinkler irrigate susceptible crops especially grapes, tomatoes and cotton. 
Potable Water: Delay the use of treateo water for comestic purposes for a period of three weeks or until surh fime as an .........nd

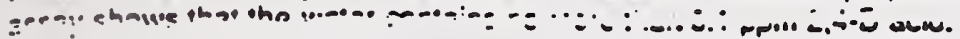

\section{Water Hyacinth (Ejchornia crassipe) - Directions For Use}

WEEDAR 64 will control water hyacinth wih surface and air applications.

Amounts to Use: 2 to 4 quarts (4 b. acid equivalent per gallon) per acre. Spray the weed mass only. Use 4 quarts when plants are matured or when the weod mass is dense.

When To Apply: Spray when water hyacinth plants are actively growing. Repeat as necessary to kill regrowth and hyacinth plants missed in the previous operation.

How To Use - Surface Application: Use power sprayers operated with a boom or spray gun mounted on a boat, Iractor or truck. Thorough wetting of foliage is essential for maximum control. Use 100 to $400 \mathrm{gal} / \mathrm{A}$ of spray mixture. Special precautions such as the use of low pressure, large nozzles and thickening agents should be taken to avoid spray drith in areas of sensitive crops. For DIAECTA. SPRA'M operation use WEEDAR 64 with 1 pint of dritt control agent in 5010100 gallons of water. For other applications, follow the dritt control agent label for mixing directions. Alt Applicatlon: Use drit control spray equipment or thickening agents mixed into the spray solution. Apply 1.0 gallon per ace of WEEDARs 64 through standard boom systems with a minimum of 5 gallons of spray mix per acre. For MICROFOIL dritt control spray systems, apply WEEDAR 64 in 12 to 15 gallons spray mix por acre.

\begin{tabular}{|c|c|c|c|}
\hline $\begin{array}{l}\text { 2.4-D Acid Equivalont } \\
\text { WEEDAR } 64\end{array}$ & $\begin{array}{l}\text { 1/2 b. } \\
1 \mathrm{pl} .\end{array}$ & $\begin{array}{l}1 \mathrm{lb} . \\
2 \text { pls. }\end{array}$ & $\begin{array}{l}2 \text { bbs. } \\
2 \text { gts. }\end{array}$ \\
\hline
\end{tabular}

\section{Water Milfoil (Myriophyllum spicatum) - Directions For Use}

For Eurasian Water Mithoil in programs condueted by the Tennessee Valloy Authority in dams and resenoirs of the TVA system. WEEDAR 64 will control water milfoil with surface, subsurface and air applications.

How To Uso: To control water milloil when less than 5 gallons of concentrate per acre is recommended, dilute the concentrate with water to apply a minimum of 5 gallons of spray mix per acre. Do not treat within $1 / 2$ mile of potable water intakes. Shoreline areas should be treated by sub-surface injection applied by boat to avoid aorial dritt. Do not apply whon weather conditions favor drift from target area. Do not contaminate water by cleaning of equipment washwaters.

Open Water Areas: To reduce contamination ard prevent undo exposure to fish and other aquatic organism. do not treat water areas that are not infested with aquatic weeds.

Amounts To Use: Apply 2.51010 gallons of WEEDAR 64 per acre. The higher rate is used in areas of greater water exchange. These areas may require a repeat application.

When To Apply: For best results, apply in spring or early summer when milloil stans to grow. This timing ean be checked by sampling the lake bortom in areas heavily infested whit weecs the year botore. .

Subsurface Applicatlon: Apply 2.5 to 10 gallons of WEEDAR 64 per acre as a concentrate directly into the water through boat mounted distribution systems.

Surface Application: Apply 2.5 to 90 gallors of WEEDAR 64 per acre in a minimum spray volume of 5 gallons mix per acre.

Alr Appllcatlon: Use dritt control spray equipment of thickening agents mixed into the spray solution. Apply 2.5 to 10 gallons per cre of WEEDAR 64 inrough standard.boom systems with a minimum of 5 gallons of spray mix per acre. For MiCROFOIL ${ }^{6}$ dritt control spray systems apply WEEDAR 64 in 12 to :5 gallons spray mix per acre. 


\section{LIMITED WARRANTY AND DISCLAIMER}

The manufacturer warrants that this product conforms to the chemical description on the label; that this product is reasonably fit for the purposes set forth in the directions for use when it is used in acoordance with such directions; and that the directions, warnings and other statements on this labol are based upon responsible exports' evaluation of reasonable tests of effectiveness. of toxicity to laboratory animals and to plants, and of residues on food crops, and upon reports of field experience. Tosts have not been made on all variotios or in all states or under all conditions. THE MANUFACTURER NEITHER MAKES NCR INTENOS, NOR DOES IT AUTHORIZE ANY AGENT OA REPRESENTATIVE TO MAKE, ANY OTHER WARRANTIES, EXPRESS OR IMPLED. AND IT EXPRESSLY EXCLUDES AND DISCLANMS ALL IMPLED WARRANTIES OF MERCHANTABILTY OR FITNESS FOR A PARTICULAR PURPOSE

THIS WARRANTY DOES NOT EXTEND TO, AND THE BUYER SHALL BE SOLELY RESPONSIBLE FOR, ANY AND ALL LOSS OR DAMAGE WHICH RESULTS FROM THE USE OF THIS PRODUCT IN ANY MANNER WHICH IS INCONSISTENT WITH THE LABEL DIRECTIONS, WARNINGS OR CAUTIONS.

BUYER'S EXCLUSIVE REMEDY AND MANUFACTURER'S OR SELLER'S EXCLUSIVE LIABILITY FOR ANY AND ALL CLAIMS. LOSSES. DAMAGES, OR INUUAIES RESULTING FROM THE USE OR HANDUING OF THIS PRODUCT, WHETHER OR NOT BASED WN CONTRACT. NEGLIGENCE. STRICT LLABILITY IN TORT OR OTHERWISE SHALL BE LIMITED, AT THE MANUFACTURERS OPTION, TO REPLACEMENT OF, OR THE REPAYMENT OF THE PURCHASE PRICE FOR, THE OUANTITY OF PRODUCT WTTH RESPECT TO WHICH DAMAGES ARE CLAIMED. IN NO EVENT SHALL MANUFACTURER OR SELLER BE LLABLE FOR SPECLAL, INDIRECT OR CONSEQUENTIAL DAMAGES RESULTING FROM THE USE OR HANDUNG OF THIS PRODUCT.

NOTHCE TO BUYER

Purchase of this material does not confer any rights under patents governing this product or the use thereof in countries outside of the United Satos. THIS SPECIMEN LABEL IS INTENDED FOR USE ONLY AS A GUIDE IN PROVIDING GENERAL INFOAMATION
REGARDING THE DIRECTIONS, WARNINGS AND CAUTIONS ASSOCIATED WITH THE USE OF THIS
PRODUCT. AS WITH ANY AGRICULTURAL CHEMICAL, ALWAYS FOLLOW THE LABEL INSTRUCTIONS ON THE
PACKAGE BEFORE USING.

Rhóno-Poulenc Ag Company

P.O. Box 12014, 2 T.W. Alexander Drive

Research Triangle Park, North Carolina 27709

Form No. 93482

Printed USA - 9/91

WEEDAR and MICROFOIL are registered trademarks of RHONE.POULENC.

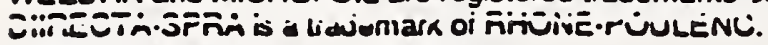

O1991 Rhóno-Poulone Ag Company

Made in USA.

EPA Approval: 6/24/91 


\section{Environmental Assessment}

\section{Noxious Weed \\ Management Plan}

Montana Fish, Wildlife \& Parks Region Seven

August 1996 



\section{TABLE OF CONTENTS}

Page

LIST OF TABLES iii

LIST OF FIGURES $\mathbf{v}$

1.0 THE PURPOSE OF AND NEED FOR ACTION $\ldots \ldots \ldots \ldots \ldots \ldots \ldots \ldots \ldots 1$

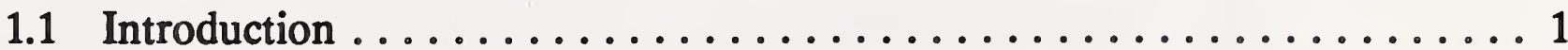

1.2 Noxious Weeds on Region 7 Properties ................. 2

1.2.1 The Setting and Current Conditions .............. 2

1.2.2 Noxious Weed Treatment History ............... 5

1.3 Noxious Weed Management Goals ...................... 12

1.4 Programs and Legal Framework Affecting Region 7's Weed Plan . . . . 12

1.4.1 Wildlife Management Area Management Plans .......... 12

1.4.2 County Weed District 5-Year Plans ................ 13

1.4 .3 House Bill \#395 . . . . . . . . . . . . . . . . . . 13

1.4.4 Other Noxious Weed Management Plans ..... . . . . . . . 13

1.4.5 Noxious Weed Trust Fund Environmental Impact Statement . . 14

1.4.6 Other Applicable Laws and Regulations ............. 14

1.5 Decisions to be Made ........................... 14

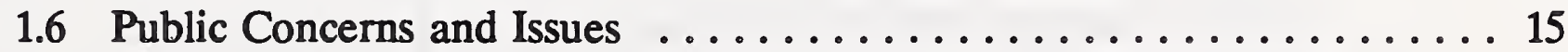

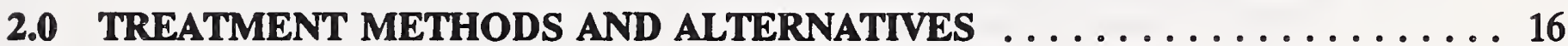

2.1 Treatment Methods ............................ 16

2.1.1 Chemical Methods ..................... 16

2.1.2 Non-chemical Methods ...................... 18

2.2 Description and Comparison of the Alternatives ............ 18

2.2.1 Alternative 1: Status Quo ....................... 19

2.2.2 Alternative 2: Integrated Noxious Weed Management ...... 19

2.2.3 Alternative 3: Chemical Methods ................ 20

2.2.4 Alternative 4: Non-Chemical Methods .............. 20

2.3 The Preferred Alternative ..................... 21

2.4 Cumulative Effects and Irreversible or Irretrievable Commitments . . . . 21

3.0 THE AFFECTED ENVIRONMENT AND ANALYSIS OF POTENTIAL

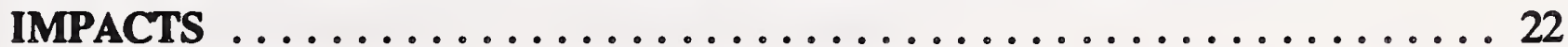

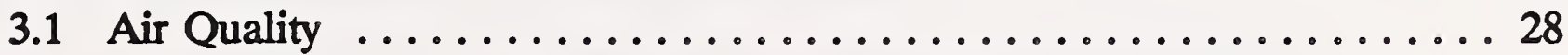

3.1 .1 Current Conditions ...................... 28

3.1.2 Analysis of Potential Impacts . . . . . . . . . . . . 28

3.2 Soils and Geology ............................. 29

3.2 .1 Current Conditions ........................ 29

3.2.2 Analysis of Potential Impacts . . . . . . . . . . . . 29 


\section{TABLE OF CONTENTS, continued}

Page

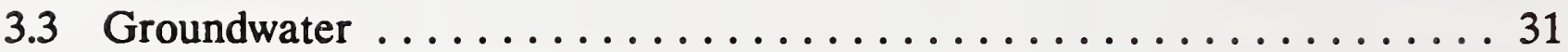

3.3.1 Current Conditions ...................... 31

3.3.2 Analysis of Potential Impacts . . . . . . . . . . . 31

3.4 Surface Water . . . . . . . . . . . . . . . . . . . . 34

3.4 .1 Current Conditions ........................ 34

3.4 .2 Analysis of Potential Impacts . . . . . . . . . . . . 35

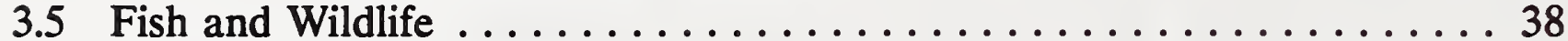

3.5.1 Current Conditions ......................... 38

3.5.2 Analysis of Potential Impacts . . . . . . . . . . . . . 39

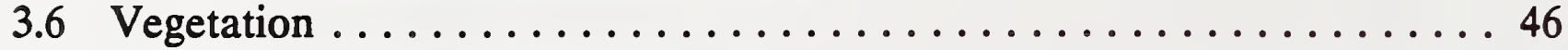

3.6.1 Current Conditions ....................46

3.6.2 Analysis of Potential Impacts . . . . . . . . . . . . . . 48

3.7 Recreation ........................... 50

3.7.1 Current Conditions ................... 50

3.7.2 Analysis of Potential Impacts . . . . . . . . . . . . . 51

3.8 Human Health . . . . . . . . . . . . . . . . . . . . 52

3.8.1 Current Conditions .................... 52

3.8.2 Analysis of Potential Impacts . . . . . . . . . . . 53

3.9 Cultural and Historic Resources . . . . . . . . . . . . . . . 56

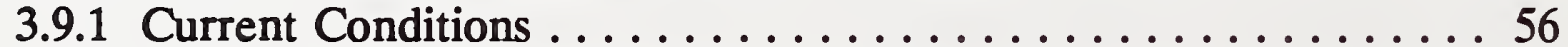

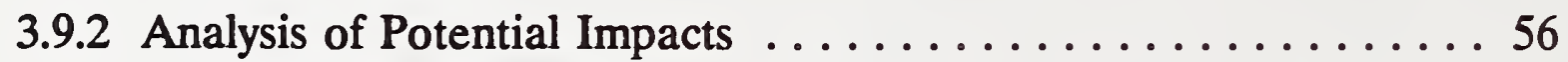

$3^{*} \quad$ Environmental Review Criteria ................... 58

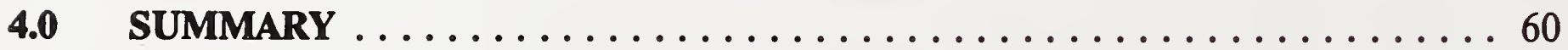

5.0 LIST OF CONTRIBUTORS AND REVIEWERS $\ldots \ldots \ldots \ldots \ldots \ldots \ldots$

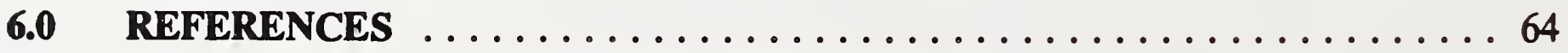

7.0 APPENDICES

APPENDIX A Herbicide Efficacy on State-Declared Noxious Weed Species Properties of Commonly Used Herbicides

APPENDIX B Fish and Wildlife Species Recorded in Latilongs Corresponding with Department of Fish, Wildlife and Parks Region 7 


\section{LIST OF TABLES}

Page

Table 1. Total expenditures by Montana Department of Fish, Wildlife and Parks Region 7 for weed management on its Wildlife Management Areas and on its Fishing Access Sites and State Parks combined during fiscal years (July 1 - June 30) 1989 and 1994

Table 2. Noxious weed species present and status on Department of Fish, Wildlife and Parks Wildlife Management Areas in Region 7

Table 3. Noxious weed species present and status on Department of Fish, Wildlife and Parks Fishing Access Sites in Region 7, by

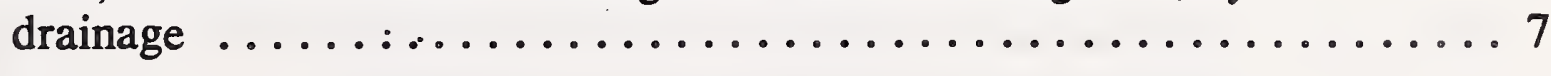

Table 4. Noxious weed species present and status on Department of Fish, Wildlife and Parks State Parks in Region 7 .......... 10

Table 5. Herbicides proposed for use on Department of Fish, Wildlife and Parks Region 7 properties, registered trade name and application rates on a per acre basis according to manufacturer label recommendations. . . . . . . . . . . . . . . . 16

Table 6. Summary of environmental impacts resulting from the implementation of the Noxious Weed Management Plan emphasizing Integrated Noxious Weed Management $\ldots \ldots \ldots 22$

Table 7. Maximum concentrations not to be exceeded in drinking water for herbicides proposed for use by Department of Fish, Wildlife and Parks in Region 7. Information provided by the United States Environmental Protection Agency, Office of Drinking Water, $1990 \ldots \ldots \ldots \ldots \ldots$. . . . . . . . . . . . . . . . 37

Table 8. A partial list of fish and wildlife species in southeast

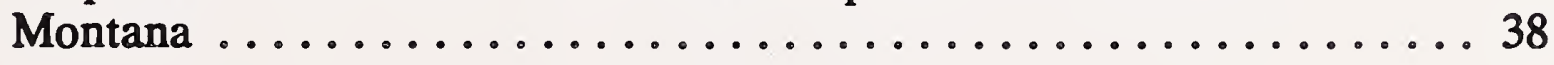

Table 9. Median lethal dose $\left(\mathrm{LD}_{50}\right)$ for domestic animals expressed in milligrams per kilogram for 7 herbicides proposed for use on Department of Fish, Wildlife and Park properties in Region 7 


\section{LST OF TABLES, continued}

Table 10. Routine and extreme dose levels of 2,4-D and glyphosate compared to the median lethal dose $\left(\mathrm{LD}_{50}\right)$ for various animal species. Table is adapted from the United States Department of the Interior, Bureau of Land Management Northwest Area Noxious Weed Control Program Final Environmental Impact Statement, 1985 . . . . . . . . . . . . . . . . . . . . . . . . 43

Table 11. Plant species of concern on Department of Fish, Wildlife and Parks properties in Region 7, as identified by the Montana Natural Heritage Program, 1995

Table 12. Summary and comparison of environmental impacts resulting from the implementation of each Alternative 


\section{LIST OF FIGURES}

Page

Figure 1. Properties owned by or leased to the Department of Fish, Wildlife and Parks in Region 7 3 



\subsection{THE PURPOSE OF AND NEED FOR ACTION}

\subsection{Introduction}

As mandated by the County Noxious Weed Control Act of 1979 (MCA 7-22-2115), "it is unlawful for any person to permit any noxious weed to propagate or go to seed on his land..." The Montana Department of Fish, Wildlife and Parks (DFWP) owns or leases approximately 18,000 acres in southeast Montana. Administratively, this land area is known as Region 7. DFWP proposes to manage noxious weeds on its properties in Region 7 by implementing a Noxious Weed Management Plan (Plan) (1996). The Plan outlines an integrated approach to weed management and would be used to guide site-specific, weed treatments beginning in the spring of 1996. The Plan would also be used to guide weed treatments under cooperative weed management projects in which Region 7 may participate.

Overall direction for noxious weed management is provided by DFWP's recently adopted Mission statement (DFWP 1992):

"to provide for the stewardship of the fish, wildlife, parks and recreational resources of Montana, while contributing to the quality of life for the present and future generations."

The primary goal of the program continues to be that stated in a general DFWP weed control policy adopted in 1983:

"to prevent to the extent feasible, the reproduction and distribution of agriculturally undesirable plant species throughout department lands or from department lands onto adjacent lands."

In accordance with the Montana Environmental Policy Act (MEPA), DFWP must examine and identify potential impacts of its actions on the natural and human environments. This Draft Environmental Assessment (EA) describes the direct, indirect, and cumulative effects of the proposed implementation of the Plan which is based on the concept of Integrated Noxious Weed Management. In addition, the EA presents alternatives to implementation of the Plan and describes the potential direct, indirect, and cumulative effects of implementation of these alternatives. 


\subsection{Noxious Weeds on Region 7 Properties}

\subsubsection{The Setting and Current Conditions}

Exotic (non-native) weedy plants have been noted in Montana throughout this century. In the past few decades, some species have become significant components of local vegetation communities, actually dominating some sites. DFWP draws a distinction between "weedy" species and "noxious" species. DFWP recognizes the value of some weed species (e.g. common dandelion) to wildlife as food and/or cover. As declared in law, "noxious" weeds are those species which are very aggressive and successful competitors for nutrients, moisture, and space and thereby encroach into a vegetation community. Important factors related to weed encroachment include proximity to water, site disturbance caused by humans or some other agent, and seed dispersal. The Draft Programmatic Environmental Impact Statement for the State of Montana's Noxious Weed Trust Fund provides a discussion of the origins of noxious weeds as well as the environmental and economic effects once they become established (Montana Department of Agriculture [MDA] 1991).

DFWP Region 7 boundaries overlap portions of Big Horn, Carter, Custer, Dawson, Fallon, Garfield, Prairie, Richland, Rosebud and Treasure Counties. Region 7 includes 10 Wildlife Management Areas, 23 Fishing Access Sites, and 6 State Parks. On three Fishing Access Sites, the DFWP leases acreage from other landowners who are responsible for maintenance and weed control activities. Figure 1 illustrates the locations of DFWP properties within the Region.

Wildlife Management Areas (WMA's) are managed to meet the needs of wildlife, preserve habitat, and provide recreational opportunities. Fishing Access Sites (FAS's) provide public access to high quality angling opportunities. State Parks (SP's) preserve unique, natural, cultural, historical, and recreational resources. Noxious weeds are present on all but a few sites, the number of noxious weed species and the size and degree of infestation varies considerably from site to site. Some patches consist of a few plants, while others are larger and more dense. Tables 2, 3, and 4 summarize the status of noxious weeds on Region 7 properties.

Of the 15 State-declared noxious weed species, approximately seven occur on Region 7 properties. These are Canada thistle, Leafy spurge, Spotted knapweed, Russian knapweed, Field bindweed, Dalmatian toadflax, and Purple loosestrife. Additionally, 11 species are declared noxious by the counties which overlap DFWP Region 7 boundaries. These are identified in the Plan. Some of these species occur on DFWP properties, with Common burdock, Salt cedar and Black henbane being the most frequent. 


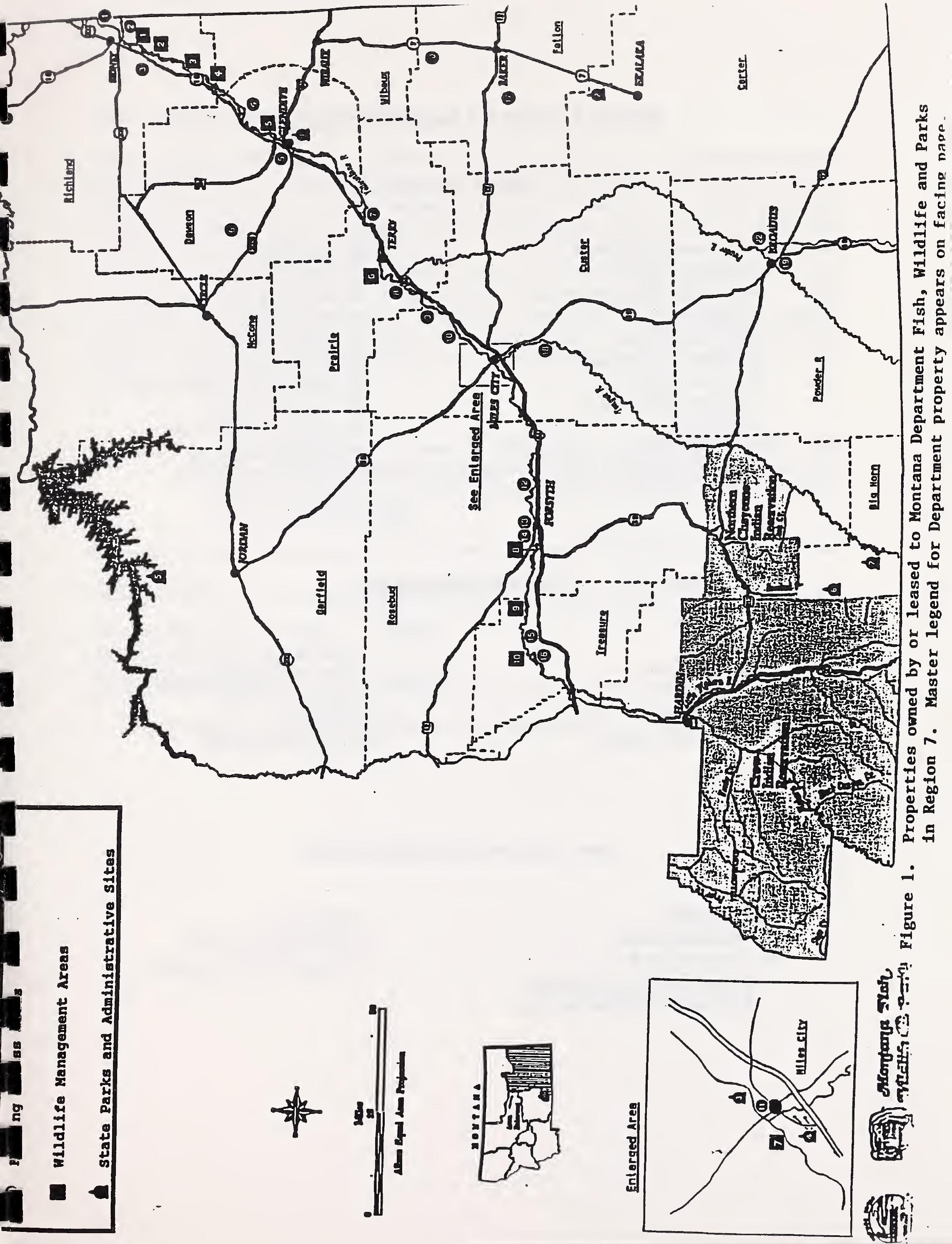




\section{Master Legend for Department Property}

Fishing Access Sites
1. Diamond Willow
2. Sidney Bridge
3. Gartside Dam
4. Intake
5. Hollecker Pond
6. Johnson Reservoir
7. Fallon Bridge
8. Powder River Depot
9. Bonfield
10. Kinsey Bridge
11. Roche Juane

12. Far West

13. East Rosebud

14. West Rosebud

15. Amelia Island

16. Myers Bridge

17. South Sandstone

18. Twelve Mile Dam

19. Broadus Bridge

20. Rush Hall Reservoir

21. Culbertson Bridge

22. Little Powder River

\section{Wildlife Management Areas}
1. F Island
2. Seven Sisters
3. Elk Island
4. War Dance
5. Three Mile Island
6. Badlands
7. Fort Keogh Islands (2)
8. Howard Valley
9. Sanders
10. Issac Homestead

\section{State Parks and Administrative Sites}

1. Makoshika

2. Medicine Rocks

3. Pirogue Island

4. Miles City Fish Hatchery \& Region Seven Headquarters
5. Hell Creek

6. Rosebud Battlefield

7. Tongue River Reservoir 


\subsubsection{Noxious Weed Treatment History}

Past weed management efforts on Region 7 properties have varied in method and intensity based on the noxious weed species present and their abundance. Typically, herbicide applications, mowing, and manual techniques (pulling or clipping) have been the primary treatment methods. Biological control experiments have also been initiated, with the first releases on Gartside Fishing Access in 1986. In 1989, biocontrol agents were released on several FAS's. In 1992, biocontrol agents were released at Intake Fishing Access. New releases have been conducted at Makoshika State Park within the last few years. DFWP has practiced an informal version of Integrated Noxious Weed Management since the passage of the County Noxious Weed Control Act in 1979. Table 4 illustrates DFWP Region 7 weed management expenditures for materials, personnel, and contracted services during fiscal years 1989 and 1994.

Table 1. Total expenditures by Montana Department of Fish, Wildlife and Parks Region 7 for weed management on its Wildlife Management Areas and on its Fishing Access Sites and State Parks combined during fiscal years (July 1 . June 30) 1989 and 1994.

Wildlife Management Areas

Fishing Access Sites and

State Parks combined

1 Total includes personnel, contracted services, and materials. 
Table 2. Noxious weed species present and status on Department of Fish, Wildlife and Parks (DFWP) Wildlife Management Areas in Region 7.

\begin{tabular}{|c|c|c|c|c|}
\hline $\begin{array}{l}\text { MAP KEY } \\
\text { NUMBER }\end{array}$ & $\begin{array}{l}\text { DFWP PROPERTY } \\
\text { NAME and ACREAGE }\end{array}$ & $\begin{array}{l}\text { WEED SPECIES } \\
\text { PRESENT }\end{array}$ & $\begin{array}{l}\text { WEED } \\
\text { SIZE }^{1}\end{array}$ & $\begin{array}{l}\text { STATUS } \\
\text { DENSITY }^{2}\end{array}$ \\
\hline 6 & Badlands (2.3) & none & & \\
\hline \multirow[t]{4}{*}{3} & \multirow{4}{*}{$\begin{array}{l}\text { Elk Island } \\
(1,208.5)\end{array}$} & Canada thistle & 3 & LDB \\
\hline & & $\begin{array}{c}\text { Russian } \\
\text { knapweed }\end{array}$ & 18 & $\mathrm{MD}$ \\
\hline & & Leafy spurge & $1 / 8$ & LDA \\
\hline & & Field bindweed & 3 & LDA \\
\hline 1 & F Island (94.7) & none & & \\
\hline 7 & $\begin{array}{l}\text { Fort Keogh Islands } \\
\text { (79) }\end{array}$ & none & & \\
\hline 8 & Howard Valley (.18) & none & & \\
\hline \multirow[t]{4}{*}{10} & \multirow[t]{4}{*}{$\begin{array}{c}\text { Issac Homestead } \\
(1,168.5)\end{array}$} & $\begin{array}{c}\text { Russian } \\
\text { knapweed }\end{array}$ & 2 & LDB \\
\hline & & Canada thistle & 5 & $\mathrm{MD}$ \\
\hline & & Poison hemlock & $1 / 64$ & LDA \\
\hline & & $\begin{array}{l}\text { other weed } \\
\text { species }\end{array}$ & 14 & LDB \\
\hline 9 & Sanders (.26) & none & & \\
\hline \multirow[t]{3}{*}{2} & \multirow[t]{3}{*}{ Seven Sisters (635.3) } & Leafy spurge & $1 / 16$ & $\mathrm{LDA}$ \\
\hline & & Canada thistle & 2 & LDB \\
\hline & & Field bindweed & 2 & LDA \\
\hline 5 & $\begin{array}{l}\text { Three Mile Island } \\
\text { (8.1) }\end{array}$ & none & & \\
\hline 4 & War Dance (11.5) & none & & \\
\hline
\end{tabular}

Size - page 11

2 Density - page 11 
Table 3. Noxious weed species present and status on Department of Fish, Wildlife and Parks (DFWP) Fishing Access Sites in Region 7, by drainage.

\begin{tabular}{|c|c|c|c|c|}
\hline $\begin{array}{l}\text { MAP KEY } \\
\text { NUMBER } \\
\end{array}$ & $\begin{array}{l}\text { DFWP PROPERTY } \\
\text { NAME and ACREAGE }\end{array}$ & $\begin{array}{l}\text { WEED SPECIES } \\
\text { PRESENT }\end{array}$ & \multicolumn{2}{|c|}{$\begin{array}{l}\text { WEED STATUS } \\
\text { SIZE }^{1} \text { DENSITY }^{2} \\
\end{array}$} \\
\hline \multicolumn{5}{|c|}{ YELLOWSTONE RIVER DRAINAGE } \\
\hline \multirow[t]{3}{*}{16} & \multirow[t]{3}{*}{ Meyer's Bridge (15) } & $\begin{array}{c}\text { Russian } \\
\text { knapweed }\end{array}$ & $1 / 8$ & LDA \\
\hline & & Canada thistle & $1 / 4$ & LDA \\
\hline & & $\begin{array}{l}\text { other weed } \\
\text { species }\end{array}$ & $1 / 4$ & LDA \\
\hline 15 & $\begin{array}{c}\text { Amelia Island } \\
(238.8)\end{array}$ & $\begin{array}{l}\text { other weed } \\
\text { species }\end{array}$ & $1 / 4$ & LDA \\
\hline \multirow[t]{2}{*}{14} & \multirow[t]{2}{*}{ Rosebud, West (8.6) } & Canada thistle & $1 / 4$ & MD \\
\hline & & $\begin{array}{c}\text { Russian } \\
\text { knapweed }\end{array}$ & $1 / 64$ & VLD \\
\hline \multirow[t]{2}{*}{13} & \multirow[t]{2}{*}{ Rosebud, East (29) } & Canada thistle & $1 / 64$ & LDA \\
\hline & & $\begin{array}{c}\text { other weed } \\
\text { species }\end{array}$ & .5 & LDA \\
\hline 12 & Far West (32.8) & $\begin{array}{c}\text { other weed } \\
\text { species }\end{array}$ & $1 / 64$ & VLD \\
\hline 11 & Roche Juane (1) & $\begin{array}{l}\text { other weed } \\
\text { species }\end{array}$ & $1 / 16$ & LDA \\
\hline \multirow[t]{4}{*}{10} & \multirow[t]{4}{*}{ Kinsey Bridge (27.7) } & $\begin{array}{c}\text { Purple } \\
\text { loosestrife }\end{array}$ & $1 / 4$ & MD \\
\hline & & Field bindweed & $1 / 16$ & LDA \\
\hline & & Leafy spurge & $1 / 16$ & LDB \\
\hline & & $\begin{array}{l}\text { other weed } \\
\text { species }\end{array}$ & $1 / 2$ & LDA \\
\hline
\end{tabular}


Table 3. (cont.)

\begin{tabular}{|c|c|c|c|c|}
\hline $\begin{array}{l}\text { MAP KEY } \\
\text { NUMBER }\end{array}$ & $\begin{array}{l}\text { DFWP PROPERTY } \\
\text { NAME and ACREAGE }\end{array}$ & $\begin{array}{c}\text { WEED SPECIES } \\
\text { PRESENT } \\
\end{array}$ & $\begin{array}{l}\text { WEED } \\
\text { SIZE }^{1} \\
\end{array}$ & $\begin{array}{l}\text { SPECIES } \\
\text { DENSITY }^{2}\end{array}$ \\
\hline \multicolumn{5}{|c|}{ YELLOWSTONE RIVER DRAINAGE (cont.) } \\
\hline 9 & Bonfield (58) & $\begin{array}{c}\text { other weed } \\
\text { species }\end{array}$ & $1 / 8$ & LDA \\
\hline \multirow[t]{3}{*}{7} & \multirow[t]{3}{*}{ Fallon Bridge (5.34) } & Leafy spurge & 2 & LDB \\
\hline & & Canada thistle & $1 / 16$ & LDA \\
\hline & & $\begin{array}{c}\text { other weed } \\
\text { species }\end{array}$ & $1 / 16$ & $\mathrm{HD}$ \\
\hline 4 & Intake (52.6) & Leafy spurge & 3 & LDA \\
\hline 2 & $\begin{array}{c}\text { Sidney Bridge (3.3) } \\
\text { (site acquired, not } \\
\text { developed as of } \\
\text { plan date) }\end{array}$ & unknown & & \\
\hline \multirow[t]{2}{*}{1} & \multirow{2}{*}{$\begin{array}{l}\text { Diamond Willow } \\
(100)\end{array}$} & Canada thistle & 3 & LDB \\
\hline & & Field bindweed & 3 & LDA \\
\hline \multicolumn{5}{|c|}{ POWDER RIVER DRAINAGE } \\
\hline 22 & $\begin{array}{l}\text { Little Powder River (40) } \\
\text { leased, owner } \\
\text { responsible for } \\
\text { weed control }\end{array}$ & unknown & & \\
\hline 19 & Broadus Bridge (2.9) & unknown & & \\
\hline 8 & $\begin{array}{c}\text { Powder River Depot } \\
(2.4)\end{array}$ & Leafy spurge & 1.2 & LDB \\
\hline \multicolumn{5}{|c|}{ TONGUE RIVER DRAINAGE } \\
\hline \multirow[t]{2}{*}{18} & \multirow[t]{2}{*}{$\begin{array}{l}12 \text { Mile Dam } \\
(26.3)\end{array}$} & Canada thistle & $1 / 4$ & LDB \\
\hline & & $\begin{array}{l}\text { other weed } \\
\text { species }\end{array}$ & $1 / 8$ & LDA \\
\hline
\end{tabular}


Table 3. (cont.)

\begin{tabular}{|c|c|c|c|c|}
\hline $\begin{array}{l}\text { MAP KEY } \\
\text { NUMBER }\end{array}$ & $\begin{array}{c}\text { DFWP PROPERTY } \\
\text { NAME and ACREAGE }\end{array}$ & $\begin{array}{c}\text { WEED SPECIES } \\
\text { PRESENT } \\
\end{array}$ & $\begin{array}{l}\text { WEED } \\
\text { SIZE }^{1}\end{array}$ & $\begin{array}{l}\text { SPECIES } \\
\text { DENSITY' }\end{array}$ \\
\hline \multicolumn{5}{|c|}{ PONDS AND RESERVOIR'S } \\
\hline 3 & Gartside Dam (160) & Canada thistle & 1 & $\mathrm{MD}$ \\
\hline 5 & $\begin{array}{l}\text { Hollecker Pond (24.4) } \\
\text { leased, owner } \\
\text { responsible } \\
\text { for weed control }\end{array}$ & Canada thistle & $1 / 4$ & VLD \\
\hline \multirow[t]{2}{*}{6} & \multirow[t]{2}{*}{$\begin{array}{c}\text { Johnson Reservoir } \\
\text { (60) }\end{array}$} & $\begin{array}{c}\text { other weed } \\
\text { species }\end{array}$ & $1 / 16$ & LDA \\
\hline & & Canada thistle & 1 & LDA \\
\hline 20 & $\begin{array}{c}\text { Rush Hall Reservoir } \\
\qquad(24.8) \\
\text { leased, owner } \\
\text { responsible } \\
\text { for weed control } \\
\end{array}$ & \multicolumn{3}{|c|}{$\begin{array}{l}\text { Canada thistle } \\
\text { Leafy spurge }\end{array}$} \\
\hline \multirow[t]{3}{*}{17} & \multirow{3}{*}{$\begin{array}{c}\text { South Sandstone } \\
\text { Reservoir } \\
(360)\end{array}$} & Canada thistle & $1 / 32$ & LDA \\
\hline & & Field bindweed & $1 / 32$ & LDA \\
\hline & & $\begin{array}{l}\text { Spotted } \\
\text { knapweed }\end{array}$ & $1 / 64$ & VLD \\
\hline
\end{tabular}

1 Size - page 11

2 Density - page 11 
Table 4 Noxious weed species present and status on Department of Fish, Wildlife and Parks (DFWP) State Parks in Region 7.

\begin{tabular}{|c|c|c|c|c|}
\hline \multirow{3}{*}{$\begin{array}{c}\text { MAP KEY } \\
\text { NUMBER } \\
5\end{array}$} & \multirow{3}{*}{$\begin{array}{c}\text { DFWP PROPERTY } \\
\text { NAME and ACREAGE } \\
\text { Hell Creek (260) }\end{array}$} & \multirow{2}{*}{$\begin{array}{c}\text { WEED SPECIES } \\
\text { PRESENT } \\
\text { Canada thistle } \\
\end{array}$} & \multicolumn{2}{|c|}{$\begin{array}{c}\text { WEED SPECIES } \\
\text { SIZE }^{1} \text { DENSITY }^{2} \\
\end{array}$} \\
\hline & & & $1 / 4$ & HD \\
\hline & & $\begin{array}{c}\text { other weed } \\
\text { species }\end{array}$ & $1 / 16$ & LDA \\
\hline \multirow[t]{3}{*}{1} & \multirow[t]{3}{*}{ Makoshika (8832.4) } & Leafy spurge & 15 & $\mathrm{MD}$ \\
\hline & & Canada thistle & 1 & MD \\
\hline & & $\begin{array}{c}\text { other weed } \\
\text { species }\end{array}$ & 12 & LDA \\
\hline \multirow[t]{2}{*}{2} & \multirow{2}{*}{$\begin{array}{l}\text { Medicine Rocks } \\
\text { (320) }\end{array}$} & Canada thistle & $1 / 4$ & MD \\
\hline & & $\begin{array}{c}\text { other weed } \\
\text { species }\end{array}$ & $1 / 4$ & LDA \\
\hline \multirow[t]{3}{*}{3} & \multirow{3}{*}{$\begin{array}{l}\text { Pirogue Island } \\
\quad(210.3)\end{array}$} & Leafy spurge & 5 & $\mathrm{MD}$ \\
\hline & & Canada thistle & 2 & LDA \\
\hline & & $\begin{array}{c}\text { other weed } \\
\text { species }\end{array}$ & .5 & LDB \\
\hline \multirow[t]{5}{*}{6} & \multirow[t]{5}{*}{$\begin{array}{l}\text { Rosebud Battlefield } \\
\text { (3052) }\end{array}$} & $\begin{array}{c}\text { Spotted } \\
\text { knapweed }\end{array}$ & $1 / 8$ & LDB \\
\hline & & $\begin{array}{l}\text { Dalmation } \\
\text { toadflax }\end{array}$ & $1 / 16$ & LDA \\
\hline & & Common burdock & 30 & LDA \\
\hline & & Canada thistle & 30 & LDB \\
\hline & & $\begin{array}{c}\text { other weed } \\
\text { species }\end{array}$ & 3.5 & LDB \\
\hline 7 & $\begin{array}{c}\text { Tongue River } \\
\text { Reservoir (641.8) }\end{array}$ & $\begin{array}{l}\text { other weed } \\
\text { species }\end{array}$ & $1 / 8$ & LDA \\
\hline 4 & $\begin{array}{c}\text { Miles City } \\
\text { Fish Hatchery (245.6) }\end{array}$ & $\begin{array}{c}\text { other weed } \\
\text { species }\end{array}$ & 5 & LDB \\
\hline 4 & $\begin{array}{c}\text { Region Seven } \\
\text { Administrative Sites } \\
(7.6)\end{array}$ & none & & \\
\hline
\end{tabular}

1 Size - page 11

2 Density - page 11 
1 SIZE: total acres or partial acres for each species, respectively:
1 acre $=43,560 \mathrm{ft}^{2}\left(200^{\prime} \times 200^{\prime}\right)$
$1 / 2$ acre $=21,780 \mathrm{ft}^{2}$
$1 / 16$ acre $=2,722 \mathrm{ft}^{2}\left(50^{\prime} \times 50^{\prime}\right)$
$1 / 4$ acre $=10,890 \mathrm{ft}^{2}\left(100^{\prime} \times 100^{\prime}\right)$
$1 / 32$ acre $=1,361 \mathrm{ft}^{2}$
$1 / 8$ acre $=5,445 \mathrm{ft}^{2}$
$1 / 64$ acre $=680 \mathrm{ft}^{2}\left(25^{\prime} \times 25^{\prime}\right)$
$<1 / 64$ acre estimation in square feet

2 DENSITY: number of weed stems in the population, respectively:

VLD: very low density --one or a few individual plants, accounting for a very small proportion of the vegetative ground cover; native species well represented

LDA: low density - $A$--individual plants clumped in small areas, accounting for a small proportion of the vegetative ground cover; native species well represented

LDB: low density - B -- individual plants scattered throughout site, accounting for a small proportion of the vegetative ground cover; native species well represented

MD: moderate density --individual plants numerous, accounting for a moderate proportion of the vegetative ground cover; native species present

HD: high density --individual plants abundaint, accounting for a high proportion of the ground cover; native species present,but not well represented

VHD: very high density --individual plants very abundant, accounting for almost all of the vegetative ground cover; native species almost absent 


\subsection{Noxious Weed Management Goals}

Region 7's noxious weed management goals are derived from statutory requirements, DFWP policies, as well as ecological considerations. They are to:

- Meet legal requirements (including the County Noxious Weed Control Act and the Montana Environmental Policy Act) to manage plants declared as noxious weeds by the State and by the Big Horn, Carter, Custer, Dawson, Fallon, Garfield, Prairie, Richland, Rosebud and Treasure county weed boards.

- Develop and implement an integrated approach to noxious weed management and a strategy to prioritize treatment areas.

- Attempt to contain, reduce or eradicate weed populations depending on the location and status of the population.

- Prevent the introduction and establishment of new noxious weed species to the extent feasible.

- Work cooperatively with adjacent landowners and the County Weed Boards to enable consistent and sound weed management efforts.

- Conduct treatments in an ecologically responsible manner to maintain fish, wildlife, and vegetation resources and protect human health and safety.

- Involve the public in the planning process.

\subsection{Programs and Legal Framework Affecting Region 7's Weed Plan}

DFWP Region 7's implementation of its Plan is subject to the policies and programs of this and other agencies, as well as to state and federal laws. These are briefly discussed below.

\subsubsection{Wildlife Management Area Plans}

Site specific integrated resource management plans for the WMA's are in various stages of development and/or revision. These plans detail management objectives, current conditions, and strategies to meet desired future conditions. Noxious weed management is an element of these plans. Region 7's Plan identifies goals and treatment strategies for each WMA which are consistent with each Area Management Plan. 


\subsubsection{County Weed District 5-Year Plans}

The County Noxious Weed Control Act provides for the creation of County Weed Districts and a County Weed Board to implement noxious weed control programs within their respective counties. The Board is responsible for preparing a Plan which identifies noxious weeds requiring treatment in that county (including those county-declared species) and outlines procedures for control actions. DFWP is obliged to consult these plans. Also, the DFWP is committed to coordinating with local County Weed Boards. The kind of activities that typically require interagency coordination include release of biocontrol agents and "War on Weeds" community projects which are implemented with funds approved through the State's Noxious Weed Trust Fund Grant Program. Furthermore, DFWP has contracted with County Weed Districts over the years to conduct herbicide applications on some of its properties. Contracting will likely continue in the future, subject to a particular District having the time and personnel resources to accept such contracts.

\subsubsection{MT Legislature's House Bill \#395}

This Plan has also been prepared in anticipation of the encouragement state agency weed control efforts will receive from the 1995 Montana Legislature's House Bill \#395 (MCA 7 22-2151). The measure, in a broad sense, requires state agencies to enter into cooperative agreements with local weed district boards for the purpose of integrated noxious weed management on state lands. The measure also requires agencies to formulate 6 year weed management plans for lands administered by each agency. The DFWP R-7 Weed Management Plan will serve as the "umbrella" document for R-7's cooperative agreements and 6 year plans under (MCA 7-22-2151). This Plan and accompanying Environmental Assessment (EA) will provide the guidelines and objectives for weed control management, including treatments selected in the 6 year plans.

\subsubsection{Other Noxious Weed Management Plans}

The Montana Department of Transportation is developing a weed plan. This plan would have bearing on Region 7's program if road reconstruction activities occurred or if weed management efforts were completed on state highways that border Region 7 lands.

Noxious weed management on DFWP properties will be affected by the weed management activities of its neighbors. Some DFWP properties in Region 7 are bordered by the Bureau of Land Management (BLM). The BLM completed an Environmental Impact Statement (EIS) on noxious weed control in 1985.

DFWP Region 5, bordering Region 7 to the west, has already completed its Management Plan and EA process. Region 6, bordering Region 7 to the north, is in the process of developing a weed management plan. 


\subsubsection{Noxious Weed Trust Fund Environmental Impact Statement}

The Montana Department of Agriculture completed an EIS on the State's Noxious Weed Trust Fund Grants Program. If DFWP were to participate in any grant program, either as a sponsor or as a cooperator, DFWP's activities would be subject to the particulars of that document which include environmental review of proposed actions by MDA and fulfilling grant application requirements.

\subsubsection{Other Applicable Laws and Regulations}

- $\quad$ Federal Insecticide, Fungicide, Rodenticide Act (P.L. 92-516, FIFRA) and Code of Federal Regulations 40 CFR (Part 171).

- Montana Environmental Policy Act (MCA 75-1-101 et seq.) and rules (ARM 12.2.401 et seq.).

- Montana Weed Control Act (MCA 80-7-801 et seq.).

- Montana Water Quality Act (MCA 75-5-101 et seq.).

- Montana Agricultural Chemical Groundwater Protection Act (MCA 80-15-100 et seq.).

- Montana Pesticides Act (MCA 80-8-801 et seq.).

\subsection{Decisions to be Made}

In accordance with MEPA, this Draft Environmental Assessment identifies potential impacts on the natural and human environment that may result from the proposed action, implementation of the Noxious Weed Management Plan (based on the concept of Integrated Noxious Weed Management) or from the implementation of one of the reasonable Alternatives. It should provide the Region 7 Supervisor (decision maker) with adequate information to determine whether or not significant impacts would occur if the proposed action were to be implemented.

The Regional Supervisor must decide whether to continue to manage noxious weeds in the same manner and to the same extent as in the past (Status Quo Alternative), to accept one of the other three Alternatives presented in this document, or to accept one of the Alternatives with changes such as mitigation measures.

Once an Alternative is selected, the Regional Supervisor will decide whether or not the proposed action will have significant adverse impacts on the human and natural environments. If no significant adverse impacts would result, then the final EA will state the reasons for this finding and that the EA is the appropriate level of analysis. The Plan, 
revised to incorporate findings of the EA, would be implemented. Also, these findings would be articulated in the Decision Notice which completes the EA process. If impacts are judged to be significant, an EIS may be completed to further investigate the proposed action.

\subsection{Public Concerns and Issues}

Region 7 is the sixth out of eight DFWP regions to produce a region-wide weed management plan and environmental assessment. In an attempt to address some concerns prior to the public comment period for Region 7's draft documents, the following issues have been distilled from comment opportunities, public meetings and scoping sessions in other regions:

- What weed treatment methods does DFWP propose to use? How will these methods affect the natural and human environment?

- Herbicide use can have negative impacts if handled improperly or used in sensitive areas. What are the potential impacts to resources such as air, groundwater, surface water, fisheries, wildlife, wildlife habitat, and native plant communities? What are the potential impacts to recreationists and DFWP employees?

- Certain weed species have become established on Region 7 lands, while others have not. How will DFWP Region 7 prioritize treatment activities?

- The noxious weed problem does not stop at DFWP property boundaries. How will DFWP address weed problems on adjacent lands? How will DFWP work with other interested parties such as County Weed Boards, state and federal agencies, adjacent landowners, lessees, and volunteer groups?

- Poor land management practices such as those which extensively disturb the ground and soil surface facilitate noxious weed establishment. How will the DFWP monitor and modify these activities to curtail the spread of noxious weeds on its properties?

- Public education and awareness about noxious weeds and their management are very important. What role will DFWP have in public awareness? Also, what involvement will the public have in management decisions?

These issues are addressed herein, and the draft plan and environmental assessment will be publicized and made available for a 30-day public review and comment period. The documents will be available at FWP headquarters and regional offices, as well as at county libraries and weed district offices in the affected counties. If there is a significant amount of concern or opposition to the proposed alternative during the comment period, a public meeting will be held to hear and address any concerns. Following the review period, a Decision Notice will be issued incorporating comments and revisions. 


\subsection{TREATMENT METHODS AND ALTERNATIVES}

\subsection{Treatment Methods}

The noxious weed management goals of DFWP are to attempt to prevent the introductions of new noxious weed species and to discourage the spread of established species on DFWP properties. In discussing how to meet these goals, DFWP distinguishes between chemical and non-chemical treatment methods. These categories are outlined below. Various combinations of these methods are incorporated into the Alternatives which will be discussed subsequently.

\subsubsection{Chemical Methods}

Chemical treatment methods involve the use of herbicides to kill weeds directly or the application of soil sterilants which prevent the germination of noxious weed seeds. Over the past half-century, chemical herbicides have been developed to treat a variety of weed species. While the benefits of chemical methods include efficacy and low cost, there are valid concerns about any application of chemicals to the landscape.

The herbicides 2,4-D, picloram, glyphosate, and clopyralid are proposed for use on Region 7 lands. These herbicides may be used alone or in combination as recommended by label directions. Table 5 lists the chemicals and formulations proposed for use. Appendix A summarizes herbicide properties and lists the target noxious weed species and the efficacy of herbicide treatments. Other herbicides, which have been approved by the U.S. Environmental Protection Agency (EPA) and licensed for use in Montana, may be considered in the future as they become available.

Table 5. Herbicides proposed for use on Department of Fish, Wildlife and Parks Region 7 properties, registered trade name, and application rates on a per acre basis according to manufacturer label recommendations.

\begin{tabular}{lll}
\hline Common Chemical Name & Registered Trade Name & Application Rates \\
\hline 2,4-D amine & Weedar 64, various & $1-3$ quarts \\
picloram & Tordon $22 \mathrm{~K}$ & 1 pint -2 quarts \\
glyphosate & Ruler & 16 ounces -4 quarts \\
clopyralid & Stinger & $1 / 4-11 / 3$ pints \\
clopyralid & Transline & $1 / 4-11 / 3$ pints \\
clopyralid $+2,4-D$ & Curtail & $2-22 / 3$ pints \\
2,4-D ester & Hi-Dep, various & $1-3$ quarts \\
\hline
\end{tabular}


The use of herbicides would depend on the treatment objective, season of application, stage of plant growth, topography, species present, effectiveness of treatment, equipment limitations, and potential environmental impacts. Herbicide and application rate selection would depend on the target species, other vegetation present, presence of sensitive plant or animal species, soil type, presence of surface waters, wetlands, shallow groundwater or groundwater recharge areas, and proximity to human habitation or use sites. Appendix $\mathrm{H}$ in the Plan contains label instructions of each herbicide proposed for use.

Herbicides would always be applied according to manufacturer label directions, regardless of what Alternative is selected. Changes in application rates, recommended by research institutions, would be considered if these rates do not exceed label directions. Chemical applications would be supervised or conducted by licensed applicators and in compliance with Federal requirements.

Aerial applications of herbicide are not proposed for the property groups under this Plan. This is due to the small size and presence of surface water at the majority of the properties and the desired protection of recreation site values such as non-target vegetation, (for example cottonwood, Ponderosa pine and juniper trees and a multitude of shrub and forb species). Another significant consideration is the presence of plant species of special concern on a number of the properties.

Vehicle-mounted sprayer (hand gun or boom) applications will be used primarily in open areas that are readily accessible by vehicle. Boom sprayers, which are fixed, provide less flexibility and would be used only where feasible to treat concentrated weed patches. The hand gun would be used for spot treatment of weeds. Spot treatments would be selected over broadcast methods. Regardless of spray method used, sprays would be applied in a manner that gives the best possible coverage with the least amount of drift. Hand applications would utilize backpack spraying and wiper application. Backpack sprayers would be used on small or scattered patches in rough terrain or environmentally sensitive areas. Contact systemic herbicides, such as glyphosate, would be used to treat individual plants or for seed bed preparation.

Precautions for use would include:

- During application periods, weather conditions (including forecasted precipitation events) and temperatures would be monitored by contractors and weed management personnel.

- Calibration checks would be conducted, when feasible, to ensure that equipment is functioning correctly.

- Label requirements would be followed for all herbicide applications; further precautions may be determined to be necessary during the pre-treatment review process. 


\subsubsection{Non-Chemical Methods}

Manual methods involve grubbing or topping with hand tools and hand-pulling. These methods may effectively eradicate annual or biennial weed species in small or sparse populations, primarily by preventing seed production and distribution as long as treatment occurred prior to seed ripe. Annual re-treatment is required. Because these methods are labor intensive, their application would be limited primarily to environmentally or culturally sensitive areas and very small populations.

Cultural methods include mowing, tilling, reseeding, grazing, and other agricultural techniques. These methods may effectively reduce some noxious weed species, although implementation is often limited by topography and access. These methods can be costly and time consuming. Furthermore, disruption of the soil surface may create new microsites vulnerable to noxious weed encroachment. Burning, as a weed treatment method by itself, is generally of limited effectiveness.

Biological methods describe the introductions of host-specific natural enemies (insects or pathogens) on individual plants within a noxious weed population. Biological control agents can effectively stress noxious weeds and reduce seed production and viability. Use of biocontrol agents would not eliminate the species but can reduce the population to a tolerable level, particularly when used in combination with other treatment methods. Biological control may be the only method possible in some areas. These areas may include those that are inaccessible to mowers or where other treatment methods are not possible or cost effective to implement. Initial acquisition costs of biocontrol agents are high. However, as populations establish themselves on a site, insects can be collected and released to other sites.

\subsection{Description and Comparison of the Alternatives}

Four Alternatives for noxious weed management were considered. They are: Status Quo, Integrated Noxious Weed Management, Chemical Methods, and Non-Chemical Methods. The MEPA requires the consideration of a "No Action" alternative in which the proposed action (management of noxious weeds in this case) does not take place. However, under the County Noxious Weed Control Act, DFWP is legally required to manage noxious weeds on its properties, as any other landowner in Montana. Thus, the "No Action" alternative is not meaningful in the context of noxious weeds and will not be considered per se. Instead, DFWP will consider the implementation of a "Status Quo" Alternative in which there is no change in the current management program. Four Alternatives for noxious weed management are described below. Each Alternative incorporates some or all of the treatment methods available: manual, cultural, biological, and chemical. However, each Alternative, in emphasizing a different method(s), would have different potential impacts to air quality, soils, water quality, wildlife/fisheries, vegetation, recreation, human health, and cultural/historic resources. Chapter 3.0 discloses these impacts. 


\subsubsection{Alternative 1 (Status Quo)}

Under Alternative 1 (Status Quo), noxious weed management would continue along the course set over the past several years. Previous weed treatment activities in Region 7 included an emphasis on chemical methods, with some use of manual, cultural, and biological methods. Under this Alternative, no particular effort to integrate noxious weed management with other resource management programs would be made, nor would we plan a coordinated effort to manage noxious weeds. Field personnel would simply react to weed outbreaks as they occurred. Under this Alternative, chemicals methods would still be applied according to manufacturer label instructions, but the additional safeguards outlined in the Noxious Weed Management Plan would not be implemented. Biological control agents already introduced would run their courses, but insect populations would not be supplemented or redistributed to any great degree. Periodic consultation with County Weed Boards would occur but active participation in new, coordinated treatment initiatives or public awareness programs would not.

If this Alternative is selected, then.noxious weeds would likely spread on and from Region 7 lands because this Alternative does not describe a proactive management strategy. Weed-free areas would likely be encroached upon as noxious weed seed reserves build up and species spread to ecological tolerance. This Alternative would not adequately protect state resources nor would DFWP management goals and stewardship responsibilities be met. The potential loss of wildlife forage, the change in vegetation communities, and decreases of aesthetic quality would be significant.

\subsubsection{Alternative 2 (Integrated Noxious Weed Management)}

This Alternative calls for a program which integrates preventive measures with biological, manual, cultural, and chemical treatment methods in a proactive fashion. The Plan details this approach, defined as Integrated Noxious Weed Management. Its goal is the long-term prevention and reduction of noxious weeds from DFWP properties, whether for established populations or new ones. This approach permits consideration of and planning for other resource management objectives.

Alternative 2 provides the best opportunity for long-term weed management with minimal impact to the environment. The Plan promotes flexibility during the treatment design and planning processes. It allows a variety of treatment methods to be used as site-specific conditions warrant and incorporates many additional safeguards to ensure that other resources are not adversely affected by noxious weed treatment. Herbicide use would still present some risks, but they would be considerably less than those expected under other Alternatives. If this Alternative is selected, prospects for long-term prevention and reduction of noxious weeds on DFWP properties are good -- while at the same time preserving other resources. 


\subsubsection{Alternative 3 (Chemical Methods)}

Chemical herbicides would be the primary treatment method except where there is a high risk of environmental contamination or label directions preclude the use of herbicides. Biological control agents (insects and pathogens) already introduced would be permitted to run their course, but new introductions or re-distributions would not take place since herbicides may limit the viability and success of biocontrol agents. Manual or cultural treatment methods would not be considered. Measures to help prevent noxious weed encroachment could still be implemented.

Under this Alternative, the risk of environmental contamination through chemical overapplication or accidental spill is highest, as is the chance of adversely affecting non-target plant or animal species. This would not be due to willful misuse, but rather because the total amount of chemicals used would be significantly higher under this Alternative than any other. Cumulative effects of chemical applications may occur if adjacent landowners also apply herbicides regularly. Ground and surface water and the associated resources would be at greatest risk. Concerns for human health are the greatest under this Alternative.

If this Alternative is selected, prospects for long-term reduction are good because chemicals are generally effective. However, chemical applications would be precluded in some settings because of manufacturer label restrictions (e.g. riparian zones). Thus, noxious weeds would persist in such settings. In general, the integrity of other resources can not be guaranteed under this Alternative since the primary objective is the reduction of noxious weeds through chemical methods.

\subsubsection{Alternative 4 (Non-Chemical Methods)}

Weed management emphasis would be toward containment of current weed populations. This Alternative emphasizes manual, cultural, and biological control methods. Herbicides would not be used, nor would DFWP Region 7 participate in cooperative programs which use or emphasize herbicides. Biological control methods would be accentuated and new pathogens would be introduced as they become available. Preventive methods that would not require major new funding by Region 7 could be implemented.

If this Alternative is selected, prospects for long-term success would be good only in areas where weeds patches are relatively small or well-confined and the rate of weed spread is relatively slow. Biological control treatments would have some impact on rate of spread but many researchers believe that more organisms (insects and pathogens) need to be developed and introduced to make biological control an effective tool (Story 1989). Also, several Region 7 properties are too small to sustain biocontrol organisms. In areas where populations are large or weed plants are well established with a seed source, prospects for long-term success under this Alternative are poor. The rate of spread will likely out-pace treatment activities. Coordination with adjacent landowners would be essential for this Alternative to be even marginally successful. 


\subsection{The Preferred Alternative}

The preferred Alternative, Integrated Noxious Weed Management (INWM), is briefly described below. The reader is referred to the Plan for a more detailed discussion. Some elements of Alternative 2 are also incorporated under Alternatives 1, 3, and 4.

DFWP's strategy is to employ the concept of INWM, as defined in the Plan. This concept is a systems approach to reduce pest damage to tolerable levels. This strategy seeks to tailor weed management activities to the treatment needs and site characteristics of a particular weed patch. First, weed management and treatment priorities are established. Then, treatment methods and techniques are selected, including natural predators and parasites, environmental modifications, and herbicides when necessary and appropriate. This approach allows the most flexibility for managing noxious weeds as site conditions change, treatment techniques improve, and funding opportunities arise. This approach is consistent with state law and the noxious weed plans developed by the counties.

\subsection{Cumulative Effects and Irreversible or Irretrievable Commitments}

In order to evaluate potential cumulative impacts to the environment, similar actions of adjacent landowner, federal, state, and county weed control boards would need to be considered. Of primary concern would be the potential cumulative effects on ground and surface waters resulting from herbicide application. Without coordinated efforts (communication, planning, and monitoring) contamination is possible.

The irreversible commitment of resources refers to the consumption or loss of resources that cannot be reversed, except possibly in the extreme long term. In the broadest sense, none of these Alternatives would result in the irreversible commitment of resources. However, some rare plant populations could be lost if proper mitigation measures are not followed, as would be the case under Alternatives 1, 3, and 4. Alternative 2 (INWM) is the only Alternative requiring such safeguards as sensitive plant inventory prior to chemical or cultural treatment activities.

The irretrievable commitment of resources refers to the consumption or loss of resources for a short period of time such as 50 to 100 years. In the absence of all noxious weed management activities, wildlife cover and forage, recreation values, and aesthetic values could be irretrievably committed. Continuation of the current management direction (Alternative 1, Status Quo) could result in the continued spread of noxious weeds and further alteration of resources that DFWP is charged to maintain or enhance. Under Alternatives 1,3 , and 4 , some rare plant populations could be impacted by treatment activities if proper mitigation measures are not followed. Only Alternative 2 (INWM) includes safeguards and guidelines to prevent the irretrievable commitment of resources or loss of rare plant populations. 


\subsection{THE AFFECTED ENVIRONMENT AND ANALYSIS OF POTENTIAL IMPACTS}

This chapter provides the basis for comparing the Alternatives presented in Chapter 2. Based on the issues identified in Section 1.6, this section of the EA describes the natural resources that may be affected by implementation of the preferred Alternative or one of the other Alternatives. Potential impacts are addressed in two ways and analyzed in relation to the treatment methods proposed under each Alternative. First they are discussed generally for all Region 7 properties and for each Alternative because most impacts could - occur on any site. Secondly, site specific impacts are discussed where specific resources may be negatively affected or where site conditions or characteristics may affect program implementation. The impacts of allowing noxious weeds to spread are also addressed. Table 6 summarizes the environmental impacts resulting from the selection of the preferred Alternative, or implementation of the Plan which emphasizes the concept of Integrated Noxious Weed Management.

Table 6. Summary of potential environmental impacts resulting from the implementation of the Noxious Weed Management Plan, emphasizing the concept of Integrated Noxious Weed Management

\begin{tabular}{|c|c|c|c|c|c|}
\hline & Unknown & None & Minor & $\begin{array}{l}\text { Poten- } \\
\text { tially } \\
\text { Signifi- } \\
\text { cant }\end{array}$ & $\begin{array}{c}\text { Can Impact } \\
\text { Be } \\
\text { Mitigated }\end{array}$ \\
\hline $\begin{array}{l}\text { 1. LAND RESOURCES Will the proposed action result in: } \\
\text { a. Soil instability or changes in geologic substructures? } \\
\text { b. Disruption, displacement, erosion, compaction, moisture loss, or over-covering } \\
\text { of soil which would reduce productivity or fertility? } \\
\text { c. Destruction, covering or modification of any unique geologic or physical } \\
\text { features? } \\
\text { d. Changes in siltation, deposition or erosion patterns that may modify the channe } \\
\text { of a river or stream or the bed or shore of a lake? } \\
\text { e. Exposure of people or property to earthquakes, landslides, ground failure, or } \\
\text { other natural hazards? }\end{array}$ & & $\begin{array}{l}X \\
X \\
X\end{array}$ & $\begin{array}{l}X \\
X\end{array}$ & & $\begin{array}{l}\text { yes }^{1} \\
\text { yes }^{1}\end{array}$ \\
\hline
\end{tabular}




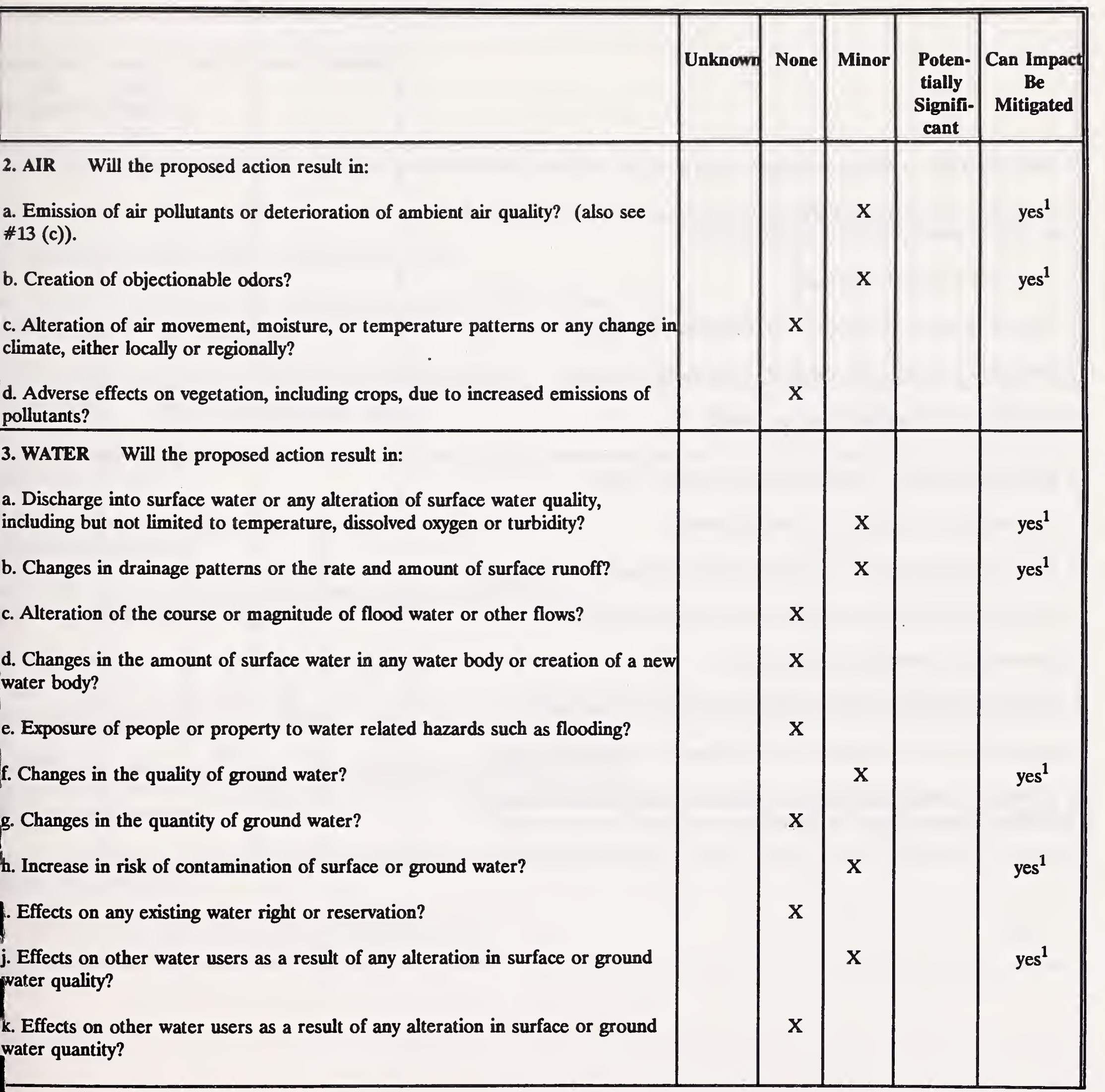




\begin{tabular}{|c|c|c|c|c|c|}
\hline 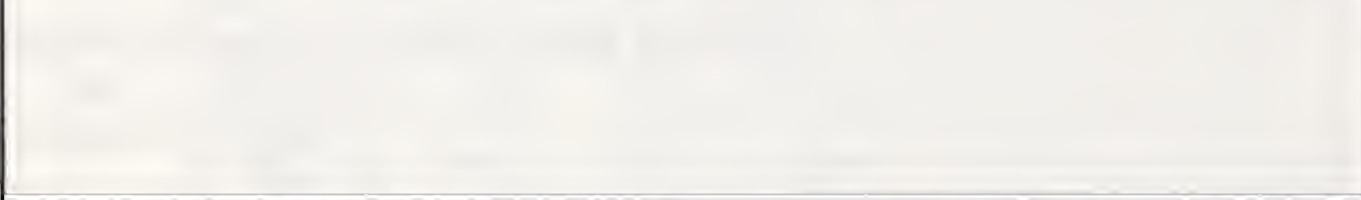 & Unknown & None & Minor & $\begin{array}{c}\text { Poten- } \\
\text { tially } \\
\text { Signifi- } \\
\text { cant }\end{array}$ & $\begin{array}{c}\text { Can Impact } \\
\text { Be } \\
\text { Mitigated }\end{array}$ \\
\hline $\begin{array}{l}\text { 4. VEGETATION Will the proposed action result in: } \\
\text { a. Changes in the diversity, productivity or abundance of plant species (including } \\
\text { trees, shrubs, grass, crops, and aquatic plants)? } \\
\text { b. Alteration of a plant community? } \\
\text { c. Adverse effects on any unique, rare, threatened, or endangered species? } \\
\text { d. Reduction in acreage or productivity of any agricultural land? } \\
\text { e. Establishment or spread of noxious weeds? }\end{array}$ & & $\mathrm{x}$ & $\begin{array}{l}x \\
x \\
x\end{array}$ & & $\begin{array}{l}\text { yes }^{1} \\
\text { yes }^{1} \\
\text { yes }^{1}\end{array}$ \\
\hline $\begin{array}{l}\text { 5. FISH/WILDLIFE Will the proposed action result in: } \\
\text { a. Deterioration of critical fish or wildlife habitat? } \\
\text { b. Changes in the diversity or abundance of game animals or bird species? } \\
\text { c. Changes in the diversity or abundance of nongame species? } \\
\text { d. Introduction of new species into an area? } \\
\text { e. Creation of a barrier to the migration or movement of animals? } \\
\text { f. Adverse effects on any unique, rare, threatened, or endangered species? } \\
\text { g. Increase in conditions that stress wildlife populations or limit abundance } \\
\text { (including harassment, legal or illegal harvest or other human activity)? }\end{array}$ & & $\begin{array}{l}\mathrm{X} \\
\mathrm{X} \\
\mathrm{X} \\
\mathrm{X} \\
\mathrm{X}\end{array}$ & $\mathrm{x}$ & & yes $^{1}$ \\
\hline
\end{tabular}




\begin{tabular}{|c|c|c|c|c|c|}
\hline & Unknown & None & Minor & $\begin{array}{l}\text { Poten- } \\
\text { tially } \\
\text { Signifi- } \\
\text { cant }\end{array}$ & $\begin{array}{c}\text { Can Impact } \\
\text { Be } \\
\text { Mitigated }\end{array}$ \\
\hline $\begin{array}{l}\text { 9. COMMUNITY IMPACTS Will the proposed action result in: } \\
\text { a. Alteration of the location, distribution, density, or growth rate of the human } \\
\text { population of an area? } \\
\text { b. Alteration of the social structure of a community? } \\
\text { c. Alteration of the level or distribution of employment or community or personal } \\
\text { income? } \\
\text { d. Changes in industrial or commercial activity? } \\
\text { e. Changes in cultural diversity or uniqueness? } \\
\text { f. Increased traffic hazards or effects on existing transportation facilities or } \\
\text { patterns of movement of people and goods? }\end{array}$ & & $\begin{array}{l}X \\
X \\
X \\
X \\
X \\
X\end{array}$ & & & \\
\hline $\begin{array}{l}\text { 10. PUBLIC SERVICES/TAXES/UTILITIES } \\
\text { a. Will the proposed action have an effect upon or result in a need for new or } \\
\text { altered governmental services in any of the following areas: fire or police } \\
\text { protection, schools, parks/recreational facilities, roads or other public facility } \\
\text { maintenance, water supply, sewer or septic systems, solid waste disposal, health, on } \\
\text { other governmental services? If any, specify. }\end{array}$ & & $X$ & & & \\
\hline $\begin{array}{l}\text { b. Will the proposed action have an effect upon the local or state tax base and } \\
\text { revenues? } \\
\text { c. Will the proposed action result in a need for new facilities or substantial } \\
\text { alterations of any of the following utilities: Electric power, natural gas, other fuel - } \\
\text { supply or distribution systems, or communications? } \\
\text { d. Will the proposed action result in increased use of any energy source? }\end{array}$ & & $X$ & & & \\
\hline
\end{tabular}


11. AESTHETICS/RECREATION Will the proposed action result in:

a. Alteration of any scenic vista or creation of an aesthetically offensive site or effect that is open to public view?

b. Alteration of the aesthetic character of a community or neighborhood?

c. Alteration of the quality or quantity of recreational opportunities and settings?

12. CULTURAL/HISTORIC RESOURCES Will the proposed action result in:

a. Destruction or alteration of any site, structure or object of prehistoric, historic, or paleontological importance?

b. Physical change that would affect unique cultural values?

c. Effects on existing religious or sacred uses of a site or area?

\section{SUMMARY EVALUATION OF SIGNIFICANCE}

Does the proposed action, considered as a whole:

a. Have impacts that are individually limited, but cumulatively considerable? (A project may result in impacts on two or more separate resources which create a significant effect when considered together or in total.)

b. Involve potential risks or adverse effects which are uncertain but extremely hazardous if they were to occur?

c. Potentially conflict with the substantive requirements of any local, state, or federal law, regulation, standard or formal plan?

d. Establish a precedent or likelihood that future actions with significant environmental impacts will be proposed?

e. Generate substantial debate or controversy about the nature of the impacts that would be created?

Mitigative measures outlined in the Department of Fish, Wildlife and Parks Noxious Weed Management Plan, Region 7 (1996). 


\subsection{Air Quality}

\subsubsection{Current Conditions}

Air quality in Montana is regulated through the Federal Clean Air Act and the Montana Clean Air Act. These laws establish ambient air quality and emission standards. Herbicides themselves are not regulated under the Federal Clean Air Act. Air quality within Region 7 is generally very good. However, localized high winds may create localized high particulate counts.

Other areas in southeast Montana have intermittent minor conditions that may cause temporary pollution problems but are not persistent and do not exceed federal and state standards.

\subsubsection{Analysis of Potential Impacts}

\section{General}

Chemical treatment methods have the potential to affect air quality when chemical particles are suspended in the atmosphere. Impact severity depends on the type of chemical, the chemical concentration, and the duration of suspension. The drift of airborne spray particles may adversely affect air quality depending on the size of the particle and wind conditions. These effects are expected to be short-term.

Cultural treatment methods could temporarily increase dust levels if large areas were mowed, tilled, or reseeded. Biological and manual methods would not affect air quality. Overall, air quality would not be significantly affected by implementation of any of the Alternatives. Under Alternative 1 (Status Quo), Alternative 2 (Integrated Noxious Weed Management) and Alternative 3 (Chemical Methods), there would be short-term, minor effects associated with chemical odors in the immediate vicinity of a spray site. Chemical odors, resulting from a petroleum-based carrier medium in the herbicide, are released during the application process and could be perceived as unpleasant or offensive. The amount of chemical in the air would be elevated for only a short time. Additionally, some spray particles would drift away from the application location. Only Alternative 2 (Integrated Noxious Weed Management) minimizes these short-term impacts since guidelines for chemical applications (beyond those included on manufacturer labels) are included in the Plan. The Plan specifies that applications would be conducted when weather conditions (wind speed and turbulence) are suitable, nozzles on spray equipment would be adjusted to prevent aerosol dispersion, and herbicide formulations with relatively low volatility would be used. Alternatives 2 (Integrated Noxious Weed Management) and 4 (Non-Chemical) may increase dust levels as a result of cultivation or other agricultural practices which disrupt soils. 


\section{Site Specific Impacts}

Region 7 properties that may be more significantly affected by changes in air quality would include those sites used frequently by the public or DFWP employees. Examples include Makoshika SP, Tongue River SP, and any of the FAS's within a short drive of a major population center. Determining when low public use periods occur (for example, time of day or day of the week) at a particular site and restricting spray activities to those periods would reduce the potential for impact. Private property owners with residences near DFWP property boundaries may also be affected by chemical treatments.

\subsection{Geology and Soils}

\subsubsection{Current Conditions}

Southeast Montana has a diverse geologic history. The landscape has been shaped by depositional, erosional, and glacial forces. As such, the geology and soils of the region are highly variable. Soil profile characteristics vary widely. Soils may be coarse or fine textured, falling into various classifications of sandy, silty, or clayey.

Some DFWP sites have soils that are wet much of the year or have a water table within five feet of the surface. They are associated with rivers, lakes, reservoirs and depressions where groundwater is near the surface, where "perched" water tables occur in clayey soils, or where irrigation practices maintain an elevated water table.

\subsubsection{Analysis of Potential Impacts}

\section{General}

Soils could be adversely affected under all Alternatives. The nature and extent of these impacts vary for each Alternative, depending on the method of noxious weed treatment emphasized. Soil properties themselves may dictate the feasibility of certain treatment methods.

Soil loss and reduced site productivity are the primary concerns with non-chemical treatment methods. Cultural treatments such as mowing and livestock grazing may involve a certain level of ground disturbance. This could reduce vegetative cover and expose the soil surface, making it susceptible to wind and water erosion. These activities could also cause soil compaction which would increase the potential for surface run-off as well as reduce the infiltration of water necessary for revegetation. Tilling and reseeding may leave soils temporarily exposed and more susceptible to erosion by wind and water or to subsequent noxious weed encroachment. Manual treatment methods could also reduce vegetative cover, with similar results. Biological methods are not expected to affect soils (BLM 1985). 
Potential impacts to soils from chemical application include the accumulation of chemical residues (loading), the alteration of soil flora and fauna, and an increase in salt content. Soil contamination through loading is the primary concern with chemical treatment methods. The magnitude of impacts depends on several properties related to both the herbicide and the soil environment. Appendix A summarizes pertinent herbicide properties in soils.

Little is known of the consequences of chemical loading in Montana soils, although it's most likely to occur when persistent herbicides are used repeatedly (Sparks 1989). The breakdown and movement of herbicides in soil is influenced by chemical, physical, and microbial processes. By remaining in the soil environment, persistent herbicides can provide residual weed treatment for up to five years depending on the soil conditions and the herbicide. During that time there is the potential for herbicides to be transported within and between soil layers. Watson et al. (1989) documented movement of picloram to increased soil depth as application rate increased. Furthermore, 365 days after the application, the chemical was still detectable.

Herbicides which target broadleaf plants tend to give a competitive advantage to grass species. However, if grass populations are slow to recover, the soil surface may be exposed, thus increasing the erosion potential. The litter layer created by dead plant material may offset increased erosion risks by mitigating raindrop impact and promoting infiltration. No evidence was found showing that herbicide use adversely affects soil organisms over the long-term (Audus 1976).

Under Alternative 1 (Status Quo), chemical applications would continue at their current intensity levels. Potential impacts would be those described above. The impacts may be more pronounced under this Alternative because chemical applications would proceed according to manufacturer label instructions without any additional safeguards, as would be the case under Alternative 2 (INWM). Noxious weeds would likely continue to proliferate and spread. Furthermore, if weeds become well established, a monoculture may result if weeds out-compete all other species. This, in turn, would increase the exposure of soil surfaces and cause an increase in soil erosion. (Rice et al. 1992).

Under Alternative 2 (INWM), the risk of soil contamination due to over-application of herbicides would be greatly reduced because other treatment methods would also be used. In addition, the concept of INWM tailors a treatment strategy to a particular site and its noxious weed status; thus, chemicals would not be applied in marginal settings where labei instructions permit use but other resources values dictate otherwise. Under this Alternative, all chemical treatments would take place under the guidelines presented in the Plan. Impacts from manual and cultural methods would be related to alteration of vegetative cover and exposure of the soil surface, as described above. 
Alternative 3 (Chemical Methods) entails the management of noxious weeds through the exclusive use of chemicals. The greater use of chemicals, especially those that are relatively persistent (e.g. picloram), could lead to chemical loading and thus soil contamination. In addition, since chemicals would be the only method of treatment, there would be a greater risk of a chemical spill with the increased handling and transport under this Alternative. If non-target species are affected to a significant degree, the overall reduction in vegetative ground cover may increase exposure of the soil surface with the aforementioned potential outcomes.

Alternative 4 (Non-Chemical Methods) would eliminate the potential for herbicide impacts to soils. However, as discussed above, manual and cultural treatments may cause erosion and productivity losses.

\section{Site Specific}

Increased erosion could occur on any DFWP site. Likewise chemical applications could cause the impacts described above on any site. Impacts to soil resources would be most pronounced on those sites where soils are fragile and/or not well-developed. All of the Alternatives could lead to erosion or soil contamination. However, each Region 7 site would be susceptible to erosion if noxious weeds are allowed to proliferate.

\subsection{Groundwater}

\subsubsection{Current Conditions}

Groundwater is an important resource. In addition to agriculture and commercial industries, it is used for municipal and rural residential purposes. Across Montana, 96\% of the public water supplies are derived from groundwater (Montana Department of Health and Environmental Sciences [DHES] 1992). Groundwater is also important because of its interaction with surface waters through recharge areas. In fact, most perennial streams in Montana are recharged by groundwater. Thus, maintaining groundwater purity is important for many reasons. With localized exceptions, groundwater quality in Region 7 is good.

\subsubsection{Analysis of Potential Impacts}

\section{General}

Herbicides can impact groundwater through point source discharges (e.g. accidental spills, uncontrolled releases during mixing, or releases at storage facilities). These impacts are often more severe than those of non-point source discharges. Deluca et al. (1989) documented contamination of domestic water supplies from point source discharges. 
Non-point source releases of herbicides also have the potential to contaminate groundwater. Seven pesticides have been detected in groundwater studies in Montana. Of the seven, only 2,4-D and picloram are proposed for use on DFWP Region 7 properties. Detection levels for all seven pesticides were below established health protection levels (DHES 1992). Leaching, one type of non-point source release, may result from either the one-time application of a chemical unsuitable for the particular soil type or location or from the repeated application of chemicals to specific areas (loading). Several factors influence this occurrence. These include the herbicide's behavior in soil (i.e. persistence, mobility, adsorption, and microbial degradation), soil properties (texture, permeability, organic matter content, and depth), water solubility, depth to groundwater, and precipitation. Appendix A summarizes general herbicide properties for the proposed active ingredients. A brief summary of research findings to date for herbicides proposed for use on Region 7 properties follows.

The half-life of a herbicide is the time required for half the amount of the active chemical ingredients to become inert through degradation by natural processes. Half-life depends on application rate and the environment to which the chemical is introduced. According to the pesticides background statements put out by the U.S. Department of Agriculture [USDA] (1984), picloram can have a half-life of more than four years in arid regions and approximately one month under conditions of moist soils with a high organic matter content. This relatively long persistence in soil and a poor affinity to soil (Watson et al. 1989), could result in leaching if picloram is applied to shallow groundwater areas (within 10 feet of the surface) and/or highly permeable soils. Studies of various soil types indicate that picloram is usually confined to the upper 1 foot $(30 \mathrm{~cm})$ when application rates are low (less than 1 $\mathrm{lb} / \mathrm{acre}$ ) (USDA 1984, Rice et al. 1992). However, at rates of 3 to $9 \mathrm{lb} / \mathrm{acre}$, picloram can readily move to depths greater than 3 feet (approximately 1 meter), even in relatively arid regions. The Plan recommends the Tordon $22 \mathrm{~K}^{\circ}$ formulation of picloram, which suggests rates of $1 \mathrm{lb} /$ acre or less for broadleaf weeds on non-cropland, range, and pasture. Use would be precluded on lands with water tables that reach to within 5 feet of the soil surface.

Lateral movement of picloram has been reported in soils (National Research Council of Canada 1977). Also of concern are soils which are within 20 inches of bedrock. Soils "saturated" with herbicide could potentially leach through to bedrock, migrate along the bedrock surface, and arise downslope in off-target areas. Also, bedrock fissures could become conduits moving herbicides to groundwater. The extent to which this could occur is unknown.

Clopyralid persists for one to three months. Rice et al. (1992) found that clopyralid applied at rates of $<1 \mathrm{lb} /$ acre in bunchgrass communities did not persist for more than one year nor was the herbicide detectable below $25 \mathrm{~cm}$. Because its adsorption to soil is low, leaching potential and mobility of clopyralid is high. The primary method of degradation is microbial activity in the soil; photo degradation is insignificant (Colby et al. 1989). 
With a persistence of one to four weeks, 2,4-D is rapidly degraded by soil microbial activity. Photo degradation is minor. Since 2,4-D adsorption to soil is only moderate, it has a relatively high mobility and a moderate leaching potential (BLM 1985).

Glyphosate persists for up to one month. Glyphosate is readily adsorbed by soils, but microbial degradation of the chemical is slow. Leaching potential is low, but the potential for surface run-off is high (Colby et al. 1989).

Under Alternative 1 (Status Quo), herbicide use would continue at current levels of intensity. There would be a moderate risk for herbicide contamination of groundwater because herbicides with moderate to high leaching potential (2,4-D, clopyralid, and picloram) would still be used by DFWP. The additional safeguards proposed in the Plan, however, would not be implemented. Biological control agents already introduced would not affect groundwater sources.

Under Alternative 2 (INWM), there is the potential to contaminate groundwater because herbicides with moderate to high.leaching ability (picloram, 2,4-D, and clopyralid) would be used. However, the chemical applications would be conducted as specified by guidelines outlined in the Plan. The non-chemical treatment methods (cultural, biological, and manual) incorporated into this Alternative would not impact groundwater.

Alternative 3 (Chemical Methods) emphasizes herbicide use. Because this Alternative would increase the total volume of herbicides released into the environment, it presents the greatest risk to groundwater resources. Herbicide use would be outright prohibited in a number of settings because of the extent of sensitive groundwater areas, resulting in the proliferation of noxious weeds at these sites.

Alternative 4 (Non-Chemical Methods) would not affect groundwater resources associated with Region 3 properties.

\section{Site Specific}

To assess potential risks to groundwater on specific sites from chemicals, a procedure originally developed for the Lewis \& Clark County Conservation District could be used in Region 7 (Lacey 1991). Risk of chemical contamination is determined for a site based on depth to seasonal or permanent water table, soil permeability, organic matter content, flooding hazard, and percent slope. A risk index based on these variables would be calculated on a scale between 1 and 100 and divided into four categories or classes of risk. Risk factors and classes would then be assigned to a soil map unit prepared by the Soil Conservation Service. This procedure could be implemented in the future as soil mapping is completed in the Region 7 area. 
Due to the interplay between surface and groundwater and the high variability in soil textures of river floodplains in southeast Montana, Fishing Access Sites would be of concern as well. Furthermore, groundwater is used as a public drinking water supply on 5 DFWP properties in Region 7. They are:

\section{Tongue River SP \\ Makoshika SP \\ Intake FAS}

Medicine Rocks SP

South Sandstone Reservoir FAS

Broadscale applications with high herbicide rates are not recommended on these sites. Decreasing application frequencies and reducing the concentration of active ingredient in herbicide formulations would also reduce contamination risks.

\subsection{Surface Water}

\subsubsection{Current Conditions}

Many of the properties administered by DFWP in Region 7 are associated with surface waters and have high recreation values associated with them. Surface water quality in Montana is regarded as generally good. This is also true in Region 7. Properties in Region 7 located on state classified waters are on the Yellowstone, Tongue, Powder and Missouri Rivers. The Yellowstone and Missouri Rivers are classified B-3, the Tongue River B-2, and the Powder River C-3. Waters classified as B-3 are suitable for drinking, culinary and food processing purposes after conventional treatments. Waters classified as B-3 are suitable for bathing, swimming and recreation; growth and propagation of non-salmonid fishes and associated aquatic life, waterfowl and furbearers; and agricultural and industrial water supply.

Waters classified as B-2 are similar to B-3, except they are marginally suitable for growth and propagation of salmonid fishes. Waters classified as $\mathrm{C}-3$ are unsuitable for growth and propagation of salmonid fishes and only marginally suitable for other uses.

The Yellowstone, Missouri, Tongue, and Powder Rivers fully support the designated uses. Infrequent departures do not affect designated uses. Several communities, including Miles City and Glendive, utilize the Yellowstone River for community water supplies. 


\subsubsection{Analysis of Potential Impacts}

\section{General}

There is public and agency concern for chemical contamination of the environment, in general and water resources, in particular. Herbicides may reach surface waters through non-point sources such as surface runoff, groundwater discharge, spray drift, and erosion of soil containing herbicides. Point source releases may occur during cleaning, mixing or loading activities or from accidental spills. One other avenue of water contamination stems from the potential for cumulative impacts to surface water quality through repeated chemical treatment of a particular site.

The potential for non-point source discharge of herbicides to surface waters is a function of herbicide characteristics, application rate, soil type, slope, vegetation, the length of time between application and rainfall, and the presence or absence of an untreated buffer between the application site and surface water. Picloram and 2,4-D have both been reported to enter surface water through runoff (MDA 1991). However, a study conducted under field conditions by EPA measured runoff of picloram a short distance downstream from the application site. The authors concluded that picloram does not present a serious threat to surface water quality (Evans and Dvseja 1973). Because the characteristics of clopyralid are similar to picloram, the runoff potential of clopyralid should be similar. The chemical glyphosate strongly adsorbs to soil particles and would be unlikely to enter surface waters through leaching. However, erosion of soil particles themselves to surface waters may cause the introduction of glyphosate after a precipitation event.

Little surface water contamination due to herbicide run-off from treated areas would be expected after major or minor storm events. After major storm events, instream dilution rates would be greatly enhanced whereas, during a minor storm event, runoff would be insufficient to mobilize any herbicides not bound to vegetation or soils. Sassman et al. (1984) found that the highest potential for herbicide contamination via run-off occurred when a moderate-sized storm event happened shortly after an area had been treated. In these situations, they found as much as three percent of the chemical applied to the watershed entered surface waters. However, in a highly porous, granitic watershed in Montana Watson et al. (1989) was unable to detect any picloram in surface waters during 90 days of monitoring after application of $1 \mathrm{lb} /$ acre of this herbicide.

Aerial drift has the lowest potential to cause measurable contamination of surface water. At the application rates proposed, incidental drift into water bodies would result in very low, usually undetectable, instream or in-lake concentrations of these substances. Furthermore, if label instructions are followed and treatment areas are carefully planned with use of buffer zones, even incidental drift into surface waters should not occur. 
Point source discharge from accidental chemical spills pose the greatest risk to surface water quality. The introduction of large quantities could contaminate drinking water supplies and instream uses for several miles below the spill. But, even in this worst-case situation, surface water contamination would be predominately short-term and acute rather than long-term. This is because the herbicides planned for use by Region 7 are low to moderate in toxicity and relatively short-lived in the environment.

All Federal and State laws and guidelines concerning the maintenance and enhancement of water quality are applicable to DFWP. For example, as legal standards, the Federal Safe Drinking Water Act establishes maximum contaminant levels for potentially toxic substances in drinking water supplies (Table 7). The Environmental Protection Agency's [EPA] Gold Book provides additional protection guidelines for the health and welfare of aquatic life and wildlife (EPA 1986). Revisions to and/or inclusion of new substances in EPA's Gold Book occur periodically.

Other weed treatment methods may affect surface water quality by increasing sediment delivery to water courses. Intensive cultural treatments (e.g. tilling and reseeding) would produce the highest volume of sediment eligible for transport to a surface water course. Despite decreasing vegetative cover of a site, manual methods would not produce nearly as much overland runoff and erosion as tilling because manual methods are usually limited to very small populations whereas cultural methods are usually applied to a much larger land area. Biological methods would not affect surface water quality.

Under Alternative 1 (Status Quo), existing treatment regimes would continue. Surface water impacts would stem from the potential for chemical run-off from treated areas, accidental spills, or aerial drift during application. These risks are discussed above. Additional safeguards proposed under the Plan and embodied in Alternative 2 (INWM) would not be implemented under Alternative 1. Biological control agents already introduced on some properties would not impact surface waters.

Alternative 2 (INWM) attempts to minimize the environmental consequences of herbicide treatments by diversifying weed treatment methods to incorporate non-chemical methods. Where chemicals are applied, all precautions/restrictions proposed in the Plan which apply to shallow groundwater areas will be implemented during treatments near surface waters. For example, herbicide loading, mixing, and storage areas will be located at least 500 feet from open water or shallow groundwater. If mixing and loading of chemicals were to occur on site, open water would not be used for mixing to prevent contamination from back siphoning. Chemicals would not be applied less than 50 feet from any surface water unless a wick applicator is used. Picloram, the most persistent of the herbicides proposed for use, will not be applied on the immediate banks of a water body, below the high water level of a stream, or in identified sensitive groundwater areas. Biological, manual, and cultural methods would not impact surface waters, although cultural methods may temporarily increase sediment delivery to surface waters until vegetation has become established. 
Alternative 3 (Chemical Methods) presents the highest probability of adversely impacting surface waters. The potential impacts would be as described above. Because chemical treatment is the only method proposed in this Alternative, the potential for accidental spills, run-off from treated areas, or aerial drift to contaminate surface waters is heightened.

Alternative 4 (Non-Chemical Methods) presents the least risk to surface waters because chemical treatment methods are not incorporated into this Alternative. There is the potential, however, to increase sediment delivery to surface waters in the short term from cultural treatment methods. Biological, manual, and cultural methods would not impact surface waters, although cultural methods may temporarily increase sediment delivery to surface waters until vegetation has become established.

\section{Site Specific}

Site specific impacts may occur on any property with surface water. Along with FAS's, WMA's and SP's also have perennial streams. In addition, those properties with surface waters used by the public for boating or swimming could be impacted. For example, Tongue River and Hell Creek State Parks are quite popular with the boating public in southeast Montana.

Table 7. Maximum concentrations not to be exceeded in drinking water supplies for herbicides proposed for use by Department of Fish, Wildlife and Parks in Region 3. Information provided by the United States Environmental Protection Agency, Office of Drinking Water, 1990.

$\begin{array}{cccc}\text { Compound } & \text { Status of } & \text { Maximum Contaminant } & \text { Drinking Water } \\ \text { Formulation } & \text { Listing } & \text { Level }(\mu \mathrm{g} / 1)^{2} & \text { Equivalent }\end{array}$

Level $(\mu \mathrm{g} / \mathrm{l})$

clopyralid

2,4-D/amine

glyphosate

picloram

$\begin{array}{lc}- & \text { no data available } \\ \mathbf{P}^{1} & 70 \\ \mathbf{P} & 700 \\ \mathbf{P} & 500\end{array}$

no data available 400

4000

2000

$1 \mathrm{P}=$ proposed for listing

${ }^{2} \mu \mathrm{g} / \mathrm{l} \int$ parts per billion 


\subsection{Fish and Wildlife}

\subsubsection{Current Conditions}

Roughly corresponding with DFWP Region 7 boundaries, the southeast corner of Montana embodies some of the richest and most diverse flora and fauna across Montana. There are over 400 vertebrate species known to occur in latilongs $36,37,38,39,46$, and 47 , where a latilong is a unit of land encompassed by one degree of latitude and one degree of longitude. Appendix B, compiled from several sources as cited, lists the species that have been documented in the latilongs corresponding with Region 7. Six big game species, 71 other mammal species, over 280 bird species, 8 amphibian species, 10 reptile species, and 54 fish species are known to occur in this area (Elser et al. 1980). With some exception, many of these species use Region 7's properties for seasonal or year-round habitation. Waterfowl, upland bird and big game hunting, wildlife viewing, and fishing are primary recreational uses and management focuses of DFWP Region 7.

Table 8 presents a partial list of fish and wildlife species which occur in Region 7.

Table 8. A partial list of fish and wildlife species in southeast Montana.

\begin{tabular}{|c|c|c|c|c|}
\hline Terrestrial & Raptors & Haterfowl & Upland Game Birds & Aquatic \\
\hline $\begin{array}{l}\text { White-tailed deer } \\
\text { Mule deer } \\
\text { Bighorn sheep } \\
\text { Elk } \\
\text { Antelope } \\
\text { Mink } \\
\text { Muskrat } \\
\text { Beaver } \\
\text { Heasel } \\
\text { Coyote } \\
\text { Red fox } \\
\text { Mountain Iion } \\
\text { Bobcat }\end{array}$ & $\begin{array}{l}\text { Bald eagle' } \\
\text { Golden eagle } \\
\text { Peregrine falcon' } \\
\text { Osprey } \\
\text { Swainson's hawk } \\
\text { Red-tailed hawk } \\
\text { Kestrel } \\
\text { Northern harrier } \\
\text { Ferruginous hawk } \\
\text { Rough-legged hawk } \\
\text { Cooper's hawk } \\
\text { Sharp-shinned howk }\end{array}$ & $\begin{array}{l}\text { Canada goose } \\
\text { Mallard } \\
\text { Pintail } \\
\text { Shoveler } \\
\text { Gadwall } \\
\text { Widgeon } \\
\text { Wood duck } \\
\text { Green winged teal } \\
\text { Blue winged teal } \\
\text { Great blue heron' } \\
\text { Sandhill crane } \\
\text { White pelican } \\
\text { Canvasback } \\
\text { Scaup } \\
\text { Rechead }\end{array}$ & $\begin{array}{l}\text { Ring-necked pheasant } \\
\text { Gray partridge } \\
\text { Sage grouse } \\
\text { Sharp-tailed grouse } \\
\text { Turkey }\end{array}$ & $\begin{array}{l}\text { Shovelnose sturgeon } \\
\text { Paddlefish } \\
\text { Rainbow trout } \\
\text { Brown trout } \\
\text { Brook trout } \\
\text { Northern pike } \\
\text { Black bul lhead } \\
\text { Yell low bull head } \\
\text { Chamel catfish } \\
\text { Burbot } \\
\text { Bluegill } \\
\text { Smallmouth bass } \\
\text { Largemouth bass } \\
\text { White crappie } \\
\text { Black crappie } \\
\text { Yellow perch } \\
\text { Sauger } \\
\text { Wa!leye }\end{array}$ \\
\hline
\end{tabular}

1 Species listed under the Federal Endangered Species Act.

2 Species of Special Concern, as identified by the Montana Natural Heritage Program. 


\subsubsection{Analysis of Potential Impacts}

\section{General}

\section{Fish}

Region 7, as part of the Mission of DFWP, is charged with protecting and enhancing fish and wildlife populations and their habitats. Fish populations suffer from the loss or degradation of habitat caused by resource development or other human activities. One threat to fish habitat is the impairment of water quality. Degradation of water quality may directly impact fish populations by preventing the successful completion of a life history stage. Indirect impacts on fishery resources result from negative effects on the aquatic community at lower trophic levels such as vegetation or insects. Furthermore, indirect impacts may result by obstructing the interplay between aquatic and terrestrial environments as they may occur, for example, with loss of the riparian vegetation stabilizing a streambank.

Under Alternative 1, (Status Quo), the existing treatment regimes would remain in place. Chemical treatments would continue at their current locations. Biocontrol agents would persist, as well. This Alternative may impact fishery resources if chemicals are introduced into surface waters. Introduction may result from leaching, accidental spill, aerial drift during application, or as run-off from treated areas after a precipitation event. The discussion of the potential impacts to surface waters summarizes these concerns. However, once herbicides are introduced into surface waters, the toxicity to fish and other aquatic life varies greatly depending upon the species in question, the chemical formulation, and percentage of active ingredient. According to criteria established by the U.S. Fish and Wildlife Service (1980), none of the chemicals proposed for use by DFWP are highly toxic to fish and aquatic life (i.e. having a lethal dose to $50 \%$ of those tested [ $\mathrm{LC}_{50}$ ] less than 1.0 parts per million [ppm], where $\mathrm{LC}_{50}$ is the concentration of toxicant that is fatal to $50 \%$ of the tested organisms over a specified time). Established populations of biocontrol agents are not expected to impact fishery resources.

Under Alternative 2 (Integrated Noxious Weed Management), all methods of noxious weed management may be utilized. The integrated approach will attempt to minimize impacts to fishery resources from chemical treatment activities through implementation of the guidelines contained in the Plan. The Plan further minimizes potential consequences to fish by requiring that only the amine formulation of 2,4-D and the Rodeo formulation of glyphosate be applied near surface waters. Both of these herbicides have been shown to be only slightly toxic to trout (i.e. having $\mathrm{LC}_{50}$ values ranging from 100 to $1000 \mathrm{ppm}$ ). Also, these compounds readily adsorb to soils, which minimizes their mobilization into surface waters, and they do not persist in the environment for long periods. 
Cultural methods which disturb the soil surface (e.g. plowing) may result in short-term increases in sediment delivery to a surface water until the site is revegetated. Increased sediment delivery may impact fish populations because excessive sedimentation is negatively correlated with salmonid spawning success and the survival of fish embryos. Manual and biocontrol treatments methods likely would not increase sediment delivery or affect water quality and would not impact fishery resources.

Alternative 3 (Chemical Methods), in emphasizing chemical treatment methods, has the greatest potential to impact fishery resources. Direct impacts could occur if instream concentrations of herbicides exceeded levels that are toxic to resident fish. Indirect food-chain impacts could occur if in-stream levels become elevated enough to become toxic to aquatic vegetation (particularly algae) or insects.

Because of its reliance on cultural, manual, and biological treatment methods, Alternative 4 (Non-Chemical Methods) has the greatest potential to increase sediment delivery to surface waters. Since manual and biological methods are not as successful at keeping pace with noxious weed seed production, cultural methods would likely comprise a large portion of the treatment activities. Some cultural methods (e.g. plowing) may increase surface runoff to surface waters, leading to increased sediment delivery which could affect spawning success. However, since chemicals would not be used, potential chemical contamination of surface waters would not be possible.

\section{$\underline{\text { Wildlife }}$}

Wildlife populations also suffer from loss or degradation of habitat caused by resource development or other human activities. In the context of noxious weeds, human-influenced disturbance has affected wildlife habitat to the point that noxious weeds are encroaching upon some vegetation communities. Encroaching non-native weed species can alter the balance of structure and species composition in vegetation communities. Most native plant communities provide wildlife with diverse, high quality food and cover resources which could be reduced if vegetation communities become dominated by well-established noxious weeds. However, noxious weed treatment activities may also have some negative consequences to wildlife and wildlife habitat because vegetation is altered or removed. For example, a few wildlife species benefit directly from the presence of noxious weeds. Some birds eat weed seeds and others seek cover in dense weed patches. Small mammals have also been known to use weed seeds as a food source.

Wildlife populations and habitats can be positively and negatively affected by all Alternatives considered in this EA. Each Alternative includes some level of noxious weed treatment. Diminished grass and forb production due to noxious weed encroachment and proliferation may negatively affect habitats for many wildlife species during various seasons of the year. But under all Alternatives, weed treatment activities could disturb wildlife using an area. An indepth discussion of the positive and negative aspects of each Alternative follows. 
Under Alternative 1, (Status Quo), the current noxious weed treatments would continue. Chemical applications would proceed and previously introduced biocontrol agents would persist until they could no longer be sustained by the weed population or died of other causes. Under this Alternative, weeds would likely flourish and expand their distributions. The detrimental effects of noxious weed encroachment into wildlife habitat have already been discussed. Since there would be some degree of chemical treatment activity, wildlife could be directly or indirectly affected by chemicals introduced into the environment as a result of weed management activities.

Chemical applications could affect wildlife directly through the ingestion of treated plants or by dermal absorption if an animal came into contact with treated vegetation. If properly applied, it is unlikely that any species would receive toxic doses of herbicides. However, in cases where animals are directly sprayed or fed exclusively on sprayed vegetation, some could receive toxic doses (BLM 1985). Toxicities of various chemicals considered for use cover a wide range. Tests on domestic animals have shown that the $\mathrm{LD}_{s 0}$ (lethal dose to $50 \%$ of those tested) for 2,4-D is the lowest (most toxic) of pesticides considered in this assessment (Tables 9 and 10). For cattle (or for comparison, elk) grazing immediately after spraying 2,4-D at prescribed rates and only on sprayed vegetation, ingestion of the chemical would only be about $20 \%$ of the $\mathrm{LD}_{s 0}$ (Lolo National Forest 1989). For dogs (or for comparison, coyotes), ingestion of a large quantity of meat from an animal that has eaten heavily on sprayed vegetation would result in less than $1 / 400$ of the $\mathrm{LD}_{50}$. It is difficult to extrapolate the level of effects on domestic animals to wildlife. Nonetheless, based on this data, it appears that neither deer nor coyotes could ingest enough of any pesticide through normal eating behavior to be fatal.

Table 9. Median lethal dose $\left(L D_{50}\right)$ for domestic animals expressed in milligrams per kilogram for 3 herbicides proposed for use on Department of Fish, Wildlife and Park properties in Region 7.

\begin{tabular}{lrll}
\hline Species & Picloram & $2,4-\mathrm{D}$ & Glyphosate \\
\hline Mouse & $2,000-4,000$ & 368 & -2 \\
(Rat) & 8,200 & 375 & 4,320 \\
Dog & - & 100 & - \\
Cat & - & 820 & - \\
Chicken & 6,000 & 541 & 15,000 no effect \\
(mallard) & $>2,000$ & - & $>2,000$ \\
Pigeon & - & 668 & - \\
Rabbit & 2,000 & 424 & 3,800 \\
Cow & 540 & 100 & - \\
(Mule deer) & - & $400-800$ & - \\
\hline
\end{tabular}

1 The data in this table were taken from Lolo National Forest (1989); Sassman et al. (1984); USDA (1988). The reader should consult those documents for thorough discussions of herbicide toxicity.

2

Data not available 
Monnig (1988) demonstrated that warm-blooded animals, when fed high concentrations of 2,4-D, picloram, and glyphosate, excrete the chemicals rapidly and do not retain pesticides in internal organs. Analysis performed for the final EIS on eradication of cannabis on federal lands showed that most large animals cannot receive lethal doses of herbicides (2,4-D or glyphosate) and that it is very unlikely, in even the most extreme dose cases, that small animals (such as mice or toads) would die (Table 10) (BLM 1985). This table demonstrates that in a worst-case situation, no listed animal would receive a dose greater than $11 \%$ of its median lethal dose for 2,4-D or $1 \%$ for glyphosate (BLM 1985). Thus, it seems that most wildlife species are not likely to be affected directly by ingestion of herbicides or herbicide-treated vegetation. However, none of these studies considered the possible impacts of chemical treatment in areas used for fawning, nesting, or rearing of young. It is possible that young animals could be negatively affected through direct contact with or ingestion of herbicide. To date, no evidence exists to support this speculation.

Bio-accumulation of contaminants in the food chain was of critical importance with the now-banned insecticides DDT and DDE, particularly for sensitive species such as raptors. It has been shown that herbicides proposed for use under the Plan are metabolized readily and excreted by mammals. Glyphosate, 2,4-D, and picloram do not bio-accumulate in fish and mammals (EPA 1983, 1986, 1988; USDA 1984). No evidence was found in the literature to support bio-accumulation problems from clopyralid.

Indirectly, chemical applications, may negatively affect wildlife over the short-term by killing native broadleaf plant species which are important sources of seasonal food and/or cover. Depending on the rate of application, the size of the area treated and the techniques used to apply herbicides, there can be losses of non-target vegetation important to wildlife species (BLM 1985). While woody species, such as sagebrush and willows, are highly valued for their uses by wildlife, they can be acutely affected by herbicides and the negative effects are long-term. Currently, established biocontrol agents are not expected to impact wildlife resources, either directly or indirectly.

Alternative 2 (INWM) combines manual, cultural, biological, and chemical treatment methods. By using an integrated approach to weed management, areas critical to wildlife populations during specific seasons could be treated at times or by techniques that would have the fewest negative impacts. Careful application of herbicides in sensitive areas, in conjunction with biological, manual, or cultural techniques, offers the best solutions for preserving the native vegetation component of wildlife habitat and the integrity of wildlife resources. In situations where woody species are important to wildlife management goals (e.g. WMA's), non-chemical methods will be emphasized such as lifting, pulling, walking over rough terrain, and operating equipment that may result in extremity injuries. These risks would be kept to a minimum if Occupational Safety and Health Administration work practices and standards are followed. 
Table 10.

Routine and extreme dose levels of 2,4-D and glyphosate compared to the median lethal dose $\left(L_{50}\right)$ for various animal species. Table is adapted from the Bureau of Land Management Northwest Area Noxious Weed Control Program Final Environmental Impact Statement, 1985.

\begin{tabular}{lccll} 
Species & $\begin{array}{l}\text { Routine } \\
\text { Case Dose }\end{array}$ & $\begin{array}{l}\text { Extreme } \\
\text { Case Dose }\end{array}$ & $\begin{array}{l}\text { Median Lethal } \\
\text { Dose LD } \text { L1 }^{1}\end{array}$ & Lab Animal \\
\hline \multicolumn{5}{c}{ 2,4-D } \\
Flicker & 13.700 & 123.33 & $472(\mathrm{~T})$ & \\
Dove & 8.710 & 41.35 & $472(\mathrm{~T})$ & $\begin{array}{l}\text { Pheasants } \\
\text { Jay }\end{array}$ \\
Kingfisher & 12.850 & 97.95 & $472(\mathrm{~T})$ & Pheasants \\
Owl & 0.017 & 0.42 & $472(\mathrm{~T})$ & $\begin{array}{l}\text { Pheasants } \\
\text { Mouse }\end{array}$ \\
Rabbit & 7.930 & 23.63 & $472(\mathrm{~T})$ & Pheasants \\
Deer & 39.640 & 197.90 & $380(\mathrm{BE})$ & Mouse \\
Fox & 5.520 & 44.70 & $424(\mathrm{BE})$ & Rabbit \\
Toad & 1.140 & 13.76 & $400(\mathrm{~A})$ & Mule Deer \\
Snake & 2.020 & 9.27 & $100(\mathrm{~A})$ & Dog \\
Eggs & 18.040 & 139.90 & $200(\mathrm{M})$ & tadpole \\
& 19.820 & 59.10 & $200(\mathrm{M})$ & Toad \\
& 9.420 & 47.10 & No adverse effects & Hen eggs \\
\hline
\end{tabular}

\section{Glyphosate}

\begin{tabular}{lrrcl} 
Flicker & 7.2100 & 64.90 & 4,640 & Quail \\
Dove & 4.5900 & 21.78 & 4,640 & Quail \\
Jay & 6.7600 & 51.51 & 4,640 & Quail \\
Kingfisher & 0.0087 & 0.22 & 4,640 & Quail \\
Screech Owl & 4.1700 & 12.44 & 4,640 & Quail \\
Mouse & 20.8600 & 104.20 & 4,000 & Rat \\
Rabbit & 2.9100 & 23.53 & 3,800 & Rabbit \\
Deer & 0.6000 & 7.22 & 3,800 & Rabbit \\
Fox & 1.0600 & 4.88 & 3,800 & Rabbit \\
Toad & 9.4900 & 73.65 & -2 & \\
Snake & 10.4300 & 31.10 & - & \\
Bird Eggs & 4.9600 & 24.78 & - & \\
\hline
\end{tabular}

${ }^{1}$ Dose (mg/kg) lethal to $50 \%$ of those tested; BE = Butyl Ester, $\mathrm{A}=$ Acid, $\mathrm{T}=$ Technical, and $\mathrm{M}=$ Amine

2 No data available. 
This approach integrates treatment techniques with natural resource values and assures that the proper technique will be used in sensitive areas to minimize impacts to other resources, including wildlife. The Plan's management objective for wildlife is to "protect existing, diverse wildlife habitats from encroachment by weeds, while ensuring that threatened, endangered, rare, or unique species are not adversely affected by weed treatments". The Plan lists several management guidelines which describe the inherent mitigative aspects. These address specific and general approaches to treating sensitive areas that will be determined and delineated for each project regardless of the treatment method.

Direct impacts to wildlife under Alternative 2, resulting from chemical applications, are the same as those described for Alternative 1. Indirect impacts to wildlife, resulting from chemical applications, would also be similar to those described above. Other indirect impacts may result from temporary displacement because important seasonal vegetation may be disturbed during non-chemical treatments, such as mowing.

The establishment of biocontrol agents is not expected to affect wildlife, either directly or indirectly.

Alternative 3 (Chemical Methods), emphasizes chemical methods in any situation requiring noxious weed treatment. Direct and indirect impacts resulting from this Alternative are similar to those discussed for Alternative 1. Furthermore, Alternative 3 poses the greatest risk to wildlife resources because the risks of over-application, chemical spills, and drift during application.

Under Alternative 4 (Non-Chemical Methods), non-chemical methods would be the only means of arresting the encroachment of noxious weeds into desirable vegetation communities. Vigorous application of manual and cultural methods under this Alternative, may temporarily delay the establishment of noxious weeds in weed-free areas, but would probably not effectively reduce weeds in vital habitats presently containing weeds. Direct impacts to wildlife of non-chemical methods include the short-term displacement of animals during treatment activities. Indirect impacts may result because non-target, native species may be impacted during treatment. Noxious weeds may encroach upon scarified, cultivated, or other disturbed soils if revegetation of native species is not rapid. The use of grazing livestock, such as sheep, to reduce and contain weeds; in addition to possibly displacing wildlife, may negatively affect non-target vegetation. If Alternative 4 (Non-Chemical Methods) is selected, weeds will likely expand and continue to encroach upon desirable plant communities.

\section{Site Specific}

\section{Fish}

Many properties in Region 7 (FAS's in particular) incorporate surface waters which sustain aquatic communities, including sport fisheries. These sites could be adversely affected by 
inappropriately or improperly applied herbicides. If precautions and mitigation measures outlined in the Plan and incorporated into Alternative 2 are followed, the risk of negatively affecting the fishery resources is slight.

Species of Special Concern: As discussed previously, potential impacts to fishery resources exist, but can be mitigated under Alternative 2. Currently, only the Pallid sturgeon occurring in Region 7 is listed under the Endangered Species Act. Although not petitioned for listing, the Northern redbelly dace, Sturgeon chub, Sicklefin chub and Blue sucker are considered Montana Species of Special Concern. In addition, four other species are considered rare in this region, Mountain whitefish, Rainbow smelt, mosquitofish, and White bass. Therefore, chemical treatment activities should be considered carefully on FAS's, WMA's and SP's in the Yellowstone, Tongue, Powder and Missouri River drainages. In such cases, all additional safeguards described in the Plan should be followed.

\section{Wildlife}

Direct negative effects to wildlife resources are likely to be minimal, as discussed previously. Short-term, potential indirect effects of herbicide applications on wildlife vegetative food sources do exist, especially for broadleaf forbs and woody shrubs. If chemical treatments are not carefully conducted, important vegetative species could be affected. This could be particularly true on the WMA's which typically harbor ungulates during winter, the most stressful season for wildlife. Emergent, floating, and submergent vegetation important to waterfowl and other species could also be negatively affected by improperly applied chemicals. If the additional safeguards outlined in the Plan (Alternative 2) are followed, the risk of negatively affecting wildlife resources is minimal.

Species of Special Concern: As discussed previously, potential toxic effects from herbicides is minimal for wildlife species in general. However, federally-designated, threatened or endangered species require special consideration. Although not recognized under the Endangered Species Act, Species of Special Concern also require consideration. For example, the primary concern for Bald eagles is disturbance during nest building and incubation (March through June). The proximity of nests to R-7 WMA's, SP's and FAS's makes implementation of weed management actions of some concern. Weed treatments would usually occur late May through September. The level of disturbance should be no greater than that expected from typical recreationist use at these sites. Mitigation measures include guidelines recommended by the Montana Bald Eagle Working Group (1991). 


\subsection{Vegetation}

\subsubsection{Current Conditions}

The geology and topography of southeastern Montana yields a diverse pattern of vegetation, including plains grassland, plains forest, and riparian. Vegetation resources on DFWP Region 7 lands include rangelands, wetlands, riparian areas, and forested areas. Upland shrub and grassland communities include sagebrush, greasewood, rabbitbrush, and short and mid grasses including Blue grama, buffalograss, Western wheatgrass and Prairie sandreed. Forbs occur in smaller amounts, including Fringed sagewort, Prickly pear, American vetch and yucca. Lowland tall grass areas include Green needlegrass, Smooth brome, Canada wildrye, and needle-and-thread. Ponderosa pine and Rocky Mountain juniper are the most common tree species on dry forest sites. Riparian communities often include overstory vegetation of cottonwood, Green ash, Russian olive and chokecherry. Tall shrub species include willows, Buffalo berry, Red dogwood and short shrubs include snowberry and Wild rose. Wetland marsh vegetation consists primarily of cattails, rushes and sedges.

During a survey of most Region 7 properties during the summer, 1991, noxious weeds were documented on all but a few properties, though with considerable variation in abundance. Canada thistle and Leafy spurge were the most common noxious weed species encountered. Other "noxious" weed species declared by individual counties were also documented on DFWP properties. The most common were Common burdock, Salt cedar, and Black henbane. Noxious weeds are strong competitors for moisture and soil nutrients. The possible effects of a decline in native vegetation resources on wildlife has already been discussed previously.

\section{Plant Species of Special Concern}

The Natural Heritage Program system, a partnership between The Nature Conservancy and state governments, was established in part as a clearinghouse to aid states in identifying and studying rare species. Rare plant species are protected under the Federal Endangered Species Act of 1973 (PL 93-205 as amended and rules 50 CFR Part 402). At this time, there are no threatened or endangered plant species on Region 7 properties. However, according to the Montana Natural Heritage Program, a number of plant species listed as Species of Special Concern (because of limited distribution or small populations) occur on Region 7 properties. Table 11 summarizes these. 

properties in Region 3, as identified by the Montana Natural Heritage Program, 1993.

Common Name
Narrow leaf milkweed
Smooth goosefoot
Schweinitzii flatsedge
Silky prairie clover
Moss phlox
Narrowleaf penstemon
Sand bluestem/
needle-and-thread
community type

\section{Scientific Name}

Asclepias stenophylla

Chenopodium subglabrum

Cyperus schweinitzii

Dalea villosa

Pholx andicola

Penstemon angustifolius

Andropogon hallii/

Stipa comata

Artemisia cana)

Carex helophila

Silver sagebrush/

community type

Blue toadflax
Limaria canadensis var texana
Status $^{1}$

G4, S1

G4, S1

G5, S1

G5, S1

G4, S1

G5, S1

G3, S3

G3, S3

G4, S1

Makoshika SP

G4, S3

Makoshika SP

Rocky Mountain juniper/ Juniperus scopulonum Little-seed ricegrass Oryzopsis micrantha habitat type

1 Global ranks:

G2 imperiled; 6-20 occurrences

G3 threatened throughout range

G4 apparently secure

G5 demonstrably secure
State ranks:

S1 critically imperiled in Montana; $\leq 5$ occurrences

S2 critically imperiled in Montana; 6-20 occurrences

S3 rare in Montana; $\geq 21$ occurrences

S4 apparently secure

2 Ranking not applicable.

3 This species is being taxonomically redefined as part of a species which extends from Alaska to the southwest. The Montana Natural Heritage Program recommends that this taxa no longer be considered for listing under the Endangered Species Act. 


\subsubsection{Analysis of Potential Impacts}

\section{General}

The nature and extent of impacts on vegetation resources as a result of noxious weed management would vary under each Alternative, as described below.

Under Alternative 1 (Status Quo), noxious weeds would be treated, but only at the current intensity levels. Thus, it is likely that noxious weeds would continue to spread and that new species would likely establish on DFWP properties. Because treatment activities would be limited, it is also likely that noxious weeds would spread within Region properties and beyond property boundaries. Under current direction, chemical treatments would continue. Chemical treatments may affect non-target vegetation. This could result from the use of non-selective herbicides, broad-scale application methods, or over application. Impact severity would depend on the environmental conditions during application, application rate, method, carrier, and the herbicide. Herbicides which are selective for broadleaf weed species (such as 2,4-D and picloram) also kill native forbs, shrubs, and trees, thereby potentially decreasing natural diversity. Grasses are tolerant of most broadleaf herbicides and would benefit from treatment. Non-selective herbicides (glyphosate) can kill all vegetation, which creates a setting conducive for the re-establishment of weeds. Established biocontrol agents generally do not affect non-target vegetation resources because the agents are host-specific to a particular noxious weed species (Littlefield 1993). However, there was one reported incidence of an insect affecting a non-target species. Introduced to Musk thistle, the Seed weevil Rhinocyllus conicus also plagued a rare, native thistle called Longstyled thistle (Cirsium longistylum) (Achuss and Schassberger 1991). The likelihood of a similar outcome in the future is reduced because now screening tests are more rigorous and include taxonomically related and morphologically similar native species (Littlefield 1993).

Alternative 2 (INWM), is expected to have the least impact on vegetation resources. This Alternative specifies the implementation of the Plan which allows for flexibility in approach and the use of optimum treatment methods for specific sites. Chemical treatments would still be used; however, the Plan outlines precautions and use standards that are designed to minimize or eliminate the potential adverse effects of herbicides on desirable vegetation. Special attention is given to riparian and wetland areas. If these guidelines are followed then impacts would be low. Manual methods, used in localized situations where weed populations are small, would not adversely impact desirable vegetation. Cultural treatments, such as mowing, can be a short-term solution to prevent seed production. Short-term effects on desirable vegetation could occur. Tilling would be considered only for areas that had previously been cultivated because soil disturbance increases the likelihood of weed encroachment. 
Use of grazing animals to treat weeds would have little impact on desirable vegetation as long as herds are confined and use is carefully monitored since livestock will feed both on weeds and desirable vegetation. Indirectly, compaction of a site could slow the recovery of desirable plants. Because biological control organisms are host specific, no adverse impacts to desirable vegetation are expected. This Alternative is the best solution for the long-term management of noxious weeds and preservation of vegetation resources through implementation of the Plan.

Alternative 3 (Chemical Methods) is expected to have the greatest impact on vegetation resources. Since chemical treatments would be the sole method, non-target vegetation would be adversely impacted, particularly woody species. The type and severity of such impacts are discussed under Alternative 1. Although this Alternative would effectively reduce noxious weeds, the magnitude of impacts to non-target, desirable vegetation could be unacceptable.

Under Alternative 4 (Non-Chemical Methods), the emphasis would be on manual, cultural, and biological control methods. These methods would likely have some adverse impacts on non-target vegetation, as discussed for Alternative 2 (INWM). This Alternative would not lead to long-term success at managing noxious weeds. Rather, noxious weeds would likely proliferate.

\section{Plant Species of Special Concern}

Species of Special Concern are declared as such because their numbers are greatly reduced, their habitat is declining or threatened, or because populations occur in a limited or noncontiguous distribution. Studies addressing how noxious weeds affect species of concern are few. Lessica and Shelly (1991) showed reductions in reproductive output of Sapphire rockcress (Arabis fecunda) where Spotted knapweed had invaded. Currently, the rates of spread of Canada thistle and Leafy spurge appear to be the highest of the noxious weeds encountered on DFWP Region 7 properties. It is known that noxious weeds are very competitive and could crowd out Species of Special Concern. For those rare species whose habitat coincides with areas susceptible to noxious weed encroachment, the threat may be very high. For example, Medicine Rocks SP contains five Species of Special Concern all rare throughout their ranges. In an effort to protect rare plants and plant community types the Montana Natural Heritage Program indicates that the site should be evaluated for weed invasion.

Rare plants typically occur in very small populations and usually in non-contiguous distributions. Use of herbicides could cause a significant loss by eliminating population(s) or reducing numbers within a population. Cultural methods could cause uprooting or physical damage, loss of seed production, or outright destruction. Identification of rare plant populations during treatment area planning would prevent losses. Identification of such populations is only incorporated into Alternative 2, through the Plan. None of the other Alternatives include any provisions for Species of Special Concern. 
All Region 7 properties have desirable vegetation communities that could be impacted by improper herbicide treatments, whether it be in a natural field setting such a WMA or a landscaped setting such as the regional headquarters complex. Spot spraying and the use of appropriate herbicide formulations would reduce the potential for short-term injury or long-term plant community alteration. In the case of Species of Special Concern, impacts resulting from weed management actions could be acute in the absence of knowledge of these rare plants. Site specific impacts to populations of plant species of Special Concern could occur on any of the DFWP properties supporting rare plants. Those plant species and the DFWP properties on which they occur are listed in Table 11. All the plant species of Special Concern listed in Table 11 could be affected by chemical treatments because these species are either broad-leaved or woody, characteristics which most herbicides are not selective against. Additional safeguards outlined in the Plan would decrease the risk of negatively affecting these rare plants.

\subsection{Recreation}

\subsubsection{Current Conditions}

Southeast Montana draws much national and some international attention for its natural resources and outdoor recreation opportunities. DFWP properties in Region 7 are part of that attraction. These lands offer a wide variety of experiences such as waterfowl, upland game bird and big game hunting, year-round fishing, camping, picnicking, swimming, sailboarding, motorboating, canoeing, waterskiing, and wildlife viewing and photography. Other sites provide opportunities to experience historical settings (e.g. Rosebud Battlefield and Medicine Rocks SP's) or unique geological features (e.g. Makoshika and Medicine Rocks SP's). In addition, DFWP properties offer a wide variety of landscapes in which to recreate, ranging from river bottoms at FAS's, Yellowstone River bottoms or islands on a WMA, or the site of an historical event. Healthy, native plant communities are a significant part of the recreational experience, from both ecological and aesthetic perspectives.

The most heavily used roads, trails, campsites, and picnic areas have problems associated with soil compaction, braiding of trails, and noxious weeds resulting from disturbance. As indicated previously, noxious weeds occur on most DFWP properties in Region 7. Some recreationists find that noxious weeds detract from their enjoyment of an outdoor experience or particular site, while others don't seem to mind. Yet other recreationists are unaware of noxious weeds, how they are spread, and the repercussions of unchecked weed proliferation upon natural and recreational resources. Thus, the impact of noxious weeds upon recreationists will depend on the perspective of the recreationist. However, most recreationists would likely be indirectly affected if weeds were allowed to spread unchecked. This is because of the concurrent changes in desirable vegetation communities. 


\subsubsection{Analysis of Potential Impacts}

\section{$\underline{\text { General }}$}

The impacts of noxious weed treatment upon recreation vary with the type of treatment and the type of recreation. Generally, recreation on DFWP properties is oriented towards foot or horse travel as vehicles are restricted to established roads, trails, and parking areas. None of the Alternatives are expected to affect vehicular access or the driving of any motorized vehicle where they are permitted. However, while travelling on foot (or horse back) and pursuing any of the recreational activities listed above, recreationists may be impacted by the Alternatives, as described below.

Alternative 1 (Status Quo) would likely have a long-term negative impact on recreation resources. Under this Alternative, weed treatments would continue, but weeds would likely proliferate. Therefore, it has the potential to greatly affect recreation in the long run through changes to vegetation communities and, potentially, wildlife resources. Treatment of weeds, as currently practiced, would involve chemical applications and the established biocontrol agent releases. Of the two methods, chemical treatments would affect recreationists in the short-term, whereas biocontrol agents would not. In some situations, chemical applications may preclude public use for a period of time during and after the application. Similarly, some recreationists may find chemical odors unpleasant and offensive. Recreationists may be visually or aesthetically impacted since herbicides can affect non-target vegetation.

Alternative 2 (INWM) would have the fewest long-term, negative impacts to recreation. Under this Alternative, the Plan would be implemented which combines a wide variety of weed treatments with site-specific planning with public awareness of the problems associated with noxious weeds. Although DFWP's mission does not include weed education, the agency may cooperate with public awareness programs initiated by other organizations. Such initiatives would help recreationists identify problem areas, understand where the most sensitive areas exist, and give them the opportunity to be involved in weed management. DFWP involvement may include a display at Regional Headquarters Offices or the distribution of a noxious weed information sheet or brochure through the vehicle, boat, and trailer registration system or through hunting and fishing license dealers. Other involvement may include range tours of the WMA's. This Alternative presents the best opportunity for the long-term management of noxious weeds.

The Plan involves the use of chemical, biological, cultural, and manual methods of noxious weed treatment. The impacts of chemical treatments would be similar to those described above, but with the following exceptions. In contrast with Alternative 1, the Plan includes safeguards and guidelines for application which would protect other resource values such as recreation. These guidelines are intended to minimize short-term impacts on recreational resources and public use of DFWP properties. Biological, manual, and cultural methods would not affect recreation. 
Alternative 3 (Chemical Methods) would have the greatest negative impacts to recreation. By emphasizing herbicide treatments, this Alternative could cause the frequent closure of sites to public use during application, long-term adverse effects on non-target vegetation, and increased risk of exposure to chemicals by the public. Similar impacts as those described under Alternative 1 could be expected under this Alternative. Some degree of weed encroachment would still occur if treatments were not applied correctly or frequently enough.

Alternative 4 (Non-Chemical Methods) prescribes the use of biological, manual, and cultural methods to reduce noxious weed populations. These methods can be effective in certain situations. However, as indicated previously in the discussion of vegetation, cultural methods may actually lead to an increase in noxious weeds if not conducted properly. Manual methods are time-consuming. Biocontrol methods require longer time intervals for successful management of weeds. For these reasons, this Alternative may not treat noxious weeds as effectively or efficiently as other Alternatives. Thus, over the long-term, recreation may be impacted through the alteration of desirable vegetation communities. In the shortterm, however, this Alternative would have the least impact on recreation. Area closures required during chemical applications would not be necessary under this Alternative. Furthermore, biological, manual, and cultural methods would not affect recreational access or pursuits.

\section{Site Specific}

Site-specific impacts could be anticipated under those Alternatives which include some degree of chemical treatments and on those sites which sustain the greatest public use. Some of the most visited properties in Region 7 include Makoshika SP, Tongue River SP and FAS's near population centers. Of the three Alternatives which include some provision for chemical treatments $(1,2$, and 3$)$, the site-specific impacts would be greatest under Alternative 1 (Status Quo) because no safeguards for non-target vegetation or other resources would be implemented. Alternative 3 (Chemical Methods) would also result in site-specific impacts at high visitation sites because herbicides would be the only method of treatment, leading to increased frequency of application. Likewise, safeguards would not be implemented under this Alternative either. Alternative 2 (INWM) would have the least impact on highly visited sites because safeguards would be implemented and because chemical treatments would be just one of the possible treatment methods.

\subsection{Human Health}

\subsubsection{Current Conditions}

Montana is recognized nationally for its clean, healthy environment. Implicit in a healthy environment is clean air and water, securing healthy living conditions for humans. As noted previously, Montana's air and water quality are generally good, with isolated exceptions. 


\subsubsection{Analysis of Potential Impacts}

\section{$\underline{\text { General }}$}

General impacts to human health could be anticipated if air and water quality are degraded for any reason. Of all the noxious weed treatment methods under consideration, chemical methods pose the highest risk to air and water quality. Earlier sections of this document specified potential impacts of noxious weed management activities on air and water resources in general and more specifically from chemical methods. The following discussion reviews these impacts from the perspective of human health. Those impacts would be most pronounced on sites requiring the most intense noxious weed treatments and on those sites where use by the public is high.

Alternative 1 (Status Quo) describes the continuation of current noxious weed treatment methods and intensities: chemical applications without safeguards beyond manufacturer's labels and established biocontrol agents. Human health could be affected by herbicide use under this Alternative. Detailed discussions on this subject can be found in the following publications: Lolo National Forest Noxious Weed Management Draft EIS (1989); Human Health Risk Assessment of Herbicide Applications to Control Noxious Weeds and Poisonous Plants in the Northern Region of USDA Forest Service (Monnig 1988); Northwest Area Noxious Weed Control Program EIS, Final and Supplement (BLM 1985, 1987). We rely on these analyses and highlight several concepts: exposure routes, bioaccumulation, carcinogenic properties, and chemical additives.

The Northern Region assessment (Monnig 1988) is a "worst-case analysis" using several conservative assumptions that purposely over-estimate the likelihood and severity of exposure, accidents, and the resulting effects. Those assumptions include: higher application rates than label recommendations, continuous application over an entire project area, mixing and application errors that would not generally occur, human residences and food sources much closer than would occur in most projects, skin exposure estimates for workers failing to wear recommended protective clothing, and that there is no threshold or safe level for exposure to carcinogens (cancer-causing agents).

Human exposure routes are related to either direct contact with herbicides through spray drift, spills, and sprayed vegetation or to indirect contact through consumption of contaminated water, vegetables, fish, or grazing animals. The exposure risk is greatest for those workers who apply herbicides without the appropriate protective equipment such as clothing, respirators, and eye protection.

Unlike DDT, it appears that bio-accumulation does not occur with picloram, 2,4-D, and glyphosate. These herbicides are water soluble and are excreted rapidly. A small percentage of the population is hypersensitive to one or more of these chemicals and can suffer severe and long lasting symptoms after small doses. Workers are at the highest risk. Using proper application techniques and wearing recommended protective clothing can 
reduce this risk. Additional precautions would be implemented when herbicides are applied to high human use areas such as work places, campgrounds, and parks. Formulations of glyphosate and 2,4-D registered for use in human occupation areas would be used.

Of the chemicals proposed for use in Region 7, 2,4-D presents the highest cancer risk based on animal feeding studies. However, this risk is considered to be very low. Again, chemical applicators would be at the highest risk. The Lolo National Forest EIS (1989) states that "although human carcinogenic risk levels for these herbicides appear to be quite low, scientific uncertainty still exists regarding the exact level of these risks." DFWP employees are required to wear the appropriate protective equipment during applications to minimize their exposure. Many chemical applications have been contracted out to county weed control applicators in the past. The number of contracts would likely increase in the future under Alternatives 1,2, and 3. This would minimize exposure to DFWP employees, but county applicators will then be increasing their exposure. However, county applicators usually have the ability to apply chemicals more safely because of their significant investment in safety equipment and clothing.

2,4-D is a chlorophenol-type herbicide in the dioxin family of chemicals. The isomers of dioxin vary in their toxicity but the "highly toxic dioxin" isomer found in 2,4,5-T is not found in 2,4-D (Linnainmaa 1983). The Canadian government appears to have avoided this issue by requiring that 2,4-D formulations have less that 10 parts per billion of any dioxin isomer. This has effectively left only the amine formulation of 2,4-D on the Canadian market (Tosine 1983).

Inert ingredients in herbicide formulations include surfactant, emulsifiers, diluents, and other additives. These have come under scrutiny for possible toxicological and carcinogenic effects. This concept has not been extensively researched. As of 1990, the EPA had listed about 115 inert substances which require further regulation or testing. Acute toxic effects of the POEA family of chemicals, a surfactant used in the Roundup formulation of glyphosate, have been debated (O'Brien 1990). Furthermore, synergism, the possible interaction of herbicide ingredients with other chemicals in the environment (pollutants and other herbicides), has not been well studied.

This discussion points out the need for caution in the use of all herbicides, especially 2,4-D. However, this Alternative does not include any provisions for safeguarding other resources beyond that specified on chemical label instructions.

Established biocontrol agent populations would not impact human health. However, biocontrol agents are not expected to keep pace with the rate of spread of many noxious weed species and weed populations would likely expand. The spread and increase of noxious weeds populations may increase pollen levels and subsequently exacerbate human allergies. 
Alternative 2 (INWM) also incorporates chemical methods, but such applications would be conducted with safeguards and consideration for other resource values. Such considerations would help diminish concern over exposure routes, bio-accumulation, carcinogenic properties, and chemical additives. Furthermore, chemical treatments would only be used in situations where other methods (biological, cultural, or manual) are not feasible. These non-chemical methods are not expected to have significant impacts on human health. Cultural methods may temporarily increase dust or pollen levels in the air, aggravating allergies. Manual and cultural methods pose some risk to workers. These risks include injuries typical of occupations requiring moderate to heavy physical labor such as lifting, pulling, walking over rough terrain, and operating equipment that may result in extremity injuries. These risks would be kept to a minimum if occupational safety and health administration work practices and standards are followed.

Under Alternative 3 (Chemical Methods), chemical applications would be the only means of treating noxious weeds. As such, this Alternative presents similar risks to human health as those discussed under Alternative 1. However, Alternative 3 poses the highest risk to human health because of the increased exposure to chemicals for both the public and chemical applicators as a result of the increased frequency of application and increased volume of chemicals introduced into the environment.

Alternative 4 (Non-Chemical) poses the lowest risk to human health because the most risky method of weed treatment (chemical) is not incorporated. The impacts of non-chemical treatment methods are highlighted in the discussion of Alternative 2. Human allergies may be exacerbated by dust from cultural methods or from elevated pollen levels as nonchemical methods may not keep noxious weeds in check as effectively as other Alternatives.

\section{Site Specific}

Site specific impacts to human health would be expected at those sites heavily visited by the public, where public use is concentrated, such as in campgrounds and where the intensity of noxious weed treatments is most pronounced. High public use is noted at the following sites: Makoshika SP, Tongue River SP, and a few FAS's near population centers. Moreover, public use at these sites is often concentrated near campgrounds, picnic facilities, restrooms, and boat ramps in the case of FAS's. Those DFWP properties with established noxious weed populations require the most intense treatments. Therefore, the potential impacts of exposure to chemicals for the public, as well as for DFWP employees, is elevated. These properties are: Makoshika SP, West Rosebud, Kinsey Bridge, and 12 Mile Dam FAS. 


\subsection{Cultural and Historic Resources}

\subsubsection{Current Conditions}

Cultural resources are important to this and future generations. Cultural resources under the care of DFWP are typically associated with, but not exclusive to, the State Parks system. In Region 7, such cultural resources are preserved at a number of sites including Rosebud Battlefield SP, the site of the 1876 battle between the US Army under Gen. George Crook and the Cheyenne and Sioux under Two Moons and Crazy Horse. Medicine Rocks SP is purported to have significant Native American cultural resources, in addition to it's historical significance as an eastern Montana landmark. It has been surmised that William Clark (Lewis \& Clark) camped on or near one of the small islands contained within Pirogue Island SP. Most of these sites have noxious weeds growing within DFWP property boundaries. Other miscellaneous "weedy" species which are not designated as "noxious" do occur. The presence of noxious weeds may not directly threaten or harm a cultural or historic resource. However, their presence may affect a site's integrity and a visitor's perception or interpretation of the site.

\subsubsection{Analysis of Potential Impacts}

\section{General}

As described previously under recreation, the presence of noxious weeds may impair one's enjoyment of a site from an aesthetic point of view. In the case of cultural and/or historic sites, the impairment may be more serious. Where noxious weeds occur in a setting where cultural/historic resources are preserved, the treatment of noxious weeds may adversely affect the resource depending on the method employed. In general, cultural methods involving hard-edged tools or implements would have a greater potential for impact than the other methods. Tilling, reseeding, or mowing activities could damage or destroy surface and/or subsurface artifacts. As each cultural/historic resource within the State Parks system is unique, the impacts of the various noxious weed management Alternatives are discussed on a site-specific basis.

\section{Site Specific}

Alternative 1 (Status Quo) is the continuation of previous noxious weed treatment efforts by chemical or biological means. This Alternative would not incorporate safeguards for other resource values. As such, cultural and historical resources may be impacted by a lack of consideration for their value during the planning stages of noxious weed treatment. Also, under this Alternative, newly-established noxious weeds would likely proliferate. Increases in noxious weeds would negatively affect the cultural and/or historic interpretation of a site. Chemical treatments could impact non-target vegetation. This would be especially detrimental at sites where the vegetation component contributes to the interpretation of the site, as is the case at Rosebud Battlefield, Pirogue Island and Medicine Rocks state parks. Cultural/historic sites in Region 7 would not be impacted by established biocontrol agents. 
Alternative 2 (INWM) blends site treatment needs with resource values and appropriate methods to achieve noxious weed reduction. Possible methods include chemical, biological, manual, and cultural. This is the only Alternative which truly considers the importance of cultural/historic resources and attempts to achieve management objectives without impairing those values. Chemical treatments could impact non-target vegetation. This would be especially detrimental at sites where the vegetation component contributes to the interpretation of the site, such as Rosebud Battlefield, Pirogue Island and Medicine Rocks state parks. However, such impacts would be minimized by implementation of the guidelines outlined in the Plan. Cultural/historic sites would not be impacted by the establishment of biocontrol agents or by manual treatment methods. Cultural methods may have significant impacts if not properly planned or carried out. For example, possible battle and soldier's grave sites at Rosebud Battlefield could be disrupted by mowing or tilling activities, but in requiring consideration of all site values, the Plan would minimize the possibility of disruption.

Alternative 3 (Chemical Methods) emphasizes the use of chemicals without consideration of site values and resources. Impacts of chemical treatments under this Alternative would be similar to those described for Alternative 1, only the greater reliance on chemicals would put non-target vegetation resources at even greater risk. Again, Rosebud Battlefield, Pirogue Island and Medicine Rocks state parks could suffer the most serious impacts.

Alternative 4 (Non-Chemical Methods) only permits the use of non-chemical treatments. Cultural/historic sites would not be impacted by the establishment of biocontrol agents or by manual treatment methods. Cultural methods may have significant impacts if not properly planned or carried out. For example, possible battle and soldier's grave sites at Rosebud Battlefield could be disrupted by mowing or tilling activities. 


\section{3* Environmental Review Criteria}

Future noxious weed management activities proposed under the Region 7 Plan shall be reviewed in accordance with the following Environmental Review Criteria. In some cases, proposed activities may be determined by the DFWP to be categorically excluded from further environmental review. Those weed management activities for which the answer to every question below is "yes" are categorically excluded from subsequent review and can proceed under the current documentation. Activities triggering a "no" response to any of the questions below would prompt one of the following:

1) modification of the proposed activity to return it within the scope of the environmental analysis contained in this document.

2) rejection of the proposed activity outright.

3) initiation of a separate environmental review process for the proposed activity.

\section{DESCRIPTION OF THE PROPOSED ACTIVITY:}

\begin{tabular}{|l|l|l|}
\hline \multicolumn{1}{|c|}{ ENVIRONMENTAL REVIEW CRITERIA } & YES & NO \\
\hline $\begin{array}{l}\text { Will the weed management activity be conducted using principles of good } \\
\text { judgement? }\end{array}$ & & \\
\hline $\begin{array}{l}\text { Will the application of non-aquatic-labelled herbicides to running or standing } \\
\text { water be avoided? }\end{array}$ & & \\
\hline $\begin{array}{l}\text { Will surfaced waters be buffered from the introduction of excessive amounts } \\
\text { of sediment as a result of weed treatment activities? }\end{array}$ & & \\
\hline $\begin{array}{l}\text { Will herbicides be mixed and loaded at least } 500 \text { feet away from open water? } \\
\text { Will wick applicators be used when applying non-aquatic-labelled herbicides } \\
\text { within } 50 \text { feet of surface waters? }\end{array}$ & & \\
\hline $\begin{array}{l}\text { Will aquatic-labelled herbicides be selected for areas with a sandy or gravelly } \\
\text { soil consistency and for areas with water tables within } 3 \text { feet? }\end{array}$ & & \\
\hline
\end{tabular}


Will herbicide applications be avoided within 50 feet of high human use areas?

Will herbicide treatment sites be posted prior to and for 24 hours after herbicide application to notify the public that spraying activities will/have occurred?

Will the use of mechanized power equipment (e.g. mowers) be postponed when treatment sites are occupied by the public?

Will herbicide manufacturer label instructions be followed at all times?

Will herbicides be applied by licensed applicators?

Will aerial herbicide applications be avoided?

Will herbicide applications be suspended when rainfall is expected within 24 hours, air temperatures exceed $85^{\circ} \mathrm{F}$, or wind speed exceeds $8 \mathrm{~m}$. .p.h.?

Will herbicide spray equipment deliver a median drop diameter between 200 microns and 800 microns?

Is an Herbicide Emergency Response Plan in place?

Are biological control agents approved for release by the Animal and Plant Health Inspection Service?

Will riparian vegetation and surface water banks be protected from excessive disturbance resulting from weed management activity?

Will adverse impacts to rare, unique, threatened or endangered species resulting from weed treatment activities be avoided?

Will wildlife habitat be protected from excessive deterioration or disturbance during weed treatment activities?

Will Department personnel consider the impact of a weed treatment activity on wildlife populations, diversity, and distribution?

Will cultural/historic resources be protected from physical damage during weed treatment activities? 


\subsection{SUMMARY}

Exotic (non-native) weedy plants have been noted in Montana throughout this century. In the past few decades, some species have become significant components of local vegetation communities, actually dominating some sites. The most competitive and aggressive species have been termed "noxious." The Montana Legislature passed the County Noxious Weed Control Act in 1979, making it unlawful for a landowner to permit any noxious weed to propagate or go to seed on his/her land. This legislation also declared 15 non-native plant species as "noxious" and gave counties the authority to add species to the list as was locally necessary. Landowners are, by law, in compliance if a weed management plan has been prepared.

As a landowner of approximately 18,000 acres in southeast Montana, the DFWP, Region 7 , is required by local ordinances and state law to manage noxious weeds on its properties. Beyond the legal requirement, it is the mission of the DFWP to "...provide for the stewardship of the fish, wildlife, parks, and recreational resources of Montana, while contributing to the quality of life for the present and future generations." Part of being a responsible steward of land resources involves the treatment of noxious weeds. The DFWP (Region 7) prepared a noxious weed management plan which outlines an integrated approach to noxious weed management. The goal is the long-term reduction of noxious weeds. It will be achieved using a variety of methods (including manual, cultural, biological, and chemical) in which a particular technique is matched with the treatment needs of a specific weed population, while considering and protecting the integrity of all resource values on a particular site.

In accordance with the MEPA, the DFWP must examine and identify potential impacts of its actions on the natural and human environment. This draft EA describes the direct, indirect, and cumulative effects of the proposed implementation of the Plan. The EA also presents Alternatives to the implementation of the Plan and describes potential impacts of these Alternatives. The Alternatives are:

Alternative 1 (Status Quo): noxious weed management activities would continue over the course set since passage of the County Noxious Weed Control Act, namely chemical treatments without any particular safeguards beyond those indicated in the manufacturer label instructions. Biological, manual, and cultural methods were also employed to a certain degree. However, no particular effort was made to plan or coordinate weed management efforts with other resource programs. This Alternative does not incorporate provisions for other resource values. 
Alternative 2 (Integrated Noxious Weed Management): implementation of the Noxious Weed Management Plan which describes an approach integrating the management of noxious weeds with site resource values to achieve adequate weed management without negatively affecting other resources. Treatment methods would include manual, chemical, biological, and cultural.

Alternative 3 (Chemical Methods): emphasis on chemical treatment methods for all noxious weed management actions. No other methods would be used, with the exception of those biological control agents already introduced.

Alternative 4 (Non-Chemical Methods): emphasis on manual, cultural, and biological treatment methods for all noxious weed management actions. No chemical methods would be considered.

The preferred Alternative is 2, which would implement the Plan. .Potential impacts to the natural and human environments are evaluated. Resources considered during the evaluation were:
air quality
soils and geology
groundwater
surface water
fish and wildlife
vegetation
recreation
human health
cultural/historic resources

Table 12 summarizes and compares potential impacts resulting from each Alternative. 



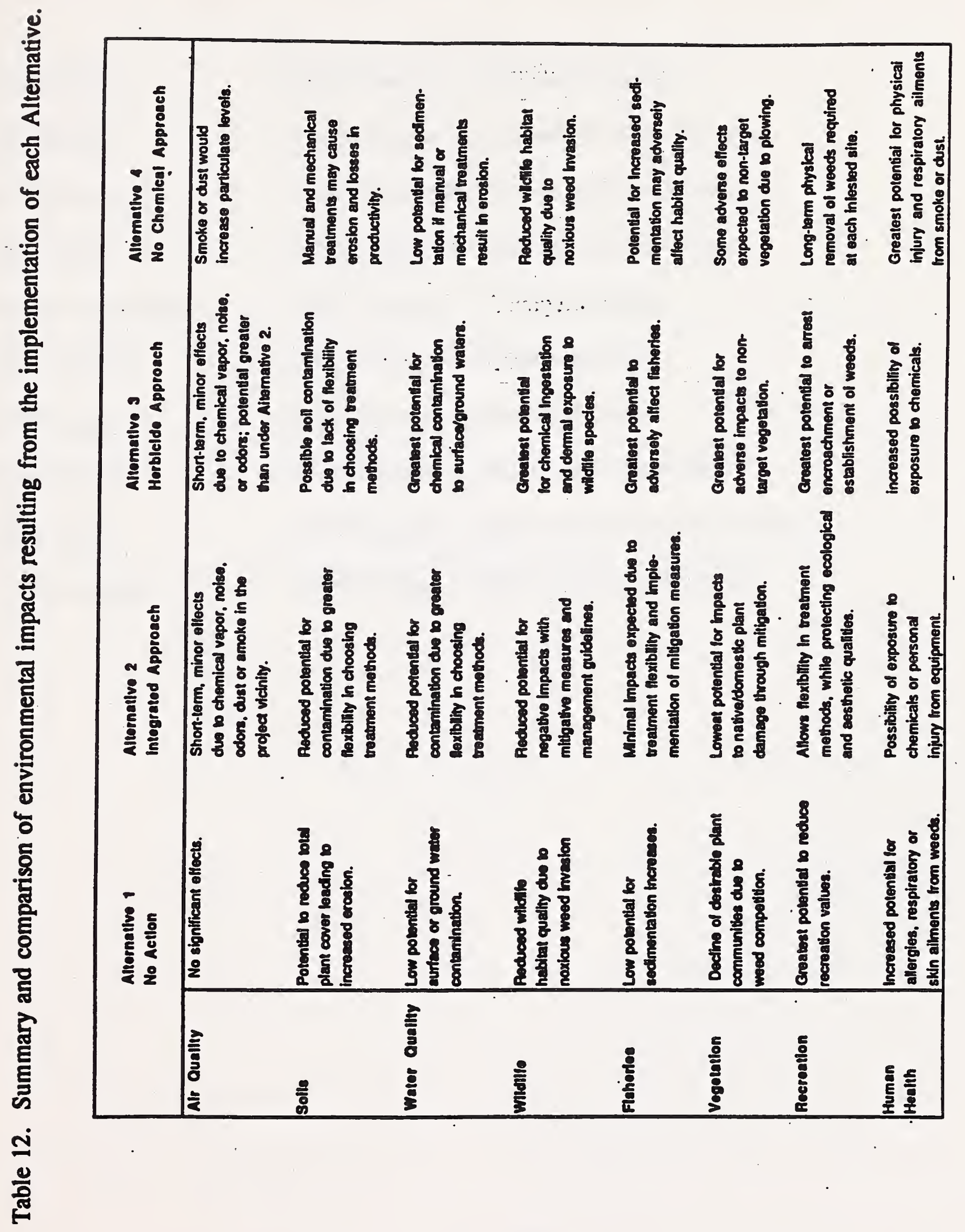





\subsection{LIST OF CONTRIBUTORS AND REVIEWERS}

Don Hyyppa

Neil Martin

Phil Stewart

John Little

Bernie Hildebrand

Scott Denson

John Ensign

Mike Backes

Jerry Dean

Mike Hathaway
DFWP Region 7, Regional Supervisor

DFWP Region 7, Regional Wildlife Manager

DFWP Region 7, Regional Fisheries Manager

DFWP Region 7, Regional Parks Manager

DFWP Region 7, Wildlife Biologist

DFWP Region 7, Wildlife Biologist

DFWP Region 7, Wildlife Biologist

DFWP Region 7, Conservation Specialist

DFWP Region 7, Parks Maintenance Supervisor

DFWP Region 7, Park Operations Specialist 



\subsection{REFERENCES}

Achuff, P.L. and L. A. Schassberger. 1991. Weeds and rare native plants. Symposium, Montana Academy of Sciences. Billings, Montana. Audus, L.J. 1976. Herbicides, physiology, biochemistry, ecology. Editor. Second edition, vol. 2. Academic Press, Inc. London, England.

Beaverhead National Forest. 1987. Environmental impact statement for noxious weeds and poisonous plant control. U.S. Department of Agriculture, Beaverhead National Forest. Dillon, Montana. 58pp. + appendices.

Bergeron, D.C., C. Jones, D.L. Genter, and D. Sullivan. 1992: P.D. Skaar's Montana bird distribution, fourth edition. Special Publication, No. 2. Montana Natural Heritage Program, Helena. 116pp.

Bureau of Land Management. 1985. Proposed Northwest Area noxious weed control program final environmental impact statement. U.S. Department of the Interior, Bureau of Land Management. Oregon State Office, Portland.

Bureau of Land Management. 1987. Supplement to the Northwest Area noxious weed control program final environmental impact statement. U.S. Department of the Interior, Bureau of Land Management. Oregon State Office, Portland.

Colby, S.R., E.R. Hill, N.E. Humburg, L.M. Kitchen, R.G. Lym, W.J. McAvoy, and R. Prasad. 1989. Herbicide handbook. 6th edition. Weed Science Society of America. Champaign, Illinois.

Deluca, T., J. Larson, L. Torma, and G. Algard. 1989. A survey of pesticide residues in ground in Montana. Montana Department of Agriculture, Environmental Management Division. Helena, Montana.

Elser, A.A., M.W. Gorges and L.M. Morris. 1980. Distribution of Fishes in Southeastern Montana. Montana Department of Fish, Wildlife and Parks, U.S. Department of the Interior, Bureau of Land Management. 136pp.

Environmental Protection Agency. 1983, 1986, and 1988. Pesticide fact sheets: 2,4-D, picloram, metsulfuron, and dicamba.

Environmental Protection Agency. 1986. Quality criteria for water with updates (Gold Book). Publication 44015-86-001.

Environmental Protection Agency. 1990. Office of Drinking Water. Drinking water regulations and health advisories. 
Evans, J.O. and D. Dvseja. 1973. Herbicide contamination of surface runoff water. Utah State University, Logan. Office of Research and Monitoring, U.S. Environmental Protection Agency, Washington, D.C. EPA-R2-73-266. 99pp.

Gallatin National Forest. 1987. Noxious weed control final environmental impact statement. U.S. Department of Agriculture, Gallatin National Forest. Bozeman, Montana. 35pp. + appendices.

Holton, G.D. 1990. A field guide to Montana fishes. Montana Department of Fish, Wildlife and Parks. 104pp.

Lacey, C. 1991. Groundwater and agrichemical protection pilot project. Unpublished report and maps prepared for Lewis \& Clark County Conservation District.

Lavelle, D. 1988. Use and preference of spotted knapweed by elk and mule deer on two winter ranges in western Montana. Master's thesis, University of Montana, Missoula. 64pp.

Lessica, P. 1993. Botanist. Personal communications with Carolyn Sime, Montana Department of Fish, Wildlife and Parks.

Lessica, P. and J.S. Shelly. 1991. The effect of the introduced weed (Centaurea maculosa) on Arabis fecunda, a threatened Montana endemic. Unpubl. report. Montana Natural Heritage Program, Helena. 19pp. + appendices.

Levine, C. 1993. Ecosystems Management Section, Water Quality Bureau, Montana Department of Health and Environmental Sciences. Personal communications with Carolyn Sime, Montana Department of Fish, Wildlife and Parks.

Linnainmaa, K. 1983. Non-mutagenicity of phenoxy acid herbicides 2,4-dichlorophenoxyacetic acid [2,4-D] and 4-methyl-2-chlorophenoxyacetic acid [MCPA]. Pages 385-395 in Choudhary et al. Chlorinated dioxins and dibenzofurans in the total environment. Butterworth Publishers. Woburn, Massachusetts.

Littlefield, J. 1993. Insect Quarantine Lab, campus of Montana State University. Personal communications with Carolyn Sime, Montana Department of Fish, Wildlife and Parks.

Lolo National Forest. 1989. Noxious weed management draft environmental impact statement, amendment to the Lolo National Forest Plan. U.S. Department of Agriculture, Lolo National Forest. Missoula, Montana. 
Lolo National Forest. 1991. Noxious weed management final environmental impact statement, amendment to the Lolo National Forest Plan. U.S. Department of Agriculture, Lolo National Forest. Missoula, Montana.

McKenna, D. 1993. Associate Research Hydrogeologist, Montana Bureau of Mines and Geology. Personal communications with Carolyn Sime, Montana Department of Fish, Wildlife and Parks.

Monnig, E. 1988. Human health risk assessment of herbicide applications to control noxious weeds and poisonous plants in the Northern Region. U.S. Department of Agriculture Forest Service, Northern Region RPT 88-9. Missoula, Montana. 218pp.

Montagne, C., L.S. Munn, G.A. Nielsen, J.W. Rodgers, and H.E. Hunter. 1982. Soils of Montana. Montana Agriculture Experiment Station Bulletin 744, Montana State University, Bozeman. 95pp.

Montana Bald Eagle Working Group. 1991. Habitat management guide for bald eagles in northwestern Montana. 29pp.

Montana Department of Agriculture. 1991. Draft noxious weed trust fund programmatic environmental impact statement. Helena, Montana.

Montana Department of Fish, Wildlife and Parks. 1983. Weed control program for lands managed by the Montana Department of Fish, Wildlife and Parks. 4pp.

Montana Department of Fish, Wildlife and Parks. 1992. Creating a Vision for the Future. Helena, Montana.

Montana Department of Fish, Wildlife and Parks. 1993. Draft weed management plan for Region 2. Prepared by Land and Water Consulting Inc. Missoula, Montana. 34pp. + appendices.

Montana Department of Fish, Wildlife and Parks. 1993. Draft environmental analysis for weed management for Region 2. Prepared by Land and Water Consulting Inc. Missoula, Montana. 29pp. + appendices.

Montana Department of Fish, Wildlife and Parks. 1993. Draft integrated noxious weed management plan for Region 8. Prepared by OEA Research Inc. Helena, Montana. 78pp. + appendices.

Montana Department of Fish Wildlife and Parks. 1993. Draft environmental assessment of the integrated noxious weed management plan for Region 8. Prepared by OEA Research Inc. Helena, Montana. 56pp. + appendices. 
Montana Department of Fish, Wildlife and Parks. 1994. Draft noxious weed management plan, Region 3. Montana Department of Fish, Wildlife and Parks, Bozeman. 78pp. + appendices.

Montana Department of Fish Wildlife and Parks. 1993. Draft environmental assessment of the integrated noxious weed management plan for Region 3. Montana Department of Fish, Wildlife and Parks Bozeman, Montana. 63pp. + appendices.

Montana Department of Fish, Wildlife and Parks. 1994. Draft noxious weed management plan, Region 1. Montana Department of Fish, Wildlife and Parks, Kalispell, Montana 59pp. + appendices.

Montana Department of Fish Wildlife and Parks. 1994. Draft environmental assessment of the integrated noxious weed management plan for Region 1. Montana Department of Fish, Wildlife and Parks, Kalispell, Montana. 61pp. + appendices.

Montana Department of Fish, Wildlife and Parks. 1996. Draft noxious weed management plan, Region 7. Montana Department of Fish, Wildlife and Parks, Miles City, Montana 76 pp. + appendices.

Montana Department of Health and Environmental Sciences. 1992. Montana water quality: the Montana 305(b) report. Ecosystems Management Section, Water Quality Bureau, Environmental Sciences Division. 42pp.

Montana Natural Heritage Program. 1995. Database search for Species of Special Concern and threatened/endangered species in the vicinity of Montana Department of Fish, Wildlife and Parks properties in Region 7.

National Research Council of Canada. 1977. Picloram: the effects of its use as a herbicide on environmental quality. Pages 34-36 in NRCC No. 13684. Associated Committee on Scientific Criteria for Environmental Quality. Quebec, Canada.

Nelson, J., D. Wichman, P. Fay, and J. Connor. 1990. Montana weed control guide. Montana State University Extension Publication EB-23. Bozeman, Montana. 113pp.

O'Brien, M. 1990. Roundup, Vision, POEA, and 1,4,dioxane: why full formulations are the problem. Journal of Pesticide Reform 9(4):14-15.

Pence, D. 1993. Beaverhead National Forest. Personal communications with Carolyn Sime, Department of Fish, Wildlife and Parks.

Phillips, G. 1993. Pollution Control Biologist and Water Quality Specialist for the Montana Department of Fish, Wildlife and Parks. Personal communications with Carolyn Sime, Montana Department of Fish, Wildlife and Parks. 
Rice, P.M., D.J. Bedunah, C.E. Carlson. 1992. Plant community diversity after herbicide control of spotted knapweed. U.S. Department of Agriculture Forest Service Intermountain Forest and Range Experiment Station. Research paper INT 460. Ogden, Utah. 6pp.

Sassman, J., R. Pienta, M. Jacobs and J. Cioffi. 1984. Pesticide background statements. Volume 1, herbicides. Agriculture Handbook No. 633. U.S. Government Printing Office. Washington, D.C.

Smith, Mark. 1993. Ecosystems Management Section, Water Quality Bureau, Montana Department of Health and Environmental Sciences. Personal communications with Carolyn Sime, Montana Department of Fish, Wildlife and Parks.

Soucek, P. 1993. Gallatin National Forest. Personal communications with Carolyn Sime, Department of Fish, Wildlife and Parks.

Sparks, D.L. 1989. Kinetics of soil chemical processes. Academic Press, Inc. San Diego, California.

Story, J. 1989. Biological control: its potential for progress toward knapweed control in the next 10 years. Pages 237-238 in P.K. Fay and J.R. Lacey, editors. Proceedings of the 1989 knapweed symposium. Montana State University, Bozeman.

Thompson, L. 1982. Distribution of Montana amphibians, reptiles, and mammals. Montana Audubon Council. Helena, Montana. 24pp.

Tosine, H. 1983. Dioxins: a Canadian perspective. Pages 3-14 in Choudhary et al. Chlorinated dioxins and dibenzofurans in the total environment. Butterworth Publishers. Woburn, Massachusetts.

U.S. Department of Agriculture. 1984. Pesticide background statements. Volume 1, herbicides. Agricultural Handbook 633. Washington, D.C.

U.S. Department of Agriculture. 1988. Draft environmental impact statement for vegetation management in the Coastal Plain/Piedmont. Management Bulletin R8-MB 15. Southern Region, Atlanta, Georgia.

U.S. Fish and Wildlife Service. 1980. Handbook of acute toxicity of chemicals to fish and aquatic invertebrates. Resource Publication No. 137. U.S. Department of the Interior, Fish and Wildlife Service. Washington, D.C.

Watson, V.J., P.M. Rice, and E.C. Monnig. 1989. Environmental fate of picloram used for roadside weed control. Journal of Environmental Quality 18(2):198-205. 
Workman, D. 1992. Fisheries Manager, Montana Department of Fish, Wildlife and Parks. Personal communications with OEA Research Inc. 


\subsection{APPENDICES}

APPENDIX A Herbicide Properties and Efficacy on Target Noxious Weed Species

APPENDIX B Fish and Wildlife Species Known to Occur in Region 7 of the Montana Department of Fish, Wildlife and Parks 



\section{APPENDIX A}

HERBICIDE EFFICACY ON STATE-DECLARED NOXIOUS WEED SPECIES

PROPERTIES OF COMMONLY USED HERBICIDES 



\section{Herbicide Efficacy on State-Declared Noxious Weed Species}

\begin{tabular}{|c|c|c|c|c|}
\hline \multicolumn{5}{|c|}{ Efficacy Rating" } \\
\hline Excellent & Good & Far & Poor & $\begin{array}{l}\text { Insufficlent } \\
\text { data }\end{array}$ \\
\hline
\end{tabular}

\section{Category 1}

Canada thistle

Dalmatian toadilax

D.P,C

G

Field bindweed

-

Leafy spurge

Diffuse knapweed

Russian knapweed

Spotted knapweed

St. Johnswort (goatweed)

- D,P,G,2

Whitetop (hoary cress)

2, D

2,D,P

$P$

D,P,G,C

-

D,P,G,C

$\bar{P}$

$P$

Category 2

Dyers woad

Purple loosestrite

Sulfur cinquefoil

$\begin{array}{ll}\text { D** } & 2, P, G \\ G & 2, D \\ D, P, G & 2\end{array}$

Category 3

: Rush skeletomweed P

P D

D

Yellow stanthistle

Common crupina

- Control ratings for the herbicides are as follows:

Excellent $=>95 \%$ of weed population killed by single treatment

Good= one treatment per year maintains $85-94 \%$ suppression

Fair $=60-84 \%$ of weed popuiation killed by single treatment

Poor $=10-59 \%$ of weed population killed by single treatment

Insufficient data $=$ insufficient data exists to determine effectiveness

- C-clopyralid, D-dicamba, G=glyphosate, P=plicioram, A=metsulturon, M=MCPA, 2=2,4-D

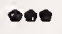

Data sources confilict on 2,4-D efficacy for spotted knapweed; Data ranges from poor to excellent.

References: USDI-Bureau of Land Management 1985; Nelson et al 1990; McCone 1991; Johnson 1991. 


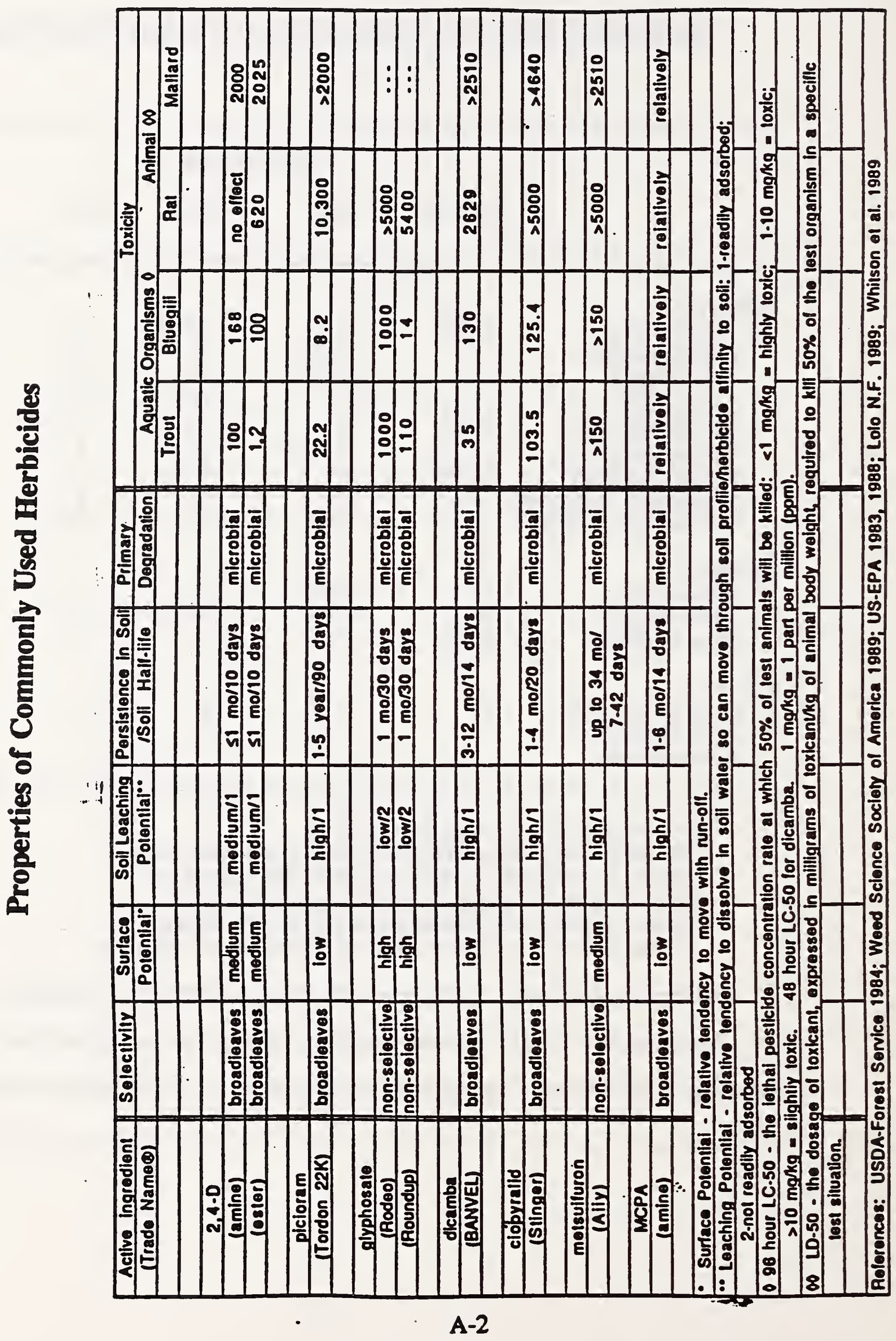




\section{APPENDIX B}

FISH AND WILDLIFE SPECIES RECORDED IN LATILONGS CORRESPONDING WITH DEPARTMENT OF FISH, WILDLIFE AND PARKS REGION 7. 

Bird Species recorded in latilongs $21,22,23,24,32,33,34,35,43,44 \& 45$. This list is based on the species and sequence from Montana Bird Distribution, 4th edition, published in 1992 by the Montana Audubon Council and the Montana Natural Heritage Program.

Common loon

Pied-billed grebe

Horned grebe

Red-necked grebe

Eared grebe

Western grebe

Clark's grebe

American white pelican

Double-crested cormorant

American bittern

Least bitterns

Great blue heron

Great egret

Snowy egret

Cattle egret

Little blue heron

Green-backed heron

Black-crowned night-heron

White-faced ibis

Wood stork

Tundra swan

Trumpeter swan

Greater white-fronted goose

Snow goose

Ross' goose

Brant

Canada goose

Wood duck

Green-winged teal

American black duck

Mallard

Northern pintail

Blue-winged teal

Cinnamon teal

Northern shoveler

Gadwall

American widgeon

Canvasback

Redhead

Ring-necked duck

Great scaup
Lesser scaup

Harlequin duck

Oldsquaw

Surf scoter

Common goldeneye

Barrow's goldeneye

Bufflehead

Hooded merganser

Common merganser

Red-breasted merganser

Ruddy duck

Turkey vulture

Osprey

Bald eagle

Northern harrier

Sharp-shinned hawk

Cooper's hawk

Northern goshawk

Broad-winged hawk

Swainson's hawk

Red-tailed hawk

Ferruginous hawk

Rough-legged hawk

Golden eagle

American sestrel

Merlin

Peregrine falcon

Gyrfalcon

Prairie falcon

Gray partridge

Chukar

Ring-necked pheasant

Spruce grouse

Ruffed grouse

Sage grouse

Sharp-tailed grouse

Wild turkey

Virginia rail

Sore

American coot

Sandhill crane 
Whooping crane

Black-bellied plover

Lesser golden-plover

Snowy plover

Semipalmated plover

Piping plover

Killdeer

Mountain plover

Black-necked stilt

American avocet

Greater yellowleg

Lesser yellowleg

Solitary sandpiper

Willet

Spotted sandpiper

Upland sandpiper

Whimbrel

Long-billed curlew

Hudsonian godwit

Marbled godwit

Ruddy turnstone

Red knot

Sanderling

Semipalmated sandpiper

Western sandpiper

Least sandpiper

White-rumped sandpiper

Baird's sandpiper

Pectoral sandpiper

Dunlin

Stilt sandpiper

Buff-breasted sandpiper

Short-billed dowitcher

Long-billed dowitcher

Common snipe

Wilson's phalarope

Red-necked phalarope

Pomarine jaeger

Franklin's gull

Bonaparte's gull

Ringed-billed gull

California gull

Herring gull

Glaucous gull

Sabine's gull

Caspian tern
Common tern

Forster's tern

Least tern

Black tern

Rock dove

Mourning dove

Black-billed cuckoo

Yellow-billed cuckoo

Common barn-owl

Eastern screech-owl

Great horned owl

Snowy owl

Northern pygmy-owl

Burrowing owl

Long-eared owl

Short-eared owl

Northern saw-whet owl

Common nighthawk

Common poorwill

Chimney swift

White-throated swift

Calliope hummingbird

Belted kingfisher

Lewis' woodpecker

Red-headed woodpecker

Yellow-bellied sapsucker

Red-naped sapsucker

Downy woodpecker

Hairy woodpecker

Black-backed woodpecker

Northern flicker

Olive-sided flycatcher

Western wood-pewee

Eastern wood-pewee

Willow flycatcher

Least flycatcher

Hammond's flycatcher

Dusky flycatcher

Eastern phoebe

Say's phoebe

Great crested flycatcher

Cassin's kingbird

Western kingbird

Eastern kingbird

Horned lark

Purple martin 
Tree swallow

Violet-green swallow

Northern rough-winged swallow

Bank swallow

Cliff swallow

Barn swallow

Steller's jay

Blue jay

Pinyon jay

Clark's nutcracker

Black-billed magpie

American crow

Common raven

Black-capped chickadee

Mountain chickadee

Red-breasted nuthatch

White-breasted nuthatch

Pygmy nuthatch

Brown creeper

Rock wren

Canyon wren

House wren

Winter wren

Sedge wren

Marsh wren

Golden-crowned kinglet

Ruby-crowned kinglet

Eastern bluebird

Mountain bluebird

Townsend's solitaire

Veery

Gray-cheeked thrush

Swainson's thrush

Hermit thrush

Wood thrush

American robin

Gray catbird

Northern mockingbird

Sage thrasher

Brown thrasher

American pipit

Spraque's pipit

Bohemian waxwing

Cedar waxwing

Northern shrike

Loggerhead shrike
European starling

Solitary vireo

Warbling vireo

Red-eyed vireo

Tennessee warbler

Orange-Crowned warbler

Nashville warbler

Northern parula

Yellow warbler

Magnolia warbler

Cape may warbler

Black-throated blue warbler

Yellow-rumped warbler

Townsend's warbler

Palm warbler

Blackpoll warbler

Black-and-white warbler

American redstart

Ovenbird

Northern waterthrush

MacGillivray's warbler

Common yellowthroat

Wilson's warbler

Yellow-breasted chat

Western tanager

Rose-breasted grosbeak

Black-headed grosbeak

Lazuli bunting

Indigo bunting

Green-tailed towhee

Rufous-sided towhee

American tree sparrow

Chipping sparrow

Clay-colored sparrow

Brewer's sparrow

Field sparrow

Vesper sparrow

Lark sparrow

Sage sparrow

Lark bunting

Savannah sparrow

Baird's sparrow

Grasshopper sparrow

LeConte's sparrow

Fox sparrow

Song sparrow 
Lincoln's sparrow

Swamp sparrow

White-throated sparrow

White-crowned sparrow

Harris' sparrow

Dark-eyed junco

McCown's longspur

Lapland longspur

Smith's longspur

Chestnut-collared longspur

Snow bunting

Bobolink

Red-winged blackbird

Western meadowlark

Yellow-headed blackbird

Rusty blackbird

Breer's blackbird

Common grackle

Brown-headed cowbird

Orchard oriole

Northern oriole

Rosy finch

Pine grosbeak

Purple finch

Cassin's finch

House finch

Red crossbill

White-winged crossbill

Common redpoll

Hoary redpoll

Pine siskin

American goldfinch

Evening grosbeak

House sparrow 
Fish species known to occur in southeast Montana. This list is based on Distribution of Fishes in Southeastern Montana. by Elser, A.A., M.W. Gorges and L.M. Morris, 1980. Montana Department of Fish, Wildlife and Parks, U.S. Bureau of Land Management. 136pp.

Pallid sturgeon

Paddlefish

Mountain whitefish

Brown trout

Rainbow smelt

Carp

Golden shiner

Northern redbelly dace

Sturgeon chub

Emerald shiner

Brassy minnow

Wester silvery minnow

Longnose dace

Blue sucker

Shortnose redhorse

White sucker

Black bullhead

Channel catfish

Burbot

Mosquitofish

White bass

Green sunfish

Bluegill

Largemouth bass

Black crappie

Sauger

Iowa darter
Shovelnose sturgeon

Goldeye

Rainbow trout

Brook trout

Northern pike

Goldfish

Creek chub

Flathead chub

Lake chub

Sand shiner

Plains minnow

Fathead minnow

River carpsucker

Smallmouth buffalo

Longnose sucker

Mountain sucker

Yellow bullhead

Stonecat

Plains killifish

Brook stickleback

Rock bass

Pumpkinseed

Smallmouth bass

White crappie

Yellow perch

Walleye

Freshwater drum 
Amphibian, reptile and mammal species recorded in latilongs 36, 37, 38, 39, 46, and 47. These lists are based on Distribution of Montana Amphibians, Reptiles, and Mammals by Larry S. Thompson, published in 1982 by The Montana Audubon Council.

\section{AMPHIBIANS}

Tiger salamander

Long-toed salamander

Tailed frog

Plains spadefoot
Boreal (western) toad Boreal chorus frog Spotted frog Leopard frog

\section{REPTILES}

Snapping turtle

Painted turtle

Spiny softshell turtle

Eastern short-horned lizard

Northern sagebrush lizard

Rubber boa
Racer

Bull snake

Western spiny softshell turtle Common garter snake Western garter snake Prairie rattlesnake 
Masked shrew

Merriam shrew

Little brown myotis

Yuma myotis

Long-eared myotis

Silver-haired bat

Big brown bat

Hoary bat

Black bear

Raccoon

Shorttail weasel

Least weasel

Longtail weasel

Mink

River otter

Badger

Striped skunk

Coyote

Red fox

Swift fox

Mountain lion

Bobcat

Yellowbelly marmot

Blacktail prairie dog

Richardson ground squirrel

Thirteen-lined ground squirrel

Least chipmunk

Eastern gray squirrel
Eastern fox squirrel

Red squirrel

Northern pocket gopher

Wyoming pocket mouse

Ord kangaroo rat

Beaver

Western harvest mouse

White-footed mouse

Deer mouse

Northern grasshopper Mouse

Bushytail woodrat

Meadow vole

Prairie vole

Longtail vole

Sagebrush vole

Muskrat

Meadow jumping mouse

Porcupine

Whitetail jackrabbit

Mountain cottontail

Eastern cottontail

Desert cottontail

Elk

Mule deer

Whitetail deer

Pronghorn antelope

Bison

Bighorn sheep 

